\author{
UNIVERSIDADE DE SÃO PAULO \\ FACULDADE DE FILOSOFIA, LETRAS E CIÊNCIAS \\ HUMANAS \\ DEPARTAMENTO DE FILOSOFIA \\ PROGRAMA DE PÓS-GRADUAÇÃO EM FILOSOFIA
}

FIM DO ETHOS ANTIGO E OCASO DAS ILUSÕES:

GIACOMO LEOPARDI E A MODERNIDADE

Fábio Rocha Teixeira 


\author{
UNIVERSIDADE DE SÃO PAULO \\ FACULDADE DE FILOSOFIA, LETRAS E CIÊNCIAS \\ HUMANAS \\ DEPARTAMENTO DE FILOSOFIA \\ PROGRAMA DE PÓS-GRADUAÇÃO EM FILOSOFIA
}

\title{
FIM DO ETHOS ANTIGO E OCASO DAS ILUSÕES: GIACOMO LEOPARDI E A MODERNIDADE
}

Fábio Rocha Teixeira

\begin{abstract}
Tese apresentada ao Programa de Pós-graduação do Departamento de Filosofia, Letras e Ciências Humanas da Universidade de São Paulo, como requisito parcial para a obtenção do título de Doutor em Filosofia.
\end{abstract}

Orientadora: Profạ. Dra. Olgária Chain Feres Matos 


\section{Fábio Rocha Teixeira}

Fim do Ethos Antigo e Ocaso das ilusões: Giacomo Leopardi e

\section{a Modernidade}

Tese apresentada ao Programa de Pós-graduação do Departamento de Filosofia, Letras e Ciências Humanas da Universidade de São Paulo, como requisito parcial para a obtenção do título de Doutor em Filosofia.

COMISSÃO EXAMINADORA

Prof ${ }^{a}$. Drª . Olgária Chain Féres Matos

Orientadora

Depto. de Filosofia - FFLCH - USP

Profa ${ }^{-}$. Drª Maria das Graças

Depto. de Filosofia - FFLCH - USP

Prof. Dra Jacira de Freitas

Depto. de Filosofia - Humanidades - UNIFESP

Prof. Dr. Expedito Passos Lima

Depto. Filosofia - Centro de Humanidades - UECE

Prof. Dr. Marco Americo Lucchesi

Depto. Pós-graduação em Letras neolatinas - UFRJ 


\section{AGRADECIMENTOS}

De início, gostaria de agradecer à Professora Olgária Matos por ter acolhido com coragem a proposta deste trabalho. De tantos anos de acompanhamento na árdua tarefa de realizar esta pesquisa, além da perspicácia de suas observações e sugestões, o que permanece é a lição de vida, em tornar prática cotidiana a gentileza e a leveza ante as solicitações do peso do mundo. Inspiração! Um "elogio dos Pássaros" leopardiano para Olgária. Muito obrigado por todos os ensinamentos que ultrapassam os muros da Academia. Ao Professor Expedito Passos agradeço pelas orientações ao longo desses anos, pelo exemplo de profissional e pessoa humana, por ter me iniciado nos estudos leopardianos e me fazer acreditar na possibilidade de tornar nossa curta caminhada pela vida menos sofrível. Quais palavras satisfariam a necessidade de agradecer a quem se deve muito? Quem sabe, solitária, Gratidão! Espero um dia the dar orgulho, meu Professor e amigo! À Professora Maria das Graças agradeço pelas sugestões e indagações acerca desta pesquisa em minha banca de qualificação. Pelo carinho, simpatia e serenidade expressos desde sempre no convívio, meu respeito e admiração! Ao professor Mario Andrea Rigoni, agradeço pela recepção de minha solicitação de pesquisa na Itália, experiência que me foi de suma importância para melhor compreender a sábia mensagem do pensamento de Leopardi. Aos meus familiares agradeço a paciência e compreensão por esses anos de minha ausência. Às meninas da Secretária o meu muito obrigado pelas informações e auxílios prestados durante todos esses anos de estudo. Também pelas muitas risadas que ajudam a descontrair e clarear a mente. Ao Fernando e à Tatiana agradeço pelo apoio e convivência por toda a minha estadia na Residência Universitaria da USP. Pelo carinho que permanece recíproco! Agradeço ainda à FAPESP por financiar esta pesquisa no Brasil e à CAPES pelo financiamento de meu estágio no exterior, sem os quais este trabalho seria irrealizável. Muito obrigado a todos, por me permitirem aprender com vocês! 


\section{Ficha Catalográfica}

Teixeira Rocha, Fábio

Fim do Ethos Antigo e Ocaso das ilusões: Giacomo Leopardi e a Modernidade/ Fábio Rocha Teixeira; orientadora: Olgária Chain Féres Matos. - São Paulo: USP - Departamento de Filosofia, 2012.

V, 227 f.: 53ils.; $30 \mathrm{~cm}$

Tese (doutorado) - Universidade de São Paulo - Departamento de Filosofia.

Inclui referências bibliográficas.

1. Mundo antigo 2. Modernização 3. Ilusões 4. Razão 5. Barbárie

I. Matos, Olgária. II. Universidade de São Paulo. III. Departamento de Filosofia. 
Sono condannati alla infelicità dalla natura, e non dagli uomini nè dal caso: e per conforto di questa infelicità inevitabile mi pare che vagliano sopra ogni cosa gli studi del belo, gli affetti, le immaginazioni, le illusioni. Così avviene che il dilettevole mi pare utile sopra tutti gli utili, e la letteratura utile più veramente e certamente di tutte queste discipline secchissime [la política, la statistica, ecc.]; le quali anche ottenendo i loro fini, gioverebbero pochissimo alla felicità vera degli uomini, che sono individui e non popoli; ma quando poi gli ottengono questi loro fini? Amerò che me lo insegni un de' nostri professori de scienze storiche.

Giacomo Leopardi. Epistolario.

Noi non miriamo nè all'aumento dell'industria, nè al miglioramento degli ordini sociali, nè al perfezionamento dell'uomo. [...] II nostro scopo dunque non è giovare al mondo, ma dilettare quei pochi che leggeranno. Lasciamo stare che lo scopo finale d'ogni cosa utile essendo il piacere, il quale poi all'ultimo si ottiene rarissime volte, la nostra privata opinione è che il dilettevole sia più utile che l'utile. Noi abbiamo torto certamente, poiché il secolo crede il contrario. Ma in fine se nel gravissimo secolo decimono, [...] v'è ancora di quelli che vogliano leggere per diletto, [...] questi tali sottoscrivano alla nostra impresa.

Giacomo Leopardi. Prose.

não há dúvida de que os progressos da razão e o desaparecimento das ilusões produzem a barbárie, $e$ um povo demasiado iluminado não se torna muito civilizado, como sonham os filósofos do nosso tempo [...] mas bárbaro [...]. A maior inimiga da barbárie não é a razão, mas a natureza.

Giacomo Leopardi. Zibaldone di pensieri. 


\section{RESUMO}

Esta Tese tem como tema a problemática do fim do antigo ethos e o ocaso das ilusões no mundo moderno com base na reflexão de Giacomo Leopardi (17981837) sobre os seus efeitos nefastos. Tal reflexão considera também a problemática da barbárie moderna e pressupõe, igualmente, as formas anteriores da barbárie: a primitiva e a medieval. Na presente investigação não se retorna à questão da ideia de uma filosofia leopardiana ou de uma proposta de "sistema" no seu interior, pois não se trata, quer da antiga querela de um Leopardi "poeta ou filósofo" quer de uma exposição pormenorizada acerca de uma filosofia em Leopardi. Nesta investigação adotam-se as seguintes hipóteses interpretativas: i) o Discorso sopra lo stato presente dei costumi degl'italiani, escrito em 1824, contribui para uma compreensão da análise leopardiana acerca do processo de modernização europeia; ii) o Discorso pressupõe uma nova mudança no desenvolvimento da obra leopardiana, da nova crise ocorrida no seu pensamento em 1824, seguida da nova concepção de natureza, não mais aquela amorosa, mas uma natura matrigna, responsável por todos os males e a infelicidade humana; iii) Leopardi aborda elementos fundamentais das mudanças ocorridas no ethos após o processo de modernização europeu com base em um diagnóstico da situação econômica, social, cultural e política italiana; iv) no seu diagnóstico sobre a modernização, ele indica um novo princípio de conservação da vida civil; v) a experiência da modernização, por causa da nova forma de racionalidade e de espiritualização das coisas e do homem, põe em risco a vitalidade humana e conduz a uma nova barbárie: barbárie da sociedade. Ao investigar a experiência filosófica italiana dos séculos XVIII e XIX, Leopardi destaca os rumos tomados pela racionalidade e os riscos identificados por ele de uma barbárie dos novos tempos. Ele denomina o século XIX como "século de morte" em virtude do desaparecimento da dimensão poética e das "ilusões", tão necessárias à conservação da existência humana. Trata-se de uma critica aos novos fenômenos de banalização da vida no mundo moderno e de suas degenerescências: ruína das ilusões, vacuidade dos valores e risco da barbárie da sociedade.

PALAVRAS-CHAVE: mundo antigo, modernização, ilusões, razão, barbárie. 


\section{ABSTRACT}

The theme of this thesis is the end of the ancient ethos, the twilight of illusions in the modern world and its adverse effects based on the reflection of Giacomo Leopardi (1798-1837). Such reflection also considers the issue of modern barbarism and presupposes its earlier forms, namely, the primitive and medieval barbarism. This research does not investigate the idea of a Leopardi's philosophy nor the proposal of a "system" inside his philosophy. It does not approach the old quarrel over Leopardi as a "poet or as philosopher", nor a detailed exposition of philosophy in Leopardi's work. This research adopts the following interpretative hypotheses: i) the Discorso sopra lo stato presente dei costumi deglitaliani, written in 1824, contributes to the understanding of the Leopardi's interpretation of the European modernization process; ii) the Discorso presupposes a new change in the development of Leopardi's work, because of the new crisis in his thought in 1824, followed by a new conception of nature, which is no longer a loving one, but a natura matrigna, responsible for all evil and human misery; iii) Leopardi addresses the main economic, social, cultural and political changes in the Italian ethos after the European modernization process; iv) His diagnosis of modernization indicates a new principle of the conservation of civil life; $v$ ) the experience of modernization endangers human vitality and leads to a new barbarism, because of the new rationality and spiritualization of objects and man, namely, the barbarism of society. Leopardi emphasizes the new forms of rationality and their risks, a new era of barbarism, in his investigation of the philosophical experience of the Italian Eighteenth and Nineteenth centuries. He calls the Nineteenth century "the century of death" because of the disappearance of the poetic dimension and of the "illusions", that are so necessary for the preservation of human existence. This thesis focus a critique of the new phenomena of banalization of life in the modern world and its degeneracies, namely, the end of illusions, vacancy of values and the risk of the society barbarism.

KEYWORDS: ancient world, modernization, illusions, reason, barbarism. 


\section{ÍNDICE}

Introdução

Itália e modernidade europeia: reflexão leopardiana

I. Leopardi e os costumes dos italianos: abordagem da modernização no Discorso de 1824

1.1 A Itália e as outras nações europeias: a análise leopardiana

1.2 Società strette e vida civil na Itália e nas outras nações europeias.

1.3Modernização e vínculos civis: a especificidade italiana

1.4 Fragilidade dos vínculos civis modernos: frivolidade nos costumes na società stretta.

1.5 A diagnose leopardiana do presente: Leopardi filósofo social ou metafísico?

II. Civilização meridional e meridionalidade: a problemática leopardiana entre antigos e modernos

2.1 O mezzogiorno como universo cultural: a Itália e a sua recepção europeia.

2.2 Características naturais do meridione e setentrião: as formulações leopardianas.

2.3 Clima e disposições naturais: setentrionais e meridionais

2.4 Meridionais-setentrionais e Antigos-modernos: sobre a atividade da imaginação, a Filosofia e a vida civil.

2.5 A Itália e as outras nações civis europeias: barbárie e civilização

Modernidade e crítica leoparidiana à nova barbárie: negatividade dos tempos modernos.

III. Fim do antigo ethos e Modernidade: a reflexão leopardiana.

3.1 O renascer da civilização na Europa do século XV.

3.2 As luzes e o renascer da civilização.

3.3 Permanência das ilusões nas antigas repúblicas e a na monarquia......

3.4 Modernidade e processo de espiritualização das coisas humanas.

3.5 Ethos antigo e mundo moderno: a crítica poética leopardiana

3.6 Decadência da civilização e barbárie.

3.7 Ante o maquiavelismo de sociedade: chamar as coisas pelos nomes.... Conclusão 


\section{INTRODUÇÃO}

A presente investigação, ao retomar esta temática leopardiana -, pois se trata aqui de dar continuidade aos estudos iniciados na Dissertação de Mestrado sobre a obra de Giacomo Leopardi, a saber, A crítica à Modernidade em Giacomo Leopardi: em busca de uma ultrafilosofia ${ }^{1}$-, pressupõe a necessidade de esclarecer, em um primeiro momento, as premissas deste novo estudo. Se a pesquisa anterior buscou explicitar alguns elementos primários de certa problemática dos estudos leopardianos, a saber, "Leopardi filósofo ou poeta?" ${ }^{2}$, e a viragem filosófica de sua obra ocorrida em $1819^{3}$, aqui

1 Dissertação defendida em 2007, no Programa de Pós-Graduação do Departamento de Filosofia, Letras e Ciências Humanas da Universidade de São Paulo, sob a orientação da Professora Dra. Olgária C. F. Matos.

${ }^{2} \mathrm{Na}$ Introdução aos Pensieri leopardianos (1829-1835), Dino Basili comenta a afirmação de Sergio Solmi, de que "Leopardi é e não é filósofo". Basili sustenta que: a obra de Leopardi apresenta riqueza, profundidade e coerência especulativa, como herança iluminista fundamental. "Que não constitua um pensamento lógico e sistemático, é opinião largamente compartilhada pelos estudiosos". Igualmente, seja a busca incessante e original do homem e do seu destino, sejam as ramificações metafísicas "não conseguem e não consentem comprimir Leopardi na fileira [...] dos moralistas do seu século inquieto". Basili evita qualquer indagação que venha lançar Leopardi nas "armadilhas das etiquetas" [trappola delle etichette] acadêmicas ou da publicidade, e reconhece a complexidade da questão, em que se inscreve uma "dialética muito pessoal entre razão e sentimento, análise científica e intuição psicológica, rigor e relaxamento" (Cf. G. Leopardi, Introduzione, in: Pensieri [1829-1835]. Milano: Mondadori, 1993, pp. 14-15). Para Solmi, se Leopardi houvesse se destinado deliberadamente à Filosofia, "um espírito coerentemente sistemático como o seu teria provavelmente começado com uma gnosiologia, uma análise preventiva do pensamento como instrumento de conhecimento" [uno spirito coerentemente sistematico come il suo avrebbe probabilmente cominciato con uma gnoseologia, una preventiva analisi del pensiero come strumento di conoscenza]; (Cf. SOLMI, Sergio. Studi leopardiani: note su autori classici italiani e stranieri. Milano: Adelphi, 1987, pp. 43-44). Destacam-se aqui também as considerações de Porena em seu escrito II pessimismo di Giacomo Leopardi, acerca da importância da filosofia de Leopardi: “'Foi Leopardi um grande filósofo?' Se se é filósofo cada vez que por força de especulação se atinge uma verdade nova e profunda, Leopardi o [foi], e grandíssimo: pois, mesmo prescindindo da parte também verdadeira e eterna do seu sistema pessimístico (e qual sistema filosófico é todo verdadeiro e todo evidente?!), muitas verdades de toda espécie, [...] novas, [...] profundas, ele atingiu nas meditações que se acumulam no maravilhoso Zibaldone. [...] Sustento que o pensador foi nele [Leopardi] não menor do que o poeta, [...] um e outro [são] igualados pelo erudito. Pensar, sentir, saber, brilham nele com luz igualmente admirável, e fazem dele um dos espíritos mais extraordinários que honrem a humanidade" (Cf. PORENA, Manfredi. II pessimismo di Giacomo Leopardi [1923], in: Scritti leopardiani. Bologna: Zanichelli, 1959, p. 191).

${ }^{3}$ Ver aqui as observações sobre esse momento da vida de Leopardi: DAMIANI, Rolando. All'apparir del vero. Vita di Giacomo Leopardi. Milano: Mondadori, 2002. Em tal escrito Damiani narra as vicissitudes de Leopardi durante esse período e a influência delas na mudança de orientação da sua obra (ibidem, pp. 129-143). Pode-se indicar também o comentário de Natalino Sapegno acerca dessa conversão filosófica, em que ele se reporta ao Zibaldone, uma vez que tal obra pode "iluminar" uma compreensão da "total mutação" ocorrida no ânimo do escritor nesse ano. Sapegno cita ainda uma carta de Leopardi a Carlo Pepoli, de 1826, em que 
se destaca outro momento e uma nova crise no desenvolvimento do pensamento de Leopardi, isto é, aquela de $1824^{4}$. Certamente uma reflexão sobre esse novo período exige um conhecimento daquilo que foi pensado, anteriormente, acerca da viragem filosófica de $1819^{5}$, uma vez que as

se destaca a passagem das Letras à Filosofia. Ver, nesse sentido, SAPEGNO, Natalino. Leopardi: lezioni e saggi. Torino: Nino Aragno, 2006, pp. 95-96. Outro escrito que se reporta a esse período da "conversão filosófica" leopardiana é aquele de Spaggiari, em que ele comenta alguns pontos relevantes desse momento da experiência e compreensão de Leopardi de não corresponder ao ideal do perfeito escritor sonhado por Giordani, em 1817. Ver aqui SPAGGIARI, WILLIAM. L'eremita degli appennini: Leopardi e altri studi di primo Ottocento. Milano: Unicopli, 2000, pp. 15-28. Sobre esse argumento indica-se aqui também o seguinte escrito: CITATI, Pietro. Leopardi. Milano: Arnoldo Mondadori, 2010, pp. 76-79. Ainda sobre essa crise de 1819 e suas conseqüências imediatas ver TONELLI, Luigi. Leopardi. Milano: Cultura contemporânea, 1943, pp. 127-251. Também o escrito de: TELLINI, Gino. Leopardi. Roma: Salerno, 2001, pp. 93-108.

${ }^{4}$ Essa nova crise é aquela que interessa a pesquisa e será abordada ao longo da exposição, pois nela há uma mudança na concepção leopardiana da relação entre razão e natureza, pois a contradição vem identificada agora no interior da natureza, antes identificada na razão. Por conseguinte, ao se pensar as causas da infelicidade humana não deve ser mais identificada na razão, mas na própria natureza, responsável por todo o mal.

${ }^{5}$ Daí Leopardi escrever: "Quanto ao gênero de estudos que eu faço, como mudei em relação àquilo que fui, assim mudaram os estudos. Toda coisa que tenha de afetuoso e de eloquente me aborrece, parece-me brincadeira e ridícula criancice. Não busco nada mais exceto o verdadeiro que tanto já odiei e detestei. Contento-me de sempre descobrir mais e tocar com a mão a miséria dos homens e das coisas, e de horrorizar friamente, especulando esse arcano infeliz da vida do universo" [Quanto al genere degli studi che io fo, come io sono mutato da quel che io fui, cosi gli studi sono mutati. Ogni cosa che tenga di affettuoso e di eloqüente mi annoia, mi as di scherzo e di fanciullaggine ridicola. Non cerco altro più fuorché il vero, che ho già tanto odiato e detestato. Mi compiaccio di sempre meglio scoprire e toccar con mano la miséria degli uomini e delle cose, e d'inorridire freddamente, speculando questo arcano infelice e terribile della vita dell'universo];(Cf. LEOPARDI, Giacomo. Epistolario, in: Tutte le poesie e tutte le prose e lo Zibaldone. Roma: Newton\&Compton. 2010 (2 $2^{\mathrm{a}} \mathrm{ed}$.), p. 1276). Pertencem também a esse mesmo período, as primeiras alusões de Leopardi ao seu projeto de compor "diálogos satíricos à maneira de Luciano, mas extraídos os personagens e o ridículo dos costumes presentes, ou seja, modernos" [Dialoghi Satirici alla maniera di Luciano, ma tolti i personaggi e il ridicolo dai costumi presenti o moderni]; (Cf. LEOPARDI, Giacomo. Memorie e disegni letterari, in: Tutte le poesie e tutte le prose e lo Zibaldone. Roma: Newton\&Compton. 2010 (2 ${ }^{\mathrm{a}}$ ed.), p. 1109). Leopardi confessou também em outra carta de 4 de setembro, de 1820, a Giordani: "Nestes dias, quase para vingar-me do mundo, e quase também da virtude, imaginei e esbocei certas prosinhas satíricas". Ele pretende sacudir a Itália, conforme escreve em 27 de julho de 1821, e o seu século, por meio de diálogos e novelas lucianescas: levar para a comédia conteúdos até então pertencentes à tragédia. Ele acrescenta: "os vícios dos grandes, os princípios fundamentais das calamidades e da miséria humana, os absurdos da política, as inconveniências pertencentes à moral universal e à Filosofia, o andamento e o espírito geral do século, a essência das coisas, da sociedade, da civilização presente, as desgraças e as revoluções e as condições do mundo, os vícios e as infâmias não dos homens, mas do homem, o estado das nações, etc." (Cf. LEOPARDI, Giacomo. Zibaldone di pensieri, fragmentos 1393-1394, 27.07.1821, in: Tutte le poesie, tutte le prose e lo Zibaldone. Roma: Newton\&Compton. 2010 (2ªed.). p. 1774). 
indagações fundamentais se dirigiam, quer a um Leopardi filósofo quer a uma filosofia leopardiana ${ }^{6}$.

Nesse sentido indagou-se antes sobre o significado dessa filosofia, porém, nesta Tese não se busca mais investigar os seus fundamentos, mas, com base nela, e de forma mais específica, buscou-se expor o diagnóstico realizado por Leopardi em relação ao processo de modernização europeia e a situação particular da Itália. Por conseguinte, não se trata agora de uma reflexão sobre os fundamentos de certa filosofia, ou seja, a de Leopardi, mas de uma compreensão do que, tendo como base essa filosofia, Leopardi pôde interpretar, valendo-se de elementos históricos, econômicos, sociais, culturais, éticos e políticos, as degenerescências decorrentes das transformações realizadas pelo mundo moderno.

Já se conhece a crítica, apresentada por Leopardi, ao "amor" a sistemas no seu Zibaldone di pensieri ${ }^{7}$, uma vez que esse amor se revela como algo

\footnotetext{
${ }^{6}$ Sobre uma filosofia na obra leopardiana, ver: TILGHER, Adriano. La filosofia di Leopardi e studi leopardiani. Bologna: Massimiliano Boni, 1979. Para Boni, há um mérito nesse estudo sobre a obra de Leopardi, ou seja, a de haver dado crédito, embora de forma esagerada, ao Leopardi filósofo, ou na expressão de Tilgher, Leopardi "riflessivo", que, de acordo com Boni, trata-se de um termo que Leopardi usa de modo positivo, equiparando-o à especulativo. Daí indicar igualmente o seu uso em Zibaldone di pensieri (Ibidem, p. 5). Para Polizzi, o caminho leopardiano à Filosofia já se prepara após 1811, pois Leopardi, em 1812, com o Dialogo filosofico sopra un libro moderno intitolato "analise delle idee ad uso della gioventù" representa a primeira, não obstante imatura, prova de diálogo filosófico que tem como alvo os philosophes, mas que demonstra também um conhecimento, embora indireto, das teses do Dictionnaire philosophique [1764], de Voltaire, e o Émile ou de l'éducation [1762], de Rousseau (Cf. POLIZZI, Gaspare. Filosofia delle circostanze e immagini della scienza nello Zibaldone, in: POLIZZI, Gaspare (org.). Leopardi e la Filosofia. Firenze: Polistampa, 2001, p. 75). Ainda sobre a problemática da Filosofia e de uma originalidade no pensamento de Leopardi: Cf. SANSONE, Mario. Leopardi e la filosofia del Settecento, in: Storicità e letteratura da Machiavelli a Leopardi. Milano: Edizioni Scientifiche italiane, 1997, pp. 205-260. Já Sebastiano Timpanaro, no que concerne à problemática filosófica leopardiana, reporta-se à visão de Pietro Giordani, que não a compreendia "em sentido profissional, a qual [...] era estranho: compreendia uma visão do mundo coerente e livre de velhas e novas mitologias e, nesse sentido, o nome de filósofo cabe a Leopardi" [in senso professionale, alla quale [...] era straneo: intendeva una visione del mondo coerente e libera da vecchie e nuove mitologie, e in questo senso il nome di filosofo spetta al Leopardi]; (Cf. TIMPANARO, Sebastiano. Classicismo e illuminismo nell'ottocento italiano: testo critico con aggiunta di saggi e annotazioni autografe. Firenze: Le Lettere, 2011, p. 95). Sobre o problema de um Leopardi filósofo, destaca-se também: NADDEI CARBONARA, Mirella. L'eterno e il tempo in Giacomo Leopardi poeta filosofo. Napoli: Libreria Scientifica, 1973, pp. 11-60.

${ }^{7}$ Para Anna Dolfi, o Zibaldone, após nos ter ajudado a compreender, explicar, pôr-se ao lado da poesia de Leopardi ou da prosa, permanece ainda, como tema de estudo, totalmente desconhecido. Disto resulta, ao mesmo tempo, a nossa impotência de classificá-lo ou de atribuir-Ihe um gênero. Ademais, Dolfi identifica três disposições no interior desse texto, o filológico, o filosófico e o privado (Cf. DOLFI, Anna. Le verità necessarie. Leopardi e 10 "Zibaldone". Modena: Mucchi, 1995, pp. 9-10.). Ver ainda as considerações de Luigi Blasucci
} 
prejudicial ao verdadeiro. Sabe-se de ele reconhecer que, de certo sistema, nenhum verdadeiro pensador pode abster-se de constituir ${ }^{8}$, pois os grandes pensadores tiveram um sistema e foram formadores ou defensores de algum. Com excessão dos antigos filósofos, Leopardi considerou os maiores da modernidade: Descartes, Malebranche, Newton, Leibniz, Locke, Rousseau, Cabanis, Tracy, De Vico, Kant e outros ${ }^{9}$. Nesse sentido, Leopardi reuniu vários gêneros de pensadores, exercitados no domínio da moral, da política, da ciência do homem, em suas diversas partes e em vários saberes relativos à erudição, a fim de abordar a problemática concernente à construção de sistemas filosóficos.

É certo que a preocupação leopardiana considerava, quanto à problemática dos sistemas, ao sentido do método conduzido pelos filósofos, uma vez que se tratava da questão das razões da verdade. Daí identificar o equívoco em pensadores, que dos universais passavam ao particular, isto é, "do sistema a considerações das verdades que o devem formar" [dal sistema alla considerazione delle verità che lo debbono formare $]^{10}$. Leopardi justifica a

sobre uma nova edição do "Zibaldone", em que analiza as particularidades das edições de Flora, Le Monnier, Pacella, Binni e Ghidetti (Cf. BLASUCCI, Luigi. I tempi dei "Canti". Nuovi studi leopardiani. Torino: Giulio Einaudi, 1996, pp. 221-228). Tilgher diz poder se encontrar no Zibaldone materiais mais ou menos elaborados para, pelo menos, quatro livros, a saber "uma Teoria do Belo e da Arte, uma Teoria da Sociedade e da Civilização, uma Teoria do Prazer e uma Arte da Felicidade (títulos, estes dois últimos não meus, mas leopardianos), parte teórica a primeira e prática a segunda do Manual de filosofia prática, o qual Leopardi sonhava de transmitir o seu nome" [una Teoria del Bello e dell'Arte, una Teoria della Società e della Civiltà, una Teoria del Piacere e della Felicità (titoli, questi ultimi due, non miei, ma leopardiani), parte teorica la prima e pratica la seconda del Manuale di filosofia pratica, cui Leopardi vagheggiava di legare il suo nome]; (Cf. TILGHER, Adriano. La Filosofia di Leopardi e studi leopardiani, p. 17).

${ }^{8}$ Não se pode deixar aqui de indicar alguns estudos clássicos no domínio dos estudos sobre um sistema leopardiano. Nesse sentido, ver: ZUMBINI, Bonaventura. Studi sul Leopardi, vol. I, Firenze: G. Barbèra, 1902; vol. II, Firenze: G. Barbèra, 1904; Para Zumbini, o acordo do sistema leopardiano com os dogmas cristãos diminui à medida que predominam as suas ideias contrárias a toda concepção teológica do mundo (Cf. ZUMBINI, Bonaventura. Studi sul Leopardi, Vol. I, p. 149. Ver também GATTI, Pasquale. Esposizione del sistema filosofico di Giacomo Leopardi: Saggio sullo Zibaldone. Vols. I-II, Firenze: Le Monnier, 1906. Destaca-se aqui também GATTI, Pasquale. L'unità del pensiero leopardiano: saggio critico-polemico. Napoli: Editore: Dott. Gennaro Giannini, 1921.

${ }^{9}$ Cf. LEOPARDI, Giacomo. Zibaldone di pensieri, fragmento 946, 16.04.1821, in: Tutte le poesie, tutte le prose e lo Zibaldone, p. 1674.

${ }^{10}$ LEOPARDI, Giacomo. Zibaldone di pensieri, fragmento 947, 16.04.1821, in: Tutte le poesie, tutte le prose e lo Zibaldone, p. 1675. 
sua crítica por reconhecer que, nesse procedimento, os particulares são extraídos à força a fim de adequá-los ao sistema já formado.

Parece contraditório que após as suas considerações sobre "a pestífera mania de formar sistemas" [la pestifera smania di formare sistemi], herança tão odiada da Escolástica, Leopardi houvesse também proposto um "sistema"11. Em seu Zibaldone di pensieri pode-se encontrar algumas considerações que refletem a natureza desse sistema, uma vez que ele busca refutar toda forma de dogmatismo, introduzindo no seu interior aquilo que ele designou como um "ceticismo raciocinado e demonstrado" [Scetticismo ragionato e dimostrato] ${ }^{12}$. Por conseguinte, a razão não pode, em absoluto, encontrar o verdadeiro sem a mediação da dúvida, pois o verdadeiro consiste essencialmente nessa dúvida $^{13}$. Falar, porém, de sistema leopardiano, significa considerá-lo como "sistema das coisas humanas" [sistema delle cose umane] ou ainda "teoria do homem" [teoria dell'uomo], pois assim se evita generalizações e simplificações ${ }^{14}$.

${ }^{11}$ Para Leopardi, o sistema é "a conexão e dependência das ideias, dos pensamentos, das reflexões, das opiniões, é, porém, o distintivo certo e, ao mesmo tempo, indispensável ao filósofo" [la connessione e dipendenza delle idee, de' pensieri, delle riflessioni, delle opinioni, è il distintivo certo, e nel tempo stesso indispensabile del filosofo]; Cf. LEOPARDI, Giacomo. Zibaldone di pensieri, fragmento 950, 17.04.1821, in: Tutte le poesie, tutte le prose e lo Zibaldone, p. 1675.

${ }^{12}$ Conforme Leopardi comenta em seu Zibaldone, o seu sistema introduz "não só um Ceticismo refletido e demonstrado, mas tal que, segundo o meu sistema, a razão humana, seja qual for 0 progresso possível, não poderá jamais se despir desse ceticismo; aliás, ele contém 0 verdadeiro, e se demonstra que a nossa razão, não pode, em absoluto, encontrar o verdadeiro senão duvidando; que ela se distancia do verdadeiro toda vez que julga com certeza; e que não só a dúvida favorece descobrir o verdadeiro [...], o verdadeiro consiste essencialmente na dúvida, e quem duvida, sabe, e sabe o mais que se possa saber" [non solo uno Scetticismo ragionato e dimostrato, ma tale che, secondo il mio sistema, la ragione umana per qualsivoglia progresso possibile, non potrà mai spogliarsi di questo scetticismo; anzi esso contiene il vero, e si dimostra che la nostra ragione, non può assolutamente trovare il vero se non dubitando; ch'ella si allontana dal vero ogni volta che giudica con certeza; e che non solo il dubbio giova a scoprire il vero [...] ma il vero consiste essenzialmente nel dubbio, e chi dubita, sa, e sa il più che si possa sapere]; (Cf. LEOPARDI, Giacomo. Zibaldone di pensieri, fragmento 1655, 08.09.1821, in: Tutte le poesie, tutte le prose e lo Zibaldone, p. 1821). Sobre o ceticismo leopardiano, ver aqui: RENZI, Giuseppe. Lo scetticismo estetico di Leopardi. Ferrara: Gallio, 1990.

${ }^{13}$ Cf. LEOPARDI, Giacomo. Zibaldone di pensieri, fragmento 1655, 08.09.1821, in: Tutte le poesie, tutte le prose e lo Zibaldone, p. 1821.

${ }^{14}$ Cf. LEOPARDI, Giacomo. Zibaldone di pensieri, fragmentos 181, 12-23.07.1820, frag. 270, 11.10.1820, frag. $960,19.04 .1821$, frag. $2616,28.08 .1822$ e frag. 3659, 11.10.1823), in: Tutte le poesie, tutte le prose e lo Zibaldone, pp. 1528, 1549, 1678, 1979 e 2170. Leopardi pretende demonstrar, adotando "provas gerais e particulares" [prove generali e particolari] como "o homem fosse feito primitivamente para a felicidade, como o seu estado perfeitamente natural 
O principal ensinamento do seu "sistema"15 era, portanto, o de explicar as razões da "degeneração do homem de um estado primitivo mais perfeito e feliz" [degenerazione dell'uomo da uno stato primitivo più perfetto e felice] ${ }^{16}$, constituindo também um dos "principais dogmas" do Cristianismo. Foi, portanto, a preocupação com essa degeneração que motivou Leopardi à sua insistente reflexão sobre a felicidade: como o homem fosse feito primitivamente para a felicidade, isto é, como o seu estado perfeitamente natural, pois o único perfeito, e quanto mais se distanciasse da natureza tanto mais se tornava infeliz ${ }^{17}$. Tratava-se, nesse momento, de encontrar os fundamentos da contradição em relação à questão da felicidade. Por isso, ao considerar a relação natureza-razão, Leopardi identificou na razão, e não no "sistema da natureza" [sistema della natura ${ }^{18}$, a contradição ${ }^{19}$.

(que não se encontra nunca no fato) fosse para ele o único perfeito, como quanto mais nos distanciamos da natureza, tanto mais nos tornamos infelizes" [l'uomo fosse fatto primitivamente alla felicita, come il suo stato perfettamente naturale (che non si trova mai nel fatto) fosse per lui il solo perfetto, come quanto più ci allontaniamo dalla natura, tanto più diveniamo infelici]; (Cf. LEOPARDI, Giacomo. Zibaldone di pensieri, fragmento 1004, 01.05.1821, in: Tutte le poesie, tutte le prose e lo Zibaldone, p. 1688).

${ }^{15}$ Em sua concepção de sistema, Leopardi propõe a defesa da "atividade" [ativita], o "espírito de energia" [spirito di energia] predominante em grande parte da Europa, tornando assim os homens cada vez mais "ativos" [ativl] e "ocupados" [occupati]. Segundo o seu sistema, o "estado selvagem" [stato selvaggio], ou seja, "o ânimo o menos desenvolvido, o menos sensível, o menos ativo, como a melhor condição possível da felicidade humana" [l'animo il meno sviluppato, il meno sensibile, il meno attivo, come la miglior condizione possibile per la felicita umana]; (Cf. LEOPARDI, Giacomo. Zibaldone di pensieri, fragmentos 4187-4188, 13.07.1826, in: Tutte le poesie, tutte le prose e lo Zibaldone, p. 2312).

${ }^{16}$ LEOPARDI, Giacomo. Zibaldone di pensieri, fragmento 1004, 01.05.1821, in: Tutte le poesie, tutte le prose e lo Zibaldone, p. 1688.

17 Cf. LEOPARDI, Giacomo. Zibaldone di pensieri, fragmento 1004, 01.05.1821, in: Tutte le poesie, tutte le prose e lo Zibaldone, p. 1688.

${ }^{18}$ Conforme Leopardi escreve no Zibaldone, "o plano, o sistema, a máquina da natureza, está composta e organizada de outra maneira daquela da razão, e não responde à exatidão matemática" [il piano, il sistema, la macchina della natura, è composta e organizzata in altra maniera da quella della ragione, e non risponde all'esattezza matemática]; LEOPARDI, Giacomo. Zibaldone di pensieri, fragmento 586, 29-31.01.1821, in: Tutte le poesie, tutte le prose e lo Zibaldone, p. 1610. Em oposição ao procedimento dos filósofos modernos em relação ao sistema da natureza, Leopardi argumenta: "Esta é também uma grande fonte de erros nos filósofos, sobretudo modernos, os quais habituados à exatidão e precisão matemática, tão usual e na moda hoje em dia, consideram e medem a natureza com essas normas, pensam que o sistema da natureza deva corresponder a esses princípios; e não pensam como natural aquilo que não é preciso e matematicamente exato" [Questa pure è una gran fonte di errori ne' filosofi, massime moderni, i quali assuefatti all'esattezza e precizione matemática, tanto usuale e di moda oggidí, considerano e misurano la natura com queste norme, credono che il sistema della natura debba corrispondere a questi principii; e non credono naturale quello che non è preciso e matematicamente esatto]; LEOPARDI, Giacomo. 
Em tal momento dessa obra, Leopardi seguia ainda os paralogismos de Jean-Jacques Rousseau (1712-1778) ${ }^{20}$ para justificar o fato da infelicidade humana no domínio da razão e não do estado de perfeição natural. Ao deixar de obedecer às "inclinações primitivas" [primitive inclinazioni], o homem se

Zibaldone di pensieri, fragmento $584,23-31.01 .1821$, in: Tutte le poesie, tutte le prose e lo Zibaldone, p. 1610.

${ }^{19}$ Domenico Consoli, em seu Leopardi: natura e società, afirma que a polêmica de Leopardi contra a razão e contra aspectos a ela subordinados, como por exemplo, a sociedade, o progresso e a perfectibilidade, tem como fundamento o axioma de que o "viver civil" [vivere civile] tenha se distanciado da natureza, por ser ela "única forma e razão do ser, a norma e o modelo das coisas, o valor exemplar ao qual continuamente referir-se para dar sentido ao juízo" [l'unica forma e ragione dell'essere, la norma e il modello delle cose, il valore esemplare vui continuamentamente riferirsi per dar senso al giudizio]; (Cf. CONSOLI, Domenico. Leopardi: natura e società, Roma: Studium, 1977, p. 57.

${ }^{20}$ A influência de Rousseau no pensamento leopardiano é destacada por Vanna Gazzola Stachini, em seu Leopardi politico, pois afirma de modo geral que uma aproximação entre esses pensadores se deve, sobretudo, ao modo de eles buscarem a felicidade, uma vez que é pública, mas também privada, "um estatuto do coração e não apenas um estatuto jurídico" [un statuto del cuore e non solo uno statuto giuridico]; (Cf. STACHINI GAZZOLA, Vanna. Leopardi politico. Bari: De Donato, 1974, p. 27. Domenico Consoli também compartilha a ideia de aproximação e influência do primeiro Rousseau sobre Leopardi. Este último, ao identificar a perfeição do homem nos inícios da história, torna inevitável a negação da ideia de progresso, pois essa ideia corresponde à de corrupção, por conseguinte, distanciamento da perfeição da natureza: "efeito de uma obstinação culpada do homem" [effetto d'un'ostinazione colpevole dell'uomo]; (Cf. CONSOLI, Domenico. Leopardi: natura e società, pp. 43-47. Sobre a afirmação de uma divergência substancial entre as posições de Rousseau e Leopardi escreve Luporini: "Rousseau vive ante rem e Leopardi vive post rem, e essa coisa, decisiva para a posição histórica de ambos, é a grande revolução. Rousseau havia aberto a estrada à revolução e [...] também ao romantismo. Ora, Leopardi que vive no [tempo do] romantismo, o refuta e não se abandona às solicitações éticas e políticas que provinham dele. $\mathrm{E}$ aqui está o ponto mais delicado para entender toda a posição de Leopardi, o seu drama, o seu íntimo dissídio, porque não é tanto e apenas um dissídio pessoal e subjetivo, mas um dissídio histórico. [...] a razão do século XVIII, que ele condena é também a razão que ele ama, a única que ele reconhece e sempre reconhecerá como tal, aquela precisamente que tinha produzido a filosofia racionalista e materialista do '700, [...] que tinha acendido tantas esperanças em todo o campo da civilização humana, e, sobretudo, da vida social e politica, esperanças as quais Leopardi ainda participa e que, todavia, as encontra desiludidas nos próprios tempos. Na raiz de todo 0 posicionamento de Leopardi ante a 'razão' e ante a 'filosofia' está essa desilusão histórica, cujo momento político é, naturalmente, decisivo. A razão que devia destruir para sempre a barbárie, as superstições, instaurar a igualdade e a democracia, reconduzir o homem civil ao justo e são equilíbrio com a natureza, destruído nos 'baixos tempos', destruído pelo Cristianismo, e depois por aquele acmè de despotismo que foi, segundo Leopardi, o '600, [...] essa razão faliu, a revolução por essa produzida regrediu, e disso nasceu o despotismo napoleônico e depois, sobretudo, a época presente, a [R]estauração, cuja melhor coisa, mais progressiva, [foi] o compromisso liberal e monárquico-constitucionalistico, ao qual Leopardi, mesmo reconhecendo o relativo valor, repugna como diante de todos os compromissos" (Cf. LUPORINI, Cesare. Leopardi progressivo [1947]. Roma: Riuniti, 2006, pp. 49-50); Segundo Rigoni, Luporini teria abandonado, posteriormente, a tese que defendia a associação do pensamento leopardiano à causa de um suposto progresso político ou científico em uma entrevista ao jornal Espresso (Leopardi moderno, de F. Adornato, $1^{\circ}$ marzo, 1987, pp. 108-16), ver RIGONI, Mario Andrea. Introduzione, in: Giacomo Leopardi. Strage delle illusioni, pensieri sulla politica e sulla civiltà, Milano: Adelphi, 1993 ( $2^{\mathrm{a}}$ ed.), nota 1, p. 29; Ainda sobre a relação entre Rousseau e Leopardi ver o seguinte estudo: KOOPMANN, Susanne. Studi sulla recondita presenza di Rousseau nell'opera di Giacomo Leopardi. Trad. it. Valentina Di Rosa, Cosenza: Memoria, 2003. 
alterou, no entender de Leopardi, e assim se tornou imperfeito em relação à sua própria natureza, ou seja, tornou-se infeliz. Nesses argumentos, Leopardi insistia ainda na superioridade da natureza sobre a razão, por causa da incapacidade dela em substituir a natureza: "o homem é livre por natureza e igual a qualquer outro da sua espécie" [l'uomo per natura è libero e uguale a qualunque altro della sua specie] ${ }^{21}$.

Contudo, no "estado social" [stato sociale], as coisas ocorrem de maneira diversa, uma vez que a razão, o princípio, a finalidade da sociedade é o bem comum daqueles que a compõem e se unem em um corpo mais ou menos amplo ${ }^{22}$. Se a sociedade não realiza esse fim, ela não é apenas irracional, mas "inútil" [inutile] e "prejudicial" [dannosa] ao homem. Por conseguinte, se esse fim, por ventura, não se realiza, convém, conforme Leopardi, dissolver a sociedade, uma vez que esta em si mesma, independente desse fim, conduz o homem mais a prejuízos que vantagens ${ }^{23}$. Nesse sentido, o "bem comum" [ben commune] só se realiza em uma sociedade com a cooperação de todos os seus membros e visando tal objetivo.

Esta Tese não descura as formulações, apresentadas por Leopardi, acerca de uma "filosofia dolorosa" [filosofia dolorosa $]^{24}$, conforme as suas reflexões explicitadas nas Operette morali, pois no domínio de uma abordagem sobre essa filosofia, pode-se encontrar alguns pontos decisivos de crítica aos costumes, por revelar intolerância contra toda "simulação" [simulazione] e "dissimulação" [dissimulazione]. Conforme proclama Eleandro-Leopardi nas Operette: "arranquem as máscaras, permaneçam com suas roupas, não farão

${ }^{21}$ LEOPARDI, Giacomo. Zibaldone di pensieri, fragmento 545, 22-29.01.1821, in: Tutte le poesie, tutte le prose e lo Zibaldone, p. 1603.

${ }^{22}$ Cf. LEOPARDI, Giacomo. Zibaldone di pensieri, fragmento 545, 22-29.01.1821, in: Tutte le poesie, tutte le prose e lo Zibaldone, p. 1603.

${ }^{23}$ Cf. LEOPARDI, Giacomo. Zibaldone di pensieri, fragmento 545, 22-29.01.1821, in: Tutte le poesie, tutte le prose e lo Zibaldone, p. 1603.

${ }^{24}$ Cf. LEOPARDI, Giacomo. Operette morali, a cura di Cesare Galimberti, Napoli: Guida, 1998, p. 497. Tal filosofia refuta "toda consolação e todo engano pueril" [rifiuto ogni consolazione e ogn'inganno puerile] e sustenta, com coragem, "a privação de toda esperança" [la privazione di ogni speranza], olhando de forma intrépida, "o deserto da vida" [il deserto della vita], enfim, não dissimula nenhuma parte da infelicidade humana, aceitando todas as consequências de semelhante concepção filosófica. Privilegia-se aqui, na pesquisa sobre as Operette morali, a edição de Cesare Galimberti, pois oferece um importante ensaio introdutório e notas filológicas elaboradas para uma melhor compreensão dessa obra leopardiana. 
menor efeito que antes e estarão mais à vontade"25. Ademais, Leopardi também expressa uma crítica à orientação filosófica do pensamento moderno. Ele rechaça todo engano produzido pelo intelecto na sua busca da verdade, pois sabe que o gênero humano acredita sempre em tantas tolices, mas jamais aceitará que "nada sabe, que não é nada e que nada tem a esperar" [di non saper nulla, né di non essere nulla, né di non aver nulla a sperare] ${ }^{26}$ : indagações tão relevantes para todo filósofo moderno por se reportarem ao homem.

O teor dessa "filosofia dolorosa" é estranha, como Leopardi mesmo busca expressar por meio dos personagens de dois diálogos das Operette morali, a saber, Diálogo de Timandro e Eleandro [Dialogo di Timandro e Eleandro], de 1824, e Diálogo de Tristão e um amigo [Dialogo di Tristano e di un amico] ${ }^{27}$, de 1832: uma filosofia para um século "dedicado sobretudo à filantropia" [dedito sopra tutto alla filantropia] ${ }^{28}$. Essa filosofia revela a sua verdade fundamental, ou seja, a de que somos e fomos sempre infelizes. Daí não existir, para a condição humana, qualquer possibilidade de "melhoria", "aperfeiçoamento" e "perfectibilidade". Aqui se apresenta a crítica leopardiana aos ideais iluministas e, sobretudo, ao ideal de progresso: tão caro à orientação filosófica moderna. Para Leopardi, as "ilusões naturais do espírito" [illusioni naturali dell'animo] e as "divagações" não deveriam ter sido eliminadas pela "civilização moderna" [civiltà moderna] ${ }^{29}$. Em oposição à unilateralidade da racionalidade moderna, e na busca de recuperar disposições poéticas

${ }^{25}$ LEOPARDI, Giacomo. Operette morali, a cura di Cesare Galimberti, Napoli: Guida, 1998, p. 423: "Cavinsi le maschere, si rimangano coi loro vestiti; non faranno minori effetti di prima, e staranno più a loro agio".

${ }^{26}$ Cf. LEOPARDI, Giacomo. Operette morali, a cura di Cesare Galimberti, Napoli: Guida, 1998, p. 496.

${ }^{27}$ Cf. LEOPARDI, Giacomo. Operette morali, a cura di Cesare Galimberti, Napoli: Guida, 1998, pp. 415-431, 493-515. Para um estudo mais acurado das Operette morali ver os seguintes estudos, BINNI, Walter. Lettura delle Operette morali. Genova: Marietti 1820, 1987; FIGURELLI, Fernando. Lettura delle "Operette morali" del 1824. Lezioni dell'anno accademico 1975-76. Napoli: De Simone, 1976; Ver também, CAMPAILLA, Sergio. La vocazione di Tristano. Storia interiore delle "Operette morali". Bologna: Pàtron, 1977.

${ }^{28}$ Ver ainda: LEOPARDI, Giacomo. Operette morali, a cura di Cesare Galimberti, Napoli: Guida, 1998, p. 419.

${ }^{29}$ Cf. LEOPARDI, Giacomo. Operette morali, a cura di Cesare Galimberti, Napoli: Guida, 1998, p. 430. 
humanas $^{30}$, Leopardi propõe a sua "ultrafilosofia" [ultrafilosofia] ${ }^{31}$ como via de recuperar a integralidade antropológica humana, e de pensar igualmente outra concepção de filósofo, na medida em que se articulam filosofia e poesia e se afirma a importância da imaginação e da conservação das ilusões ${ }^{32}$.

Após tal excurso nesses pressupostos - investigados e abordados como tema da pesquisa anteriormente indicada - torna-se possível justificar este momento da investigação e do tema desta Tese. Trata-se agora de enfrentar a crítica de Leopardi à Modernidade e o seu diagnóstico realizado com base nas

${ }^{30}$ Compreendem-se aqui, por essas disposições, faculdades como os sentidos, a imaginação, a fantasia, o engenho e a faculdade poética, pois integram o universo da vitalidade e criação humanas.

${ }^{31}$ Ante as contradições do mundo moderno e os rumos de certa racionalidade, Leopardi sustenta: "um povo de filósofos seria o menor e mais covarde do mundo. Por isso a nossa regeneração depende de uma (...) ultrafilosofia, que conhecendo o todo e o íntimo das coisas, nos aproxime da natureza. E esse deveria ser o fruto das luzes extraordinárias deste século" [un popolo di filosofi sarebbe il più Piccolo e codardo del mondo. Perciò la nostra rigenerazione dipende da una (...) ultrafilosofia, che conoscendo l'intiero e l'intimo delle cose, ci ravvicini alla natura. E questo dovrebb'essere il frutto dei lumi straordinari di questo secolo]. Cf. LEOPARDI, Giacomo. Zibaldone di pensieri (fragmento 115, 07.06.1820), p. 1510. O argumento sobre a filosofia leopardiana e, em particular, a questão da ultrafilosofia pode ser encontrado em POLIZZI, Gaspare. Leopardi e "le ragioni della verità". Scienze e filosofia della natura negli scritti leopardiani. Roma: Carocci, 2003, pp. 63-64. Sobre o conceito de ultrafilosofia e mezza filosofia no interior do pensamento leopardiano ver, LUPORINI, Cesare. Leopardi progressivo [1947]. Roma: Riuniti, 2006, pp. 55-62; Ver também FERRUCCI, Carlo. Leopardi filosofo e le ragioni della poesia. Venezia: Marsilio, 1987, pp. 11- 84. Em tal obra Ferrucci comenta igualmente a problemática da ultrafilosofia leopardiana e ainda de uma filosofia social (ibidem, p. 85). Ver também: CONSOLI, Domenico. Leopardi: natura e società, p. 38.

${ }^{32}$ Cf. LEOPARDI, Giacomo. Zibaldone di pensieri, fragmento 115, 07.06.1820, in: Tutte le poesie, tutte le prose e lo Zibaldone, p. 1510 . Na mesma obra, Leopardi se serve também do termo mezza filosofia, a fim de problematizar a forma da racionalidade moderna, ou seja, os inconvenientes decorrentes desse modelo: ver aqui, LEOPARDI, Giacomo. Zibaldone di pensieri, fragmentos 520, 521 e 522, 17.01.1821; fragmento 1078, 23.05 .1821 e fragmento 1793, 26.09.1821, in: Tutte le poesie, tutte le prose e lo Zibaldone, pp. 1599, 1704-1705 e 1845. Sobre a relação entre poesia e filosofia como crítica da razão moderna em Leopardi, escreve Prette: "A crítica da ratio não é conduzida a partir de um fechar-se pascaliano nas 'razões do coração', nem pela evocação de um 'retorno ao antigo', [...] nem também pelo interior da oposição bárbaro-civil. É a crítica de um modo de conhecimento que vai desenhando-se como forma de poder, portanto exclusivo, desestruturante, opressivo: a ratio iluminista que atribui legitamação ao poder da Restauração, e por isso poderá delegar à cultura romântica o domínio do 'sentimento', da imaginação, das paixões, e permitir que a poesia volte a ser poesia, contemplação precisamente romântica, voz de um povo perdido que fala no novo poeta, e a Filosofia volte a ser Filosofia, ou seja, representação organizada da natureza. A crítica da razão, em nome do pensar poetante e da poesia pensante, é conduzida por Leopardi não sob o princípio do sacro e do dionisíaco, [...] nem também no sonho schelegeliano de uma 'profética' armonia entre poesia e filosofia, mas no horizonte da interpretação da natureza: caso contrário, no cenário dessa crítica comparecem as figuras do 'antigo', o saber da morte, a crítica da desapropriação da língua do corpo. Figuras de um discurso que vai além da linha 'sensística' do século XVIII iluminista, e fazem da escritura leopardiana uma crítica permanente das formas de poder" (Cf. PRETTE, Antonio. Pensiero poetante e poesia pensante, in: II pensiero poetante. Saggio su Leopardi [1980]. Milano: Feltrinelli, 2006, pp.88-89). 
mudanças ocorridas no desenvolvimento de seu pensamento, ou seja, pressupor a crise de 1819 e aquela que se anuncia em 1824. Daí se destacar outro período de sua obra, ou seja, o de $1824^{33}$, e aprofundar a sua reflexão sobre a Modernidade valendo-se de uma filosofia social e política. Nesse sentido se destaca como obra relevante desta pesquisa o Discorso sopra lo stato presente dei costumi degl'italiani, escrito em 1824, pois se apresenta nesta pesquisa como orientação da compreensão leopardiana concernentes à problemática moderna e às suas especificidades na Europa.

A escolha desse Discorso, como ponto de partida deste estudo, se justifica em virtude da complexidade apresentada por Leopardi em suas análises. Tal complexidade se revela na riqueza da sua orientação de pensamento que abrange elementos do desenvolvimento das sociedades modernas europeias, considerando as conquistas econômicas, sociais, culturais, antropológicas, morais, éticas, estéticas e políticas. Nesse escrito Leopardi revela, seja a especificidade do atraso italiano sejam as linhas gerais da modernização em nações como França, Alemanha e Inglaterra ${ }^{34}$.

Não obstante essa crise, algumas categorias retornam nesse Discorso assumindo não mais uma preocupação com a problemática do seu "sistema" filosófico ou de questões internas à Filosofia, ou seja, de natureza gnosiológica, epistemológica ou metafísica. Por conseguinte, categorias como natureza, ilusão, imaginação, poesia, civilização clássica, razão, civilização moderna, sociedade, religião, filosofia, moral, vacuidade, barbárie, egoísmo, vitalidade, são agora abordadas muito mais no domínio de uma filosofia prática, ou seja, consideradas em um universo ético e político. É certo que Leopardi não abandona o parâmetro da civilização antiga, contudo reconhece a impossibilidade de se recuperar de fato o mundo já perdido, após o ocaso das

\footnotetext{
${ }^{33}$ Trata-se aqui da terrível descoberta de Leopardi, ocorrida em 11 de maio de 1824, destinada a devastar a sua fé na bondade da natureza, pois descobre a contradição inerente à natureza e não mais na razão. Daí a sua indagação: "Quem sabe me explicar esta contradição na natureza?" [Qui mi sa spiegare questa contraddizione in natura?]; (Cf. LEOPARDI, Giacomo. Zibaldone di pensieri, fragmento 4087, 11.05. 1824 in: Tutte le poesie, tutte le prose e lo Zibaldone, p. 2280. Sobre as diversas acepções do termo natureza em Leopardi e a possibilidade de problemas no desenvolvimento de seu pensamento e de seu "sistema", ver CONSOLI, Domenico. Leopardi: natura e società, pp. 57-121.

${ }^{34}$ Cf. LEOPARDI, Giacomo. Discorso sopra lo stato presente dei costumi deglitaliani [1824]. Milano: BUR, 1998.
} 
ilusões. Por isso, mesmo mantendo ainda a sua crítica ao ideal de progresso, constituído de forma ideológica pelas filosofias da história, ele enfrenta a problemática da modernização, interpretando-a como algo de fato ocorrido na história.

O primado desse Discorso, na presente investigação, não exclui certamente outras obras que permitem esclarecer e aprofundar uma exposição, mesmo modificando a sua orientação e o seu procedimento. Nesse sentido, retoma-se aqui aquele pensamento leopardiano correspondente a esse período, daí se considerar, de forma mais precisa, certo sentido cronológico das obras, a fim de uma coerência com a orientação do tema e sua especificidade. Entre as obras leopardianas destacam-se ainda nesta investigação: o Epistolario [1810-1835], Canti [1816-1836], Zibaldone di pensieri [1817-1832], Discorso di um italiano intorno alla poesia romantica [1818], Disegni letterari [1819-1821], Operette morali [1824-1835], Pensieri [1830-1835], mas também outros textos ainda não investigados e apresentados na pesquisa anterior, a saber, Dissertazioni filosofiche [1811-1812], Saggio sopra gli errori popolari degli antichi [1815], Lettera ai compilatori della Biblioteca Italiana [1816], Lettera ai Sigg. Compilatori della Biblioteca Italiana in risposta a quella di Mad. la baronessa di Staël Holstein ai medesimi [1816], Paralipomeni della Batracomiomachia [1831] $]^{35}$.

$\mathrm{Na}$ abordagem do presente tema propuseram-se as seguintes hipóteses interpretativas a fim de constituir certa leitura e ordem de argumentos, possibilitando ao mesmo tempo uma articulação entre as partes e os capítulos desta Tese. Tais hipóteses, já apresentadas no resumo deste trabalho, são as seguintes: i) o Discorso sopra lo stato presente dei costumi degl'italiani ${ }^{36}$,

35 As datas acima dispostas, em relação às obras, priorizam a ordem cronológica de elaboração do pensamento leopardiano, em virtude da necessidade desta pesquisa em considerar, de forma rigorosa, uma cronologia em relação à dimensão biográfica e de elaboração da obra leopardiana. Não se trata das datas de publicação e de edições.

${ }^{36}$ No estudo realizado sobre esse Discorso adotaram-se várias edições em virtude da necessidade de uma leitura das notas apresentadas nos estudos e aquelas notas filológicas, apresentadas pelos organizadores. Ver, nesse sentido, LEOPARDI, Giacomo, Dei costumi degl'italiani (org.) Augusto Placanica. Venezia: Marsilio, 1992 (2 $2^{\mathrm{a}}$ Ed.); (orgs.) Salvatore Veca e Maurizio Moncagatta. Milano: Feltrinelli, 1991; (orgs.) Lucio Felici e Emanuele Trevi. Roma: Newton\&Compton, 1997; (orgs.) Mario Andrea Rigoni, Marco Dondero e Roberto Melchiori. Milano: BUR, 2006. 
escrito em 1824, contribui para uma compreensão da análise leopardiana acerca do processo de modernização européia; ii) o Discorso pressupõe uma nova mudança no desenvolvimento da obra leopardiana, a da crise de 1824 na qual se modifica a concepção de natureza, não mais aquela amorosa, mas uma natura matrigna [natureza madrasta] ${ }^{37}$ responsável por todos os males e infelicidade humana; iii) Leopardi com base em um diagnóstico da situação econômica, social, cultural e política italiana expõe pontos fundamentais das mudanças ocorridas após o processo de modernização europeu; iv) no seu diagnóstico sobre a modernização ele indica um novo princípio de conservação da vida civil; v) a experiência da modernização, em virtude da nova forma de racionalidade e de espiritualização das forças, põe em risco toda vitalidade humana e conduz a uma nova barbárie: "barbárie da sociedade" [barbarie della società].

Para uma disposição dos argumentos, em consonância com o tema deste estudo, optou-se, de início, por uma divisão em duas partes: a primeira visando explicitar, com base no Discorso, de 1824, a reflexão leopardiana sobre a situação da Itália ante o processo de modernização das nações europeias. Trata-se de expor, valendo-se das análises leopardianas, as características gerais dessa modernização na Europa e os inconvenientes humanos e sociais decorrentes dela. A primeira parte se apresenta como um pressuposto antropológico e cultural, ou seja, como um solo concreto para se assegurar o andamento posterior da exposição; a segunda aprofunda, sobretudo, alguns argumentos que reforçam a compreensão das degenerescências inerentes ao mundo moderno. Daí se explicitar as consequências decorrentes do desaparecimento do antigo ethos e os inconvenientes oriundos do desaparecimento das antigas ilusões. Destaca-se,

\footnotetext{
${ }^{37}$ Para identificar a mudança leopardiana, ocorrida em 1824, em relação à concepção de natureza, considera-se aqui a ideia de uma natureza "madrasta", como indicam os Canti [18181835], natureza outrora bondosa em seu pensamento. Leopardi escreve em um dos versos de La Ginestra [1836]; v. 125: "mãe é no parto e no querer madrasta" [madre è di parto e di voler matrigna]; (Cf. LEOPARDI, Giacomo, Canti [1818-1835], a cura di Ugo Dotti, Milano: Feltrinelli, 2006 (5 ed.), p. 453). Ver ainda nas Operette morali, a saber, o Diálogo da natureza e de um islandês [Dialogo della natura e di un islandese], escrito em 1824. (Cf. LEOPARDI, Giacomo, Operette morali [1824-1832], a cura di Cesare Galimberti, Napoli: Guida, 1998 (5aㅡ ed.), pp. 233247).
} 
em especial, a análise de Leopardi sobre os riscos da nova barbárie. Essas duas partes buscam uma articulação com o conteúdo específico dos capítulos.

O primeiro capítulo [Leopardi e os costumes dos italianos: abordagem sobre a modernização no Discorso de 1824] explicita o tratamento leopardiano da modernização, pois apresenta, ao mesmo tempo, uma análise comparativa entre situação italiana e aquela europeia. Destaca-se, em particular, a via adotada por nações como a França, a Alemanha e a Inglaterra para compensar o desaparecimento de elementos que possibilitavam aos liames civis pertencentes à civilização clássica, com outras formas adequadas às características do mundo moderno. Nesse sentido, sobressaem o advento das "sociedades estritas" [società strette], da opinião pública, do bom tom, da honra, da conversação, ou seja, a constituição de certos costumes necessários à conservação da vida civil. Ademais, o Discorso também revela o diagnóstico de Leopardi em relação à Itália contemporânea, ou seja, de ser incapaz de constituir costumes e de criar novos vínculos sociais.

Já o segundo [Civilização meridional e meridionalidade: a problemática leopardiana entre antigos e modernos] estabelece um paralelo entre civilização meridional e civilização setentrional. Com base ainda no Discorso, e em algumas formulações do Zibaldone di pensieri, este capítulo expõe o paralelo realizado por Leopardi do deslocamento de certas características, pertencentes anteriormente à civilização clássica, como civilização meridional, para o setentrião. Neste capítulo enfrentam-se as características identificadas por Leopardi, outrora pertencentes aos países do meridião e apresentadas agora no setentrião. Se a imaginação foi tão rica nas nações do meridião, agora pertence ao setentrião. Nesses argumentos Leopardi enfrenta questões como o clima, temperamentos, gêneros de vida, não esquecendo a relação estabelecida entre antigos e modernos e as novas características da civilização moderna.

O terceiro capítulo [Modernidade e fim do antigo ethos: a reflexão leopardiana] dá prosseguimento à abordagem de argumentos que já preparam uma reflexão sobre a barbárie, valendo-se igualmente da relação entre o fim do antigo ethos e a strage delle illusioni. Neste capítulo consideram-se as 
reflexões leopardianas que já situam o princípio dessa barbárie no Renascimento, em virtude de suas características modernas, e aborda a nova relação estabelecida por Leopardi entre natureza e razão, objetivando indagar sobre a vitalidade das "novas" ilusões constituídas no mundo moderno. Retornam neste capítulo algumas reflexões de Leopardi sobre a razão iluminista e as suspeitas dele em relação ao progresso. Ademais, na sua abordagem sobre 0 individualismo moderno, Leopardi enfrenta 0 empobrecimento relativo ao indivíduo, por causa dos danos decorrentes da perda causada pelo fim das antigas ilusões.

O quarto e último capítulo [Leopardi e a problemática de uma moral moderna] aborda outras desvantagens, identificadas por Leopardi na Modernidade. A nova cultura oriunda da racionalidade moderna provocou uma espiritualização das forças, ou seja, um processo de racionalização que significou para o homem moderno fragilidade, se comparada à vitalidade dos antigos. Neste capítulo apresentam-se os novos saberes que provocam, ao mesmo tempo, uma crise do poético e a suspeita leopardiana em relação ao político como via de enfrentamento das desvantagens modernas. Retorna ainda um tratamento sobre a infelicidade do homem moderno, tendo como base as análises leopardianas da problemática da modernização, as quais conduzem a uma abordagem sobre o alerta de uma nova barbárie, isto é, a barbárie da sociedade.

Em conformidade com a disposição das hipóteses - acima indicadas destaca-se a Modernidade e a strage delle illusioni ${ }^{38}$, como argumento fundamental na reflexão leopardiana, quer em relação à vida civil quer em relação à condição humana. Contudo, a orientação ${ }^{39}$ aqui seguida enfatiza,

${ }^{38}$ A expressão leopardiana strage delle illusioni se apresenta no Discorso sopra lo stato presente dei costumi degl'italiani significando a perda e a destruição das ilusões vitais que constituíam a vida civil no mundo antigo. Tal strage decorre do uso excessivo da razão geométrica, da experiência do conhecimento da verdade e da forma específica de organização do estado político das sociedades modernas (Cf. LEOPARDI, Giacomo. Discorso sopra lo stato presente dei costumi degl'italiani [1824], Milano: BUR, 2006, p. 52.

39 Esta pesquisa reuniu um novo acervo dos estudos produzidos na Itália e fora dela, pertencente a orientações de diferentes pesquisadores. Nesse sentido pode-se aqui destacar os principais nomes que contribuem atualmente com o desenvolvimento da investigação sobre o pensamento de Leopardi. Entre estes estudiosos destacam-se aqui: Manfredi Porena (18731955), Sergio Solmi (1899-1981), Ana Dolfi, Ezio Raimondi, Gino Tellini, Augusto Placanica 
sobretudo, a strage delle illusioni na Modernidade e os seus efeitos na vida civil, ou seja, as degenerescências ocorridas no universo da vida dos indivíduos e na sua relação com a sociedade. Daí a necessidade de algumas indagações: para Leopardi, após essa destruição é possível ainda recuperar as antigas ilusões? A sociedade moderna oferece outras formas de ideais que possam substituí-las? Qual o resultado na vida civil do desaparecimento das ilusões no universo da subjetividade $\mathrm{e}$ do ethos? Como enfrentar 0 materialismo e o pessimismo leopardianos ante esse acontecimento? A strage delle illusioni e a modernização tornam-se, no domínio da reflexão leopardiana, um impedimento para um sentido prático? Se se considera a possibilidade da dimensão prática o que dizer da sua crítica à nova barbárie?

(1932-2002), Cesare Galimberti, Mario Andrea Rigoni, Fabio Russo, Marco Dondero, Lucio Felice, Gaspare Polizzi, Franco D'intino, Susanne Koopmann, entre outros. 


\section{PARTE I}

A ITÁLIA E A MODERNIDADE EUROPEIA: REFLEXÃO LEOPARDIANA 
um jornal deve promover, principalmente, 0 progresso e a propagação das ciências morais. Ora essas ciências e todas aquelas que hoje se compreendem sob o nome de Filosofia, parte principal do saber em todo o resto da Europa, e particularmente própria do nosso século, são, portanto, (...) o estudo menos cultivado na Itália; aliás, seriam aqui completamente ignoradas, se não fosse por meio dos livros estrangeiros e das traduções. De modo que querendo dar conta das produções recentes dos italianos, não haver-se-ia nunca campo para falar nem de moral nem de filosofia $(. . .)^{40}$.

Giacomo Leopardi. Epistolário

Em 1824, Gian Pietro Viesseux ${ }^{41}$, fundador e diretor da revista Antologia $^{42}$, publicada em Florença, e que defendia um renovamento cultural de orientação liberal $^{43}$, convidou Giacomo Leopardi a colaborar, convite que se renovou em 1826 e, dessa vez, para que ele mantivesse a rubrica intitulada "Hermite des Apennins" ${ }^{44}$. Tal rubrica devia informar aos leitores as condições

${ }^{40}$ LEOPARDI, Giacomo. Epistolario in: Tutte le poesie, tutte le prose e lo Zibaldone. Roma: Newton\&Compton, 1997, p. 1261: "un Giornale deve promuovere principalmente l' progresso e la propagazione delle scienze morali. Ora queste scienze e tutte quelle che oggi si comprendono sotto il nome di Filosofia, parte principale del sapere in tutto il resto d'Europa, e particolarmente propria del nostro secolo, sono appunto, [...] lo Studio meno coltivato in Italia, anzi sarebbero affatto ignote, se non fosse per mezzo de' libri stranieri e delle traduzioni. Di modo che volendo dar conto delle produzioni recenti degli italiani, non si avrebbe mai campo di parlare né di morale né di filosofia [...]".

${ }^{41}$ Segundo Damiani, Giordani no início de novembro de 1823 sugere a Leopardi um acordo de colaboração com Viesseux, diretor da Antologia, a melhor revista editada na Itália. Leopardi até aquele momento sabia com dificuldade o nome daquele homem de negócios, de origem suíça e de religião protestante. Viesseux teria se transferido em 1819 para Florença, onde havia aberto um Gabineto di Letteratura Scientifico-Letterario, inspirado justamente no modelo anglosaxão. Damiani escreve ainda que três vezes na semana se recolhiam nas salas do prédio Buondelmonti diversos literatos e estudiosos com índoles e interesses diversos, mas associados com base em uma orientação liberal (Cf. DAMIANI, Rolando. All'apparir del vero: vita di Giacomo Leopardi, pp. 222-223.

42 A Antologia perseguia uma finalidade moral, visando o aperfeiçoamento da sociedade. Podia-se contribuir com qualquer texto, igualmente as resenhas de livros italianos ou estrangeiros, que o jornal fornecia (Cf. DAMIANI, Rolando. All'apparir del vero: vita di Giacomo Leopardi, p. 224).

43 Ver, nesse sentido, DOTTI, Ugo. La radiografia leopardiana della società politica e intellettuale italiana. In: Lo Zibaldone cento anni dopo. Composizione,edizioni, temi. Atti del X Convegno Internazionale di studi leopardiani. Vol II. Set/1998, Recanati-Italia, Centro Nazioanle di Studi Leopardiani (CNSL), Firenze: OLSCHKI Editore, 2001, pp. 673-678.

${ }^{44}$ Rubrica proposta por Viesseux a Leopardi para colaborar com a Antologia, renunciada por Leopardi, conforme a carta de quatro de março de 1826. Ver, nesse sentido, SAVARESE, 
intelectuais e morais do Estado pontifício. Contudo, jamais ocorreu essa colaboração, pois Leopardi alegava a sua precária condição de saúde, que o impedia de participar como colaborador. Outros, porém, eram os motivos, ou seja, uma discordância relativa às ideias e princípios em relação ao programa da Antologia 45 : voltado para o "aperfeiçoamento do nosso estado social" [perfezionamento del nostro stato sociale] ${ }^{46}$. Leopardi parece fazer troça ao responder a Viesseux ${ }^{47}$ que é "ignorante" em filosofia social, mesmo sabendo de estudar, examinando a si mesmo, "o homem em si" [l'uomo in se $]^{48}$. Se a cultura do século XVIII propôs a ideia de progresso, essa ideia não já havia sido rechaçada por Leopardi nesse período? As Operette morali e o Zibaldone di pensieri não apresentariam várias formulações em que ele desacreditava os ideais de "aperfeiçoamento" e "melhoria" do estado social? ${ }^{49}$

Gennaro. L'eremita osservatore: saggio sui "Paralipomeni" e altri studi su Leopardi. Roma: Bulzoni, 1995, p. 211.

${ }^{45}$ Vale aqui destacar as observações de Tellini, pois sustenta o distanciamento de Leopardi com a orientação programático-econômica perseguida por Viesseux e da cultura liberal burguesa. Daí o estudioso se utilizar da carta enviada por Leopardi a Giordani, de 29 de julho de 1828 (Cf. TELLINI, Gino. Leopardi. Roma: Salerno Editrice, 2001, p. 162).

${ }^{46}$ LEOPARDI, Giacomo apud RAIMONDI, Ezio. Letteratura e identità nazionale, Milano: Bruno Mondadori, 1998, p. 35.

${ }^{47}$ Conforme Damiani, no início de fevereiro, enquanto concluía a Storia del genere umano, pertencente às Operette morali, Leopardi agradeceu a Viesseux pela oferta e que teria aceito de bom grado senão vivesse em um lugar periférico onde a leitura era muito rara. Sustentava ainda qua na Itália, diferentemente dos outros grandes países europeus, um jornal deveria ensinar o que deve ser feito, ao contrário de anunciar aquilo que se faz, pois com frequência se tratava de "tolices, barbárie e, sobretudo, velharias, cópias e repetições" [sciocchezze, barbarie, e sopratutto rancidumi, copie e ripetizioni]. Damiani diz ainda que Leopardi afirmava de não valer à pena que uma revista gastasse o seu papel para fazer resenha de um soneto ou "algum comentário sobre um livro antigo, sobre uma pedra, sobre uma moeda e coisas semelhantes" [qualche commentario sopra un libro antico, sopra un sasso, una moneta e cose simill]; (Cf. DAMIANI, Rolando. All'apparir del vero: vita di Giacomo Leopardi, p.224).

${ }^{48}$ Ibidem. Ainda em conformidade com Damiani, Leopardi aprovava a vontade de promover "o progresso e a propagação das ciências morais" [il progresso e la propagazione delle scienze morali], pois na Itália se conheciam apenas por meio de traduções e livros estrangeiros. Ele aconselhava também, a Viesseux, de exigir artigos originais que analisassem as melhores obras publicadas no exterior em uma perspectiva italiana, e que podia igualmente escrever algum artigo de argumento filosófico (Cf. DAMIANI, Rolando. All'apparir del vero: vita di Giacomo Leopardi, p. 224).

${ }^{49}$ Ver, nesse sentido, os seguintes diálogos das Operette morali: Dialogo di Ercole e di Atlante, pp. 92-93, 97; Dialogo della Moda e dalla Morte, pp. 105-107; Proposta di premi fatta dall'Accademia dei Sillografi, pp. 109-119; Dialogo della Natura e di un'Anima, pp. 141-149; Dialogo della Terra e della Luna, p. 163; La scommessa di Prometeo, pp. 182-183; Dialogo di un Fisico e di un Metafisico, pp. 191-209; Dialogo della Natura e di un Islandese, pp. 233-247; Parini, ovvero della gloria, pp. 249-295; Detti memorabili di Filippo Ottonieri, pp. 316, 324-326, 332-335, 337-341, 344; Dialogo di Timandro e di Eleandro, pp. 415-431; I/ Copernico, dialogo, pp. 446-451; Dialogo di Plotino e di Porfirio, pp. 455-483; Dialogo di un venditore d'almanacchi 
Não se sabe, ao certo, se o poeta tenha enviado à revista florentina esse artigo de "gênero filosófico", conforme esboça a carta lhe enviada por Viesseux, e se tal artigo consistia no Discorso sopra lo stato presente dei costumi degl'italiani de 1824. Há, porém, referências no Zibaldone di pensieri que fazem alusão à reflexão sobre esse tema que remontam a 1822: "Veja o esboço de meu discurso sobre os costumes presentes dos italianos" [Vedi l'abbozzo del mio discorso sopra i costumi presenti degl'italiani ${ }^{50}$. Ademais, o ano de 1824 indica também uma nova viragem ${ }^{51}$ na obra leopardiana. Leopardi abandonava, com efeito, na sua proposta de um "sistema da natureza" ${ }^{52}$, a relação anterior Natureza-razão, pressuposto dos primeiros anos, uma vez que a Natureza não seria mais a "mãe amorosa" [madre amorosa], mas uma "natureza madrasta" [natura matrigna], ou seja, responsável pelos males e pela infelicidade humana ${ }^{53}$. Onde buscar então um novo princípio após a strage delle illusioni?

e di un passeggere, pp. 485-492; Dialogo di Tristano e di un Amico, pp. 493-515 (Cf. LEOPARDI, Giacomo. Operette morali, a cura di Cesare Galimberti, Napoli: Guida, 1998 (5 ${ }^{\underline{a}}$ ed.). Destacam-se também, entre os vários momentos da crítica leopardiana à ideia de perfectibilidade humana, as seguintes passagens do Zibaldone di pensieri: Fragmentos, 222223, 23.08.1820; 393-420, 09-15.12.1820; 830-835, 21.03.1821; 940, 12-13.04.1821; 10961098, 27.05.1821; 1554-1562, 25.08.1821; 1570-1572, 27.08.1821; 1616-1620, 03.09.1821; 2392-2395, 05.03.1822 (Cf. LEOPARDI, Giacomo. Zibaldone di pensieri, in: Tutte le poesie, tutte le prose e lo Zibaldone, pp. 1539, 1575-1580, 1650-1651, 1673, 1708-1709, 1803-1804, 1805-1806, 1814-1815, 1942).

${ }^{50}$ Cf. LEOPARDI, Giacomo. Zibaldone di pensieri, fragmento 2618, 30.08.1822, in: Tutte le poesie, tutte le prose e lo Zibaldone, p. 1979.

51 Trata-se aqui da viragem filosófica ocorrida no desenvolvimento da obra de Leopardi, identificada pelos estudos leopardianos, no ano de 1819, pois representaria o ápice de uma crise vivenciada por ele em sentido existencial e de novas experiências intelectuais. Pertence justamente a esse período de 1819, no qual biografia e desenvolvimento intelectual se articulem sob a expressão de certo pessimismo, as primeiras alusões leopardianas ao seu projeto de compor "diálogos satíricos à maneira de Luciano". Segundo Leopardi, "extraídos os personagens e o ridículo dos costumes presentes, ou seja, modernos" [tolti i personaggi e il ridicolo dai costumi presenti o moderni]. Ver aqui LEOPARDI, Giacomo. Memorie e disegni letterari [1819-1834], in: Tutte le poesie, tutte le prose e lo Zibaldone, Roma: Newton\&Compton, 2010, p. 1109.

${ }^{52} \mathrm{Em} 15$ de maio de 1820, Leopardi fez uma terrível descoberta, devastadora de sua fé na bondade da natureza: a de que a contradição não pertence à razão, ou seja, de que a "perfeição da razão [perfezione della ragione] não significa "perfeição do homem" [perfezione dell'uomo], mas é inerente à natureza. "Quem sabe me explicar essa contradição na natureza?" [chi mi sa spiegare questa contraddizione in natura?]. Ver, nesse sentido, LEOPARDI, Giacomo. Zibaldone di pensieri, fragmento 4087, 11.05.1824, in: Tutte le poesie, tutte le prose e lo Zibaldone,p. 2280.

${ }^{53}$ Ver aqui LEOPARDI, Giacomo. Zibaldone di pensiere, fragmento 4129, 05-06.04.1825, in: Tutte le poesie, tutte le prose e lo Zibaldone, p. 2293. 


\section{CAPÍTULO I}

\section{Leopardi e os costumes dos italianos: abordagem da modernização do Discorso de 1824}

Della natura degli uomini e delle cose. Conterrebbe la mia metafísica, o filosofia trascendente, ma intelligibile a tutti, ma intelligibile a tutti. Dovrebbe essere l'opera della mia vita.

G.Leopardi. Memorie e disegni letterari ${ }^{54}$

Galateo morale: cioè dei rispetti che bisogna avere nella conversazione e nel viver civile, per non offendere certe passioni degli uomini, in certe maniere, poco osservate.

G. Leopardi. Memorie e disegni letterari ${ }^{55}$

Em 1824, Leopardi se depara com uma confluência, quer de acontecimentos históricos quer de outras experiências culturais: algo relevante que marca a sua experiência na sociedade moderna. Se, de um lado, após o fracasso da Revolução moderna, dá-se ao mesmo tempo a ruína das ilusões revolucionárias modernas e o advento da Restauração ${ }^{56}$, de outro, vê-se

${ }^{54}$ Cf. LEOPARDI, Giacomo. Memorie e disegni letterari [1819-1834], in: Tutte le poesie, tutte le prose e lo Zibaldone, p. 1112.

${ }^{55}$ Cf. LEOPARDI, Giacomo. Memorie e disegni letterari [1819-1834], in: Tutte le poesie, tutte le prose e lo Zibaldone, p. 1112.

56 Sobre a Restauração Asor Rosa comenta: "Como sempre ocorre em todos os acontecimentos históricos de dimensão ciclópica - e a Restauração certamente o foi - a determinar as saídas e as características, sem contar com a desastrosa derrota do exército napoleônico em Waterloo, concorreram várias motivações. Não há dúvida [...] que tiveram um papel relevante o cansaço de duas décadas de guerra quase ininterruptas, o desgaste da motivação revolucionária originária, o sofrimento pelo domínio francês, que [...] havia se manifestado com freqüência em toda Europa como um estado de ocupação ávido e opressor. Também no campo das idéias não é insignificante o efeito de retorno que se produziu quando a tríade ideológica 'liberdade, igualdade, fraternidade' demonstrou [...] de não estar efetivamente radicada na prática dos grupos sociais e dos Estados contemporâneos e de ter se tornado, ao contrário, uma pura bandeira vagamente programática, a agitar apenas nos momentos mais convenientes. A experiência ensina que, quando um processo revolucionário não produz os seus efeitos nem no campo da teoria nem no campo da prática, reafirmam-se os princípios opostos, aqueles que [...] pareciam apagados em todo lugar e para sempre. Também a este contragolpe [...] deve-se a verdadeira e própria onda de sentimento religioso que invade a Europa nesta fase e caracteriza tantas manifestações literárias e culturais do período" (Cf. ROSA, Asor. Storia europea della letteratura italiana. II - Dalla decadenza al Risorgimento. Torino: Einaudi, 2009, pp. 406-407). Salvatorelli comenta também a passagem do período napoleônico à Restauração, ver aqui: SALVATORELLI, Luigi. II pensiero político italiano: dal 1700 al 1870. Torino: Einaudi, 1941 (2 ed.), pp. 143-189; Sobre o que significou em termos 
atenuar a hegemonia cultural da França e com a Alemanha impôs-se na Europa uma nova religião, a da razão elevada à metafísica ${ }^{57}$. O Discorso sopra lo stato dei costumi degl'italiani é um diagnóstico da situação econômica, social, cultural e política italiana, ante a modernização europeia. Em tal diagnóstico o pressuposto da civilização clássica - com a particularidade de seu ethos - assume uma dimensão de eticidade e orientação para uma reflexão ética e política sobre as transformações do mundo moderno.

\subsection{A Itália e as outras nações europeias: a análise leopardiana}

Em sua análise sobre o processo modernização das nações europeias, e daquela italiana, considera-se aqui como relevantes os argumentos pertencentes ao Discorso sopra lo stato presente dei costumi degl'italiani ${ }^{58}$, obra de 1824, em que Leopardi reflete sobre a especificidade da modernização

sociais a Restauração na Itália e quem eram os seus representantes, ver ainda LUPORINI, Cesare. Leopardi progressivo [1947]. Roma: Riuniti, 2006, p. 90.

${ }^{57}$ Ver, nesse sentido, a nota 50 em LEOPARDI, Giacomo. Discorso sopra lo stato presente dei costumi degl'italiani [1824], in: Tutte le poesie, tutte le prose e lo Zibaldone, p. 1024. Sobre o período de 1824, ver comentário: PLACANICA, Augusto. Leopardi, o della modernità in: LEOPARDI, Giacomo. Discorso sopra lo stato presente dei costumi degl'italiani, Venezia: Marsilio editori, 1992, p. 34. Pode-se identificar ainda no Zibaldone di pensieri alguns comentários sobre a filosofia alemã. Ver, nesse sentido, LEOPARDI, Giacomo. Zibaldone di pensieri, fragmento 2618, 30.08.1822, in: Tutte le poesie, tutte le prose e lo Zibaldone, p. 1979.

58 LEOPARDI, Giacomo. Discorso sopra lo stato presente dei costumi degl'italiani [1824]. Milano: BUR, 2006. De um ponto de vista "formal", Mario Andrea Rigoni afirma que o Discorso leopardiano entra na história de um pequeno "gênero" literário, a saber, o da descrição dos caracteres e costumes dos italianos. Estão inscritos na história deste tratamento autores como Pietro Calepio, Giuseppe Baretti e Carlo Denina, mas também Gozzi, Parini e Goldoni. Leopardi lamentava, nestes últimos, a ausência de teor filosófico e de reflexões, pois não teriam sido essas "a intenção e a natureza de seus escritos". Quanto aos primeiros, ele menciona apenas Baretti, destacando, entretanto, as suas limitações, em virtude de não acompanhar em suas considerações as significativas mudanças ocorridas nos costumes, ou seja, desde antes da Revolução francesa até os tempos presentes. Rigoni destaca o fato de Leopardi não ignorar a existência de uma vasta literatura estrangeira sobre o tema, sobretudo, inglesa e francesa. Fruto do tradicional tour à Itália, quase obrigatório entre os intelectuais europeus dos séculos XVIII e XIX, tal gênero remontaria a Montaigne (Journal de voyage en Italie, publicado apenas em 1774), chegando até o presente leopardiano com o louvável romance de Mme. De Staël (Corinne ou l'Italie, de 1807): obra citada várias vezes por Leopardi no Zibaldone, da qual deriva o argumento central do Discorso", a saber, a inexistência de sociedade na Itália. (Cf. RIGONI, Mario Andrea. Leopardi e i costumi degli italiani, in: LEOPARDI, Giacomo. Discorso sopra lo stato presente dei costumi degl'italiani, pp. 6-9.). Acerca da influência de Mme. de Staël sobre o Discorso leopardiano de 1824, ver também MELCHIORI, Roberto. Commento, in: LEOPARDI, Giacomo. Discorso sopra lo stato presente dei costumi degl'italiani, nota 7, p.87. Para uma reflexão mais aprofundada acerca das teorias filológicas sobre a datação do Discorso leopardiano, ver as seguintes obras: SAVARESE, Genaro. L'eremita osservatore. Saggio sui "Paralipomeni" e altri studi su Leopardi. Roma: Bulzoni, 1995; DONDERO, Marco. Leopardi e gli italiani. Ricerche sul "Discorso sopra lo stato presente dei costumi degl'Italiani". Napoli: Liguori, 2000. 
da Itália em comparação às outras nações: Alemanha, Inglaterra e França. No Discorso, Leopardi principia comentando que, após o término daquele vendaval representado pela Revolução francesa e pelas incursões napoleônicas, o avanço dessas nações e suas conquistas nos domínios econômicos, culturais, literários, civis e militares, possibilitaram entre elas certa "igualdade de reputação" [uguaglianza di riputazione], pois na época da difundida e estabelecida civilização européia, a saber, aquela de Luís XIV, todas as nações haviam espontaneamente cedido honras à França, que a todas desprezava ${ }^{59}$. Nesse presente século, Leopardi escreve no Discorso,

por causa de alguma ou por todas essas razões as nações civis da Europa, ou seja, principalmente a Alemanha, a Inglaterra e a própria França abdicaram (talvez também pelo progresso das Luzes e do espírito filosófico e raciocinante, que aumenta as luzes e acalma as paixões e introduz um hábito de moderação; e igualmente pelo próprio enfraquecimento do amor e fervor nacional, e geralmente de todas as paixões dos homens), digo, abdicaram de grande parte dos antigos preconceitos nacionais desfavoráveis aos forasteiros, da animosidade, da aversão em direção a eles e, sobretudo, do desprezo contra os mesmos e contra a literatura, civilização e costumes deles, ainda que se queira diferentes das deles. E aumentando o gosto de conhecê-los, ao mesmo tempo com a estima dos mesmos e com a equidade no julgá-los, ilimitados são os volumes publicados por cada nação para informá-la das coisas das outras ${ }^{60}$.

As razões indicadas por Leopardi, para esses avanços, vão desde a comunhão de desventuras promovidas pelas guerras napoleônicas, que estabeleceu certo equilíbrio militar entre as nações, o estreitamento das

\footnotetext{
${ }^{59}$ Bem diferente é a situação da nação francesa iluminista, pois, menos intolerante e, em certo sentido, ao pretender fazer justiça às coisas estrangeiras, mesmo após a derrota do exército napoleônico, permaneceu, em parte, ainda como modelo moderno de uma "Europa civil" (Cf. LEOPARDI, Giacomo. Discorso sopra lo stato presente dei costumi degl'italiani, nota a, p.45).

${ }^{60}$ LEOPARDI, Giacomo. Discorso sopra lo stato presente dei costumi degl'italiani, pp. 45-47: "per qualcuna o per tutte queste cagioni le nazioni civili d"Europa, cioè principalmente la Germania, l'Inghilterra e la Francia stessa hanno deposto (forse anche pel progresso dei lumi e dello spirito filosofico e ragionatore che accresce i lumi e calma le passioni ed introduce uno abito di moderazione; e altresì per l'affievolimento stesso dell'amore e fervor nazionale, e generalmente di tutte le passioni degli uomini) hanno, dico, deposto gran parte degli antichi pregiudizi nazionali sfavorevoli ai forestieri, dell'animosità, dell'avversione verso loro, e soprattutto del disprezzo verso i medesimi e verso le loro letterature civiltà e costumi, quantunque si voglia differenti dai propri. E cresciuto il gusto di conoscerli insieme colla stima de' medesimi e colla equità del giudicarli, infiniti sono i volumi pubblicati in ciascuna nazione per informarla delle cose dell'altre".
} 
relações de comércio, o uso de viagens, até o incremento da literatura e do saber filosófico, em especial, o enciclopédico. Essas conquistas justificam também o abandono dos antigos preconceitos nacionais e da animosidade, aversão e desprezo pelas diferentes culturas ${ }^{61}$.

Não obstante essas conquistas, o aumento do interesse pela língua, literatura e civilização estrangeiras como um avanço entre as nações européias, Leopardi observa certas consequências negativas de tal processo. O progresso do "espírito filosófico e raciocinador" [spirito filosofico e ragionatore], ao introduzir certo hábito de moderação nos homens, é considerado pelo autor como a principal causa do crescimento das "luzes" [lumi] e do abrandamento do "amor e fervor nacional" [amore e fervor nazionale], mas também do enfraquecimento "de todas as paixões dos homens" [di tutte le passioni degli uomini] ${ }^{62}$. Ele percebeu que a presença do "juízo raciocinado e desapaixonado" [giudizio ragionato e spassionato], fruto do "espírito filosófico e justo" [spirito filosofico e giusto], tornou-se universal em seu tempo: uma experiência sem precedentes na história ${ }^{63}$. Disso resulta a constatação de Leopardi, conforme expõe na nota:

Além de todo o resto, a vida, a imaginação, e na literatura a originalidade e novidade, em suma, tudo aquilo que serve para alimentar a vida humana e escapar ao tédio, e ocupar de algum modo quem não tem necessidades, embora seja desigualmente distribuído, é, contudo, tão escasso junto às nações, ainda que mais disso excedam, que todas estão agora direcionadas para recolher sarmentos, por assim dizer, de toda parte para reparar a frieza que ocupa geralmente a vida moderna civil, e para formar das poucas chamas esparsas aqui $e$ ali $e$ insuficientes a cada um, como um fogo comum que seja menos inferior à necessidade que todos têm de calor, e

${ }^{61}$ Cf. LENTZEN, M. I tedeschi e la Germania nello "Zibaldone" di Giacomo Leopardi. In: II pensiero storico e político di Giacomo Leopardi. Atti del VI Convegno Internazionale di studi leopardiani. Vol II. Set/1984, Recanati-Italia, Centro Nazioanle di Studi Leopardiani (CNSL), Firenze: OLSCHKI Editore, 1989, pp. 319-328; MAZZALI, Ettore. La società italiana contemporanea e il Leopardi. In: II pensiero storico e político di Giacomo Leopardi, pp. 349-355; MUSUMARRA, Carmelo. Leopardi e i "fatti" della storia. II pensiero storico e político di Giacomo Leopardi. pp. 391-397.

${ }^{62}$ Cf. LEOPARDI, Giacomo. Discorso sopra lo stato presente dei costumi degl'italiani. p. 46.

${ }^{63}$ Ver BISCUSO, M. GALLO, F. Leopardi antitaliano, Roma, Manif, 1999. 
reunir ao mesmo tempo todo aquele pouco de vida que em todas as partes se encontra ${ }^{64}$.

Para Leopardi, "a originalidade, a imaginação e a invenção estão extintas em toda Europa" ${ }^{25}$; daí todo o mundo imitar, colecionar, compilar e dissertar sobre as coisas encontradas por outros, sejam elas antigas sejam modernas. A criação chegou ao fim ou se tornou escassa. Tais argumentos não se limitam à questão literária, pois, no seu entender, são igualmente válidos para os costumes e as opiniões. Entre tantos volumes publicados pelos estrangeiros destacam-se, igualmente, como escreve Leopardi, aqueles sobre "as coisas da Itália. [le cose d'Italia] ${ }^{66}$ : objeto de curiosidade geral e de viagens, como em nenhuma outra época, e mais do que qualquer outro país.

Nesse empreendimento revelam-se, porém, conforme adverte Leopardi, duas "desvantagens" [inconvenient], decorrentes da natureza do tema e não por culpa dos escritores:

64 Ibidem: "Oltre a tutto il resto, la vita, l'immaginazione, e nella letteratura l'originalità e nvità, insomma tutto quello che serve a pascere la vita umana e scacciar la noia, ed occupare in qualche modo chi non ha bisogni, benchè sai inegualmente distribuito, è però cosi scarso presso le nazioni ancora che più ne abbondano, che tutte sono ora rivolte a raccogliere sermenti per cosi dire da ogni parte onde riparare alla freddezza che occupa generalmente la vita moderna civile, e a formare delle poche fiamme sparse qua e là e insufficienti a ciascuno, come un fuoco comune che sia manco inferiore al bisogno che tutti hanno di calore, e adunare insieme tutto quel po' di vita che in tutte le parti si trova". Quando Leopardi fala da inclinação do homem ao infinito, diz existir no homem, independente do desejo de prazer, a faculdade da imaginação. Tal força imaginativa pode representar prazeres que não existam de fato, e representá-los de forma infinita, seja em número seja em duração seja em extensão. Desse modo o prazer infinito que não se pode encontrar na realidade, encontra-se assim na imaginação: fonte da esperança e das ilusões. Não é de se admirar, segundo Leopardi, que a esperança seja sempre maior do que o bem, e a felicidade não consistir senão na imaginação e nas ilusões. Por isso essa faculdade é a primeira fonte da felicidade humana e enquanto ela reinar no homem, ele será sempre feliz. Por conseguinte, aquilo que pertence ao imaginário tem forças mais naturais, e a natureza é sempre superior à razão. Porque os bens parecem muito belos e grandiosos à distância e o desconhecido mais belo do que o conhecido, isso é fruto da imaginação decorrente da inclinação natural ao prazer, assim como efeito das ilusões permitido pela natureza (Cf. LEOPARDI, Giacomo. Zibaldone di pensieri, in: Tutte le poesie, tutte le prose e lo Zibaldone, fragmentos 165-168, 12-13.07.1820; 176-177, 12-23.07.1820, pp. 1523-1524, 1526-1527).

${ }^{65}$ Ibidem, p. 47. Giambattista Vico já havia identificado o esgotamento do ingenium na Europa - como revela o seu Epistolário -, pois afetava todos os gêneros de ciência. Tal esgotamento decorria, no seu entender, do predomínio do método de Descartes, uma vez que todos haviam aplicado os engenhos com esse método, pelo qual são compensados apenas com clara e distinta percepção. Com argumentos anticartesianos, Vico apresenta um diagnóstico dos rumos tomados pela racionalidade e pelos danos causados ao saber e à criação. Ver, nesse sentido, VICO, Giambattista. Lettere, in: Opere, tomo I, Milano: Mondadori, 1990, pp. 323-336.

${ }^{66}$ Cf. LEOPARDI, Giacomo. Discorso sopra lo stato presente dei costumi degl'italiani. p. 47. 
uma que, com frequência erram, sendo impossível para um estrangeiro conhecer perfeitamente uma outra nação, não mais senão após longa estada, a outra que, dizendo ou o falso, ou também o verdadeiro, que seja um pouco desfavorável para aqueles de quem falam, ainda que o digam sem nenhuma animosidade [...] provocam o ódio da nação de que escrevem ${ }^{67}$

A segunda desvantagem, a mais grave, se apresenta nos livros que tratam dos italianos: argumento que prepara a análise leopardiana da situação da Itália ante as nações europeias.

Para Leopardi parece estranha a delicadeza com a qual os escritores estrangeiros se reportam aos italianos, em especial, se se considera a quase inexistência de "amor nacional" [amor nazionale] entre eles: menor que em outros países. Isso explica igualmente o modo como os italianos concebem os outros povos:

medindo os outros com base em si mesmos, (os quais caminhando sempre atrás dos outros, não estão ainda tão distantes dos preconceitos e da animosidade contra os estrangeiros, e certamente os conhecem e se esforçam em conhecê-los cem vezes menos do que eles não fazem em relação a eles [italianos] $)^{68}$.

Leopardi assegura que o ódio ou o desprezo contra outras nações, quer nos livros quer em outras formas estão "fora de moda" [fuor di moda] ${ }^{69}$.

Em seu Discorso, Leopardi constata no mundo civil europeu ${ }^{70}$ uma grande inclinação - mais do que em qualquer época e algum outro país - a

\footnotetext{
${ }^{67}$ Ibidem, pp. 47-48: "l'uno che spesso errano, essendo impossibile a uno straniero il conoscere perfettamente un'altra nazione, massime dopo non lunga dimora, l'altro che dicendo o il falso, o anche il vero, che sai alcun poco sfavorevole a quelli di cui parlano, benché il dicano senz'animosità veruna [...] si concitano l'odio della nazione di cui scrivono".

${ }^{68}$ Ibidem, p. 48: "misurando gli altri da se medesimi (i quali comminando sempre addietro degli altri, non sono ancora così lontani da' pregiudizi e dall'animosità verso gli stranieri, e certo li conoscono e studiano di conoscerli cento volte meno che essi non fanno verso loro)".

69 Ver a nota C do Discorso leopardiano: LEOPARDI, Giacomo. Discorso sopra lo stato presente dei costumi degl'italiani. p. 48.

${ }^{70}$ Certamente Leopardi conheceu - como atestam alguns fragmentos do seu Zibaldone di pensieri - a chamada trattatistica renascentista do mundo civil. São diálogos e tratados que apresentavam uma preocupação em comum: falar do homem na sua convivência cotidiana e das regras adotadas no trato civil. Nessas obras prevaleceu uma orientação retórica dirigida à vida associada. Os trattatisti são, portanto, herdeiros dessa orientação retórica em que, no domínio da cultura humanística, a Retórica se apresentava como arte que une os homens e se encontra na base dos studia humanitatis. Entre esses trattatisti pode-se aqui indicar: Baldassar Castiglione (1478-1529) e sua obra // cortegiano (1528); Giovanni Pontano (1426-1503) e seu
} 
opiniões vantajosas em relação aos italianos. Todavia, quer Corinne ${ }^{71}$ quer outras obras provocaram, ao contrário, o ciúme [gelosia] nos italianos. Daí porque inúmeras coisas "verdadeiras" [vere] e "úteis" [utill] sobre os costumes desse povo terminassem sem qualquer utilidade. Contudbno, assevera Leopardi, os italianos "não escrevem nem pensam sobre os seus costumes, como sobre qualquer outra coisa que importe e beneficie a eles ou aos outros: exceto talvez apenas o Baretti" ${ }^{72}$.

Opondo-se a Baretti, Leopardi reconhece a mudança, após a Revolução, dos costumes e do estado presente da Itália, sobretudo, na Itália meridional, que se encontravam ainda nos costumes como em grande parte a Espanha. Para os franceses, conforme o Discorso, a Itália encontra-se, quanto às opiniões, à altura dos outros povos, não obstante uma maior confusão nas ideias, e uma menor difusão de conhecimento nas classes populares [una maggior confusione nelle idee, ed una minor diffusione di cognizioni nelle classi popolari] ${ }^{73}$.

escrito De Sermone (1499), Giovanni della Casa (1503-1556) e seu Galateo ovvero de' costumi (1558); Stefano Guazzo (1530-1593) e sua obra Civil conversatione (1574) e Giambattista Giraldi Cinzio (1504-1573) e seu Discorso intorno a quello che si conviene a Giovane nobile e ben creato nel servire un gran Principe (1565). Destacam-se, no Zibaldone, fragmentos relacionados a Baldassar Castiglione e Giovanni della Casa. Predominam, no entanto, os fragmentos relativos à Giovanni della Casa. Sobre Baldassar Castiglione ver no Zibaldone os seguintes fragmentos, 2682, 15.03.1823; 2796, 19.06.1823; 3132, 5-11.08.1823; 4231-4232, 12.12.1826, pp. 1990, 2009, 2071, 2326-2327; Sobre Giovanni Della Casa ver também no Zibaldone os fragmentos, $61,08.01 .1820 ; 230-321,13.11 .1820 ; 2268,21.12 .1821 ; 2414$, 02.05.1822; 2496, 24.06.1822; 2516-2517, 29.06.1822; 2536-2537, 30.06-02.07.1822; 4357, 29.08.1828; 4481, 03.04.1829, pp. 1493-1494, 1540-1559, 1920, 1946, 1960, 1964, 1966-1967, 2366, 2401 (Cf. LEOPARDI, Giacomo. Zibaldone di pensieri, in: Tutte le poesie, tutte le prose e lo Zibaldone).

${ }^{71}$ Quanto aos interesses e impressões de escritores estrangeiros em relação à Italia, Leopardi destaca a obra Corinne ou l'ttalie, de Madame de Staël, fruto de duas viagens da autora à Italia de dezembro de 1804 a junho de 1805 e de dezembro de 1815 a maio de 1816 . Essa obra representa, conforme o escrito leopardiano, um marco em relação às obras favoráveis à Itália e publicados nos outros anos.

72 Ibidem, pp. 48-49: "non iscrivono né pensano sui loro costumi, come sopra niun'altra cosa che importi e giovi ad essi o agli altri: eccetto forse il solo Baretti [...]". Leopardi considera ser Baretti um espírito mais falso que original. Sobre essa crítica leopardiana a Baretti, ver LEOPARDI, Giacomo. Discorso sopra lo stato presente dei costumi degl'italiani, p. 49.

${ }^{73}$ Cf. LEOPARDI, Giacomo. Discorso sopra lo stato presente dei costumi degl'italiani, p. 49. 


\subsection{Società strette e vida civil na Itália e nas outras nações europeias}

Após comentar as impressões dos escritores estrangeiros da Itália e os limites da análise de Baretti, e a quase ausência de tratados entre os italianos sobre os seus costumes, Leopardi se propõe analisar os "presentes costumes" [presenti costumi] ${ }^{74}$ com a mesma "sinceridade e liberdade" [sincerità e liberta ${ }^{75}$ com que realizaria um estrangeiro, e pretende fazê-lo com a certeza de não ser repreendido pelos italianos. Isso porque não poderão acusá-lo de "ódio" [odio] ou "emulação nacional" [emulazione nazionale] ${ }^{76}$. Julgar-se-ia, talvez, serem as coisas mais conhecidas para um italiano do que para um estrangeiro. Ademais, escreve Leopardi: "por que eu deverei falar com cerimônia à minha própria nação, isto é, quase à minha família e aos meus irmãos?"77

Ao escrever esse Discorso, Leopardi tem consciência dos danos da idade presente, frutos da modernização. Ele sabe ser difícil "dissimular" [dissimulare], considerando-se o estado presente dos povos" [lo stato presente dei popoli],

a extinção quase universal ou o enfraquecimento das crenças sobre as quais se pode fundamentar os princípios morais, e de todas aquelas opiniões fora das quais é impossível que o justo e o honesto pareça razoável, e o exercício da virtude, digno de um sábio, e, de outro lado, a inutilidade da virtude e a utilidade resoluta do vício dependentes da constituição política das presentes repúblicas ${ }^{78}$.

Por causa desse vazio deixado pelo desaparecimento dos ideais que fundamentavam a moral, Leopardi observa a sociedade, afirmando parecer a conservação dela "obra mais do acaso que de outra causa, e é

${ }^{74}$ Ibidem.

${ }^{75}$ Ibidem.

${ }^{76}$ Ibidem.

77 Cf. LEOPARDI, Giacomo. Discorso sopra lo stato presente dei costumi deglitaliani, p. 50: "perché dovrò io parlare in cerimônia alla mia própria nazione, cioè quase alla mia famiglia e a' miei fratelli?".

${ }^{78}$ Ibidem: "la quase universale estinzione o indebolimento delle credenze su cui si possano fondare i principii morali, e di tutte quelle opinioni fuor delle quali è impossibile che il giusto e l'onesto paia ragionevole, e l'esercizio della virtù degno d'un savio, e da altra parte l'inutilità della virtù e la utilità decisa del vizio dipendenti dalla política costituzione delle presenti repubbliche". 
verdadeiramente maravilhoso que ela possa ter lugar entre indivíduos que continuamente se odeiam, armam ciladas e buscam de todos os modos prejudicarem uns aos outros" ${ }^{\prime 79}$.

Trata-se aqui da constatação de que na idade presente parece ser 0 "vínculo" [vincolo], o "freio das leis e da força pública" [freno delle leggi e della força pubblica] como aquilo que resta para a sociedade, não obstante se reconhecer como algo muito insuficiente para conter o mal e ainda mais para estimular o bem. Leopardi se serve do pensamento de Horácio de que "as leis sem os costumes não bastam, pois [...] os costumes dependem e são determinados e fundados principalmente e garantidos pelas opiniões" ${ }^{\prime \prime 0}$.

Essa completa "dissolução dos princípios sociais" [dissoluzione dei principii socialli ${ }^{81}$ se apresenta, para Leopardi, como um caos que espanta realmente "o coração de um filósofo" [il cuor di un filosofo] ${ }^{82}$. Disso decorre igualmente a dúvida ante "o futuro destino das sociedades civis" [il futuro destino delle società civill] ${ }^{83}$. Trata-se aqui da "grande incerteza de como elas possam continuar a existir doravante" ${ }^{84}$. Leopardi reconhece, porém, que outras nações civis, sobretudo, "a França, a Inglaterra e Alemanha têm um princípio conservador da moral e, portanto, da sociedade, que embora pareça mínimo, e quase desprezível em comparação com os grandes princípios morais e de ilusão que se perderam, contudo é de uma grande validez. Esse princípio é a própria sociedade" 85 .

\footnotetext{
79 Ibidem: "opera piuttosto del caso che d'altra cagione, e riesce veramente maraviglioso che Ella possa aver luogo tra individui che continuamente si odiano s'insidiano e cercano in tutti $\mathrm{i}$ modi di nuocersi gli uni agli altri”.

80 Ibidem: "le leggi senza i costumi non bastano, e [...] che i costumi dipendono e sono determinati e fondati principalmente e garantiti dalle opinioni".

${ }^{81}$ Ibidem.

82 Ibidem.

${ }^{83}$ Ibidem.

${ }^{84}$ Ibidem.

${ }^{85}$ Ibidem: "la Francia, l'Inghilterra e la Germania, hanno un principio conservatore della morale e quindi della società, che benché paia minimo, e quase vile rispetto ai grandi principii morali e d'illusione che si sono perduti, pure è d'un grandíssimo effetto. Questo principio è la società stessa". Mario Andrea Rigoni, em seu escrito La strage delle ilusioni, defende uma concepção filosófica de teor histórico e político em Leopardi, não menos ampla que os aspectos metafísicos e estéticos de seu pensamento, com os quais, ao mesmo tempo, resulta "coordenada e solidária". Essa filosofia tem como base uma diagnose da civilização, segundo a
} 
Ao defender ser esse princípio a sociedade mesma, Leopardi identifica, reportando-se à França, Inglaterra e Alemanha que essas nações, além de tomadas com base em uma compreensão geral de como se constitui a sociedade, ou seja, na "convivência dos homens para prover reciprocamente às próprias necessidades, e defender-se dos comuns danos e perigos, têm aquele gênero mais particular de sociedade que costuma ser chamado com o mesmo nome reduzido com a significação mais estreita" ${ }^{86}$. Para explicar a disposição das classes e dos indivíduos nessa sociedade estreita, Leopardi escreve:

consiste em um comércio mais íntimo dos indivíduos entre eles, e sobretudo daqueles que, dispensados da condição deles de prover com a obra mecânica das próprias mãos à subsistência deles e a dos outros e providos do necessário à vida por meio das fadigas dos outros, faltando necessidades primárias, dirigem-se naturalmente na necessidade secundária, ou seja, de encontrar qualquer outra ocupação que preencha a vida deles, e os alivie o peso da existência, sempre pesada e intolerável quando é desocupada. Essa tal sociedade que está

qual, a condição natural do homem e do mundo teria sido irremediavelmente destruída por um processo de espiritualização universal, representado pelo "nefasto desenvolvimento da consciência, da interioridade, do saber e da ciência". Conforme Rigoni, em termos ideais e absolutos, esse evento seria correlato à "culpa originária", e, em termos históricos e relativos, a uma multiplicidade de fenômenos, em especial, o fim da Antiguidade e o advento do Cristianismo. Tal concepção se aprofundaria em Leopardi sob a "identidade de progresso e decadência, avanço e destruição, verdade e impotência, consciência e nulidade": algo já presente em Bayle e no lluminismo francês. "[...] a presença da razão é paralisante tanto para os singulares quanto para os grupos de qualquer espécie (os partidos, as escolas, as seitas), que apenas pelo preconceito extraem a força e a eficácia do seu agir, a premissa necessária a toda forma de empreendimento e de afirmação. A mesma lei vale para as sociedades e para os Estados, que devem sua fundação, conservação e prosperidade unicamente ao impulso fecundo do erro e da ilusão, ao providencial ofuscamento garantido pela natureza, enquanto são comprometidos e devastados, em toda época da história, pela expansão das Luzes: exemplo máximo a quebra da potência imperial romana. Que a infiltração da filosofia grega, acompanhada pela erosão da força religiosa, tenha sido 'causa da ruína de Roma vencedora do mundo', era uma idéia comum a muitos pensadores políticos do século XVIII e do início do século XIX, também muito diversos entre si, como Lamennais, Bolingbroke e Montesquieu, que Leopardi os põe todos juntos [...], embora observe precisamente que os Estados não sejam 'estabelecidos e conservados pela verdade, e destruídos pelo erro', como sustentam os apologistas da religião, mas 'estabelecidos e conservados pelo erro, e destruídos pela verdade" (Cf. RIGONI, Mario Andrea. La strage delle illusioni: pensieri sulla politica e sulla civiltà. Milano: Adelphi. 1993 (2 $2^{\mathrm{a}}$ ed.), pp. 9-38.). Quanto à noção de real como "deserto" e a consequente situação atópica do homem moderno ante a natureza e a sociedade, ver aqui BIRAL, Bruno. $L a$ posizione storica di Giacomo Leopardi. Torino: Einaudi, 1997 (5ae ed.), pp. 175-180.

${ }^{86}$ Cf. LEOPARDI, Giacomo. Discorso sopra lo stato presente dei costumi degl'italiani, pp. 5051: "convitto degli uomini per provvedere scambievolmente ai propri bisogni, e difendersi da' comuni danni e pericoli, hanno quel genere più particolare di società che suole essere chiamato con questo medesimo nome ridotto a significazione più stretta". 
principalmente entre esses tais homens, tem como fim o deleite e o preenchimento do vazio da vida ocasionado pela falta das necessidades primárias, e por causa há as ditas necessidades secundárias, como aquele outro mais amplo e mais comum gênero de sociedade tem por origem as necessidades primárias e a necessidade natural ${ }^{87}$.

$\mathrm{Na}$ ausência dos antigos princípios e vínculos, Leopardi reconhece que no presente, por meio da "sociedade estreita" [società stretta], as cidades e inteiras nações de "agregado" [aggregato] ${ }^{88}$ entre várias nações civis, tornamse "quase uma família" [quase una familia] ${ }^{89}$. Isso ocorre para que as nações juntas possam encontrar

nas relações mais estreitas e mais frequentes que nascem dessa quase união doméstica, uma ocupação, um pasto, um entretenimento para a vida daqueles, que sem isso, transcorreriam o tempo totalmente vazio, e tais são [...] todos os homens, salvo os agricultores e aqueles que nos obtém o vestido de primeira necessidade ${ }^{90}$.

No trato recíproco, os homens adquirem estima uns pelos outros. Para Leopardi, a "sociedade estreita" [stretta società] possibilita que cada um tenha em conta o outro e deseje fazer-se estimar, tendo os outros como necessários à própria felicidade. Tal satisfação do "amor próprio", que cada um espera, deseja e busca não pode ser encontrado em outro lugar a não ser na "sociedade estreita". Tal desejo, Leopardi chama de "ambição" [ambizione] ${ }^{91}$ : vínculo e sustentação da sociedade oriunda dessa forma de sociedade, ou

${ }^{87}$ Cf. LEOPARDI, Giacomo. Discorso sopra lo stato presente dei costumi degl'italiani, p. 51: "consiste in un commercio più intimo degl'individui fra loro, e massime di quelli, che dispensati dalla loro condizione dal provvedere coll'opera meccanica delle proprie mani alla loro e all'altrui sussistenza e forniti del necessário alla vita com mezzo delle fatiche altrui, mancando de' bisogni primi, vengono naturalmente nel secondo bisogno, cioè di trovare qualche altra occupazione che riempia la loro vita, e alleggerisca loro il peso dell'esistenza, sempre grave e intollerabile quando è disoccupata. Questa tal società che è principalmente fra questi tali uomini, ha per fine il diletto e il riempire il vuoto della vita cagionato dalla mancanza de' bisogni primi, e per causa ha i detti bisogni secondi, come quell'altro più largo e più comun genere di società ha per origine i primi bisogni e la naturale necessita".

${ }^{88}$ Cf. LEOPARDI, Giacomo. Discorso sopra lo stato presente dei costumi degl'italiani, p. 51.

${ }^{89}$ Cf. LEOPARDI, Giacomo. Discorso sopra lo stato presente dei costumi degl'italiani, p. 51.

${ }^{90}$ Cf. LEOPARDI, Giacomo. Discorso sopra lo stato presente dei costumi deglitaliani, p. 51: "nelle relazioni più strette e più frequenti che nascono da tale quase domestica unione, una occupazione, un pascolo, un trattenimento alla vita di quelli, che senza cio menerebbero il tempo affatto vuoto, e tali sono, rigorosamenti parlando, tutti gli uomini, salvo gli agricoltori e quelli che ci proccurano il vestito di prima necessita".

${ }^{91}$ Cf. LEOPARDI, Giacomo. Discorso sopra lo stato presente dei costumi degl'italiani, p. 52. 
seja, daquela estreita ${ }^{92}$. Fora dessa sociedade reduzida, a "ambição" não "tem nenhum lugar no homem, e o amor próprio natural não tomaria jamais esse aspecto, que até parece totalmente seu e essencial e totalmente imediato. A ambição pode ter várias formas e vários fins" ${ }^{93}$.

Leopardi reconhece que, com a queda da civilização clássica, não resta senão conduzir a ambição para os fins sociais ou, como diz o Discorso, para as "várias formas e vários fins [varie forme e vari fini] da ambição. Nesse momento de sua exposição, Leopardi remonta, a fim de destacar as mudanças ocorridas na Modernidade, à idade clássica em que "era desejo de glória, paixão que foi muito comum [era desiderio di gloria, passione che fu comuníssima] ${ }^{94}$. Daí ele acrescentar:

Mas agora essa é coisa demasiado grande, demasiado nobre, demasiado forte e viva para que ela possa ter lugar na pequenez das ideias e das paixões modernas, restritas e reduzidas a estreitíssimos termos e a baixíssimos graus da razão geométrica e do estado político da sociedade; para que ela possa aparecer com o estatuto de indiferença e mortificação que decorre universalmente na vida civil das ditas causas; e a glória é uma ilusão demasiado esplêndida e um nome demasiado alto para que possa durar após a destruição das ilusões, e o conhecimento da verdade e realidade das coisas, e do peso e valor delas ${ }^{95}$.

Ao enfrentar os efeitos do processo de modernização sobre as antigas ideias da civilização anterior, Leopardi reafirma a incompatibilidade das antigas ilusões com a nova ordem do presente, pois o

amor da glória é incompatível com a natureza dos tempos presentes, é algo obsoleto como os hábitos e as vozes

\footnotetext{
${ }^{92}$ Cf. LEOPARDI, Giacomo. Discorso sopra lo stato presente dei costumi degl'italiani, p. 52.

${ }^{93}$ Cf. LEOPARDI, Giacomo. Discorso sopra lo stato presente dei costumi degl'italiani, p. 52: ha luogo alcuno nell'uomo, e l'amor próprio naturale non prenderebbe mai questo aspetto, che pur sembra totalmente suo próprio ed essenziale e sommamente immediato. L'ambizione può aver varie forme e vari fini".

${ }^{94}$ Cf. LEOPARDI, Giacomo. Discorso sopra lo stato presente dei costumi degl'italiani, p.52.

95 Ibidem: "Ma ora questa è cosa troppo grande, troppo nobile, troppo forte e viva perch'ella possa aver luogo nella piccolezza delle idee e delle passioni moderne, ristrette e ridotte in angustissimi termini e in bassissimo grado dalla ragione geométrica e dallo stato político delle società; perch'ella possa compatire collo stato di freddezza e mortificazione che risulta universalmente nella vita civile dalle dette cause; e la gloria è un'illusione troppo splendida e un nome troppo alto perché possa durare dopo la strage delle illusioni, e la conoscenza della verità e realtà delle cose, e del loro peso e valore".
} 
antiquadas, não subsiste mais, ou é tão raro, e onde subsiste é tão frágil e ineficaz que não pode ser princípio de grandes bens para a sociedade e muito menos servi-la de vínculo, como era em grande parte uma vez ${ }^{96}$.

Nos tempos presentes [tempi present], conforme o Discorso, e nas società strette, a ambição produz um sentimento de caráter moderno e, por sua natureza, "posterior às grandes ilusões da Antiguidade" [posteriore alle grande illusioni dell'antichità $]^{97}$. Trata-se do sentimento de honra, por sua vez uma ilusão porque

consiste em estima que os indivíduos fazem da opinião dos outros com relação a eles, opinião que rigorosamente falando, é algo de pouco valor, mas [...] é uma ilusão tão pouco alta e viva e luminosa que facilmente esconde também aos olhos exercitados pelo conhecimento do verdadeiro, a sua vacuidade, e por aparecer com o estado presente e com a destruição de quase todas as outras ilusões, a qual ela repugna senão mediocremente, considerada a sua natureza, [...] fria e reposta. Essa ilusão, porém, é muito poderosa nas nações e nas classes que fazem uso daquela íntima sociedade da qual apenas ela pode nascer ${ }^{98}$.

Leopardi destaca o sentido prático dessa "ilusão" moderna e seu valor nas "sociedades estreitas" (società strette). Se tal "ilusão" é contestada por filósofos no domínio teórico, o mesmo não ocorre no universo imediato das relações na vida civil. No seu entender, na França, muitos foram os filósofos que combateram, como "conhecedores íntimos do verdadeiro em toda a sua extensão" [conoscitori intimi del vero in tutta la sua estensione] e que sentiram igualmente "a vacuidade e nulidade das coisas e dos homens" [la vanità e nullità delle cose e degli uomini $]^{99}$, a opinião pública. Contudo, "no fato e na

${ }^{96}$ Ibidem: 'L'amore della gloria è incompatibile colla natura de' tempi presenti, è cosa obsoleta come le usanze e le voci antiquate, non sussiste più, o è cosi raro, e dove anche sussiste è cosi debole e inefficace che non può esser princìpio di grandi Beni alla società e molto meno servirle di vincolo, quale egli era in gran parte una volta".

${ }^{97}$ Cf. LEOPARDI, Giacomo. Discorso sopra lo stato presente dei costumi degl'italiani, p. 52.

${ }^{98}$ Ibidem, pp. 52-53: "consiste nella stima che gl'individui fanno della opinione altrui verso loro, opinione che rigorosamente parlando, è cosa di niun conto; ma egli è um illusione tanto poco alta e viva e luminosa che facilmente nasconde anche agli occhi esercitati dall cognizione del vero, la sua vanità, e può compatire collo stato presente e colla distruzione di quase tutte l'altre illusioni, alla quale Ella non ripugna se non mediocremente, atteso la sua natura, [...] fredda e rimessa. Questa illusione però è potentissima nelle nazioni e nelle classi che hanno l'uso di quella intima società da cui solo ella può nascere".

${ }^{99}$ Cf. LEOPARDI, Giacomo. Discorso sopra lo stato presente dei costumi degl'italiani, p. 53. 
vida" [nel fatto e nella vita] ${ }^{100}$, eles jamais mostraram "não só de não se preocupar realmente com a opinião pública, mas nem sequer de não pô-la, quanto ao êxito e quanto ao fundo do seu ânimo, no alto de seus pensamentos e dos seus fins, e de não dirigir a ela o que resta das suas ações e das suas omissões"101.

Leopardi enfatiza que nessas sociedades restritas, a "opinião pública" quase é suficiente - conforme as circunstâncias sociais - para suprir os "princípios morais" [principi morali], igualmente perdidos, sobretudo, nas classes não trabalhadoras. Ademais, a "opinião pública", por causa da perda dos antigos vínculos, passa também a suprir "os outros vínculos da sociedade, os outros freios do mal e estímulos do bem, no lugar dos quais resta, pode-se dizer, isso apenas, [sendo] mesmo suficiente para servir à sociedade como liame" ${ }^{102}$.

\subsection{Modernização e vínculos civis: a especificidade italiana}

Para Leopardi, a ausência de uma sociedade restrita causou impactos devastadores na Itália, por a vida não possuir nem mesmo "aparência" [apparenza] para ser considerada como algo importante. A falta de "centro" [centro] e, consequentemente, de um teatro nacional e de uma literatura nacional moderna, responsáveis em outras nações pela conformidade de opiniões, de gostos, costumes, maneiras e caráter individuais, além de outras razões $^{103}$, determinou também a inexistência de um "público italiano" [pubblico

\footnotetext{
100 Ibidem.

${ }^{101}$ Ibidem: "non solo di non curar veramente l'opinione pubblica, ma neppure di non metterla quanto all'effetto e quanto al fondo del suo animo, nella cima de' suoi pensieri e de' suoi fini, e di non volgere a quella il più delle sue azioni e delle sue omissioni".

102 Ibidem, p. 54: "gli altri vincoli della società, gli altri freni del male e stimoli del bene, in luogo de' quali resta si può dire esso solo, ed è pur sufficiente a servire alla società di legame".

103 Leopardi estabelece uma estreita relação entre a ausência de língua e literatura propriamente modernas, na Itália, com a "nulidade" [nullità] do poder político e militar italianos, em razão, quer do aguçamento das diversas guerras e divisões internas quer das invasões e influências político-culturais estrangeiras, verificadas a partir do século XVII: algo que culminou, para os italianos, na perda de uma identidade cultural em termos de nação. Os italianos não possuem língua moderna própria, nem literatura e filosofia modernas porque "não são mais uma nação". Sem "política e sem milícia, não influem mais, nem sobre a sorte dos outros, nem sobre a sua própria, não governam nem se governam, e a existência deles ou o seu modo de ser é indiferente ao resto da Europa" (Cf. LEOPARDI, Giacomo. Zibaldone di pensieri, pp. 760762). Mario Andrea Rigoni destaca também a importância da noção de nação no interior do
} 
italiano]. Por causa dos modos serem tão diversos quanto o número de cidades e de províncias, não há, portanto, um "bom tom" [buon tuono] determinado e nem "conveniências de sociedade" [bienséances], pois cada indivíduo segue o próprio arbítrio e faz o próprio tom [tuono]. Isso explicaria, em parte, o desprezo dos italianos pela opinião pública e o fato de eles não possuírem verdadeiramente "costumes" [costumi], mas, sobretudo, "usos" [usanze] ou "hábitos" [abitudini] ${ }^{104}$. Ele narra aqui os efeitos que a ausência de uma sociedade restrita causou na vida dos italianos:

Não falo da total falta de indústria, de toda espécie de atividade, e aquela [falta] de carreiras políticas e militares, aquela de qualquer outro instituto de vida e de profissão pela qual o homem mire a um fim, e com a expectativa, com os intentos, com as esperanças do porvir, eleve o valor da existência, a qual sempre que falta de perspectiva de um futuro melhor, sempre que restrita apenas ao presente, não pode deixar de parecer coisa

pensamento leopardiano quando escreve: "A referência explícita e recorrente à individualidade italiana na obra de Leopardi se explica com o relevo decisivo que assume aos seus olhos o tema do espírito nacional, 'sem o qual - ele escreve no Zibaldone di pensieri, em 24 de março de 1821 - jamais existiu grandeza neste mundo, não só grandeza nacional, mas nem sequer grandeza individual' [...]. A 'nação' ou a 'pátria' (os dois termos são quase sinônimos em Leopardi) é o princípio de vida e de afirmação dos povos, como mostra a sucessão na hegemonia do mundo, inicialmente, da Ásia, posteriormente, do Egito, da Grécia, em seguida, da Itália romana e, em tempos recentes, da França revolucionária e napoleônica: por outro lado, à falta de nação e de espírito nacional pode se restabelecer, definitivamente, a decadência que a Itália conheceu, a partir, pelo menos, do século XVI, em cada aspecto da sua vida: político, militar, social, moral, cultural" (Cf. RIGONI, Mario Andrea. "Leopardi e i costumi degli italiani". In: LEOPARDI, Giacomo. Discorso sopra lo stato presente dei costumi degl'italiani, p.6.). Sobre o debate no século XVIII em torno à noção de um principium iundividuationis dos povos meridionais e a especificidade da abordagem leopardiana, quanto ao conceito de "meridionalidade no tempo" [meridionalità nel tempo] e de suas implicações concernentes à ação humana, nas quais se entrelaçam "geografia e história, natureza e cultura, antigo e moderno" numa dialeticidade infinita de relações, ver aqui PLACANICA, Augusto. Leopardi e il Mezzogiorno del mondo. Napoli: Avagliano, 1998, pp. 73-131.

${ }^{104}$ Ezio Raimondi, em seu escrito Leterattura e identità nazionale, busca esclarecer o caráter distintivo dos conceitos leopardianos de "costumi", "usanze" ou "abitudini". Diz o autor: "Os 'costumes' são os valores que vêm do passado, aceitos por cada um de nós com um ato de responsabilidade pessoal. Os costumes se transmitem e cada um escolhe, aliás, decide assumi-los sobre si, tornando-os parte integrante da identidade individual. Os usos e os hábitos se recebem passivamente: não exigem uma resposta, mas apenas uma aceitação mais ou menos mecânica. $O$ costume nasce, afinal, também de uma responsabilidade que o cidadão se assume, enquanto o uso e o hábito não comportam o confronto e o 'medir-se com o outro'. Por vezes, quando não ocorrem os costumes, se encontram apenas usos, entendidos como realidade provinciana, como âmbitos mais restritos, quase locais. Disso e, ao mesmo tempo, do desenvolvimento do pensamento radical moderno, depende o 'enfraquecimento dos princípios morais', os quais se fundam sobre a persuasão: tais 'princípios' valem, de fato, apenas se o indivíduo os considera partes essenciais de si" (Cf. RAIMONDI, Ezio. "Un poeta e la società: Giacomo Leopardi, Discorso sopra lo stato presente dei costumi degl'italiani". In: Leterattura e identità nazionale. Milano: Mondadori, 1998, pp. 60-61.). 
muito vil e sem momento, porque no presente, isto é, naquele que está submetido aos olhos, não têm lugar as ilusões, fora das quais não existe a importância da vida. Ora, a vida dos italianos é precisamente tal, sem perspectiva de melhor sorte futura, sem ocupação, sem finalidade e restrita apenas ao presente. Mas deixando isso de lado e nos restringindo unicamente à falta de sociedade, certamente que é um dos maiores e principais meios que restam hoje aos homens para não se aperceber demasiado da nulidade das coisas deles ou para não a sentir, embora a conheçam, para não serem na prática persuadidos pela total frivolidade de quaisquer que sejam as suas ocupações e pela total indignidade da vida, para ser com fadigas e com solicitudes cultivada, estudada e exercitada, um, digo, dos principais meios e talvez o principal absolutamente, é a sociedade ${ }^{105}$.

No entender de Leopardi, o pouco valor que a vida tem para os italianos se observa também pela raillerie e o persifflage presentes na pouca "conversação" [conversazione] estabelecida entre eles. Ele diz serem

105 Ibidem, p. 59: "Lascio la totale mancanza d'industria, e d'ogni sorta di attività, quella di carriere politiche e militari, quella d'ogni altro istituto di vita e di professione per cui l'uomo miri a uno scopo, e coll'aspettativa, coi disegni, colle speranze dell'avvenire, rilevi il pregio dell'esistenza, la quale sempre che manca di prospettiva d'un futuro migliore, sempre ch'è sottoposto agli occhi, non hanno luogo le illusioni, fuor delle quali non esiste l'importanza della vita. Or la vita degl'italiani è appunto tale, senza prospettiva di miglior sorte futura, senza occupazione, senza scopo, e ristretta al solo presente. Ma lasciando questo e ristringendoci alla sola mancanza di società, certo è che uno de' grandissimi e principali mezzi che restano oggi agli uomini per non avvedersi affatto della nullità delle cose loro o per non sentirla, benché conoscendola, per non essere nella pratica persuasi della total frivolezza delle loro occupazioni qualunque e della totale indegnità della vita ad esser con fatiche e con sollecitudini coltivata, studiata e esercitata, uno, dico, de' principali mezzi e forse il principale assolutamente, è la società". Segundo Binni, a falta de referências mais precisas sobre a situação da sociedade italiana nas Operette morali é compensada pela atenção dada por Leopardi aos fatos contemporâneos de tal sociedade em seu Discorso de 1824, pois, nesse escrito, está fundamentada "a constatação de que a condição de menor idade da Itália ante as outras nações europeias é devida, sobretudo, à falta de uma opinião pública e de uma verdadeira 'sociedade', à perda dos valores da 'natureza' e a não aquisição daqueles [valores] da 'civilização' (por isso esses [italianos] não têm 'costumes', mas 'hábitos' e vivem uma vida mesquinha, dominada pelo 'cinismo', pelo 'egoísmo', pela 'misantropia') que vem promovida e difundida 'o mais que se possa', 'como remédio de si mesma por um lado e, por outro, do que resta da corrupção extrema e barbárie dos baixos tempos [Idade média]'. Por isso, a mesma batalha pela verdade das Operette morali, na medida em que desenvolve e define, com a força conjunta da análise intelectual e da evidência poética, o processo mais profundo das posições leopardianas - fruto de uma inteira experiência que se faz, na diagnose mais completa, agressiva e polêmica - não faltaria, por meio do seu liame com o Discorso, de um possível nexo com a mesma situação italiana e a busca (por enquanto mais contraditória e confusa) de uma fundamentação completa de civilização e de sociedade, renovadas pela coragem moral da verdade e pela diagnose sem preconceitos da situação humana" (Cf. BINNI, Walter. La protesta di Leopardi. Milano: Sansoni, 2000, p. 94). 
incalculáveis, para o convívio social, os prejuízos exercidos por este tipo de má conversação, pois defende o princípio de que o homem seja um "animal imitativo e de exemplo" [animale imitativo e d'esempio] ${ }^{106}$. Para se defender da guerra recíproca dos modos de tratamento e para não ser oprimido, Leopardi sustenta ser preciso aprender também a "ofender" [offendere] ${ }^{107}$. Isso não ocorre, no entanto, sem antes se contrair um hábito de desestima, desprezo e grande indiferença por si mesmo, "porque não há coisa mais nociva neste modo de conversar que ser delicado e sensível a respeito de si mesmo"108.

Leopardi defende, entretanto, ser o atual estado de indiferença e cinismo social dos italianos o mais "razoável" [ragionevole] e "natural" [naturale] à condição de desengano a que se reduziram, embora seja muito danoso para os costumes. Daí ele dizer que os italianos são na prática, e em parte no intelecto, mais filósofos que qualquer filósofo estrangeiro, por estarem "domesticados" [addomesticati] ${ }^{109}$, por conviverem e se identificarem com aquele conhecimento que representa a "soma de toda a filosofia" [somma di tutta la filosofia] ${ }^{110}$, a saber, a da vacuidade da vida. Mais do que conhecimento, o vazio é antes sentimento, opinião amplamente compartilhada entre os italianos.

Conhecidas bem a fundo e continuamente sentindo a vacuidade e a miséria da vida e a má natureza dos homens, não querendo ou não sabendo ou não havendo coragem, ou mesmo com coragem, não tendo força para disso se desesperar, e de chegar aos extremos contra a necessidade e contra si mesmo, e contra os outros, que seriam sempre igualmente incorrigíveis; querendo ou devendo mesmo viver e resignar-se e ceder à natureza das coisas, continuar numa vida que se despreza, conviver e conversar com homens que se conhecem por tristes e para nada - o mais sábio partido é aquele de rir indistintamente e habitualmente de tudo e de todos, começando por si mesmo ${ }^{111}$.

\footnotetext{
${ }^{106}$ Cf. LEOPARDI, Giacomo. Discorso sopra lo stato presente dei costumi degl'italiani, p. 59.

${ }^{107}$ Cf. LEOPARDI, Giacomo. Discorso sopra lo stato presente dei costumi degl'italiani, p. 67.

108 Ibidem, p. 68: "perché non v'è cosa più nociva in questo modo di conversare che l'esser dilicato e sensibile sul proprio conto".

${ }^{109}$ Cf. LEOPARDI, Giacomo. Discorso sopra lo stato presente dei costumi degl'italiani, p. 64. ${ }^{110}$ Ibidem.

111 Ibidem, p. 65: "Conosciuta ben a fondo e continuamente sentendo la vanità e la miseria della vita e la mala natura degli uomini, non volendo o non sapendo o nona vendo coraggio, o anche col coraggio, nona avendo forza di disperarsene, e di venire agli estremi contro la necessità e
} 
Leopardi sabe que a indiferença e o cinismo são prejudiciais aos liames sociais, porque não estimulam, na convivência diária, a estima, o respeito, nem o sentimento de honra: tão importantes e necessários ao convívio moderno, por serem os únicos possíveis após o "aniquilamento das ilusões" [strage delle ilusioni] antigas. Ele sabe também que esses "incômodos" [incomodi] se apresentam, em maior ou menor grau, em todas as avançadas nações europeias, pois é reconhecido por todos como algo "característico deste século" [caratteristico di questo secolo] o gênero de amor próprio que se chama "egoísmo" [egoísmo ${ }^{112}$. Tais "inconvenientes" [inconvenienti], porém, foram mais graves na Itália, porque em sentido moral ela se encontra "desprovida" [sprovveduta] de fundamentos mais que qualquer outra nação europeia ${ }^{113}$.

Se, de um lado, a desvantagem da Itália se apresenta em relação às nações mais cultas ou instruídas, mais sociais, ativas e vivas (Alemanha, Inglaterra e França), por elas terem reelaborado os seus princípios morais mediante as sociedades restritas, de outro, igual desvantagem se revela ante as nações menos cultas, instruídas e menos sociais (Rússia, Polônia, Portugal e Espanha), por conservarem grande parte dos "preconceitos dos séculos passados" [pregiudizi de' passati secoli ${ }^{114}$. Tais preconceitos servem ainda de "garantia" [garanzia] para a moral na Espanha, embora ela esteja privada daquela que é produzida pela sociedade, a saber, o sentimento de honra. Leopardi admite ser a Espanha uma nação com princípios morais mais firmes que a Itália, ainda que o fundamento de tal moral consista apenas nos preconceitos e na "ignorância" das revelações das luzes modernas.

Para Leopardi, no entanto, quer a Espanha quer as nações que the assemelham, estão submetidas a "infinitos inconvenientes" [infiniti

contro se stesso, e contro gli altri che sarebbero sempre ugualmente incorreggibili; volendo o dovendo pur vivere e rassegnarsi e cedere alla natura delle cose, continuare in una vita che si disprezza, convivere e conversar con uomini che si conoscono per tristi e da nulla; il più savio partito è quello di ridere indistintamente e abitualmente d'ogni cosa e d'ognuno, incominciando da se medesimo".

112 Cf. LEOPARDI, Giacomo. Discorso sopra lo stato presente dei costumi degl'italiani, pp. 7071.

${ }^{113}$ Cf. LEOPARDI, Giacomo. Discorso sopra lo stato presente dei costumi degl'italiani, p. 71.

${ }^{114}$ Cf. LEOPARDI, Giacomo. Discorso sopra lo stato presente dei costumi degl'italiani, p. 71. 
inconvenienti] e a uma condição "não invejável" [non invidiabile], por viverem em um estado distanciado da "cultura" [coltura] e da "natureza" [natura], ou seja, em tempos "muito corruptos" [corrotissimi]" ${ }^{115}$. A distinção da nação espanhola não decorre, portanto, por estar próxima à natureza, como 0 defendia Chateaubriand $^{116}$, e nem aos tempos antigos, mas por sozinha ter-se conservado da "barbárie da Idade média" [barbarie dell'età media] ${ }^{117}$ mais que todas as outras nações juntas. Daí o estado do povo espanhol, não ser nem civil e nem natural, mas "simplesmente bárbaro" [semplicemente barbaro]. 0 autor não compartilha da crença aceita pela maioria dos filósofos de sua época, ou seja, a da identificação entre Idade antiga e Idade média:

é um modo de ver demasiado falso aquele de considerar a civilização moderna como libertadora da Europa do estado antigo. Este falso conceito prejudica de maneira geral o julgamento e o verdadeiro modo de pensar sobre a história e as vicissitudes do gênero humano e das nações, e é um erro ou uma falta de atenção muito substancial, que turva e falsifica toda a ideia que um filósofo pode conceber mais amplamente sobre a dita história e sobre os progressos ou andamentos do espírito humano. O ressurgimento foi da barbárie dos baixos tempos, não do estado antigo; a civilização, as ciências, as artes, as luzes, renascendo, avançando e propagandose não nos libertaram do antigo, mas, aliás, da total e horrível corrupção do antigo. Em suma, a civilização não nasce no século XV na Europa, mas renasce ${ }^{118}$.

Para Leopardi, a civilização moderna, sua filosofia e seus progressos, merecem louvor apenas por libertarem a civilização da "barbárie dos baixos

\footnotetext{
${ }^{115}$ Cf. LEOPARDI, Giacomo. Discorso sopra lo stato presente dei costumi degl'italiani, p. 73.

${ }^{116}$ Cf. LEOPARDI, Giacomo. Discorso sopra lo stato presente dei costumi degl'italiani, p. 71.

117 Cf. LEOPARDI, Giacomo. Discorso sopra lo stato presente dei costumi degl'italiani, p. 73.

118 Ibidem, pp. 72-73: "Ė un falsissimo modo di vedere quello di considerar la civiltà moderna come liberatrice dell'Europa dallo stato antico. Questo falso concetto guasta generalissimamente il giudizio e il vero modo di pensare sulla storia e le vicende del genere umano e delle nazioni, ed è un errore o una svista sostanzialissima che turba e falsifica tutta l'idea che un filosofo può concepire in grande sulla detta storia e sui progressi o andamenti dello spirito umano. II risorgimento è stato dalla barbarie de' tempi bassi non dallo stato ântico; la civiltà, le scienze, le arti, i lumi, rinascendo, avanzando e propagandosi non ci hanno Liberato dall'antico, ma anzi dalla totale e orribile corruzione dell'antico. In somma la civiltà non nacque nel quattrocento in Europa, ma rinacque". Sobre a problemática relativa às mudanças na Europa e contexto da problemática italiana, ver PLACANICA, Augusto. Leopardi. II Mezzogiorno in Idea e l'Italia. In: (org.). Michele Dell'Aquila. Ripensare Leopardi. Fasano (BrItalia): Schena Editore, 1999, pp. 48-91; BIRAL, Bruno. La "posizione storica" di Leopardi. In: La posizione storica di Giacomo Leopardi. Torino: Einaudi, 1997, pp. 97-134.
} 
tempos" [barbarie de' tempi bassi], sendo necessário, entretanto, "duvidar" [dubitare] do benefício de tais progressos para os homens. Ele compara as diversas épocas da civilização humana mediante a capacidade dos costumes e das opiniões para favorecer, conduzir e gerar a grandeza do espírito e da ação, enfim, segundo o critério da "felicidade" [felicita], "virtude" [virtù], "valor" [valore], "energia e atividade" [energia ed attività] dos homens, quer sejam considerados separadamente como indivíduos quer socialmente como um "corpo" [corpo]. Dessa comparação as sociedades antigas surgem como paradigma a ser seguido pelas civilizações modernas.

\subsection{Fragilidade dos vínculos civis modernos: frivolidade nos costumes na società stretta}

Leopardi reconhece, certamente, os novos vínculos constituídos pelas nações modernas, ante a dissolução universal dos princípios sociais de outrora, ou seja, aqueles que fundamentavam a moral na civilização clássica. Contudo, ele sabia da fragilidade dos novos liames das "sociedades estreitas", não obstante ser a única forma possível na Modernidade de se conservar a vida civil. Era uma busca preencher o vazio decorrente do desaparecimento das ilusões com novos princípios, e novos costumes adequados à nova ordem das coisas $^{119}$.

Se, nessas sociedades, a "opinião pública" deve sugerir os "princípios morais", perdidos após o processo de modernização, ela passa igualmente a substituir os antigos liames da sociedade. Contudo, Leopardi identifica, mesmo que a via adotada pelas "sociedades estreitas" vise a conservação, que os "homens polidos" [uomini polit] dessas sociedades "se abstêm de fazer o mal e fazem o bem, não movidos pelo dever, mas pela honra. [...] As ilusões sociais cessam na solidão, a honra desaparece, porque subraído aos olhos aquilo que Ihe dava [à honra] aparência e uma espécie de realidade, se vê a irracionalidade, a vacuidade e a frivolidade" ${ }^{\prime 20}$.

${ }^{119}$ Cf. LEOPARDI, Giacomo. Discorso sopra lo stato presente dei costumi degl'italiani, pp. 5071.

${ }^{120}$ Cf. LEOPARDI, Giacomo. Discorso sopra lo stato presente dei costumi degl'italiani, p. 55: "Gli uomini politi delle dette nazioni si astengono da fare il male e fanno il bene, non mossi dal dovere, ma dall'onore. [...] Le illusioni sociali cessano nella solitudine, l'onore sparisce, perché 
Com base apenas na "opinião pública" se estabelecem nessas "sociedades" o trato civil. Os "homens polidos" [uomini politi], conforme escreve Leopardi, pertencentes àquelas nações nas quais essa substituição tornou-se possível, ou seja, de certas ilusões antigas capazes de vínculos, no presente moderno eles "se envergonham de fazer o mal como aparecer em uma conversação com uma mancha na veste ou com um vestuário gasto ou rasgado" ${ }^{21}$. Por conseguinte, esses "homens" dirigem-se "para fazer o bem pela mesma causa, e com não menor empenho e sentimento, que para examinar exatamente e realizar as modas, buscando brilhar com os vestuários, com os enxovais, com as mobílias, com as pompas"122.

Leopardi critica nessas sociedades a fragilidade e frivolidades dos princípios que orientam os seus costumes. Daí dizer, reportando-se a esses "homens", que "o luxo e a virtude ou a justiça têm entre eles o mesmo princípio, não apenas falando à distância [...], mas [...] de imediato e em particular" ${ }^{123}$. Ele questiona, portanto, a redução dos antigos ideais, que outrora fundamentavam a moral, à frivolidade no estado presente. Por conseguinte, na nova época, o critério de uma "boa ação" [buona azione ${ }^{124}$ não ultrapassa aquele de se portar um "belo vestuário" [bell'abito] ${ }^{125}$. Para Leopardi é estranho o reportar-se à "probidade" [probità] pela única razão de se ter o cuidado de adquirir e conservar a "bela maneira" [bella maniera ${ }^{126}$.

tolto dagli occhi quello che le dava apparenza e una specie di realtà, se ne vede l'irragionevolezza, la vanità e la frivolezza".

${ }^{121}$ Cf. LEOPARDI, Giacomo. Discorso sopra lo stato presente dei costumi degl'italiani, p. 54: "si vergognano di fare il male come di comparire in una conversazione con una macchia sul vestito o con un panno logoro o lacero".

122 Ibidem: "a fare il bene per la stessa causa e con niente maggiore impulso e sentimento che a studiar esattamente ed eseguir le mode, a cercar di brillare cogli abbigliamenti, cogli equipaggi, coi mobili, cogli apparati”.

123 Ibidem: "il lusso e la virtù o la giustizia hanno tra loro lo stesso principio, [...] ma [...] immediatamente e particolarmente". Sobre a problemática da vida civil nas nações européias e a busca de outros princípios para o trato civil, ver comentários de Placanica: PLACANICA, Augusto. Leopardi, o della modernità, in: LEOPARDI, Giacomo. Dei costumi deglitaliani. Venezia: Marsilio, 1992, pp. 9-112. Ver aqui ainda a leitura de Dondero sobre o Discorso: DONDERO, Marco. Leopardi e gli italiani. Ricerche sul "Discorso sopra lo stato presente dei costumi degl'Italiani. Napoli: Liguori, 2000.

${ }^{124}$ Cf. LEOPARDI, Giacomo. Discorso sopra lo stato presente dei costumi degl'italiani, p. 54.

${ }^{125}$ Cf. LEOPARDI, Giacomo. Discorso sopra lo stato presente dei costumi degl'italiani, p. 54.

${ }^{126}$ Ibidem: "lo stato delle opinioni e delle nazioni quanto alla morale è ridotto in questa precisa miséria che il buon tuono". 
Aqui se apresenta a recusa leopardiana à banalização dos princípios morais, à fragilização dos novos critérios e à frivolidade no trato entre os "homens polidos". Ele critica a forma dos comportamentos na vida civil, pois se priorizam a "dissimulação" [dissimulazione] e a "aparência" [apparenza]: "o estado das opiniões e das nações, quanto à moral, está reduzido a essa precisa miséria que o bom"127. Este último, por sua vez, "é não só o mais forte, mas o único fundamento que resta para os bons costumes" [è, non solo il più forte, ma l'unico fondamento che resti a' buoni costumi ${ }^{128}$. Ademais, conforme Leopardi, "os bons costumes não são exercitados [...], geralmente falando, e das classes civis, pelas razões pelas quais se exercita o bom tom" ${ }^{129}$.

Em razão da necessidade de se estabelecer novos vínculos, após a strage delle illusioni, Leopardi sabe que, nessas sociedades, o "bom tom" é aquilo que se apresenta como "realidade", ou aparência de realidade. Ele sustenta que "onde o bom tom da sociedade não existe ou não se cuida, ali a moral perde todo o fundamento e a sociedade todo vínculo, fora o da força, a qual não poderá jamais, nem produzir os bons costumes nem banir ou manter distantes os maus" 130 .

Nessas nações modernas, a sociedade, Leopadi escreve, ao produzir o "bom tom" [buon tuono] ${ }^{131}$ produz "a maior, ou melhor, a única garantia dos costumes tanto públicos quanto privados, que se possa agora ter e, portanto, é causa imediata da conservação de si mesma"132. Leopardi sabe que o presente se fundamenta em uma moralidade muito diversa. Ao falar de "inutilidade da virtude" [inutilità della virtù] e a "utilidade do vício" [utilità del vizio], Leopardi sabe de se encontrar em outra civilização, pois são dependentes da constituição política das presentes repúblicas [dipendente dalla política

\footnotetext{
${ }^{127}$ Cf. LEOPARDI, Giacomo. Discorso sopra lo stato presente dei costumi degl'italiani, p. 54.

${ }^{128}$ Cf. LEOPARDI, Giacomo. Discorso sopra lo stato presente dei costumi degl'italiani, p. 54.

129 Ibidem: "i buoni costumi non sono esercitati per altro, generalmente parlando e delle classi civili, che per le ragioni per cui si esercita il buono tuono".

${ }^{130}$ Ibidem: "dove il buon tuono della società non v'è o non si cura, quivi la morale manca d'ogni fondamento e la società d'ogni vincolo, fuor della forza, la quale non potrà mai né produrre i buini costumi né bandire o tener lontani i cattivi".

${ }^{131}$ Cf. LEOPARDI, Giacomo. Discorso sopra lo stato presente dei costumi degl'italiani, p. 55.

132 Ibidem: "Ia maggiore anzi única garanzia de' costumi si pubblici che privati, che si possa ora avere, e quindi è causa immediata della conservazione di se medesima".
} 
costituzione delle presente repubbliche] ${ }^{133}$. Contudo, esses estados se apresentam, não obstante o caráter artificioso dos vínculos, após a razão levar à ruína as antigas ilusões, como aquele possível no presente.

Quando se considera, porém, as suas reflexões desenvolvidas ao longo do Zibaldone di pensieri [1817-1832] sobre as "sociedades estreitas", tornamse mais claras ainda as suas "suspeitas" e a sua crítica a esse gênero de sociedade, pois Leopardi concebe, de início, que "uma sociedade [...] perfeita entre os homens, ou melhor, uma sociedade verdadeira, é impossível" ${ }^{134}$. Mais adiante, ele indaga: "Ora como pode ser impossível, se a natureza nos a [...] destinou, e se o homem fora de uma tal sociedade não pudesse conseguir a sua perfeição e felicidade natural?" ${ }^{135}$ Aquela "sociedade" [società], como define Leopardi, destinada pela natureza aos animais tão inferiores aos homens, foi, desde sempre "perfeita no seu gênero, embora não tivessem tido, e não tenham, nem legisladores, nem filósofos, nem experiências de outras formas de sociedade"136. Se comparada, não a seu gênero, mas à ideia de sociedade cumpridora do bem da "multidão" [moltitudine] e só acidentalmente cause prejuízos, tal "sociedade" é perfeita.

Tendo como base essas formulações, Leopardi retorna às suas indagações: "não devemos, portanto, deduzir do sobredito, sejam razões sejam experiências de tantos e tantos séculos, que o gênero humano por natureza, ou não está destinado a nenhuma sociedade entre si, ou (como é verdade) está destinado a um gênero, ou melhor, a um grau de sociedade diferente, de fato, de todos aqueles que nesse [grau] ele teve lugar desde os primeiríssimos

${ }^{133}$ Cf. LEOPARDI, Giacomo. Discorso sopra lo stato presente dei costumi deglitaliani, p. 50. Sobre uma releitura do Discorso ver NEGRI, Antimo. Rileggendo il leopardiano "Discorso sopra lo estato presente dei costumi degl'italiani, in: (org.). CACCIATORE, Giuseppe. Le operette morali di Giacomo Leopardi. Assisi: Cittadella, 2000, pp. 175-192.

134 LEOPARDI, Giacomo. Zibaldone di pensieri, fragmento 3776, 25.10.1823, in: Tutte le poesie, tutte le prose e lo Zibaldone, p. 2193: "una società [...] perfetta fra gli uomini, anzi pure una società vera è impossibile".

135 LEOPARDI, Giacomo. Zibaldone di pensieri, fragmento 3776-3777, 25.10.1823, in: Tutte le poesie, tutte le prose e lo Zibaldone, p. 2193: "Or come può star che sia impossibile, se la natura ce l'avesse [...] destinata, e se l'uomo fuor di una tal società non potesse conseguire la sua perfezione e felicità naturale?".

${ }^{136}$ LEOPARDI, Giacomo. Zibaldone di pensieri, fragmento 3777, 25.10.1823, in: Tutte le poesie, tutte le prose e lo Zibaldone, p. 2193: "perfetta nel suo genere, bench'essi non abbiano avuti e non abbiano nè legislatori, nè filosofi, nè esperienze d'altre forme di società". 
inícios do seu [...] desbaste até os dias de hoje?" 137 Para Leopardi, esse "grau de sociedade diferente" teria um grau muito escarso de "comunhão" [comunione] entre os indivíduos, no qual se exigiria, à medida do desenvolvimento, que cada indivíduo conspirasse pelo "bem comum" [comum bene] dos indivíduos nela partícipe e, nenhum, a não ser por acaso a prejudicasse. Disso resultaria uma espécie de "sociedade perfeita" [società perfetta] para os homens, conforme a ideia e as condições essenciais da sociedade absolutamente considerada ${ }^{138}$.

Tendo se perdido, hoje, essa espécie de sociedade, nenhuma outra espécie de "sociedade perfeita" [società perfetta] pode jamais, afirma Leopardi, substitui-la durante milhares de anos ${ }^{139}$. Essa espécie de sociedade jamais será substituída, "porque a natureza não se substitui, não mais de uma só perfeição (ou seja, do seu estado natural) pode convir a alguma espécie de seres criados e, por isso, não mais do que uma felicidade" ${ }^{140}$. Quanto a uma "sociedade estreita" [società stretta], Leopardi reconhece que ela produz desigualdade de vários gêneros entre os homens e em torno de inúmeros bens e males. Tal espécie de "sociedade" aguça e põe em movimento "as paixões da inveja, da rivalidade, da competição, do ciúme, consequências necessárias, ou melhor, espécie e nuances do ódio em direção aos outros, natural a toda espécie que ama naturalmente a si mesmo. Ora qual é a coisa mais antisocial do que as paixões?"141

137 LEOPARDI, Giacomo. Zibaldone di pensieri, fragmento 3776, 25.10.1823, in: Tutte le poesie, tutte le prose e lo Zibaldone, p. 2193: "Non dobbiamo dunque dedurre da tutto il sopradetto, sì ragioni, sì esperienze di tanti e tanti secoli, che il genere umano per natura, o non è destinato a società veruna tra se, o (come è vero) è destinato ad un genere, o per meglio dire, ad un grado di società diverso affatto da tutti quelli che in esso lui ebbero luogo dal primissimo principio del suo [...] dirozzamento, fino al dì d'oggi?".

${ }^{138}$ Cf. LEOPARDI, Giacomo. Zibaldone di pensieri, fragmento 3778, 25.10.1823, in: Tutte le poesie, tutte le prose e lo Zibaldone, p. 2193.

${ }^{139}$ Cf. LEOPARDI, Giacomo. Zibaldone di pensieri, fragmento 3778, 25.10.1823, in: Tutte le poesie, tutte le prose e lo Zibaldone, p. 2193.

140 LEOPARDI, Giacomo. Zibaldone di pensieri, fragmento 3778, 25.10.1823, in: Tutte le poesie, tutte le prose e lo Zibaldone, p. 2193: "perchè la natura non si rimpiazza, nè più d'una sola perfezione (cioè del suo naturale stato) può convenire a niuna specie d'esseri creati, e quindi non più d'una felicità".

141 LEOPARDI, Giacomo. Zibaldone di pensieri, fragmento 3778, 25.10.1823, in: Tutte le poesie, tutte le prose e lo Zibaldone, p. 2193: "le passioni dell'invidia, dell'emulazione, della gara, della gelosia, conseguenze necessarie, o piuttosto specie e nuances dell'odio verso gli altri, naturale ad ogni essere che ami naturalmente se stesso. Or qual cosa è più antisociale di queste passioni?". 
Segundo Leopardi, isso não ocorreria em uma "sociedade insuficiente e ampla" [società scarsa e larga], a qual foi destinada pela natureza aos homens, pois limitada à

verdadeira finalidade da sociedade, aquela de se socorrer mutuamente nas necessidades (que na natureza são poucas), e quando muito naquelas necessidades (que são também menos), as quais exigem a conspiração de mais indivíduos, como seria o defender-se dos outros animais inimigos, cujo efeito também os animais menos sociáveis, se reúnem e fazem entre eles uma sociedade momentânea, que dura o quanto o perigo [...]. As ditas paixões [...], não teriam tido lugar, seja pela pouca estreiteza daquela sociedade, seja porque nela e no estado natural do homem, as vantagens naturais de um indivíduo sobre o outro teriam sido poucas, raras e pequenas e os sociais não teriam, de fato, existido. A desigualdade entre os homens que a sociedade torna naturalmente total e de mil gêneros, teria sido quase ineficaz, e limitada a bem poucas coisas ${ }^{142}$.

Leopardi reconhece que essas "paixões" são suscitadas pelas vantagens e desigualdades, inevitavelmente produzidas por uma "sociedade estreita": algo muito raro e muito frágil entre outros animais. Por isso em uma "sociedade insuficiente" [società scarsa], não há lugar a "inveja" [invídia] e a "rivalidade" [emulazione], uma vez que o "comando" entre animais pouco sociáveis decorre da superioridade natural e quase de espécie. Qualquer forma de "proeminência" [preminenza] entre os animais, uma vez que posta pela natureza, é então reconhecida como útil a todos ${ }^{143}$. No caso específico de uma "sociedade estreita", sobretudo, humana,

é necessidade inevitável que tenha lugar as ditas proeminências, como também é necessário que elas

\footnotetext{
142 LEOPARDI, Giacomo. Zibaldone di pensieri, fragmento 3778-3779, 25.10.1823, in: Tutte le poesie, tutte le prose e lo Zibaldone, p. 2193: "vero fine d'ogni società, quello di soccorrersi scambievolmente ne' bisogni (che in natura son pochi), e massime in quei bisogni (che sono anche meno) i quali esiggono la cospirazione di più individui, come sarebbe il difendersi dagli altri animali nemici, al qual effetto anche gli animali meno socievoli, si riuniscono e fanno tra loro una società temporanea, che dura quanto il pericolo [...]. Le dette passioni [...], non avrebbero avuto luogo, sì per la poca strettezza di quella società, sì perchè in essa e nello stato naturale dell'uomo, i vantaggi naturali dell'uno individuo sull'altro sarebbero stati pochi, rari, e piccoli, e i sociali non vi sarebbero stati affatto. La disuguaglianza tra gli uomini che la società rende naturalmente somma e di mille generi, sarebbe stata quasi nulla, e limitata a ben poche cose".

${ }^{143}$ Cf. LEOPARDI, Giacomo. Zibaldone di pensieri, fragmento 3779-3780, 25.10.1823, in: Tutte le poesie, tutte le prose e lo Zibaldone, p. 2193.
} 
ofendam sempre grandemente 0 orgulho natural dos outros indivíduos. Entre essas proeminências é necessidade indispensável que tenha lugar o comando, e este entre os homens não pode ter efeito de superioridade de natureza ou de espécie, mas é necessário que o igual por natureza, seja senhor dos iguais. E o comando e a sujeição entre os homens é incontrastavelmente inevitável que, embora útil com o instituído, na maioria das vezes sejam, ao contrário, muito danoso no resultado para quem obedece e se sujeita, e como tal sejam reconhecidos por eles, disso decorrendo naturalmente uma inveja e um ódio enorme para quem comanda ${ }^{144}$.

É algo inevitável, no entender de Leopardi, que quase sempre o comando e a dominação, conquistados justamente pela força na sua própria origem e constituição, estejam dirigidos para o dano dos subjugados com vantagens apenas para os senhores, ou seja, aqueles comandos conquistados pela força ou por arte, contra a vontade e a intenção dos submissos, denominados tiranias ${ }^{145}$. Daí Leopardi argumentar:

todos e a maior parte dos principados passados $\mathrm{e}$ presentes têm iniciado pela força e pelo artifício, e que todos os tronos da Europa [...] podem, de forma genealógica, reenviar a essas raízes. Em suma, como é algo muito certo que o mundo é o patrimônio da força (seja física, isto é, vigor, seja moral, isto é, engenho e arte etc. que é a mesma coisa), e que é feito para os mais fortes

146

144 LEOPARDI, Giacomo. Zibaldone di pensieri, fragmento 3780, 25.10.1823, in: Tutte le poesie, tutte le prose e lo Zibaldone, pp. 2193-2194: "è d'inevitabile necessità che abbiano luogo tutte le dette preminenze, come altresì è necessario ch'elle sempre offendano grandemente l'orgoglio naturale degli altri individui. E fra esse preminenze è d'indispensabile necessità che v'abbia luogo il comando, e questo fra gli uomini non può esser effetto di superiorità di natura o di specie, ma è necessario che l'uguale per natura, sia signor degli uguali. E il comando e la soggezione fra gli uomini è incontrastabilmente inevitabile che sebbene utili per istituto, il più delle volte sieno anzi dannnosissime in effetto a chi ubbidisce $e$ sottostà, e per tale siano riconosciute da loro, seguendone naturalmente un'invidia e un odio sommo verso chi comanda".

${ }^{145}$ Cf. LEOPARDI, Giacomo. Zibaldone di pensieri, fragmento 3780, 25.10.1823, in: Tutte le poesie, tutte le prose e lo Zibaldone, p. 2194.

${ }^{146}$ LEOPARDI, Giacomo. Zibaldone di pensieri, fragmento 3780-3781, 25.10.1823, in: Tutte le poesie, tutte le prose e lo Zibaldone, p. 2194: "tutti o la più parte dei principati passati e presenti hanno avuto principio dalla forza o dall'artifizio, e che tutti i troni d'Europa [...]si possono, genealigizzando, far risalire a queste radici. Insomma, com'egli è cosa certissima che tutto il mondo è il patrimonio della forza (sia fisica, cioè vigore, sia morale, cioè ingegno, arte ec. ch'è tutt'uno), e ch'egli è fatto per li più forti, ne segue che un una società stretta, inevitabilmente, qualunque forma se gli possa mai dare, i più deboli individui denno essere, furono sono e saranno la preda, la vittima, il retaggio de' più forti". 
Com base nesses argumentos, Leopardi inferi a impossibilidade de que exista "sociedade estreita" com a "finalidade da sociedade" [fine della società], ou seja, o "bem comum" [ben comune], sem o qual a sociedade não tem nenhuma razão de existir. Sempre "cético" em relação à forma da "sociedade estreita" entre os homens, pois contrária à ordem natural, ou seja, a de uma "sociedade ampla" [società larga], na qual "os mais fortes não têm, nem início, [...] oportunidade, [...] desejo, [...] estímulo algum de exercitar e realizar a superioridade das forças deles sobre os indivíduos dessa sociedade, senão alguma vez apenas por acaso, de modo escarso e passageiro" ${ }^{147}$. Nesse sentido, o que eles buscam obter, não ocorre à custa da sociedade e tampouco de qualquer indivíduo: algo alheio à sociedade com pouca estreiteza ou "insuficiente" [scarsa]. Daí a impossibilidade de no exercício do comando e patrimônio da força, possa-se impor "projetos" [progett] e sustentar a felicidade de quem comanda, valendo-se dos bens dependentes e pertencentes, de algum modo, à própria sociedade, percebendo assim de ser algo "fora dos olhos" [fuori degli occhi] e também do pensamento na maior parte do tempo ${ }^{148}$.

As "sociedades humanas" se difereciam daquelas naturais e "passageiras", como concebe Leopardi, na qual os efeitos da "discordia" são acidentais e momentâneos, pois depois de realizada a exigência temporária de "comunhão", logo se dissolve tal "sociedade", não permitindo assim a continuidade do efeito nefasto entre os da mesma espécie ${ }^{149}$. O mesmo não ocorre naquelas humanas, na qual os "mais fortes" [più fortt] não se ocupam de outra coisa senão o "fazer o mal aos mais fracos e à sociedade, e a superioridade em qualquer força é sempre danosa aos outros, porque sempre

\footnotetext{
147 LEOPARDI, Giacomo. Zibaldone di pensieri, fragmento $3781,25.10 .1823$, in: Tutte le poesie, tutte le prose e lo Zibaldone, p. 2194: "i più forti non hanno nè mezzo [...] occasione [...] desiderio [...] stimolo alcuno di esercitare e porre in opera la superiorità delle loro forze sopra gl'individui di essa società, se non solamente alcuna volta per accidente, in modo scarso e passeggero".

${ }^{148}$ Cf. LEOPARDI, Giacomo. Zibaldone di pensieri, fragmento 3781, 25.10.1823, in: Tutte le poesie, tutte le prose e lo Zibaldone, p. 2194.

${ }^{149}$ Cf. LEOPARDI, Giacomo. Zibaldone di pensieri, fragmento 3782, 25.10.1823, in: Tutte le poesie, tutte le prose e lo Zibaldone, p. 2194.
} 
(pelo menos hoje em dia, e no passado muito mais vezes) adotada para o único bem de quem a possuí[a]"150.

O mesmo não ocorre na "sociedade estreita", segundo comenta Leopardi, "pondo os indivíduos em contato uns com os outros, dá necessariamente o essor ao ódio inato de cada vivo para com o outro, cujo ódio em nenhum animal é tanto, nem sequer com os indivíduos de espécie diferente e naturalmente inimiga, como ele é nos indivíduos de uma sociedade estreita para com os outros indivíduos da mesma sociedade" ${ }^{151}$. Ademais, nesse gênero de "sociedade", o ódio aumenta com a presença do "objeto odiado" [oggetto odiato] e das suas ações, em especial sendo, esse ódio algo já natural, de modo que por natureza não pode nunca ser deposto, pois se encontra na natureza de todo vivo. Mesmo quando a "sociedade estreita" administra as ocasiões de exercitar esse ódio, torna-se algo muito fatal e danoso para a espécie: o mesmo não ocorrendo em uma espécie sem "sociedade" ou de "sociedade ampla", mesmo porque a natureza não quis que nenhuma espécie, menos ainda a humana, morresse pelas próprias mãos, ou seja, pelos seus próprios indivíduos ${ }^{152}$.

Para Leopardi aqui se apresentam evidentes "contradições" [contraddizioni] e bastante formais, excluídas de todo "raciocínio absoluto" [ragionamento assoluto]. Nesse sentido, Leopardi argumenta:

o próprio princípio da nossa razão, ou se reconhece como falso, e não podemos mais discorrer, ou impede de supor essas contradições na natureza; as quais, porém, teria necessariamente lugar nele, se ela tivesse querido em qualquer espécie uma sociedade estreita, embora sempre em uma sociedade estreita, qualquer que tenha sido ou

150 LEOPARDI, Giacomo. Zibaldone di pensieri, fragmento 3782, 25.10.1823, in: Tutte le poesie, tutte le prose e lo Zibaldone, p. 2194: "i più forti non servono ad altro che a far male ai più deboli e alla società, e la superiorità qualunque di forze è sempre dannosa altrui, perchè sempre (almeno oggidì, e per lo passato il più delle volte) adoperata in solo bene di chi la possiede".

151 LEOPARDI, Giacomo. Zibaldone di pensieri, fragmento 3782, 25.10.1823, in: Tutte le poesie, tutte le prose e lo Zibaldone, p. 2194: "ponendo gl'individui a contatto gli uni degli altri, dà necessariamente l'essor all'odio innato di ciascun vivente verso altrui, il qual odio in nessuno animale è tanto, neppur vero gl'individui di specie diversa e naturalmente nemica, quanto egli è negl'individui di una società stretta verso gli altri individui della medesima società".

152 Cf. LEOPARDI, Giacomo. Zibaldone di pensieri, fragmentos 3783-3784, 25.10.1823, in: Tutte le poesie, tutte le prose e lo Zibaldone, p. 2194. 
seja, ou seja por ser a sua forma, tenham ocorrido e terão lugar as coisas acima ditas ${ }^{153}$.

Daí Leopardi deduzir que, ao se supor na natureza a intenção de uma "sociedade estreita" em qualquer espécie, em especial, na humana que, de um lado, sendo a primeira, devia ser a mais feliz e perfeita, de outro, uma "sociedade estreita" está necessariamente sujeita a esses "inconvenientes" [inconvenienti], é algo que repugna ao próprio princípio da razão ${ }^{154}$. Para Leopardi, o ódio para com os outros não é obra da natureza, mas resulta do amor próprio, cujo "amor" é um bem sumamente necessário, pois nasce em si mesmo da exitência sentida: "seria contradição um ser que sentisse de existir e não se amasse" 155 .

Com base nessas evidências, Leopardi realiza outras inferências que atestam a contradição de uma "sociedade estreita", uma vez que ela

\begin{abstract}
põe necessariamente em oposição os interesses dos indivíduos, torna necessário à satisfação dos desejos de uns, e o mal de outros, a superioridade, as vantagens, a felicidade de uns, a inferioridade, as desvantagens, a infelicidade dos outros; desperta o desejo de bens que não se pode conseguir sem o mal de outros, de bens que consistem no mal de outros, que correspondem pela natureza deles a outros tantos males [...] de outros indivíduos ${ }^{156}$.
\end{abstract}

Por conseguinte, uma "sociedade estreita" prejudica necessariamente a maior parte, pois os mais "fracos" [deboli] é sempre a maioria dos indivíduos: algo

153 LEOPARDI, Giacomo. Zibaldone di pensieri, fragmento 3784, 25.10.1823, in: Tutte le poesie, tutte le prose e lo Zibaldone, pp. 2194-2195: "il principio stesso della nostra ragione, o si riconosce per falso, e non possiamo più discorrere, o impedisce di supporre queste contraddizioni nella naturza; le quali però vi avrebbero necessariamente luogo s'ella avesse voluto in qualunque specie una società stretta, siccome sempre in una società stretta, qualunque sia stata o sia o sia per essere la sua forma, hanno avuto ed avranno luogo le cose sopraddescrite".

${ }^{154}$ Cf. LEOPARDI, Giacomo. Zibaldone di pensieri, fragmento 3784, 25.10.1823, in: Tutte le poesie, tutte le prose e lo Zibaldone, p. 2195.

155 LEOPARDI, Giacomo. Zibaldone di pensieri, fragmento 3784, 25.10.1823, in: Tutte le poesie, tutte le prose e lo Zibaldone, p. 2195: "sarebbe contraddizione un essere che sentisse di essere e non si amasse".

${ }^{156}$ LEOPARDI, Giacomo. Zibaldone di pensieri, fragmento 3785-3786, 25.10.1823, in: Tutte le poesie, tutte le prose e lo Zibaldone, p. 2195: "pone necessariamente in contrasto gl'interessi degl'individui, rende necessario alla soddisfazione dei desiderii degli uni, il male degli altri; alla superiorità, ai vantaggi, alla felicità degli uni, l'inferiorità, gli svantaggi, l'infelicità degli altri; desta il desiderio di beni che non si possono conseguire senza il male degli altri, di beni che consistono nel male altrui, che corrispondono per lor natura ad altrettanti mali [...] degli altri individui". 
contrário, portanto, à finalidade essencial da sociedade que visa o "bem comum" [bene comune] dos seus indivíduos ou da maioria"157.

Por isso a "sociedade estreita" repugna, como explicita Leopardi, a natureza em geral, mas também a própria noção de sociedade: algo contra as intenções da natureza. Se o ódio presente no ser vivo já expressa algo de antisocial por natureza, em razão da "sociedade estreita", se torna, no entender de Leopardi, mais infinitamente antisocial, pois odiava, de princípio, quase apenas em potência, mas nessa "sociedade" odeia em ato. Nesse sentido, Leopardi sustenta: ao se dizer "sociedade estreita, em especial humana, é contradição, não só com relação à natureza etc., mas absolutamente, com relação a si mesma, nos termos, e com respeito à noção dessas palavras" ${ }^{158}$. Contudo Leopardi assegura de não existir nenhuma "forma de sociedade perfeita" [forma alcuna di società perfetta] desde aquela primitiva e fora dela, pois a "ideia dessas formas é contraditória por natureza" ${ }^{159}$. Ademais aquela primeira sociedade não se pôde e nem se poderá jamais substituir, pois "a natureza unviversal [...] não se substitui, nem se substitui a felicidade e a perfeição destinada a qualquer ser ou espécie pela natureza"160.

Para Leopardi, toda espécie e ser criado é capaz apenas de uma única e determinada felicidade, perfeição a qual não se pode encontrar em qualquer lugar, pois apenas no seu estado natural. Ademais não deriva de nenhum outro lugar, porque não quis "o destino e nem comporta a natureza das coisas que [...] nenhuma espécie e nenhum ser mortal [...] deva conduzi-lo à própria felicidade e perfeição [...]"161. Esse discurso leopardiano se conclui, excluindo a

157 Cf. LEOPARDI, Giacomo. Zibaldone di pensieri, fragmento 3786, 25.10.1823, in: Tutte le poesie, tutte le prose e lo Zibaldone, p. 2195.

158 LEOPARDI, Giacomo. Zibaldone di pensieri, fragmento 3788, 25.10.1823, in: Tutte le poesie, tutte le prose e lo Zibaldone, p. 2195: "società stretta, massime umana, è contraddizione, non solo rispetto alla natura ec., ma assolutamente, rispetto a se stessa, ne' termine, e rispetto alla nozione di queste parole".

159 LEOPARDI, Giacomo. Zibaldone di pensieri, fragmento 3788, 25.10.1823, in: Tutte le poesie, tutte le prose e lo Zibaldone, p. 2196: "idea medesima d'esse forme è contraddittoria per natura".

160 LEOPARDI, Giacomo. Zibaldone di pensieri, fragmento 3788, 25.10.1823, in: Tutte le poesie, tutte le prose e lo Zibaldone, p. 2196: "la natura universale, [...] non si rimpiazza, nè si rimpiazza la felicità e la perfezione destinata a qualsivoglia essere o specie dalla natura".

${ }^{161}$ LEOPARDI, Giacomo. Zibaldone di pensieri, fragmentos 3788-3789, 25.10.1823, in: Tutte le poesie, tutte le prose e lo Zibaldone, p. 2196: "il destino, nè comporta la natura delle cose che $[\ldots]$ niuna specie e niuno essere mortale [...] dee condurlo alla propria felicità e perfezione". 
"sociedade estreita", "não apenas da espécie humana, mas de todas as espécies vivas [...], excluindo a sociedade estreita, em especial, da espécie humana"162. Uma "sociedade estreita" de homens prejudica muito mais do que qualquer outra espécie, pois a experiência de todas as nações e de todos os séculos demonstraram a efetivação do ódio, que antes existia em potência na natureza, "entre as classes, entre as castas, entre as ordens, as campanhas, os povos" ${ }^{\prime 163}$. Decorre também dela a guerra contínua e cruel: a morte de semelhantes.

Leopardi recorda os infinitos males, como as "mutilações" [mutilazioni] em que os hábitos e as necessidades pertencentes a essa sociedade provocam "a devastação dos campos e a ruína das cidades, a carestia, além das pestes" ${ }^{\prime 164}$. São males que pertencem, sobretudo, ao homem em uma "socieade como é a presente" [una società com'è la presente]. Isso justifica também as considerações no Discorso de 1824, no qual Leopardi identifica a fragilidade dos princípios no trato entre os indivíduos: a completa aparência de realidade.

\subsection{A diagnose leopardiana do presente: Leopardi filósofo social ou metafísico?}

Como crítico do século XIX, Leopardi diagnostica certas degenerescências decorrentes dos rumos tomados pela racionalidade e civilidade inerente ao mundo moderno. Daí a relevância do Discorso de 1824, pois revela uma complexidade no modo de abordar os danos da experiência moderna. Em um dos fragmentos do Zibaldone di pensieri, datado em 7 de julho de 1826, Leopardi sustenta:

A barbárie supõe um princípio de civilização, uma civilização iniciada, imperfeita; aliás, o inclui. O estado

\footnotetext{
162 LEOPARDI, Giacomo. Zibaldone di pensieri, fragmento 3789, 25.10.1823, in: Tutte le poesie, tutte le prose e lo Zibaldone, p. 2196: "non solo dalla specie umana, ma da tutte le specie viventi [...] esclude la società stretta, dalla specie umana massimamente".

163 LEOPARDI, Giacomo. Zibaldone di pensieri, fragmento 3790, 25.10.1823, in: Tutte le poesie, tutte le prose e lo Zibaldone, p. 2196: "fra classe e classe, ceto e ceto, ordine e ordine, compagnia e compagnia, popolo e popolo".

164 LEOPARDI, Giacomo. Zibaldone di pensieri, fragmento 3793, 25.10.1823, in: Tutte le poesie, tutte le prose e lo Zibaldone, p. 2197: "la devastazione de' campi, e ruina delle città, e le carestie, oltre le pesti".
} 
selvagem puro, não é nada bárbaro. As tribos selvagens da América que se destroem reciprocamente com guerras mortíferas, e se extinguem igualmente por si mesmas por força de embriaguez, não fazem isso porque são selvagens, mas porque têm um princípio de civilização, uma civilização imperfeitíssima e muito rude; porque iniciaram a civilizar, em suma, porque são bárbaras. $O$ estado natural não ensina isto, e não é o deles. O mal deles provém de um princípio de civilização. Nada pior, certamente, que uma civilização ou iniciada, ou [...] amadurecida, degenerada, corrupta. Uma e outra são estados bárbaros, mas nem uma nem a outra são estado selvagem puro e propriamente dito ${ }^{165}$.

Em seu Discurso sobre o estado presente dos costumes dos italianos [Discorso sopra lo stato presente dei costumi degl'italiani] ${ }^{166}$, Leopardi concebeu o processo civilizatório moderno como uma experiência de perda, fragilização e degenerescência da condição humana. Tal processo determinou a eliminação de valores e de crenças fundamentais, seja para a constituição do ânimo humano seja para a vida civil. Ele questionou como as sociedades modernas puderam sobreviver ante o vazio deixado pelo processo de civilização destruidor de "crenças" [credenze] e de "opiniões" [opinioni], com base nas quais se fundamentavam os princípios morais e o "exercício da virtude" [esercizio della virtü ${ }^{167}$.

O reconhecimento leopardiano da importância das ilusões dá-se em razão de elas possibilitarem ao gênero humano uma experiência vital oposta à experiência dos limites da realidade. Nesse sentido, as ilusões não são tomadas como "meras inutilidades" [mere vanità]. Elas são "necessárias, e

${ }^{165}$ Cf. LEOPARDI, Giacomo. Zibaldone di pensieri, fragmento 4185, 07.07.1826, p. 2311: "La barbarie suppone un principio di civiltà, una civiltà incoata, imperfetta; anzi l'include. Lo stato selvaggio puro, non è punto barbaro. Le tribù selvagge d'America che si distruggono scambievolmente con guerre micidiali, e si spengono altresì da se medesime a forza di ebrietà, non fanno questo perchè sono selvagge, ma perchè hanno un principio di civiltà, una civiltà imperfettissima e rozzissima; perchè sono incominciate ad incivilire, insomma perchè sono barbare. Lo stato naturale non insegna questo, e non è il loro. Il loro mali provengono da un principio di civiltà. Niente di peggio certamente, che una civiltà o incoata, o [...] matura, degenerata, corrota. L'una e l'altra sono stati barbari, ma nè l'una nè l'altra sono stato selvaggio puro e propriamente detto".

${ }^{166}$ Cf. LEOPARDI, Giacomo. Discorso sopra lo stato presente dei costumi degl'italiani, pp. $45-$ 84.

${ }^{167}$ Cf. LEOPARDI, Giacomo. Discorso sopra lo stato presente dei costumi degl'italiani, pp. 4584. 
entram substancialmente na composição e ordem das coisas" ${ }^{168}$, pois somente por seu intermédio torna-se possível "buscar no homem a única espécie de certa felicidade da qual ele é capaz. A verdadeira sabedoria [...] de buscar a felicidade no ideal" ${ }^{169}$. Ante o "vazio da existência" provocado pela presença do "nada" [nulla] - que Leopardi chama de "fantasma horrível" [fantôme affreux] ${ }^{170}$ - são necessárias as ilusões.

Como obra da natureza, a imaginação e as ilusões possibilitaram ao homem antigo ser grande, generoso e heróico. Sempre inferior a este, porém, é o homem moderno: pequeno, egoísta e vil, porque segue a razão. O desenvolvimento da razão e a civilização são a consequência negativa da transformação da condição do espírito humano, pois não permitem mais uma relação imediata, direta e espontânea com a natureza, própria aos tempos primitivos. Daí a importância da "imaginação" [immaginazione], por se tratar de uma faculdade que conserva no homem parte da sua ação e da sua influência. Tal faculdade não tem lugar, entretanto, na situação em que se apresenta uma "dissipação diária e contínua, sem sociedade" [dissipazione giornaliera e continua $^{171}$. Disso resulta somente o tédio diante da impossibilidade de vida ativa no presente.

Sem ilusões, mediante as quais o homem é persuadido, "não há [entretanto] vida, nem ação" ${ }^{172}$. Isso ocorre porque "o homem não opera sem persuasão"173. Quando a persuasão, por sua vez, não é ilusória, mas decorre da razão, "o homem não opera, porque a razão não o persuade a operar, aliás, o dissuade e o lança na indiferença" ${ }^{174}$. Aqui se revela a insistência leopardiana

168 Cf. LEOPARDI, Giacomo, Zibaldone di pensieri, fragmento 51, 08.01.1820, p. 1489: "necessari ed entrano sostanzialmente nel composto ed ordine delle cose".

${ }^{169}$ Cf. LEOPARDI, Giacomo. La vita e le lettere [1810-1835]. Milano: Garzanti, 1983, p. 252.

${ }^{170}$ Cf. G. Leopardi. Epistolario (23.06.1823), in Tutte le poesie, tutte le prose e lo Zibaldone, p. 1251.

${ }^{171}$ Cf. LEOPARDI, Giacomo. Discorso sopra lo stato presente dei costumi degl'italiani, p. 62

172 Cf. LEOPARDI, Giacomo, Zibaldone di pensieri, fragmentos 362-363, 29.11.1820, p. 1568. Uma exposição sobre a teoria do gênero e da tradução no interior do Zibaldone di pensieri, assim como uma interpretação desses temas pela crítica literária nacional e estrangeira, se encontram no estudo de GUERINI, Andréia. Gênero e tradução no Zibaldone de Leopardi. São Paulo: Edusp; Florianópolis: UFSC/PGET, 2007.

173 Ibidem.

${ }^{174}$ Ibidem. 
de afirmar a dimensão espiritual presente nos sentimentos e de reconhecer a ameaça que constitui a forma de proceder da razão na experiência dos novos tempos.

O homem pertencente a tal século é alguém destituído de "força da imaginação" [forza della immaginazione ${ }^{175}$, pois "cada vez mais se enfraquecem as gerações dos homens, pela falta de ilusões existentes no mundo como outrora"176. A vitalidade e a "necessidade do vigor do corpo" [necessità del vigor del corpo] só podem provir com a presença das "grandes ilusões da alma" [grandi illusioni dell'animo] ${ }^{177}$. Todavia, insiste Leopardi: "as ilusões [...] duram ainda a despeito da razão e do saber. É de se esperar que durem também no progresso" ${ }^{178}$. Na presente condição dos homens [presente condizione degli uomini] apresentam-se, de um lado, o "incremento e a divulgação da Filosofia, que nos vai afiando e dispersando todo aquele pouco que nos resta [de ilusões] e, de outro, a ausência positiva de quase todos os objetos de ilusão" 179 . Daí se justifica a presença da "uniformidade" [uniformità], da "inatividade" [inattività], da "nulidade" [nullità] e "mortificação real" [mortificazione reale] da vida.

As ilusões não são, no entender de Leopardi, "obra da arte ou da razão, mas da natureza" ${ }^{180}$. Disto segue que a sua destruição, por obra da razão moderna, afeta a natureza que constitui a força vital nos homens. O resultado dessa mutilação é, portanto, o surgimento da barbárie, pois esta última é a condição em que a própria natureza perde a sua força nos homens. A razão

175 O autor compreende a ausência de "força da imaginação" como algo decorrente da perda de vigor própria do século da razão. Isto ocorre em virtude do modo com o qual se realiza a formação "moderna", que fragiliza o ânimo com o excesso de exercícios da razão, e enfraquece as disposições ligadas à vitalidade do corpo. Sobre esta questão, ver LEOPARDI, Giacomo. Il Parini ovvero della Gloria, in: Operette Morali (a cura di Cesare Galimberti), pp. 249-295.

176 Cf. LEOPARDI, Giacomo, Zibaldone di pensieri, fragmento 130, 22.06.1820, p.1514: "s'infiacchiscono sempre più le generazioni degli uomini, e questo effetto della mancanza d'illusioni esistenti nel mondo come una volta".

177 Cf. LEOPARDI, Giacomo. Zibaldone di pensieri, fragmento 130, 22.06.1820, p. 1514.

178 Cf. LEOPARDI, Giacomo, Zibaldone di pensieri, fragmento 216, 18-20.08.1820, p.1537: "le illusioni [...] durano ancora a dispetto della ragione e del sapere. È da sperare che durino anche in progresso".

179 Ibidem.

${ }^{180}$ Cf. LEOPARDI, Giacomo. La vita e le lettere, p. 164. 
moderna, porém, "em oposição à razão antiga, não observa e não consulta senão o verdadeiro, algo diverso da natureza"181. A natureza, não obstante a sua fragilização na experiência moderna, é "desmensuradamente mais forte do que a razão" [smisuratamente più forte della ragione], podendo ainda enfrentar a sua "inimiga" [nemica $]^{182}$.

Para Leopardi, a natureza deliberou as ilusões para os homens, como criações arbitrárias, já que ela poderia se conduzir normalmente sem as mesmas. Disso segue que as ilusões - constituidoras do homem como tal e da ordem das coisas - são compreendidas "como algo de certo modo real" [come cosa in certo modo reale] ${ }^{183}$. Elas são os "ingredientes essenciais do sistema da natureza humana" [ingredienti essenciale del sistema della natura umana] ${ }^{184}$ e naturalmente dadas a todos os homens de forma que "não é lícito desprezálas como sonhos de um apenas, mas verdadeiramente próprias do homem e, [portanto], queridas pela natureza"185. Por que tal dimensão das ilusões é aqui destacada como necessária e posta pela natureza nos homens? Qual a sua função no interior da reflexão leopardiana sobre a problemática do presente?

A atividade da faculdade imaginativa (atributo natural do homem), por causa da falta de felicidade real, se apresenta como essencialmente necessária, tendo em vista a incapacidade de todos os prazeres satisfazerem integralmente o homem. Enquanto ela possibilita suprir em certa medida essa falta, a sua atividade faz que todos "pareçam belíssimos e grandes de longe, e o desconhecido seja mais belo do que o conhecido" ${ }^{186}$. Desse modo, as ilusões terminam persuadindo os homens a ações grandiosas e virtuosas (conforme o seu próprio caráter), pois Leopardi compreende "que a virtude, [...] como tudo aquilo que é grande e belo, seja apenas uma ilusão" 187 .

\footnotetext{
181 Ibidem, p. 165.

${ }^{182}$ Cf. LEOPARDI, Giacomo. Zibaldone di pensieri, frangmento 215, 18-20.08.1820, p. 1537.

${ }^{183}$ Cf. LEOPARDI, Giacomo. Zibaldone di pensieri, fragmento 51, 08.01.1820, p. 1489.

${ }^{184}$ Cf. LEOPARDI, Giacomo. Zibaldone di pensieri, fragmento 51, 08.01.1820, p. 1489.

185 Ibidem: "non è lecito spregiarle come sogni di un solo, mas propri veramente dell'uomo e voluti dalla natura".

${ }^{186}$ Cf. LEOPARDI, Giacomo. Zibaldone di pensieri, fragmento 170, 23.07.1820, p.1525: "paiono bellissimi e sommi da lontano, e ignoto sia più bello del noto".

${ }^{187}$ LEOPARDI, Giacomo. La vita e le lettere, p. 251.
} 
No entender de Leopardi, "o mais sólido prazer desta vida é o vão prazer das ilusões" 188 . Daí resulta a presença delas na experiência humana, pois o homem "não vive de outra coisa senão [...] de ilusões" ${ }^{189}$. Leopardi identifica, nesta afirmação, uma "proposição exata e incontrastável: [pois] tolhida [...] as ilusões radicalmente" ${ }^{190}$, a existência humana permanece algo insuportável. Por conseguinte, elas assumem, no âmbito da vida humana, um lugar determinante, uma vez que possibilitam ao homem a continuidade de sua existência: um alimento para a vida. Elas conduzem também à realização de grandes ações, pois a maior parte das ações não pode provir "senão da ilusão" [se non da illusioni $]^{191}$.

As ilusões procuram suprir, de acordo com Leopardi, em certa medida, a falta de felicidade real dos homens (dada à inclinação da natureza humana ao prazer infinito, porém, irrealizável), estimulando, assim no ânimo deles, ações e pensamentos nobres e virtuosos. Tais pensamentos, como produtos da faculdade imaginativa, são compreendidos como algo que expressa sentido e apreço à vida, pois objetivam atingir o bem comum dos homens. Tantos obstáculos ameaçam, entretanto, a vitalidade e a conservação das ilusões no universo da experiência existencial humana e, em especial, naquela do mundo moderno.

Se, porém, os princípios ressuscitassem as "ilusões" [illusioni]? Eles dariam "vida e espírito" [vita e spirito] aos povos, reanimariam com certa "substância" [sostanza] e "realidade" [realtà] os "erros e as imaginações constituidoras e fundamentais das nações e das sociedades" ${ }^{192}$. Desse modo, todas as nações certamente "adquiririam, ou melhor, renasceriam para a vida, e se tornariam grandes, fortes e formidáveis" ${ }^{193}$. Ante a "mísera

\footnotetext{
${ }^{188}$ Cf. LEOPARDI, Giacomo. Zibaldone di pensieri, fragmento 51, 08.01.1820, p. 1489.

${ }^{189}$ Cf. LEOPARDI, Giacomo. Zibaldone di pensieri, fragmento 216, 18-20.08.1820, p.1537: "non vive d'altro che [...] d'illusioni".

190 Ibidem: "proposizione esatta e incontrastabile: Tolta [...]le illusioni radicalmente".

191 Cf. LEOPARDI, Giacomo. Zibaldone di pensieri, fragmento 105, 26.03.1820, p.1507.

192 Cf. LEOPARDI, Giacomo. Zibaldone di pensieri, fragmento 1026, 10.05.1821, p. 1693: "gli errori e le immaginazioni costitutrici e fondamentali delle nazioni e delle società".

193 Ibidem: "acquistirebbero, o piuttosto, risorgerebbero a vita, e diverrebbero grandi e forti e formidabili".
} 
espiritualização" [misera spiritualizzazione] das coisas humanas, Leopardi percebe a necessidade de se recuperar as "ilusões" [illusioni], ou seja, a "pátria" [pátria], o "triunfo" [trionfo], as "festas patrióticas" [feste patriotiche], as "honras e méritos" [onori renduti al merito]: todas pertencentes ao mundo antigo ${ }^{194}$. Só assim as nações ressurgiriam para a vida e se tornariam grandes e fortes ${ }^{195}$.

Opondo-se ao caráter efêmero das obras modernas, Leopardi lembra a "poderosa solidez das antigas construções de todo gênero, construções que ainda vivem, enquanto as nossas, também públicas, não serão certamente vistas pelos pósteros muito distantes" ${ }^{196}$. Destacam-se, entre elas, as pirâmides, os obeliscos, os arcos do triunfo, a forma antiga de cunhar as medalhas e moedas, pois, depois de tantos anos, permanecem vivas. Tudo isso é resultado, prova e sinal das "antigas ilusões [...], da antiga força e domínio da imaginação" 197 .

Para Leopardi, tudo é "vacuidade" [vanità], menos as "belas ilusões" [belle illusioni]. Sem as "ilusões" [illusioni] não pode haver grandeza, nem o que se esperar ${ }^{198}$. Nos novos tempos, em virtude do predomínio de uma racionalidade inimiga de toda grandiosidade, ocorreu a destruição das "grandes ilusões" [grandi illusioni] e, por sua vez, a destruição da "grandeza de espírito" [grandezza d'animo] e das "ações" [azioni]. O progresso da razão e a dissolução das ilusões produzem a "barbárie" [barbárie], pois "um povo iluminado em excesso, não se torna civil, como sonham os filósofos do nosso tempo [...], mas bárbaro" 199 .

\footnotetext{
194 Cf. LEOPARDI, Giacomo. Zibaldone di pensieri, fragmento 1026, 10.05.1821, p. 1693.

${ }^{195}$ Cf. LEOPARDI, Giacomo. Zibaldone di pensieri, fragmento 1026, 10.05.1821, p. 1693.

196 Cf. LEOPARDI, Giacomo. Zibaldone di pensieri, fragmento $3435,15.09 .1823$, p. 2127 : "portentosa solidità delle fabbriche d'ogni genere, fabbriche che ancor vivono, mentre le nostre, anche pubbliche, non saranno certo vedute da posteri molto lontani".

197 Ibidem: "antiche illusioni [...] dell'antica forza e dominio d'immaginazione".

${ }^{198}$ Cf. LEOPARDI, Giacomo. Zibaldone di pensieri, fragmento 15, 12.1818, p.1470.

${ }^{199}$ Cf. LEOPARDI, Giacomo. Zibaldone di pensieri, fragmento 22, 12.1818, p. 1474: "un popolo oltremodo illuminato non diventa mica civilissimo, come sognano i filosofi del nostro tempo, [...] ma barbaro".
} 
Antes da crise leopardiana do "sistema da natureza" [sistema della natura], a "grande inimiga da barbárie não era a razão, mas a natureza" ${ }^{200}$. A "natureza" [natura] fornece as "ilusões" [illusioni] a fim de tornar um povo realmente "civil" [civile]. "As ilusões são, por natureza, inerentes ao sistema do mundo, [quando] eliminadas [...] o homem se degenera; todo povo degenerado é bárbaro, não podendo mais as coisas mover-se como o quer o sistema do mundo" 201 . Para Leopardi, a "razão" [ragione] é uma "luz" [lume] e a natureza quer ser iluminada, mas não incendiada por ela ${ }^{202}$. Ao tornar os homens "amigos do útil" [amici dell'utile] ${ }^{203}$, eliminando as ilusões que os ligam uns aos outros, a razão dissolveu a sociedade e tornou as pessoas ferozes.

Leopardi sabia que o tempo das "grandes ilusões" [grandi illusioni] teria terminado ${ }^{204}$. Sabia também ser "verdadeiro" [vero], mesmo o real sendo um "nada" [nulla], pelo fato de não existir "outro real, nem outra coisa de substancial no mundo do que as ilusões"205. Todo o "belo" [bello], o "bom" [buono], neste mundo, é ilusão, mas também a "virtude" [virtù], a "magnanimidade" [magnanimità] são "fantasmas e substâncias imaginárias" [fantasmi e sostanze immaginarie] ${ }^{206}$. O império da "pura razão" [pura ragione] é o império do despotismo, pois a "razão pura" [pura ragione] dissipa as ilusões e conduz ao egoísmo. Tal razão pôs em risco o viver civil porque divide os indivíduos e as nações.

Embora as "ilusões" [illusioni] tivessem sido enfraquecidas e desmascaradas pela razão, Leopardi sabe que ainda permanecem no mundo, uma vez que compõem nossa vida. Daí não bastar ter o conhecimento de tudo para perdê-las, mesmo sabendo da vacuidade delas. Ademais, mesmo

\footnotetext{
200 Ibidem: "più gran nemica della barbarie non è la ragione ma la natura".

201 Ibidem: "Le illusioni sono in natura, inerenti al sistema del mondo, [...] tolte via [...] l'uomo è snaturato; ogni popolo snaturato è barbaro, non potendo più correre le cose come vuole il sistema del mondo".

202 Cf. LEOPARDI, Giacomo. Zibaldone di pensieri, fragmento 22, 12.1818, p. 1474.

${ }^{203}$ Cf. LEOPARDI, Giacomo. Zibaldone di pensieri, fragmento 23, 12.1818, p. 1475.

${ }^{204}$ Cf. LEOPARDI, Giacomo. Zibaldone di pensieri, fragmento 85, 08.01.1820, p. 1500.

${ }^{205}$ Cf. LEOPARDI, Giacomo. Zibaldone di pensieri, fragmento 89, 08.01.1820, p. 1505: "non v'è altro di reale nè altro di sostanza al mondo che le illusioni".

${ }^{206}$ Cf. LEOPARDI, Giacomo. Zibaldone di pensieri, fragmento 125, 16.06.1820, p. 1512.
} 
perdidas, permanece ainda uma "raiz muito vigorosa" [radice vigorosissima], pois as ilusões continuam vivendo, não obstante a experiência e a certeza de sua perda. "Eu vi pessoas muito sábias, muito experientes, cheias de conhecimento, de saber e de filosofia, muito infelizes, perder todas as ilusões, e desejar a morte como único bem, e [...] aos seus amigos" ${ }^{207}$.

O homem, portanto, não vive de outra coisa senão de "ilusões" [illusioni]. Se fossem eliminadas radicalmente, todo homem ou criança se mataria e "a nossa raça teria sido extinta no seu nascimento por necessidade inata e substancial”"208. As ilusões, porém, ainda permanecem, não obstante a presença da "razão" [ragione] e do "saber" [sapere]. Leopardi "espera" que durem mesmo com o progresso. Os riscos contra as "ilusões" [illusioni] mostram-se, contudo, na condição presente dos homens: "do crescimento e divulgação da Filosofia, de um lado, a qual vai afinando e dissipando todo aquele pouco que nos resta; e de outro [...] a falta positiva de quase todos os objetos de ilusão, e da mortificação real, uniformidade, inatividade, nulidade [...] de toda a vida"209.

Tais coisas conduzirão os homens a perder todas as "ilusões" [illusioni], e "perdê-las para sempre, pois terão diante dos olhos, continuamente e sem intervalo, a pura e nua verdade: da raça humana não restarão outra coisa senão os ossos, como de outros animais" ${ }^{210}$. Não houve em nenhum momento da história semelhante destruição, não houve em outras idades semelhante exemplo, fruto "dos progressos de um processo civilizatório desmedido e de

\footnotetext{
${ }^{207}$ Cf. LEOPARDI, Giacomo. Zibaldone di pensieri, fragmento 214, 18-20.08.1820, p. 1537: "ho veduto persone savissime, espertissime, piene di cognizioni di sapere e di filosofia, infelicissime, perdere tutte le illusioni, e desiderar la morte come unico bene, [...] e agli amici".

${ }^{208}$ Cf. LEOPARDI, Giacomo. Zibaldone di pensieri, fragmento 216, 18-20.08.1820, p. 1537: "la razza nostra sarebbe rimasta spenta nel suo nascere per necessità ingenita, e sostanziale".

${ }^{209}$ Cf. LEOPARDI, Giacomo. Zibaldone di pensieri, fragmento 216, 18-20.08.1820, p. 1537: "dell'incremento e divulgamento della filosofia da una parte, la quale ci va assottigliando e disperdendo tutto quel poco che ci rimane; e dall'altra parte della mancanza positiva di quasi tutti gli oggetti d'illusione, e della mortificazione reale, uniformità, inattività, nullità ec. di tutta la vita".

${ }^{210}$ Ibidem: "perderle per sempre, ed avere avanti gli occhi continuamente e senza intervalo la pura e nuda verità, di questa razza umana non resteranno altro che le ossa, come di altri animali di cui si parlò nel secolo addietro".
} 
uma degeneração sem limites"211. Disso resulta também o "sentimento de infelicidade" [sentimento dell'infelicità], oriunda da perda das "grandes e vivas ilusões" [grandi e vive illusioni]. Leopardi vislumbra aqui um universo horrendo de destruição que ameaça a vida no presente moderno. Isto explica a necessidade de uma "filosofia dolorosa" [filosofia dolorosa], pois exalta a importância e o sentido das "ilusões" [illusioni] na vida, em oposição à "seca razão" [secca ragione]. Nesse sentido, ele interroga o filósofo:

Se agora se encontrassem os ossos ou as cinzas de Homero ou de Virgílio etc. o sepulcro etc., que mérito teriam realmente aquelas cinzas, ou segundo a seca razão? $O$ que participaria dos méritos, das virtudes, da glória etc. de Homero etc? Eliminadas as ilusões e os enganos, para que serviriam? Que utilidade real se extrairia deles? ${ }^{212}$

Em verdade, a civilização do homem social e das nações se fundamenta e se compõe essencialmente nos "erros" [errori] e nas "ilusões" [illusioni] ${ }^{213}$ : algo que exprime sentido também de civilidade. As "ilusões" [illusioni] pertencem substancialmente ao sistema natural e à ordem das coisas, por serem essenciais e necessárias à "perfeição do homem" [perfezione dell'uomo] ${ }^{214}$. Não se podem extirpar totalmente as "ilusões" [illusioni], pois, se isso ocorresse, o homem também desapareceria. O desaparecimento das "ilusões gerais" [illusioni generali], entretanto, influi sempre sobre aquelas individuais $^{215}$. Leopardi conhece os rumos tomados pelo processo civilizatório e os danos causados à vida civil, em especial, contra as faculdades e às crenças. Ante as degenerescências do presente, ele faz um alerta:

${ }^{211}$ Cf. LEOPARDI, Giacomo. Zibaldone di pensieri, fragmento 217, 18-20.08.1820, p. 1537: "dei progressi di un incivilimento smisurato, e di un snaturamento senza limiti".

${ }^{212}$ Cf. LEOPARDI, Giacomo. Zibaldone di pensieri, fragmento 471, 03.01.1821, p. 1590: "Se ora si trovassero le ossa o le ceneri di Omero o di Virgilio ec. il sepolcro ec. quelle ceneri che merito avrebbero realmente, e secondo la secca ragione? Che cosa parteciperebbero dei pregi, delle virtù, della gloria ec. di Omero ec.? Tolte le illusioni, e gl'inganni, a che servirebbero? Che utile reale se ne trarrerebbe?".

${ }^{213}$ Cf. LEOPARDI, Giacomo. Zibaldone di pensieri, fragmento 3435, 15-09.08.1823, p. 2127.

${ }^{214}$ Cf. LEOPARDI, Giacomo. Zibaldone di pensieri, fragmento 405, 09-15.12.1820, p. 1577.

${ }^{215}$ Cf. LEOPARDI, Giacomo. Zibaldone di pensieri, fragmento 1864, 07.10.1821, p. 1857: "Vero è che la distruzione delle illusioni generali influisce sempre selle individuali". 
Ou a imaginação restituirá o vigor e as ilusões, recuperarão corpo e substância em uma vida enérgica e móvel, e a vida tornará a ser coisa viva e não morta, e a grandeza e a beleza das coisas tornarão a parecer uma substância, e a religião adquirirá o seu crédito ou este mundo se tornará um serralho de desesperados, e talvez também um deserto ${ }^{216}$.

Em um fragmento do Zibaldone di pensieri, datado em 7 de junho de 1820, Leopardi considerou o grau de civilização de uma nação como resultado de uma combinação entre natureza e razão, mas com o predomínio da natureza ${ }^{217}$. Por isso, ele considera como principal finalidade da civilização moderna reconduzir a civilização ao equilíbrio entre natureza e razão: único capaz de fornecer certa felicidade aos homens no estado social e o mais conforme ao estado das civilizações antigas, sobretudo, grega e romana.

No entender de Leopardi, não foi, porém, o que ocorreu, porque os modernos, pretendendo abolir o que havia de bárbaro nos baixos tempos, aniquilaram também o que nele existia de antigo, ou seja, a existência, o vigor do povo e do indivíduo, o espírito nacional, os exercícios do corpo, a originalidade e variedade de caráter, costumes e hábitos. A moderna civilização terminou por se conduzir ao lado oposto da antiga, pois à força de tanto refinála e aguçá-la, foi além dela e esteve prestes a rompê-la ${ }^{218}$.

A chamada "perfectibilidade" do estado social, como distanciamento da natureza, não conduziu, portanto, à felicidade, mas aprofundou inúmeros males que reforçam a incivilidade. Ao se reportar ao presente estado moderno, Leopardi indaga se a natureza podia racionalmente pôr "tão grandes,

${ }^{216}$ Cf. LEOPARDI, Giacomo. Frammento sul suicidio, in: Operette morali [1824]. Napoli: Guida. p. 586: "O la immaginazione tornerà in vigore, e le illusioni riprenderanno corpo e sostanza in una vita energica e mobile, e la vita tornerà as esser cosa viva e non morta, e la grandeza e la bellezza delle cose torneranno a parere una sostanza, e la religione riacquisterà il suo credito; 0 questo mondo diverrà un serraglio di disperati, e forse anche un deserto". Ver comentário de S. Givone, "Filosofia, poesia e mito in Vico e in Leopardi", in: G. Vattimo (org.). Filosofia '95, Roma-Bari, Gius. Laterza\&Figli, 1996, pp. 101-118.

217 Cf. LEOPARDI, Giacomo. Zibaldone di pensieri, fragmento 114, 07.06.1820, p. 1510: "La civiltà delle nazioni consiste in un temperamento della natura colla ragione, dove quella cioè la natura abbia la maggior parte".

${ }^{218}$ Cf. LEOPARDI, Giacomo. Zibaldone di pensieri, fragmento 162, 10.07.1820, p. 1523. 
numerosos, incríveis obstáculos, para a descoberta de um meio necessário e principal para obter aquela que nós chamamos [...] perfeição e felicidade do gênero humano, isto é, civilização"219. A orientação da experiência moderna do progresso da civilização conduziu muito mais à incivilidade dos homens, à "barbárie" [barbarie] do que à autêntica perfectibilidade, presente apenas no estado natural.

Leopardi reconhece na "perfeição moderna das artes" [moderna perfezione delle arti] a presença de "esforços" [fatiche] e de "misérias" [miserie] necessários à obtenção da moeda para a sociedade: a exigência desde os trabalhos nas minas até o cunho. "Observai quantos homens são necessários para uma infelicidade estável e regular, para doenças, [...] mortes, [...] escravidão (ou gratuita e violenta, ou mercenária), para desastres, para misérias [...], sofrimentos, [...], angústias de toda espécie, [a fim de] obter para outros homens este meio de civilização e pretenso meio de felicidade" ${ }^{220}$.

No entender de Leopardi é insustentável admitir ter a natureza posto o "princípio à perfeição e felicidade dos homens a este preço, isto é, o preço da

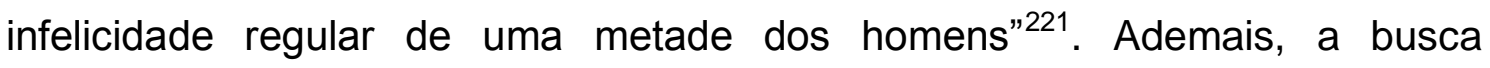
moderna de "civilização" [incivillimento], como perfeição do gênero humano, utiliza-se até da escravidão, defendida por muitos e muitos políticos [...] como necessária ao ócio, à perfeição, ao bem, à civilização da sociedade"222.

Inúmeros foram os desastres e os sofrimentos acumulados na busca incessante de civilização e de felicidade na vida civil moderna. Nesse sentido, Leopardi critica a forma da produção dos "objetos de luxo" [oggetti di lusso] para o "comércio" [commercio] que, efetivamente, não são "por si mesmo[s], nem necessários, nem úteis à vida"223, mas assim mesmo terminam ampliados

\footnotetext{
${ }^{219}$ Cf. LEOPARDI, Giacomo. Zibaldone di pensieri, fragmento 1171-1172, 16.06.1821, p. 1726: "sì grandi, numerosi, incredibili ostacoli al ritrovamento di un mezzo necessario e principale per ottener quella che noi chiamiamo perfezione e felicità del genere umano, cioè l'incivilimento".

220 Ibidem: "Osservate quanti uomini sono necessitati ad una regolare e stabile infelicita, a malattie, a morti, a schiavitù (o gratuita e violenta, o mercenaria), a disastri, a miserie, a pene, a travagli d'ogni sorta, per proccurare agli altri uomini questo mezzo di civiltà, e preteso mezzo di felicita".

${ }^{221}$ Ibidem.

${ }^{222}$ Cf. LEOPARDI, Giacomo. Zibaldone di pensieri, fragmento 1173, 16.06.1821, p. 1726.

${ }^{223}$ Cf. LEOPARDI, Giacomo. Zibaldone di pensieri, fragmento 1183, 18.06.1821, p. 1728.
} 
às custas de "infinitos sofrimentos para a humanidade" [infiniti travagli all'umanità]. A produção desses objetos, em vez de conduzir à civilização e à perfeição, promoveu a incivilidade ou a "barbárie da sociedade" [barbarie della società $^{224}$.

Leopardi compreendeu, também, que o crescimento do mundo determinou, quanto ao indivíduo, o seu estreitamento. "Aplicai este pensamento aos mais diversos aspectos sob os quais se verifica que tendo crescido o mundo 0 indivíduo se tornou pequeno, tanto fisicamente, quanto moralmente"225. Esta diminuição terminou afetando as faculdades da mente humana, pois se tornaram pequenas "na medida em que o mundo [cresceu] em relação a elas"226.

Ao lado dos danos contra o indivíduo, por causa do processo de aperfeiçoamento social, estão aqueles concernentes às "faculdades da mente" [facoltà delle menti]. Muitos "engenhos" [ingegni] extraordinários foram consumidos nesse processo: engenhos produzidos quase por "milagre" [miracolo] pela natureza. Tantos grandes "gênios" [geni] consumiram rapidamente, quer 0 corpo quer as faculdades mentais. "A excessiva delicadeza dos órgãos deles os torna [...] mais fáceis de se consumirem, e mais fáceis a se estragarem, permanecendo inferiores de faculdades com órgãos menos delicados e mais imperfeitos"227. A "perfeita civilização" [perfetta civiltà] não pode subsistir sem a "perfeita barbárie" [perfetta barbarie].

Leopardi compreendeu as diferentes e múltiplas figurações dos danos do mundo moderno: a forma de sua racionalidade que punha em risco outras faculdades humanas; o seu modelo de saber prevalente que terminava danificando a dimensão poética; a destruição dos sentimentos vivos; a

\footnotetext{
${ }^{224}$ Sobre o conceito de barbárie da sociedade, tema central desta Tese ver, LEOPARDI, Giacomo. Zibaldone di pensieri, fragmentos 1183 e 3894, 16.06.1821 e 19.11.1823, pp. 1726, 2224.

${ }^{225}$ Cf. LEOPARDI, Giacomo. Zibaldone di pensieri, fragmento 1176, 16.06.1821, p. 1727: Applicate questo pensiero ai diversissimi aspetti sotto i quali si verifica che essendo cresciuto il mondo, l'individuo s'è impiccolito sì fisicamente che moralmente".

${ }^{226}$ Ibidem.

${ }^{227}$ LEOPARDI, Giacomo. Zibaldone di pensieri, fragmento 1176, 17.06.1821, p. 1727: "La soverchia delicatezza de' loro organi li rende e più facili a consumarsi, e più facili a guastarsi, rimanendo inferiori di facoltà agli organi i meno delicati, e i più imperfetti".
} 
presença do egoísmo; a falsidade das filosofias do progresso e da perfectibilidade; a da cultura espiritualista decorrente da Restauração; a do trato social entre os indivíduos; os riscos contra a integralidade humana, a queda na barbárie. Para Leopardi seria impossível pensar a possibilidade de vida, sem vivos afetos, sem imaginação, sem entusiasmo e, sobretudo, sem ilusões.

É inegável que o diagnóstico leopardiano anunciado, seja nas Operette morali e no Zibaldone di pensieri seja no Discorso, expresse uma mudança na orientação de sua obra. Ademais, Leopardi suspeita de que haja terminado a sua estação poética e que reste apenas a reflexão. Em 12 de maio de 1825, ele retoma esses argumentos e volta a falar de Filosofia, reenviando ao social. Ele escreve: "o filósofo e o homem reflexivo com o hábito da vida social não pode, a menos que seja quase um filósofo de sociedade (ou psicólogo, ou político etc.), com o hábito da solidão se torna necessariamente um metafísico. E se, no início, ele era filósofo de sociedade, em seguida, contraído o hábito da solidão, com o andar do tempo, ele se volta espontaneamente à Metafísica, e finalmente faz dela o principal objeto dos seus pensamentos e o mais favorito e apreciável”228. Tal filósofo metafísico se reporta assim às questões relativas ao homem, abstraindo das dimensões temporais e geográficas, ou seja, concreta, dirigindo-se então à condição humana ${ }^{229}$.

Ademais, a carta a Viesseux de 4 de março de $1826^{230}$, em que recusa 0 convite de colaborar com a Antologia, "o vício da absence é em mim incorrigível e desesperado" [il vizio dell' absence è in me incorriggibile e disperato $^{231}$, expressa, de um lado, certa necessidade de solidão e, de outro, a

\footnotetext{
${ }^{228}$ Cf. LEOPARDI, Giacomo. Zibaldone di pensieri, fragmento 4139, 12.05.1825, p. 2296.

${ }^{229}$ Nesse sentido ver a abordagem de Raimondi sobre a problemática do filósofo social e do metafísico: RAIMONDI, Ezio. Letteratura e identità nazionale. Milano: Mondadori, 2000, pp. $37-$ 38. Para a compreensão de algumas análises leopardianas sobre a modernidade e as relações na vida civil, deve-se aqui destacar alguns escritos que contribuem com essa compreensão: GALIMBERTI, Cesare. Fanciulli e più che uomini, in: LEOPARDI, Giacomo. Pensieri. Milano: Adelphi, 2008, pp. 177-187; RIGONI, Mario Andrea. (org.). Introduzione, in: LEOPARDI, Giacomo. La strage delle illusioni. Pensieri sulla politica e sulla civiltà. Milano: Adelphi, 1992, pp. 9-35; RUSSO, Fabio. I popoli europei visti da Leopardi. In: Leopardi político o della felicita impossibile. Roma: Bulzoni, 1999, pp. 245-271.

${ }^{230}$ LEOPARDI, Giacomo. Epistolario, in: Leopardi. Tutte le poesie, tutte le prose e lo Zibaldone, Roma: Newton\&Compton, 2010, pp. 1310-1311.

${ }^{231}$ LEOPARDI, Giacomo. APUD, TELLINI, Gino. Leopardi, p. 160.
} 
sua proclamada ignorância de tema da filosofia social em que exprime bem mais a sua recusa de não integrar-se a certa prática, ou "sistema operativo (com consequente pedagogia instrumental) caro a Viesseux" ${ }^{\text {"232. }}$.

Leopardi já havia expresso algo de "filosofia social" em seu Discorso de 1824, quando apresentou o seu diagnóstico - expresso à maneira de um etnólogo que traça um quadro histórico e antropológico do estado presente italiano e europeu -, revelando a inconsistência do "espírito nacional" italiano, ou seja, o de seu senso civil. Esse quadro, como foi apresentado na exposição deste capítulo, indica a inexistência da "sociedade estreita" [società stretta], ou seja, aquela que se rege com base no bon ton, nas boas maneiras, na honra, em suma, valendo-se das conveniências e convenções formais do viver civil. Daí resultar na presença apenas do individualismo, do egoísmo, do cinismo e do recíproco escárnio ${ }^{233}$.

Trata-se, portanto, no entender de Leopardi, de uma situação de anarquia ${ }^{234} \mathrm{em}$ que cada um fa tuono e maniera da sè ${ }^{235}$. Daí Leopardi elaborar uma reflexão mais ampla, ou seja, aquela sobre as consequências decorrentes do desenvolvimento da "civilização moderna" que, de um lado, conduziu à conquista da verdade, abolindo assim os problemas da "barbárie" medieval, mas, de outro, provocou a strage delle illusione, ou seja, a destruição da virtude, da justiça, da glória, do amor e da pátria: base fundamental da moral antiga.

O remédio encontrado pelas outras nações desenvolvidas (França, Alemanha, Inglaterra), para compensar a perda das antigas ilusões foi, como exposto com base no Discorso de 1824, a "sociedade estreita" [società stretta], portanto, "uma vida artificial de relação que reduziu a ética à Galateo" ${ }^{236}$. Aqui se revela igualmente o diagnóstico e a crítica leopardiana a esse trato civil da "aparência" [apparenza] e sua expressão superficial em que predominam

\footnotetext{
${ }^{232}$ Cf. TELLINI, Gino. Leopardi, p. 160.

${ }^{233}$ Cf. TELLINI, Gino. Leopardi, p. 161.

${ }^{234}$ Cf. TELLINI, Gino. Leopardi, p. 161.

${ }^{235}$ Cf. LEOPARDI, Giacomo. Discorso sopra lo stato presente dei costumi degl'italiani, p. 57.

${ }^{236}$ TELLINI, Gino. Leopardi, p. 162: "un'artificiale vita di relazione che ha ridotto l'etica a galateo".
} 
apenas formalidades. Pode-se aqui reenviar a certo fragmento igualmente do Zibaldone, no qual Leopardi comenta certa posição do Galateo:

Se se reformassem o Galateo, as leis, os ensinamentos públicos e privados, a educação das crianças, os livros de moral, os vocabulários [...]. De maneira que aquilo que não é mais necessário, ao contrário, é inútil e prejudicial na essência, não fosse mais necessário nem mesmo na aparência. Assim se tolheria aos homens a necessidade de mentir continuamente, e inutilmente, porque não enganam mais ninguém. $O$ incômodo em que esta [mentira] os coloca muitas vezes; a contradição entre o exterior e o interior; a falsidade [...] se restabeleceria a verdade no mundo; $A$ vida permaneceria nem mais nem menos a mesma como é atualmente, mas apenas eliminada essa linguagem e esses modos de convenção, e esse gênero inconsistente e inútil de bienséances, e de honra, e de deferências a um público que pensa e age como tu mesmo, se eliminariam dos homens muitos aborrecimentos, e esforços e atenções e solicitações vãs, e a vida seria um fato e não uma representação: finalmente concordariam, uma vez juntas, aquelas duas coisas discordantes ab eterno, os ditos e os fatos dos homens $^{237}$.

Se outras nações, em virtude da ignorância delas (Espanha e Russia) permaneciam ainda fundamentos morais, pois não destruídos ainda pelo progresso das Luzes, restava à Itália a posição de menos civil em relação às nações avançadas e mais civil do que estas últimas. Aqui Leopardi recorda a antiga posição ocupada outrora por seu país e a situação, na qual se encontra após a modernização ${ }^{238}$. Esse período da experiência e do pensamento

${ }^{237}$ LEOPARDI, Giacomo. Zibaldone di pensieri, fragmento 664-665, 16.02.1821, in: Leopardi. Tutte le poesie, tutte le prose e lo Zibaldone, pp. 1623-1624: "Si riformassero il Galateo, le leggi, gl'insegnamenti pubblici e privati, l'educazione de' fanciulli, i libri di Morale, i vocabolari [...] In maniera che quello che non è più necessario, anzi è disutile e dannoso in sostanza, non fosse più necessário neanche in apparenza. Così si toglierebbe agli uomini la necessita di mentir sempre, e inutilmente, perchè non ingannano più nessuno; l'imbarazzo in cui questa li pone tante volte; la contraddizione fra l'esteriore, e l'interiore; la falsità [...] si ricondurrebbe la verità nel mondo; la vita resterebbe nè più nè meno la stessa qual è oggidì, ma solamente tolto questo linguaggio e queste maniere di convenzione, e questo genere aéreo ed inutile di bienséances, e di onore, e di riguardi a un pubblico che pensa ed opera come te, si toglierebbero agli uomini molti incomodi, e fatiche, e attenzioni, e sollecitudini [...] Vane; e la vita sarebbe un fatto e non una rappresentazione: finalmente si concorderebbero uma volta insieme quelle due cose discordi ab eterno, i detti e i fatti degli uomini".

238 Tellini comenta, com base no Discorso de 1824, essa mudança que afetou a posição histórico-cultural italiana ante as outras nações. Daí indicar as seguintes oposições: a Itália de outrora "a mais vivaz de todas as nações cultas" [la più vivace di tutte le nazioni colte] tornou-se a mais imoral, "a mais morta" [la più morta], "a mais raciocinadora" [la più ragionatrice], "a mais 
leopardianos, ou seja, aquele relativo ao Discorso de 1824, revela a posição de seu autor ante certa ordem do mundo moderno e a sua recusa de aceitar certo utilitarismo predominante nas práticas civis.

Revela-se aqui a recusa de Leopardi à orientação pragmáticoeconômica do útil, perseguida por Viesseux, que caracteriza a cultura liberal burguesa. Leopardi expressa em sua carta a Giordani, do 29 de julho de 1828, a sua posição ante esse estado de coisas:

Enfim começa a me repugnar o desprezo soberbo que aqui se professa de todo o belo e de toda a literatura: sobretudo porque não me entra mesmo na cabeça que o ápice do saber humano esteja em saber a política e a estatística [...]. [Os indivíduos] são condenados à infelicidade pela natureza e não pelos homens, nem pelo acaso: e para conforto dessa infelicidade inevitável parece-me que valha acima de qualquer coisa os estudos do belo, dos afetos, das imaginações, das ilusões. Desse modo ocorre que o agradável me pareça útil acima de todos os úteis ${ }^{239}$, e a literatura realmente e certamente mais útil do que todas essas disciplinas muito secas; as quais mesmo obtendo a finalidade delas, serviriam muito pouco para a verdadeira felicidade dos homens, que são indivíduos e não povos [...]. De qualquer forma, o privar os homens do agradável nos estudos, parece-me um verdadeiro malefício para o gênero humano ${ }^{240}$.

difícil de ser estimulada pelas coisas ilusórias" [la più difficile ad esser mossa da cose illusorie], a mais insensível à poesia e às "obras da imaginação" [opere d'immaginazione]; (Cf. TELLINI, Gino. Leopardi, p. 162.

${ }^{239}$ Grifo nosso. Com esse grifo pretende-se aqui destacar a diferença entre aquilo que Leopardi compreende como utilidade e aquilo que ele refuta no âmbito de uma orientação pragmáticoliberal, ou seja, que caracteriza a prática no mundo do cálculo moderno. Trata-se aqui de uma noção sua que se opõe justamente ao utilitarismo da cultura oficial. Por conseguinte, o útil defendido por Leopardi faz apelo a dimensões poéticas, a saber, sensística, estética e afetiva, porém, não de forma estetizada, mistificante ou espiritualista (Ver, nesse sentido, as observações apresentadas por Tellini. Cf. TELLINI, Gino. Leopardi, pp. 161-162.

${ }^{240}$ LEOPARDI, Giacomo. Epistolario, in: Leopardi. Tutte le poesie, tutte le prose e lo Zibaldone, Roma: Newton\&Compton, 2010, p. 1370: "In fine mi comincia a stomacare il soperbo disprezzo che qui si professa di ogni bello e di ogni letteratura: massimamente che non mi entra poi nel cervello che la sommità del sapere umano stia nel saper la política e la statistica [...] sono condannati alla infelicità dalla natura, e non dagli uomini né dal caso: e per conforto di questa infelicità inevitabile mi pare che vagliano sopra ogni cosa gli studi del bello, gli afetti, le immagionazioni, le illusioni. Così avviene che il dilettevole mi pare utile sopra tutti gli utili, e la letteratura utile più veramente e certamente di tutte queste discipline secchissime; le quali anche ottenendo i loro fini, gioverebbero pochissimo alla felicita vera degli uomini, che sono individui e non popoli [...] In ogni modo, il privare gli uomini del dilettevole negli studi, mi pare che sia un vero malefizio al genere umano". 
Aqui se revela, sem dúvida uma concepção distinta do útil em Leopardi, que não se identifica com aquela do projeto de Viesseux: algo que explica novamente a sua recusa de aceitar o seu convite de "colaborador regular" [collaboratore regulare] ${ }^{241}$ da Antologia. Disso resulta igualmente a sua ironia, ao escrever: "sinto vontade de rir desse furor de cálculos e dessas divagações políticas e legislativas" [mi viene un poco da ridere di questo furore di calcoli e di arzigogoli politici e legislativi] ${ }^{242}$.

Certamente Leopardi se vê envolvido no drama histórico de seu presente - como revelam não só o Discorso sopra lo stato presente dei costumi degl'italiani, mas também obras como as Operette morali e outras, sem esquecer aqui do Zibaldone di pensieri. Nessas obras, portanto, se articulam, ao mesmo tempo, "um trabalho mais impessoal da mente" [lavoro più impersonale della mente] $]^{243}$ e elementos da sua experiência civil: algo que distingue igualmente a sua filosofia social. Ademais, alguns conceitos apresentados por Leopardi, ao longo de seus escritos, revelam também a sua compreensão, seja da realidade moderna seja da filosofia moderna ${ }^{244}$ desse período. Cumpri-se aqui a exigência de se abordar essa relação no decorrer da exposição desta tese, em que se articulam um Leopardi "filósofo da sociedade" e um Leopardi "metafísico", ou seja, um apenas? ${ }^{245}$

241 Cf. LEOPARDI, Giacomo. Epistolario, in: Leopardi. Tutte le poesie, tutte le prose e lo Zibaldone, pp. 1310-1311.

${ }^{242}$ Cf. LEOPARDI, Giacomo. Epistolario, in: Leopardi. Tutte le poesie, tutte le prose e 10 Zibaldone, p. 1370. Convém aqui destacar, a reflexão de Gaspare Polizzi acerca da abordagem leopardiana em relação à razão científica e à filosofia moderna, a qual ressalta algumas questões concernentes ao saber e à vida civil. Nessa exposição de Polizzi, pode-se identificar, ao mesmo tempo, uma reflexão de Leopardi sobre a "sabedoria antiga" e os problemas relativos à crise da racionalidade moderna. Segundo Polizzi, "Leopardi vê na sabedoria antiga uma possível solução, com o tom sempre, de qualquer modo, racional, para sair da crise da racionalidade moderna. Se não se pode 'geometrizar toda a vida', na medida em que tal procedimento é contrário à natureza do homem e do mundo" (Cf. POLIZZI, Gaspare. Leopardi e "le ragioni della verità". Scienze e filosofia della natura negli scritti leopardiani, pp. 61-67).

${ }^{243}$ Ver nesse sentido as considerações de FERRUCCI, Carlo. Leopadi filosofo e le ragioni della poesia, pp. 100-101.

${ }^{244}$ Ver, nesse sentido, SANSONE, Mario. Storicità e letteratura: da Machiavelli a Leopardi. Napoli: Edizioni Scientifiche Italiane, 1997, pp. 205-260.

${ }^{245}$ Em Magis Amicus Leopardi, Cacciari, valendo-se da orientação de um dos fragmentos da obra Nachgelassene Fragmente (1875-1879), de Nietzsche, em que seu autor diz suportar apenas aqueles poetas que têm também pensamentos, como Pindaro e Leopardi, apresenta uma interpretação dos Canti leopardianos. Em sua interpretação Cacciari sustenta: "[...] a terra das verídicas sensações, a terra onde 'a verdade' não pode abstrair-se da percepção sensível. É a terra do 'verdadeiro filósofo' leopardiano" [la terra delle veridiche sensazioni, la terra dove la 


\title{
CAPÍTULO II
}

\section{Civilização meridional e meridionalidade: a problemática leopardiana entre antigos e modernos}

\author{
Sebbene l'antichità era il tempo del bello, e \\ della immaginazione, tuttavia anche allora la \\ Grecia e l'Italia ne erano la patria, e luogo \\ [...] Così per lo contrario, sebbene l'età \\ moderna è il tempo del pensiero, nondimeno \\ il settentrione ne è la patria.
}

Giacomo Leopardi, Zibaldone di pensieri

\begin{abstract}
A reflexão leopardiana sobre a modernização europeia tem a sua continuidade no Discorso de 1824 com a problemática concernente à relação entre "povos meridionais" [popoli meridionali] e "povos setentrionais" [popoli settentrionali], uma vez que Leopardi reflete ainda sobre a "destruição das ilusões" [strage delle illusioni], pertencente ao ethos antigo ${ }^{246}$, ocorrida no
\end{abstract}

"verità" non pùo astrarsi dalla percezione sensibile. Ė la terra del "vero filosofo" leopardiano]; (Cf. CACCIARI, Massimo. Magis Amicus Leopardi. Due saggi. Caserta: Saletta del'Uva, 2005, p. 49). Sobre os fragmentos póstumos de Nietzsche acerca de Leopardi, ver NIETZSCHE, Friedrich. Intorno a Leopardi. OTTO, Walter F. Leopardi e Nietzsche [1937], a cura di Cesare Galimberti. Genova: II Melangolo, 2000. Para Porena, o verdadeiro Leopardi, como pensador, permanece até o final do Zibadone, das Operette morali e de quase todas as líricas. Em seguida, Porena se propõe a avaliar, de forma breve e sintética, o que ele denomina de doutrinas leopardianas, pois não identifica nelas um todo absolutamente uno e coerente, mas a presença de vários estados, de vários ramos dessas doutrinas. Ademais, ele reconhece não serem perfeitamente conciliáveis, pois se revela em cada uma delas aspectos de pensamento longamente meditado e profundamente sentido. Daí ele resumir o pensamento pessimista de Leopardi em três pontos principais: "o sistema do pessimismo histórico e social, que considera a Natureza como provedora benéfica de ilusões, e põe as raízes da dor nos progressos da razão e da experiência, no contrato social com os homens, a partir do qual aquelas ilusões são destruídas; o sistema do pessimismo natural, que faz a natureza inimiga do homem e não rejeitando quanto ao resto o primeiro sistema, dirige a atenção, sobretudo, para dores materiais, as quais o homem está submetido, à sua pequenez no universo, à sua finitude, à sua transitoriedade, à terrível necessidade da morte; a teoria do prazer, que põe a impossibilidade do prazer no mecanismo íntimo psicológico do homem, e se mantém na mente de Leopardi tanto ao lado do pessimismo natural como do social" (Cf. PORENA, Manfredi. Scritti leopardiani [1923], p. 178).

${ }^{246}$ Deve-se aqui destacar as considerações de Mario Andrea Rigoni que defende um pensamento "impolítico" [impolitico] ou "antipolítico" [antipolitico] em estrita dependência de uma "visão antihistórica" [visione antistorica]. Isso significa que Leopardi, embora não fosse atraído pela política e pela história, as quais ocupam um lugar relevante no seu Zibaldone e em outras obras, não podia novamente pôr nenhuma esperança senão naquela submersa com 0 mundo antigo: o seu supremo ideal tanto nesse como em qualquer outro âmbito. Leopardi reconhecia nas repúblicas antigas aquele momento irrepetível no qual individualidade e socialidade, bem próprio e bem comum, atividade política e criação estética, longe de se 
mundo moderno, e o advento nesse mundo de outros "fundamentos da moral" [fondamenti della morale]. É preciso explicitar, neste momento, como a nova civilização busca reparar os danos causados por essa "destruição", ou seja, o vazio deixado pelo desaparecimento do ethos anterior. Leopardi apresenta, em tal contexto de sua reflexão, o tema da relação entre antigos e modernos, que agora orienta a sua abordagem sobre a relação entre meridionais e setentrionais no domínio da problemática moderna. Essa abordagem se apresenta, quer no Discorso de 1824 quer em alguns fragmentos do Zibaldone di pensieri. Considerar a relação entre meridionais e setentrionais possibilita um aprofundamento da diagnose leopardiana do presente, na medida em que se torna necessário expor outros elementos que configuram, tanto no sentido antropológico-cultural quanto no sentido filosófico-civil, o mundo moderno.

\subsection{O Mezzogiorno como universo cultural: a Itália e a sua recepção} europeia

Na fortuna critica leopardiana se reconhece Leopardi como o primeiro a apresentar "uma ideia muito particular e original" [un idea particolarissima e originalissima $^{247}$ do meridionale e de havê-la analisada durante longo tempo em seus escritos, em especial, no Zibaldone ${ }^{248}$. Contudo, as suas análises não

excluírem reciprocamente, viviam em um acordo milagroso. Após o ocaso dessa realidade, que assume as cores do mito, o mundo termina em convulsões insensatas e contradições insolúveis. Ver, nesse sentido, RIGONI, Mario Andrea. Introduzione, in: LEOPARDI, Giacomo. La strage delle illusioni: pensiero sulla politica e sulla civiltà, Milano: Adelphi, 1993 (2ªed.), pp. 30-31. Já Fabio Vander defende um Leopardi sistemático e conscientemente contrário à ideologia da "classe política", reconhecendo-o como o único capaz de uma autêntica doutrina democrática. Segundo Vander, o "estado democrático" seria para Leopardi o único no qual não haveria nem excesso de realismo nem de utopismo, nem autoritarismo nem demagogia, mas um bom equilíbrio entre os termos. Ademais, nenhuma classe política pode pretender incarnar o poder por direito divino, social, cultural ou outro, pois limitado pela presença de outros poderes concorrentes e, de qualquer modo, controlado, exercitado coram populo. Daí porque se é "sociedade" não pode ser "estreita", assim se é "classe", não pode ser "política": a política é da polis, não de uma classe (Cf. VANDER, Fabio. De philosophia italica. Modernità e politica in Vico e Cuoco. Lecce: Pensa Multimedia, 2010, pp. 12-15).

${ }^{247}$ Cf. PLACANICA, Augusto. Leopardi e il Mezzogiorno del mondo, p. 9.

248 Nesse seu escrito Placanica, reportando-se ao tema do meridione na obra leopardiana, defende haver uma diferença de abordagem entre a forma assumida por Leopardi no Discorso sopra lo stato presente dei costumi degl'italiani, de 1824 , daquela desenvolvida no Zibaldone di pensieri: por conseguinte, duas perspectivas distintas de abordagem. Isso porque, no Discorso há um empenho de Leopardi em indagar aqueles defeitos e atrasos da sociedade italiana, que será, após a revisitação do meridião leopardiano, o tema do Discorso. Já aquela 
teriam sido acolhidas, pois não constituiria na posteridade qualquer herança, pois essa ideia, "tipicamente sua desapareceu do horizonte da crítica leopardiana" [tipicamente sua è sparita dall'orizzonte della critica

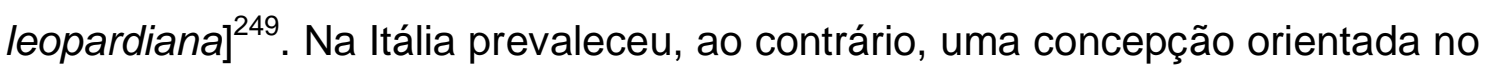
sentido sociopolítico, uma vez que se compreendeu, em particular, o Mezzogiorno ${ }^{250}$ histórico italiano, enfatisado, sobretudo, a partir dos inícios da Modernidade ${ }^{251}$.

Se a problemática do Mezzogiorno é um tema leopardiano, conforme alguns intérpretes ${ }^{252}$, distinto das abordagens assumidas na Modernidade, a

crítica leopardiana à Itália, do início do século XIX, apresenta uma novidade, ou seja, "um parêntese originalíssimo" decorrente de um quadro bem mais vasto de sólidas convicções acerca do meridione, constituindo assim um continuum no interior do corpo do Zibaldone, no qual uma identificação absolutamente diferente, absolutamente ideologizada e mitificada, nos oferece um Meridione do mundo bem antes da Europa e da Itália, assumindo proporções e latitudes novas, absolutamente inéditas (Cf. PLACANICA, Augusto. Leopardi e il mezzogiorno del mondo, pp. 48-49).

${ }^{249}$ Cf. PLACANICA, Augusto. Leopardi e il Mezzogiorno del mondo, p. 9.

250 Para Placanica e Lucio Felici, Leopardi jamais usou o termo meridione nas suas formulações, mas adotou exclusivamente o étimo "meridional". Contudo, Placanica compreende com o termo meridione, reenviando a Leopardi daquele momento, a extensão de tal conceito ao mundo habitado pelos homens no antigo oriente e no antigo mediterrâneo, ao passo que usará aquele de Mezzogiorno para se reportar ao Sul em geral e, sobretudo, ao Mezzogiorno da Itália. Ver aqui: PLACANICA, Augusto. Leopardi e il Mezzogiorno del mondo, p. 20; Já Felici justifica a não existência do substantivo meridione em Leopardi com base em uma tradição linguística literária que refulta meridione, enquanto substantivo derivado do adjetivo meridional, com base no modelo de setentrione, que tem por sua vez uma formação autônoma. Ver, nesse sentido, FELICl, Lucio. Meridionali, meridionalità, meriggio. In: Lo Zibaldone cento anni dopo. Composizione, edizioni, temi. Atti del X Convegno internazionale di studi leopardiani, vol. II, set/1998, Recanati-Italia, Centro Nazionale di studi leopardiani (CNSL), Firenze: OLSCHKI Editore, 2001, p. 682.

${ }^{251}$ Cf. PLACANICA, Augusto. Leopardi e il Mezzogiorno del mondo, p. 9.

${ }^{252}$ Franco Cassano, embora não mencione Placanica em suas análises, publicadas cinco anos depois, também defende ser relevante para a compreensão do pensamento de Leopardi a distinção entre Meridionais e Setentrionais. Segundo Cassano, o silêncio dos críticos em relação a tal tema ocorreu em função de uma "afetuosa cumplicidade" [affettuosa complicità] relativa ao poeta, com o intuito de desculpá-lo ante um argumento tão controverso atualmente: fruto de um "materialismo ingênuo e naturalista, incapaz de reconhecer o peso da história e a capacidade das sociedades, [...] de transformar o ambiente que as circunda" [materialismo ingenuo e naturalístico, ancora incapace di riconoscere il peso della storia e la capacita delle società [...] di trasformare l'ambiente che le circonda]. Daí as referências "naturais ou geográficas" [naturali o geografiche] utilizadas por Leopardi parecerem "obsoletas" [obsolet], "politicamente incorretas" [politicamente scorretti] e "cientificamente superadas" [scientificamente superat], contrapostas a uma difusa ideia de "progresso" presente nas ciências sociais. Conforme Cassano é preciso, entretanto, em contraste com a falta de atenção e "presunção" [sufficienza] dos críticos da obra leopardiana, uma orientação crítica que considere as perspectivas cognitivas da distinção, espacial e geográfica, entre Meridionais e Setentrionais, na medida em que foram, de um lado, apagadas e, de outro, reduzidas a simples expressões daquelas temporais, a graus diversos do desenvolvimento histórico (Cf. 
sua visão apresenta uma característica particular, mas antes de abordá-la é preciso tecer algumas considerações acerca de seu sentido geral, uma vez que o Discorso de 1824 e o Zibaldone di pensieri revelam uma maior profundidade e complexidade na visão que apresentam do meridionale, pois nela se entrelaçam elementos de norte e sul; antigo e moderno; civilização; cultura e mundos: algo que não se esgota em uma simples análise sociopolítica, tipicamente positivista, carente de toda compreensão de outros elementos constituidores do novo mundo e daqueles destruídos do antigo ethos.

O Mezzogiorno, como universo cultural, não é um conceito recente, "no sentido mais profundo e radicado e quase físico do termo, é conceito tanto mais antigo e compreensivo quanto mais se introduz na ótica da acepção estritamente leopardiana" ${ }^{253}$. A percepção do Mezzogiorno europeu é algo que veio a se estabelecer na consciência dos doutos da Europa entre o século XVII e o XVIII. Nesse sentido, a Itália foi acolhida, em especial, como "realidade diferente e interessante, amável justamente por sua diversidade: como se aquele mezzogiorno e aquela Itália fossem ainda mergulhados no antigo" 254 .

Não se trata aqui, porém, do "antigo" compreendido naquela Idade Média, interpretada pelos renascentistas e identificada como momento de "trevas": um passado que devesse ser esquecido ${ }^{255}$. O antigo, portanto, é

CASSANO, Franco. Oltre il nulla. Studio su Giacomo Leopardi. Roma-Bari: Laterza\&Figli, 2003, pp.3-5.

${ }^{253}$ PLACANICA, Augusto. Leopardi e il Mezzogiorno del mondo, p. 20: "nel senso più profondo e radicato e quase físico del termine, è concetto tanto più ântico e comprensivo quanto più si rientra nell'ottica dell'accezione strettamente leopardiana".

${ }^{254}$ PLACANICA, Augusto. Leopardi e il Mezzogiorno del mondo, p. 21: "realtà diversa, e interessante e amabile próprio per questa sua diversità: come se quel Mezzogiorno e quell"Italia fossero ancora affondati nell'antico".

${ }^{255}$ Conforme Antonio Viscardi, Condorcet é um dos que contribuiu para definir a noção iluminista do Medievo como noite tenebrosa e profunda, e usa o termo renaître para indicar o processo por meio do qual o espírito humano encontra, em certo momento, a via do "progresso" que havia perdido. O renaître de Condorcet se relaciona exatamente com o risorgimento de Bettinelli que, em 1773, publicou o célebre ensaio Del risorgimento d'Italia negli studi, nelle arti, nei costumi, dopo il Mille, em que afirma: "para bem conhecer aquela Itália que nós começamos a ver seputada nas barbáries e, em seguida, renascer a nova cultura e beleza (Cf. VISCARDI, Antonio. Storia della letteratura italiana: dalle origini al Rinascimento. Milano: Nuova Accademia, 1960, p. 466. Deve-se destacar ainda os argumentos de Kristeller e Garin em relação a essa cisão radical entre Medievo e Renascimento, indicando certa escola classicista medieval. Ver aqui KRISTELLER, Paul. Tradição clássica e pensamento do Renascimento [1954]. Trad. port. Artur Mourão, Lisboa: Edições 70, 1995, pp. 11-29;

II pensiero e le arti nel Rinascimento [1954]. Trad. it. Maria Baiocchi, Roma: Donzelli editore, 2005 (2ª ed.), pp. 3-22; GARIN, Eugénio. Idade média e Renascimento [1973]. Trad. port. 
aquele correspondente ao "mítico mundo clássico (grego e latino)". Esse mundo se apresentava à recepção moderna por meio de "personagens", "ruínas", "poesia" e "paixões" de uma idade desaparecida.

Se durante séculos privilegiou-se uma "imagem da Itália" valendo-se da antiga Roma, em seguida, no século XVI outra imagem vem edificada mediante o Renascimento. Daí a Itália parecer

ainda mais bela e digna de veneração, segundo uma mitologia que remontava aos exórdios da [...] literatura, de Dante e de Petrarca: merecidamente os faustos e a cultura da Roma moderna ressoavam as grandezas da Roma dos Césares: mas, junto com Roma, agora também as outras capitais italianas pareciam ser faróis de uma civilização renovada: a Nápoles aragonesa, a Milão viscontea e esforsesca, a Veneza dominadora dos mares, e as tantas cidades intermediárias centrosetentrionais transbordante de estupendas obras de $\operatorname{arte}^{256}$.

O mesmo não ocorria, porém, com as outras cidades italianas, uma vez que não se destacavam no pensamento do europeu dotado de certa cultura.

Não obstante o processo de modernização e, nesse processo, a conquista de uma "identidade específica" por parte de cada nação ${ }^{257}$, a ideia da Itália coincidia ainda com a "imagem da Roma antiquíssima". Trata-se de uma

Isabel Teresa Santos et al., Lisboa: Editorial Estampa, 1994, pp. 21-61; del Rinascimento. Profilo storico. Roma-Bari: Laterza\&Figli, 2010, pp. 5-34. La cultura

${ }^{256}$ PLACANICA, Augusto. Leopardi e il Mezzogiorno del mondo, pp. 21-22: "ancor più bella e degna di venerazione, secondo una mitografia che risaliva agli esordi della [...] letteratura, di Dante e di Petrarca: meritatamente i fasti e la cultura della Roma moderna riecheggiavano le grandezza della Roma dei Cesari: ma, insieme con Roma, adesso anche le altre capitali italiane sembravano esser fari di una rinnovata civiltà: la Napoli aragonese, la Milano viscontea e sforzesca, la Venezia dominatrice dei mari, e le tante città intermedie centrosettentrionali trabocanti di stupende opere d'arte". Sobre os exórdios da literatura e a relação entre Dante e Petrarca, ver VISCARDI, Antonio. Storia della letteratura italiana: dalle origini al Rinascimento, pp. 267-397; PONSETTO, Antonio. L'umanesimo Rinascimentale e la nascita della Modernità. Tra autonomia dell'uomo, nuove forme di dominio e loro superamento. Padova: Università di Padova, 2011, pp. 15-66; CAPPELLI, G uido. L'umanesimo italiano da Petrarca a Valla. Roma: Carocci, 2007, pp. 31-54. Sobre a imagem de cidade e sua grandeza, ver aqui aquela de uma Napoli gentile, em que a autora descreve desde os aspectos geográficos e climáticos aos aspectos culturais, ver aqui DE RUGGIERO, Maria Grazia. La Napoli Gentile di Giambattista Vico: curiosità, storie e suggestioni. Napoli: Grimaldi, 2008, pp. 9-38.

257 É relevante destacar nesse momento, o estudo de Federico Chabod relativo a construção do sentido de "nação" na modernidade e os elementos que nessa construção, segundo a orientação dos autores, foram relevantes, desde o ambiente geográfico e climático, com aqueles físicos, mas também as forças morais, educação, a vida política, a tradição. Destaca-se também na análise do autor a presença das reflexões de Leopardi contidas, em particular, no Zibaldone di pensieri (Cf. CHABOD, Federico. L'idea di nazione. Roma-Bari: Laterza, 2010 (17ª ed.), pp. 131-134). 
Roma herderia de etruscos e gregos, pois, muito tempo antes de Cristo, já havia ampliado o seu domínio militar e cultural sobre a Europa, a Ásia e a África. Nessa ampliação havia deixado muitos sinais e vestígios imperecíveis de sua grandeza ${ }^{258}$.

$\mathrm{Na}$ Europa desses séculos, a Roma com a qual a Itália era identificada pelos doutos era tida como unicum na história. Era apenas essa Roma, com os seus mil anos de "triunfos e ruínas", deixados ao longo de seu percurso histórico, que permanecia sempre o "centro ideal do mundo", como algo ininterrupto. Desde a divergência entre Rômulo e Ciprião, de César ao Império, de Constantino até os saques de Genserico, de Alarico e os domínios germânicos, por sua vez, imagens sujeitas à mensagem de Galileu, permanecia sempre, entre os doutos, aquela do vigário empossado em Roma ${ }^{259}$, ou seja, de Roma invocada como dimensão sagrada.

Com o tempo, após certos acontecimentos que marcaram o declínio da potência hegemônica romana, desaparece cada vez mais o predomínio da visão da antiga Roma e se destaca aquela, durante a Idade Média, de uma Roma

como dimensão sagrada, e a Itália permanecia sede natural daquele antigo secreto poder. No estabelecimento daquele papado 'pelo qual Cristo é romano' prosseguia e afirmava a grandeza jamais sepultada da Cidade eterna (...). Roma - estrela sem declínio - permanecia, na Europa, a única constante luz ideal em um instável firmamento de estados que conduziam uma vida sujeita àquelas alternâncias inexoráveis que, desde os reis babilônicos aos faraós, desde polis a Urbe, haviam arrastado impérios, reis, dinastias ${ }^{260}$.

\footnotetext{
${ }^{258}$ Cf. PLACANICA, Augusto. Leopardi e il Mezzogiorno del mondo, p.22.

259 PLACANICA, Augusto. Leopardi e il Mezzogiorno del mondo, p. 22.
}

260 PLACANICA, Augusto. Leopardi e il Mezzogiorno del mondo, pp. 22-23: "come dimensione sacrale invocata, e l'Italia restava sede naturale di quell'antico potore. L'insediamento di quel papato 'per cui Cristo è romano' proseguitava e inverava l'ormai sepolta grandezza della Città eterna [...]. Roma - stella senza tramonti - restava, in Europa, l'única costante luce ideale in un sempre cangiante firmamento di stati che conducevano una vita soggetta a quelle inesorabili alternanze che, daí re babilonesi ai faraoni, dalle pòleis all'Urbe, avevano travolto imperi, re, dinastie". 
É justamente no Renascimento que ocorre uma mudança na visão europeia da Itália: período de renovação cultural ${ }^{261}$. Não obstante a defesa da vida civil e o tom moral ${ }^{262}$ intenso nesse período, algo deixava o estrangeiro "atônito" ante uma "civilização de uma Itália para cuja conquista, impelido por um mito inveterado, ali se atormentava tanto e tão injustamente". Surpreendia, quer aos italianos quer aos estrangeiros, "o caráter covarde de toda a sociedade italiana" ${ }^{263}$ e a ausência completa, nessa sociedade, de "espírito público" diante dos conflitos políticos que nela se apresentavam ${ }^{264}$.

Tratava-se de uma pátria destituída de disposição para se rebelar contra as várias investidas estrangeiras. Daí florecer, a partir do século XVI, críticas exasperadas à Itália, pois desde aquela época, e na continuidade, teria permeado a aventura intelectual de muitos italianos e europeus, uma vez que levados a acreditar, com frequência, que os italianos e os meridionais, de modo geral, tivessem sido abituados à dissipação dos talentos e da melhor energia deles, não pela história, mas por uma "natureza fácil e doce". Em seguida, não

261 Sobre a renovatio cultural, ver as considerações sobre os studia umanitatis presentes nos ensaios organizados por KRAYE, Jill. Introducción al humanismo renacentista [1998]. trad. esp. Carlos Clavería, España: Cambridge University (Sucursal en España), 1998.

${ }^{262}$ Merece destaque nessas questões relativas à vida civil e o tom moral no período renascentista, o surgimento de uma literatura voltada para o trato civil e a convivência, identificado pelos estudiosos com a designação de trattatistica sul comportamento ou literatura das manière. Essa literatura tem como fonte as obras de Aristóteles (Ética a Nicômaco; Econômicos; Política e Retórica) e as de Cícero (Dos deveres, Do orador). Ademais, foi II libro del cortegiano que serviu de modelo às demais, com base na ideia de forma del vivere. Nesse sentido, ver os estudos organizados por Marc Fumaroli que abordam essa literatura (Cf. PONS, Alain. La rhétorique des manière au XVIe siécle em Italie. In: FUMAROLI, Marc (org.). Histoire de la rhétorique dans l'Europe moderne: 1450-1950. Paris: Presses Universtaire de France, 1999, pp. 411-429. Sobre os autores dessa trattatistica ver nota 69 do primeiro capítulo desta Tese.

${ }^{263}$ Cf. PLACANICA, Augusto. Leopardi e il Mezzogiorno del mondo, p. 23.

${ }^{264}$ Sobre essa situação da sociedade italiana no período considerado, não obstante a defesa da vida civil e o tom moral de certa trattatistica, ver LARIVAILLE, Paul. A Itália no tempo de Maquiavel. Trad. br. Jonatas Batista Neto. São Paulo: Companhia das Letras, 1988, pp. 9134; CANFORA, Davide. Prima di Machiavelli. Politica e cultura in età umanistica. Roma-Bari: Laterza\&Figli, 2005, pp. 5-79; JACOBELLI, Jader. Machiavelli e/o Guicciardini. Alle redici del realismo politico. Milano: Mursia, 1998, pp. 16-115; GARIN, Eugenio. Machiavelli fra politica e storia. Torino: Einaudi, 1993, pp. 3-61. SASSO, Gennaro. Niccolò Machiavelli. II pensiero politico. vol. I, Bologna: II Mulino, 1992, pp. 481-581. CHABOD, Federico. Scritti su Machiavelli. Torino: Einaudi, 1964, pp. 40-55; GILBERT, Felix. Machiavelli e Guicciardini. Pensiero politico e storiografia a Firenze nel Cinquecento [1965]. Trad. it. Franco Salvatorelli, Torino: Einaudi, 1970, pp.17-94. 
só os italianos, mas em geral todo aquele povo sobre o qual pesasse uma "natureza propícia", ou seja, precisamente todo o Mezzogiorno ${ }^{265}$.

É, portanto, com o advento do Renascimento que, em tal época, aquela Roma perde aos poucos o primado que a idealizava e toda credibilidade moral e cultural. Nesse sentido ocorre uma mudança na recepção do forasteiro ante a Itália, pois no final do século XVI,

para um viajante excepcional como Michel de Montaigne, as ruínas e as grandezas do passado, sobretudo em Roma, demonstravam pouca coisa ante as divertidas curiosidades que a cidade oferecia, começando pelos ritos pontifícios solenes; e mais entusiasmos ele obtinha das cenas campestres da Toscana, com pastores e pastorinhas que recitavam Ariosto $^{266}$.

Vinculava-se, com efeito, o último indício de certa civilização, ou seja, Roma, Itália e Mezzogiorno da Europa. Ademais, revelava-se, desde já há algum tempo, certa decadência no que concerne à "concretude das vicissitudes humanas" [concretezza delle vicende umane] ${ }^{267}$. Por conseguinte, entre o século XVI e XVII, ocorre, diz Placanica, que:

no quadro de um Ocidente burguês impulsionado pela conquista do mundo, o Mezzogiorno da Europa semelhante a uma noite se dissipando à luz da aurora - foi-se distanciando do proscênio daquela história que procedia a passos velozes em direção a um futuro de mil promessas: uma história da qual a ideia de progresso agora constituía a nova fée ${ }^{68}$.

${ }^{265}$ Cf. PLACANICA, Augusto. Leopardi e il Mezzogiorno del mondo, p. 24.

266 Ibidem: "per un viaggiatore d'eccezione come Michel de Montaigne, i ruderi e le grandezze del passato, soprattutto a Roma, risultavano poca cosa di fronte alle divertenti curiosità che la città offriva, a cominciare daí solenni riti pontifici; e più entusiasmo egli traeva dalle scene campestri di Toscana, com pastori e pastorelle che recitavano l'Ariosto". Ver nesse sentido DE MONTAIGNE, Michel. Viaggio in Italia [1774]. Trad. it. Ettore Camesasca. Milano: BUR-Rizzoli, 2010 (3e․), pp. 232-252. Em Corinne, Madame de Staël afirma que a verdadeira característica da alegria italiana "não é a sátira, mas a imaginação; não a representação dos costumes, mas os exageros poéticos. É Ariosto, não Molière, que divertia os italianos" (Cf. De Staël, Madame. Corinne o L'Italia, Milano: Mondadori, 2010, p. 174).

${ }^{267}$ Cf. PLACANICA, Augusto. Leopardi e il Mezzogiorno del mondo, p. 24.

${ }^{268}$ PLACANICA, Augusto. Leopardi e il Mezzogiorno del mondo, pp. 24-25: "nel quadro di un Occidente borghese spinto alla conquista del mondo, il Mezzogiorno d'Europa - simile a una notte dileguantesi alle luci dell'alba - si ando allontanando dal proscenio di quella storia che procedeva a passi veloci verso un futuro dalle Mille promesse: una storia di cui l'idea di progresso costituiva adesso la nuova fede". Sobre a ideia de um pensamento meridiano devese destacar a reflexão de Cassano em seu livro II pensiero meridiano, de 1996, em que ele 
Isso revela então como o Mezzogiorno e, em particular, a Itália se tornam, com efeito, "protagonistas" [protagonisti] e "símbolos" [simboli] de um mundo em decadência. Daí ocorrer uma mudança na "consciência europeia" em relação a ambos, pois começa a se sentir enamorada por uma "atmosfera desvanecida" para sempre, ou seja, de um sol e de um céu que davam aparência de pertencer, de modo exclusivo, àquelas terras mediterrâneas, já tão distantes de suas glórias passadas, mas ainda tão florescentes e ricas de tantas "veneráveis memórias"269.

É justamente em pleno século XVIII que o chamado Grand Tour tende a completar a sua função formativa em tal Mezzogiorno, interpretado na sua forma residual, misto de realidade e de nostalgia, de uma sociedade que chegou definitivamente ao seu declínio. Ademais, o século XVIII tardio, na sua expressão racionalista e iluminista, revelava, por sua vez, certa oscilação: de um lado a completa rejeição à Idade Média e, de outro, uma nova visita àquele mundo repleto de ingenuidade e espontaneidade ${ }^{270}$. Daí tal herança se apresentar

já madura em Rousseau, teria passado nos personagens apaixonados de outros dois típicos expoentes da alta Europa, ao mesmo tempo, moderna e propensa à nostalgia romântica, eles também preferidos por Leopardi, isto é, Madame de Staël e Lord Byron. [...] E Madame de Staël, sobretudo com Corinne ou de l'Italie [...] foi máxima inspiradora deste último [de Leopardi], propenso [...] a analisar não apenas a Itália mas todo o Mezzogiorno, o "seu" meridione, à presença vigilante das categorias de Madame, última herdeira muito aclamada do Grand Tour ${ }^{271}$.

reinvidica uma grande autonomia e especificidade do Mezzogiorno valendo-se de uma inteligência geopolítica. A sua proposta de um pensamento meridiano não se esgota, todavia, na defesa do pluralismo e da multiplicidade das perspectivas contra a expansão imperial de uma única cultura (Cf. CASSANO, Franco. I/ pensiero meridiano. Roma-Bari: Laterza, 2011 (4ª ed.), pp. VI-XIV; XVIII-XXVIII-XXXIV.

${ }^{269}$ Cf. PLACANICA, Augusto. Leopardi e il Mezzogiorno del mondo, p. 25.
${ }^{270}$ Cf. PLACANICA, Augusto. Leopardi e il Mezzogiorno del mondo, p. 25.
${ }^{271}$ PLACANICA, Augusto. Leopardi e il Mezzogiorno del mondo, pp. 25-26: "già matura in Rousseau, sarebbe passata negli appassionati personaggi di altri due tipici esponenti dell'alta Europa, al contempo moderna e incline alla nostalgia romântica, anch'essi prediletti da Leopardi, cioè Madame de Staël e Lord Byron. [...] E Madame de Staël soprattutto, con Corinne ou de l'Italie [...] fu inspiratrice massima di quest'ultimo, teso, [...] ad analizzare non solo l'Italia 
Para uma compreensão dos motivos responsáveis por tal mudança na recepção e concepção modernas do Mezzogiorno e da Itália, que de protagonistas da história se tornaram apenas uma simples periferia dos países desenvolvidos $^{272}$, pode-se aqui sustentar então:

após a descoberta da América, décadas após décadas, a Europa mediterrânea - que com a Espanha [...] havia [...] definitivamente perdido a sua antiga primazia, em proveito das sociedades ocidentais do norte, ou melhor, das novas linhas de tráfico no Atlântico, que, na perspectiva de um processo furioso de modernização, haviam deslocado os eixos da economia no mundo, fazendo daquele antigo mar interno, que havia sido o mediterrâneo, um universo secundário e quase esquecido (e Lepanto, em 1571,

ma l'intero Mezzogiorno, il 'suo' meridione, alla vigile presenza delle categorie di Madama, ultima acclamatissima erede del Grand Tour. Andrea Rigoni comenta sobre a vasta literatura estrangeira, sobretudo, francesa e inglesa, fruto do Tour tradicional na Itália, quase obrigatório para as classes intelectuais europeias entre os séculos XVIII-XIX, a qual tinha a sua remota origem no Journal de Voyage en Italie de Montaigne (Cf. RIGONI, Mario Andrea. Leopardi e $i$ costumi degli italiani, p. 7). Sobre esse argumento, ver ainda CASSANO, Franco. Oltre il nulla. Studio su Giacomo Leopardi, p. 4. Entre os autores que se incluem nesses diários de viagem pode-se destacar também o escrito de Montesquieu, no qual declara o seu amor por Roma: "la plus belle ville du monde". Destaca-se ainda nesse escrito a sua experiência napolitana, em que indica o nome de Giannone entre os representantes da cultura de Nápoles. Em Veneza havia anotado, por sugestão de Antonio Conti, de comprar, ao chegar a Nápoles, os Principii di una nuova scienza de Giambattista Vico (Cf. Montesquieu. Viaggio in Italia. Trad. it. Massimo Colessanti, Roma-Bari: Laterza, 2008 (2 $2^{\mathrm{a}}$ ed.), pp. 147-206). Em relação aos costumes e ao caráter dos italianos destaca-se, sobretudo, a afirmação: a "ausência de sociedade civil e de opinião pública é a causa, mas, não obstante tudo aquilo que se diz da perfídia dos italianos, estou convencida que seja um dos países no mundo com mais bondade" (Cf. DE STAËL, Madame. Corinna o L'Italia [1807]. Milano: Mondadori, 2010 (4를. comenta que o pensamento do Zibaldone, de 1820, nos revela uma leitura penetrante e profunda, um conhecimento já amplo da obra de Madame de Staël. Ravasi assegura que a essa data Leopardi havia lido também os mais célebres escritos literários e filosóficos de Staël (Cf. RAVASI, Sofia. Leopardi et Mme de Staël. Paris: Centro Nazionale di Studi LeopardianiFondazione Garzanti, 1999, p. 3. Pode-se aqui ainda destacar sobre a relação de Leopardi com a França e, em particular, com a obra de Madame de Staël a pesquisa de Serban. Ver aqui SERBAN, Nicolas. Leopardi et la France. Essai de littérature comparée. Paris: Librairie ancienne honoré champion, 1913, pp. 127-160. Entre os escritores que realizaram, nesse período, o Grand Tour, Sade apresenta certa especificidade: não amava viajar e diferentemente de muitos literatos do século XVIII em que o Grand Tour representava um estágio de formação, ou seja, de ampliação do saber, Sade, em certo sentido, foi obrigado a realizar a viagem à Itália como busca de refúgio, fuga, em um lugar de acolhimento no qual pudesse passar sem ser percebido (Cf. MARQUESE DI SADE, Donatien-Alphonse-François. Viaggio in Italia. Trad. it. Giovanni Ferrara degli Uberti, Torino: Bollati Boringhieri, 1996, p. VII. Já Stendhal afirmou em seu escrito Passeggiate romane, publicado apenas em 1892, de ter estado seis vezes em Roma: algo que não constituiria um grande mérito, mas essa recordação serviria para despertar a confiança do leitor (Cf. STENDHAL. Passeggiate romane. trad. it. Massimo Colesanti. Milano: Garzanti, 2009 (2ª ed.), p. 5; . La Certosa di Parma. Trad. it. Stefano Agosti. Milano: Oscar Mondadori, 2011.

${ }^{272}$ Cf. PLACANICA, Augusto. Leopardi e il Mezzogiorno del mondo, p. 26. 
era a sanção do declínio contínuo dos estados islâmicos da África setentrional e da Ásia anterior, mas também o sintoma da fragilidade geral da cristandade mediterrânea) ${ }^{273}$.

Ademais, as transformações econômicas, decorrentes da descoberta das Américas e as suas consequências, levaram ainda ao declínio as antigas categorias sociais vinculadas a camadas pertencentes à lgreja e à feudalidade: pilares, portanto, do mundo medieval ${ }^{274}$. A formação de uma burguesia da produção, comércio, artes suplantou, em virtude de o crescente poder econômico, esses antigos estamentos feudais: algo decorrente também da capacidade inventiva da nova classe. Daí a conquista crescente do mundo, propiciando igualmente uma revolução agrária e industrial.

Além desses acontecimentos, destacam-se ainda o desenvolvimento de uma classe de funcionários eficientes para o serviço de estados absolutos e racionalmente estruturados, o potenciamento dos conhecimentos científicos e das tecnologias, pois úteis e fecundas, ultrapassando todos os obstáculos religiosos e ideológicos, e os instrumentos de poder e de prosperidade econômica. Ademais, conta-se também com o experimento e a reflexão racional onde a religião e, sobretudo, a supertição haviam durante séculos assentado os próprios edifícios. Esses acontecimentos tinham produzido, acompanhado e legitimado uma lenta ascensão dos estados da Europa central e norte ocidental, sobretudo, de fé protestante, ao ápice da modernidade. Os países que se apresentaram no Atlântico e no Báltico, da França à Inglaterra,

273 PLACANICA, Augusto. Leopardi e il Mezzogiorno del mondo, p. 26: "dopo la scoperta dell'America, decennio dopo decennio, l'Europa mediterrânea - che con la Spagna [...] - aveva [...] definitivamente perduto la sua antica primazia, a vantaggio delle società nordoccidentali, o, meglio, delle nuove linee di traffico sull'Atlantico, che nella prospettiva di un furioso processo di ammodernamento, avevano spostato gli assi dell'economia nel mondo, facendo di quell'antico mare interno, che era stato il Mediterraneo, un universo secondario e quase dimenticato (e Lepanto, nel 1571, era la sanzione del declino inarrestabile degli stati islamici dell'Africa settentrionale e dell'Asia anteriore, ma anche il sintomo della generale debolezza della cristianità mediterranea)".

274 É relevante indicar nesse momento a reflexão de Paul Hazard sobre a crise da consciência europeia e as questões concernentes à Itália. Hazard comenta sobre certa recordação de Roma que ainda permanecia, não obstante a Itália já se encontrar em decadência, mas que os viajantes a percorriam ainda no Grand Tour. Nesse sentido, ver o terceiro capítulo intitulado Dal mezzogiorno al Nord da edição italiana de sua obra (Cf. HAZARD, Paul. La crisi della coscienza europea [1961]. Trad. it. a cura di Paolo Serini, Torino: UTET, 2007 (9ª̊ed.), pp. 41-60. Contribuíram ainda para essas análises, as reflexões de Marx, Weber, Sombart, Tawney, Groethuysen e Croce. 
da Holanda à Suécia, da Dinamarca à Alemanha, conheceram assim um desenvolvimento até então jamais percebido ${ }^{275}$.

Isso justifica a lenta separação que ocorre - após essas transformações - da Europa meridional com toda a bacia do Mediterrâneo, pois desde a Espanha à Itália, da Grécia à Turquia, a Europa meridional começou assim a se separar daquele "corpo único" que havia sido a antiga Europa cristã, na qual a civilização, tendo a Itália como o seu sustentáculo, havia então passado, da Ásia e da África, aos "brejos da Irlanda" e às "estepes remotas russas" 276 . As várias transformações econômicas e tecnológicas ocorridas entre o século XVII e XVIII possibilitaram, ao mesmo tempo na Europa, uma visão diversa da história, ou seja, de a história não ser imutável, mas propensa também à decadência.

No interior dessas sociedades desenvolvidas se origina ainda, em virtude dos acontecimentos, a ideia de progresso ${ }^{277}$. Por conseguinte ocorreu em tais culturas, que mesmo não tendo mais necessidade de se defender do "prestígio do passado", se curvasse ainda em direção desse mesmo passado, agora com $o$ afeto respeitoso que se deve a quem, ou bastante criança ou bastante velho, estivesse distante, e para sempre, do nosso viver e do nosso sentir $^{278}$.

Isso explica igualmente como na continuidade começou a se difundir, com mais intensidade do que anteriormente, a visão de um Mezzogiorno da Europa e, quanto à Itália, em especial, um Mezzogiorno como

algo diferente da normalidade europeia do tempo. Para além das funções pedagógicas do Grand Tour, que tinha às costas uma tradição secular, [...] com os seus novos rigores inéditos $e$ as suas exigências de ordem e de eficiência, a indicar no Mezzogiorno em geral - e na Itália, em particular, tornada o Mezzogiorno - a sede de um passado para

${ }^{275}$ Cf. PLACANICA, Augusto. Leopardi e il Mezzogiorno del mondo, p. 27. Sobre as novas tendências intelectuais na Itália, fruto da experiência iluminista italiana, ver ASOR ROSA, Alberto. Storia europea della letteratura italiana. Dalla decadenza al Risorgimento. Torino: Einaudi, 2009, pp. 226-306.

${ }^{276}$ Cf. PLACANICA, Augusto. Leopardi e il Mezzogiorno del mondo, p. 27.

277 Cf. PLACANICA, Augusto. Leopardi e il Mezzogiorno del mondo, p. 29.

${ }^{278}$ Cf. PLACANICA, Augusto. Leopardi e il Mezzogiorno del mondo, p. 29. 
não ser imitado, não, certamente, mas de qualquer modo, para sonhar e para reviver: um mundo de sensações mais doces e mais cordiais, um clima mais terno, e dos engenhos - no bem e no mal - mais ágeis, mais fantasiosos e mais originais, talvez amantes daqueles extremos à qual a medietas burguesa havia dado remédio ${ }^{279}$.

Pode-se ainda acrescentar, a essa compreensão do Mezzogiorno europeu, ou mais especificamente italiano, a visão tipicamente dos países que efetivaram a Modernidade, e presenciaram igualmente o desaparecimento de certa dimensão da humanidade, ou seja, certa vitalidade e espontaneidade vivida anteriormente ao advento das novas ideias e técnicas. Desse modo, a ausência ou inadequação típica dos povos meridionais ao progresso constituía, por sua vez, uma "sombra", mas também "luz" de um mundo que havia se recusado ao progresso, pois se, de modo geral, o progresso havia conquistado a sua dimensão de valor positivo universal, do mesmo modo permanecia a dimensão nostálgica de um mundo desaparecido do horizonte dos espíritos pensantes $^{280}$.

Com essa dimensão nostálgica, que surge também com o progresso das nações desenvolvidas, o Mezzogiorno se torna, com efeito, o objeto e o instrumento de uma insatisfeita rêverie, mais do que a eterna gloriosa Roma, agora Veneza e Nápoles, as antigas estrelas do antigo Mediterrâneo, vinham constituir dois mundos à parte, universos do diverso. Nessa reconstrução de um passado antigo contribuíam novos saberes aliados a "sensibilidades antigas". Entre as ciências da época, que contribuíram com essa reconstrução, vale aqui lembrar a Antropologia, limitada, por sua vez, às categorias gerais do ambiente, no qual o indivíduo assumia um escasso papel diante do condicionamento impreterível dos elementos climáticos, e havia se apresentado, acima do indivíduo, a ideia auroral da massa, a qual parecia

${ }^{279}$ Ibidem: "qualcosa di diverso dalla normalità europea del tempo. Al di là delle funzioni pedagogiche del Grand Tour, che aveva alla spalle una tradizione secolare, [...] con i suoi nuovi inediti rigori e le sue esigenze di ordine e di efficienza, a indicare nel Mezzogiorno in generale e nell'Italia in particolare, divenuta il Mezzogiorno - la sede di un passato da non imitare, no, certo, ma comunque da sognare e da rivivere: un mondo di sensazioni più dolci e più cordiali, un clima più tenue, e degl'ingegni - nel bene e nel male - più spigliati, più fantasiosi e più originali, magari amanti di quegli estremi a cui la medietas borghese aveva posto rimedio".

${ }^{280}$ Cf. PLACANICA, Augusto. Leopardi e il Mezzogiorno del mondo, p. 29. 
haver conquistado um protagonismo inédito, independente dos indivíduos que a compunham ${ }^{281}$.

Compunham ainda a imagem dessa "nova visão", ao lado dos elementos anteriormente apresentados,

um grumo de reminiscências e de conhecimentos, assimilados e propostos, de novo, feitos de história antiga e de antigos esplendores, de mitos e de poemas imortais, de personagens e culturas e acontecimentos e obras de arte que indicam civilizações antigas, fundadoras da Europa moderna. Daqui o fascínio das paisagens, das pinturas, das ruínas, e até das linguagens e das inscrições, que fizessem sentir ainda próximo aquele mundo já passado, ou que pelo menos restituíssem disso para o coração a atmosfera feita de uma história tornada sonho e de um sonho que se pôs na história ${ }^{282}$.

O Mezzogiorno tornou-se cada vez mais o universo do mundo sonhado, pois foi precisamente no interior do mundo moderno e de seu ordenamento racional que ocorreu essa volta do mundo antigo nas suas expressões espirituais. Ademais, esse "desejo" de retornar às fontes remotas marca a experiência que aproximou alguns homens na sociedade moderna. Se antes o Grand Tour assumia a dimensão de mera experiência de vida espiritual, tornouse em seguida, de acordo com Placanica, "uma peregrinação às fontes do

${ }^{281}$ Cf. PLACANICA, Augusto. Leopardi e il Mezzogiorno del mondo, p. 30. Em seu estudo sobre Leopardi, Cassano comenta sobre as frequentes referências leopardianas às diferenças geográficas e climáticas, algo que exercem um papel importante no Espírito das Leis de Montesquieu, mas também na obra de Madame de Staël (Cf. CASSANO, Franco. Oltre il nulla. Studio su Giacomo Leopardi, p. 4. Ver ainda De Staël, Madame. Corinna o L'Italia, p. 287). Sobre as influências climáticas pode-se ainda indicar as considerações de Montesquieu presentes no livro XIV a XVII do Espírito das Leis (Cf. MONTESQUIEU. O espírito das leis [1748]. Trad. br. Cristina Murachco. São Paulo: Martins Fontes, 2000 (2ª̃ed.), pp. 239-291).

282 PLACANICA, Augusto. Leopardi e il Mezzogiorno del mondo, p. 30: "un grumo di reminiscenze e di conoscenze, assimilate e riposte, fatte di storia antica e di antichi splendori, di miti e di poemi immortali, di personaggi e culture ed eventi ed opere d'arte contrassegnanti le civiltà antiche, fondatrici dell'Europa moderna. Da qui il fascino dei paesaggi, dei dipinti, delle rovine, e perfino dei linguaggi e delle iscrizioni, che fecessero sentire ancora vicino quel mondo ormai passato, o che almeno ne restituissero al cuore l'atmosfera, fatta di una storia diventata sogno e di un sogno collocantesi nella storia". 
mundo civil"283, e com a Itália-Roma que se torna "Mutter Erde da civilização europeia" 284 .

Nesse novo momento da experiência moderna, ao assumir a Itália-Roma o papel de "grande mãe da civilização" [grande madre della civiltà] ${ }^{285}$, ocorreu, com efeito, um deslocamento do Mezzogiorno da Itália, pois foi invocado

bem além de Roma, bem além do tempo e do espaço da antiga Roma [...] simbolizando, e contendoos completamente, aqueles valores de harmonia de compostura, aquela antichissima sapienza itálica da qual Vico havia falado e que Cuoco, discípulo de Vico e de Galanti, teria renovado no mito do Platão na Itália. Aquele mesmo Mezzogiorno da Itália, do qual se sabia tão pouco, e das cujas condições socioeconômicas atuais se pensava tão mal, pois, mal projetado na majestade do passado, tornava-se um éden irrepetível, com as suas paisagens, os seus momentos, as suas ruínas, a sua própria natureza de cruzamento de todas as civilizações do passado ${ }^{286}$.

283 PLACANICA, Augusto. Leopardi e il Mezzogiorno del mondo, p. 31: "un pellegrinaggio alle sorgenti del mondo civile".

${ }^{284}$ Cf. PLACANICA, Augusto. Leopardi e il Mezzogiorno del mondo, p. 31: "Mutter Erde della civiltà europea".

285 Cf. PLACANICA, Augusto. Leopardi e il Mezzogiorno del mondo, p. 31.

${ }^{286}$ PLACANICA, Augusto. Leopardi e il Mezzogiorno del mondo, p. 31: "ben al di là del tempo e dello spazio dell'antica Roma - a simboleggiare, e addiritura a contenerli, quei valori di armoni e di compostezza, quell'antichissima sapienza italica di cui aveva parlato Vico, e che Cuoco, discepolo ideale di Vico e di Galanti, avrebbe rinnovato nel mito del Platone in Italia. Quello stesso Mezzogiorno d'Italia, di cui cosi male si pensava, poi, appena proiettato nella maestà del passato, diventava un éden irripetibile, coi sui paesaggi, i suoi monumenti, le sue rovine, la sua stessa natura di crocevia di tutte le civiltà del passato". A antiquissima sapientia é um topos retórico renascentista presente na filosofia de Marsilio Ficino (1433-1499) e de Pico della Mirandola ( ). Esse topos decorre, de início, do "mito" da prisca theologia formulada por Ficino com base na convicção de que Orfeu, Hermes Trismegisto, Pitágoras e Zoroastro teriam vivido antes de Platão, constituindo assim as fontes da Filosofia platônica. Nesse sentido, a tradução ficiniana do Corpus platonicum fazia parte de um projeto mais amplo de recuperação das fontes do platonismo, em que Ficino destacava uma antiquíssima tradição sapiencial das remotas origens préelenicas, ou seja, a prisca theologia e da herança espiritual de Platão transmitida na era cristã e conservada intacta nas obras de seus epígonos. Tendo como primeiro filósofo dessa sabedoria Hermes Trismegisto - autor dessa teologia -, Ficino apresenta, em seguida, Orfeu, Aglaufemo, Pitágoras, Filolau, chegando até Platão. Contudo, Ficino não compreendeu a prisca theologia como uma tradição unitária. Na reflexão ficiniana revela-se também certa tese da concórdia entre doutrinas platônico-herméticas e teologia cristã (Cf. VITALE, Errico. Saggio introduttivo. In: FICINO, Marsilio. Teologia platônica [1482]. Trad. it. Errico Vitale, Milano: Bompiani, 2011, pp. VI-XCl. Esse topos retórico é retomado por Giambattista Vico (1668-1744) em seu escrito De antiquissima italorum sapientia (1710) e em certas formulações presentes nas "Risposte" de 1711 e 1712. Sobre essas questões ver VICO, Giambattista. De antiquíssima italorum sapientia [1710]. In: Opere filosofiche. Firenze: Sansoni, 1971, pp. 56-131; filosofiche, pp. 132-144; Risposta del signor Giambattista Vico [1711]. In: Opere . Risposta di Giambattista Vico [1712]. In: Opere filosofiche, 
Em tal contexto pode-se aqui reenviar ao exemplo de Goethe, considerado aquele que ofereceu uma "síntese admirável" [sintesi mirabile] ${ }^{287}$ de toda uma imagem: "'A Itália, sem a Sicília, não deixa qualquer imagem na alma: aqui está a chave de tudo'”288. A Sicília sugere a Goethe uma paisagem homérica, pois de sua visita à Itália e de sua experiência siciliana surge o "projeto de Nausicaa" ${ }^{289}$, ou seja, "um concentrado dramático da Odisséia"290. Não obstante se tratasse de um empreendimento inexequível, era preciso não descurar da distinção fundamental entre drama e poesia épica. Para a memória de sua experiência siciliana, Goethe contava com "a presença e a atividade de um hábil artista"291, a saber, Chistoph Heinrich Kniep, unidas às suas

pp. 145-168. Ver também VANDER, Fabio. De philosophia italica. Modernità e politica in Vico e Cuoco, pp. 33-146.

${ }^{287}$ Cf. PLACANICA, Augusto. Leopardi e il Mezzogiorno del mondo, p. 31.

288 GOETHE, Johann W. Viaggio in Italia [1816-1817]. Trad. it. Emilio Castellani, Milano: Mondadori, 2011, p. 280. Em sua estada a Nápoles Goethe entra em contato direto com pessoas ilustres, a saber, Gaetano Filangieri, o qual Ihe fala de Giambattista Vico. Goethe comenta que Filangieri o entreteu falando "sobre um escritor de outros tempos, em cuja profundidade insondável esses amigos italianos modernos das leis encontram bom exemplo e conforto; o seu nome é Giambattista Vico, e o consideram superior a Montesquieu (Cf. GOETHE, Johann W. Viaggio in Italia [1816-1817], p. 212).

${ }^{289}$ Ibidem, p. 330.

290 Ibidem, pp. 330-331. Roberto Fertonani comenta, no prefácio ao livro de Goethe, que o material correspondente à viagem "reflete na estética as ideias que se podem resumir no binômio 'nobre simplicidade e tranquila grandeza' do Winckelmann. Segundo esse cânone, inovador em relação ao passado, mas coerente com a mentalidade do século XVIII ainda intacta de sensibilidade romântica, tinha sido educado Goethe, que, todavia, apenas na Itália se aproximará com impenho da história da arte na antiguidade do Winckelmann, o qual lhe ensina o método histórico baseado no estudo das sucessões de estilos [...]"(Cf. FERTONANI, Roberto. Goethe, L'Italia e gli italiani. In: GOETHE, Johann W. Viaggio in Italia [1816-1817], p. $X V$. Ainda sobre Winckelmann e a divinização da vida nos antigos com o caráter festivo deles ver RIGONI, Mario Andrea. II pensiero di Leopardi. Torino: Aragno, 2010, pp. 3, 28. Chabod, ao considerar a reflexão de Winckelmann sobre a Grécia, destaca o sentido de que nela surgiram os tempos da plena iluminação e liberdade, onde também a arte se tornara mais livre e sublime, pois o estilo mais antigo estava construído sobre um sistema de regras apreendidos da natureza, mas em seguida se distanciaram dela e se tornaram um ideal. Daí se produzia mais segundo as prescrições dessas regras do que segundo a natureza, a qual devia imitar: porque a arte havia formado para si uma natureza (Cf. CHABOD, Federico. L'idea di nazione. pp. 36-38); Ver aqui também ASOR ROSA, Alberto. Storia europea della letteratura italiana. Dalla decadenza al Risorgimento. Vol. II, Torino: Einaudi, 2009, pp. 340-341.

${ }^{291}$ GOETHE, Johann W. Viaggio in Italia [1816-1817], p. 331. Fertonani comenta ainda acerca de certas reservas por parte de alguns leitores da época em relação ao texto Italienische Reise de Goethe, ou seja, sobre a sua "parcialidade": "podemos dizer que a facciosidade, desse vianjante sui generis, que se encontra na Itália e não permanece mais do que três horas em Florença, passa por Assis e não digna de um olhar a igreja de São Francisco, em Roma negligencia os mosaicos de Santa Maria em Trastevere e em Palermo as maravilhosas catedrais árabe-normanas. A lista poderia continuar ao infinito, a polêmica tem também uma data de início: em uma reunião tida na embaixada da Prússia em Roma, quando a primeira parte da Italienische Reise, lida em público, havia suscitado as críticas dos 
"esporádicas" ou até "frágeis tentativas" para "conservar uma série de imagens precisas e bem escolhidas dos lugares mais interessantes e das suas particularidades, em esboços ou mesmo [...] em quadros" ${ }^{292}$. Isso justifica aquele desejo cada vez mais forte que afetava a Goethe.

\subsection{Características naturais do meridione e setentrião: as formulações leopardianas}

$\mathrm{Na}$ época de Leopardi, aquela correspondente à primeira metade do século XIX, permanecia ainda a grande tradição de exaltação da Itália, e do Mezzogiorno da Itália: algo que decorria, em grande parte, da experiência dos viajantes estrangeiros. Aos olhos desses viajantes a civilização antiga parecia se refugiar naquele ângulo apartado do mundo ${ }^{293}$. Para se abordar a questão do meridione leopardiano se retoma aqui, de início, o Discorso de 1824, uma vez que se trata ainda da indagação de Leopardi acerca do atraso italiano ante as demais nações europeias. Ademais, esse argumento se reporta, por sua vez, às preocupações morais de Leopardi na sua crítica aos costumes dos italianos ${ }^{294}$.

presentes desiludidos de se encontrar diante de uma relação tão unilateral e incompleta" (Cf. FERTONANI, Roberto. Goethe, L'Italia e gli italiani. In: GOETHE, Johann W. Viaggio in Italia [1816-1817], p. XV).

292 Cf. GOETHE, Johann W. Viaggio in Italia [1816-1817], p. 331.

${ }^{293}$ Cf. PLACANICA, Augusto. Leopardi e il Mezzogiorno del mondo, p. 34.

${ }^{294}$ Conforme Cassano, na reflexão sobre a problemática leopardiana da diferença entre civilização meridional e civilização setentrional, a da diferença entre antigos e modernos foi mais abordada nos estudos leopardianos. Leopardi, em várias passagens do Zibaldone di pensieri chega a traçar uma forte articulação entre as duas diferenças. Por isso é relevante, em conformidade com o seu pensamento, considerar essa conexão, uma vez que segundo 0 fragmento 4256 do Zibaldone, Leopardi afirma: "A antiguidade mesma e a maior naturalidade dos antigos, é uma espécie de meridionalidade no tempo" (Cf. LEOPARDI, Giacomo. Zibaldone di pensieri, fragmento 4256 (14.03.1827), pp. 2335-2336: "L'antichità medesima e la maggior naturalezza degli antichi, è una specie di meridionalità nel tempo"). Essa diferença entre civilização meridional e setentrional não ocupa, porém, um estatuto menor no pensamento de Leopardi, pois é preciso se considerar em suas abordagens, quer a contribuição de Montesquieu quer aquelas de Mme. De Staël. Daí se destacar nessas influências as referências constantes a diferenças geográficas e climáticas, as quais assumem um papel importante nas obras desses pensadores. Nesse sentido, ver aqui DOLFI, Ana. Leopardi e il pensar filosofico di Madame de Staël. In: Leopardi e la cultura europea. Atti del convegno internazionale dell'Università di Lovanio (Lovanio - 10-12 dicembre, 1987), Roma: BulzoniLeuven University press, 1989, pp. 191-205). 
Se a abordagem do Discorso leopardiano considerou as razões desse atraso italiano na "falta de sociedade" [mancanza di società] ${ }^{295}$, trata-se agora, com base ainda no Discorso, acrescentar "como outra razão dos mesmos ou semelhantes efeitos", ou seja, "a natureza do clima e do caráter nacional que dele depende e resulta" ${ }^{296}$. Para uma abordagem dessa outra "razão" valendose da ordem natural, Leopardi considera a relação entre povos meridionais e povos setentrionais. Trata-se, portanto, da compreensão dos "efeitos" naturais sobre a constituição do caráter das sociedades.

No seu Discorso, Leopardi tem como pressuposto de seus argumentos certo "paradoxo" [paradosso]. Conforme ele apresenta na seguinte passagem:

É tão admirável e semelhante ao paradoxo, quanto verdadeiro, que não exista nem indivíduo, nem povo tão próximo à frieza, à indiferença, à insensibilidade, e a certo grau tão alto e profundo e constante de frieza, insensibilidade e indiferença, como aqueles que são, por natureza, mais vivos, mais sensíveis, mais calorosos $^{297}$.

No entender de Leopardi, esses "povos" [popol] ou "indivíduos" [individui], quando postos em "um estado e em circunstâncias políticas ou quaisquer que sejam", os efeitos serão, portanto, opostos à natureza sensível deles.

Como Leopardi descreve tal reação? Nessas circunstâncias em que nada conceda "à imaginação e à ilusão, aliás, tudo contribua para o desengano, este desengano, por causa da própria vivacidade da natureza deles, e em razão direta dessa vivacidade, é completo, total, fortíssimo, profundíssimo"298. Esse é, portanto, o paradoxo que Leopardi diz existir entre p. 79 .

${ }^{295}$ Cf. LEOPARDI, Giacomo. Discorso sopra lo stato presente dei costumi degl'italiani,

${ }^{296}$ Cf. LEOPARDI, Giacomo. Discorso sopra lo stato presente dei costumi degl'italiani, p. 79: "come altra cagione de' medesimi o simili effetti"; "la natura del clima e del carattere nazionale che ne dipende e risulta".

${ }^{297}$ LEOPARDI, Giacomo. Discorso sopra lo stato presente dei costumi degl'italiani, p. 79: "Ė tanto mirabile e símile a paradosso, quanto vero, che non v'há né individuo né popolo si vicino alla freddezza, all'indifferenza, all'insensibilità, e ad un grado cosi alto e profondo e costante di freddezza, insensibilità e indifferenza, come quelli che per natura sono più vivaci, più sensibili, più caldi".

298 LEOPARDI, Giacomo. Discorso sopra lo stato presente dei costumi degl'italiani, p. 79: "all'immaginazione e all'illusione, anzi tutto contribuisca al disinganno, questo disinganno per la vivacità stessa della loro natura e in ragione diretta di essa vivacità è completo, totale, fortíssimo, profondissimo". 
certa constituição natural de povos e indivíduos mais sensíveis e calorosos e os efeitos contrários em certas circunstâncias da vida civil.

Certamente os argumentos leopardianos no Discorso pretendem enfrentar justamente certo "caráter nacional" [carattere nazionale] das "nações civis" [nazioni civil], por se tratar de uma abordagem relativa à constituição dos "costumes" [costumi] e de seus aspectos antropológicos e morais: compreender a natureza da vida civil de certos povos, sobretudo, naquilo que contribuiu para os novos fundamentos morais modernos. Daí povos e indivíduos de natureza calorosa e vivaz revelarem "indiferença" ante específicas circunstâncias políticas ou quaisquer que sejam. Leopardi escreve:

A indiferença que disso resulta é perfeita, muito arraigada, muito constante; a inatividade, se assim se pode chamar, muito eficaz; o menosprezo muito eficaz; a frieza é realmente gelo, como ocorre no grande calor, em que os vapores são elevados por ele a tanta elevação que se apertando ali no gelo mais duro, cai despedaçado em granizo ${ }^{299}$.

Com essa analogia entre fenômenos naturais e os seus efeitos e certa natureza de povos, Leopardi introduz, em seguida, a questão que, nesse momento do seu Discorso, completa os argumentos anteriores sobre a situação moral e política de algumas nações ${ }^{300}$.

Os povos setentrionais menos calorosos nas ilusões são também menos frios no desengano, mas, são menos propensos a esse desengano. Pouca coisa basta para alimentar a imaginação deles, para conservar as ilusões deles. Do mesmo modo falo dos indivíduos pouco sensíveis ${ }^{301}$.

Para argumentar sobre essa analogia entre físico e moral, Leopardi aborda, na continuidade de sua exposição, a questão do "sentimento"

299 LEOPARDI, Giacomo. Discorso sopra lo stato presente dei costumi degl'italiani, p. 79: "L'indifferenza che ne risulta è perfetta, radicacissima; la noncuranza effettivissima; la freddezza è vero ghiaccio, come accade nel gran caldo, che i vapori sono da esso elevati a tanta altezza che quivi stringendosi nel più duro gelo, precitano ridotti in gragnuola".

300 Ver nesse sentido LEOPARDI, Giacomo. Discorso sopra lo stato presente dei costumi degl'italiani, p. 79.

301 LEOPARDI, Giacomo. Discorso sopra lo stato presente dei costumi degl'italiani, p. 79: "I popoli setentrionali meno caldi nelle illusioni, sono anche meno freddi nel disinganno. Di più sono meno facili a questo disinganno. Poca cosa basta ad alimentare la loro immaginazione, a conservare le loro illusioni. Così dico degl'individui poco sensibili”. 
[sentimento] e da "imaginação" [immaginazione], de forma ainda genérica, ou seja, como disposições. Conforme ele escreve,

a grande força do sentimento e da imaginação precisa de muito pasto, de ajudas vivas, de algum sustento nas coisas reais. De outro modo dirigindo a sua força e o seu calor em si mesma se consome sozinha tanto mais rápida e mais completamente, quanto essa força e esse calor são maiores e ativos. Um espírito delicado posto em contato com a dureza das coisas reais, e friccionado, por assim dizer, como elas, torna-se tão mais rápido e mormente tão embotado quanto era mais perspicaz e mais fino, tão mais facilmente $e$ profundamente endurece quanto era mais delicado, tenro e macio. Tal como ocorre no físico, ocorre no moral $^{302}$.

Leopardi apresenta aqui os pressupostos de suas próximas formulações sobre a situação em que se encontram os povos e suas disposições naturais ante as mudanças das circunstâncias civis e políticas em que se encontram. Daí a disposição desses povos em meridionais e setentrionais ser articulada igualmente a qualidades contrárias a dado modo de ser e se constituir. Nesse sentido ele argumenta:

se nós consideramos, de um lado, essa propriedade inseparável dos espíritos vivazes e sensíveis, isto é, de cair tão facilmente e altamente nas qualidades contrárias (propriedade comum a todos os excessos sempre propensos e próximos aos seus opostos), e isso também em paridade com outras circunstâncias com respeito aos espíritos descansados e sóbrios ou frios e insensíveis por natureza; e de outro lado, que não apenas essa paridade de circunstâncias, no nosso caso não tem lugar, mas que a Itália está em um estado, quanto às coisas reais que favorecem a imaginação e às ilusões, muito inferior ao de todas as outras nações civis (falo das circunstâncias da vida, e

${ }^{302}$ LEOPARDI, Giacomo. Discorso sopra lo stato presente dei costumi deglitaliani, pp. 79-80: "la gran forza del sentimento e dell'immginazione ha bisogno di molto pascolo, di aiuti vivi, di qualche sostentamento nelle cose reali. Altrimenti rivolgendo la sua forza e il suo calore in se stessa si consuma da sè tanto più completamente quanto essa forza ed esso calore è più grande e attivo. Uno spirito delicato messo a contatto della durezza delle cose reali, e confricato per cosi dire con esse, diviene tanto più presto e tanto maggiormente ottuso quanto era più acuto e più fino, e tanto più facilmente e profondamente incallisce quanto era più delicato, tenero e molle. Così accade nel físico, cosi nel morale". 
não daquelas do clima e naturais, que, aliás, prejudicam pelas ditas razões) ${ }^{303}$.

Trata-se, portanto, de sua interpretação daquilo que se transformou a Itália no presente, se compreendida com base na nova configuração entre as nações civis e a relação entre meridional e setentrional. Se, no passado, a Itália superou "duas vezes" [due volte] ${ }^{304}$ de "imaginação" [immaginazione] ${ }^{305}$ as demais nações, ou seja, na Antiguidade e no Renascimento, não se pode, porém, deixar de se "surpreender" que

os italianos, a mais vivaz de todas as nações cultas e a mais sensível e calorosa por natureza, seja agora no hábito e no caráter adquirido a mais morta, a mais filósofa na prática, a mais circunspecta, indiferente, insensível, a mais difícil de ser movida pelas coisas ilusórias $^{306}$.

Nesse novo estado de coisas no qual a Itália se encontrava e se transformou, se lembrada a partir do passado, Leopardi destaca assim a relevância que ocupa a "imaginação" [immginazione] na cultura dos povos, a Itália no presente - como apresenta o Discorso - é "muito menos governada pela imaginação" [molto meno governata dall'immaginazione] ${ }^{307}$. Isso justifica haver se tornado uma nação,

a mais reflexiva no operar e na conduta, a mais pobre, aliás, desprovida totalmente de obras da imaginação (nas quais uma vez, aliás, duas vezes, superou de

303 LEOPARDI, Giacomo. Discorso sopra lo stato presente dei costumi degl'italiani, $\mathrm{p}$. 80: "se noi consideriamo da una parte questa proprietà inseparabile dagli spiriti vivaci e sensibili, cioè di cadere tanto più facilmente e altamente nelle qualità contrarie (proprietà comune a tutti gli eccessi sempre proclivi e vicini ai loro opposti), e cio anche in parità delle altre circostanze rispetto agli spiriti riposati e temperati o freddi e insensibili per natura; e dall'altra parte che non solo questa parità di circostanze nel nostro caso non há luogo, ma che l'Italia è in uno stato, quanto alle cose reali che favoriscono l'immaginazione e le illusioni, molto inferiore a quello di tutte l'altre nazioni civili (parlo delle circostanze della vita, e non di quelle del clima e naturali, che anzi nocciono per le dette ragioni)".

p. 80 .

${ }^{304}$ Cf. LEOPARDI, Giacomo. Discorso sopra lo stato presente dei costumi degl'italiani,

${ }^{305}$ Cf. LEOPARDI, Giacomo. Discorso sopra lo stato presente dei costumi degl'italiani, p. 80 .

306 LEOPARDI, Giacomo. Discorso sopra lo stato presente dei costumi degl'italiani, p. 80: "gl'Italiani la più vivace di tutte le nazioni colte e la più sensibile e calda per natura, sia ora per assuefazione e per carattere acquisito la più morta, la più fredda, la più filosofa in pratica, la più circospetta, indifferente, insensibile, la più difficile ad esser mossa da cose illusorie".

${ }^{307}$ Cf. LEOPARDI, Giacomo. Discorso sopra lo stato presente dei costumi degl'italiani, p. 80 . 
longe todas as nações que agora nos superam), de poesia qualquer (não falo de versificação) de obras sentimentais, de romances, e a mais insensível à consequência dessas tais obras e gêneros (ou próprias ou estrangeiras) ${ }^{308}$.

Se comparada ao passado $^{309}$, a situação da Itália causa no presente espanto, conforme Leopardi expõe, sem deixar também de admirar que, no presente,

os povos setentrionais e, em princípio, os mais setentrionais sejam hoje os mais calorosos de espírito, os mais imaginativos de fato, os mais maleáveis e governáveis pelas ilusões, os mais sentimentais quer de caráter quer de espírito, quer de costumes, os mais poetas nas ações e na vida, e nos escritos e literaturas ${ }^{310}$.

${ }^{308}$ LEOPARDI, Giacomo. Discorso sopra lo stato presente dei costumi deglitaliani, pp. 80-81: "la più ragionatrice nell'operare e nella condotta, la più povera, anzi priva affatto di opere d'immaginazione (nelle quali una volta, anzi due volte, superò di gran lunga tutte le nazioni che ora ci superano), di poesia qualunque (non parlo di versificazione), di opere sentimentali, di romanzi e la più insensibile all'effetto di queste tali opere e generi (o proprie o straniere)".

${ }^{309}$ Deve-se destarcar aqui o apelo leopardiano ao passado de glória da Itália como sentimento de recusa ao seu presente estado moderno. Nesse sentido, ver aqui as poesias de um Leopardi civil presentes nos Canti, a saber, All'ttalia [O patria mia, vedo le mura e gli archi/ E le colonne e i simulacri e l'erme/ Torri degli avi nostri,/ Ma la gloria non vedo ....; Sopra il monumento di Dante che si preparava in Firenze [O Italia, a cor ti stia/ Far ai passati onor; che d'altrettali/ Oggi vedove son le tue contrade,/ Nè v'è chi d'onorar ti si convegna./ Volgiti indietro, e guarda, o patria mia,/ Quella schiera infinita d'immortali ...]; Ad Angelo Mai, quand'ebbe trovato $i$ libri di cicerone della Repubblica [italo ardito, a che giammai non posi/ Di svegliar dalle tombe/ I nostri padri? ed a parlar gli meni/ A questo secol morto, al quale incombe/ Tanta nebbia di tedio? E come or vieni/ Sì forte a' nostri orecchi e sì frequente,/ Voce antica de' nostri,/ Muta sì lunga etade? e perchè tanti/ Risorgimenti? ...] Nelle nozze della sorella Paolina [O verginete, a voi/ Chi de' perigli è schivo, e quei che indegno/ $E$ della patria e che sue brame e suoi/ Volgari affetti in basso loco pose,/ Odio mova e disdegno;/ Se nel femmineo core/ D'uomini ardea, non di fanciulle, amore ...]; $A$ un vincitore nel pallone [Alla patria infelice, o buon garzone/ Sopravviver ti doglia./ Chiaro per lei stato saresti allora/ Che del serto fulgea, di ch'ella è spoglia,/ Nostra colpa e fatal. Passò stagione;/ Che nullo di tal madre oggi s'onnora:/ Ma per te stesso al polo ergi la mente./ Nostra vita a che val? ...]; Bruto minore [Fremono i poggi, dalle somme vette/ Roma antica ruina;/ Tu sì placida sei? Tu la nascente/ Lavinia prole, e gli anni/ Lieti vedesti, e i memorandi allori;/ E tu su l'alpe l'immutato raggio/ Tacita verserai quando ne' danni/ Del servo italo nome,/ Sotto barbaro piede/ Rintronerà quella solinga sede ...]; Alla primavera, o delle favole antiche [Forse alle stanche e nel dolor sepolte/ Umane menti riede/ La bella età, cui la sciagura e l'altra/ Face del ver consunse/ Innanzi tempo? Ottenebrati e spenti/ Di febo i raggi al misero non sono/ In sempiterno? ed anco,/ Primavera odorata, inspiri e tenti/ Questo gelido cor, questo ch'amara/ Nel fior degli anni suoi vecchiezza impara? ...]; (Cf. LEOPARDI, Giacomo. Canti [1816-1837]. A cura di Ugo Dotti. Milano: Feltrinelli, 2006 (5eㄹ. pp. 207, 215, 227-228, 244-245, 252, 260-261 e 265). Ver também BLASUCCI, Luigi. I tempi dei "Canti". Nuovi studi leopardiani. Torino: Einaudi, 1996, pp.3-61.

${ }^{310}$ LEOPARDI, Giacomo. Discorso sopra lo stato presente dei costumi degl'italiani, p. 81: "i popoli settentrionali e massime i più settentrionali sieno oggi i più caldi di spirito, i più immaginosi in fatto, i più mobili e governabili dalle illusioni, i più sentimentali e di carattere e di spirito e di costumi, i più poeti nelle azioni e nella vita, e negli scritti e letterature". 
Não obstante semelhante evidência parecer "singular e monstruosa" [singolare e mostruosa] ${ }^{311}$, trata-se de uma evidência, de algo que "salta aos olhos" [salta agli occhi] ${ }^{312}$, ou seja, de uma "verdade" [verità $]^{313}$. Nesse momento do Discorso, Leopardi se serve de um "exemplo" [esempio] ${ }^{314}$, reportando-se à Alemanha daquela época e, conforme afirma, "no fundo do setentrião" [nel fondo del setentrione $]^{315}$. Daí ele indagar:

[Como] manter e existir nos nossos tempos e em tanta dissipação de ilusões, a sociedade dos Irmãos Moravi ${ }^{316}$ e muitos outros estabelecimentos e costumes semelhantes fundamentados apenas sobre princípios e apenas sobre a força da opinião? E opiniões certamente não conforme a exata, seca e fria filosofia geométrico-moderna. $\mathrm{O}$ que direi do quakerismo ${ }^{317}$ que ainda dura? E de cem semelhantes coisas da

p. 82.

${ }^{311}$ Cf. LEOPARDI, Giacomo. Discorso sopra lo stato presente dei costumi deglitaliani,

312 Cf. LEOPARDI, Giacomo. Discorso sopra lo stato presente dei costumi degl'italiani, p. 81.

p. 81.

${ }^{313}$ Cf. LEOPARDI, Giacomo. Discorso sopra lo stato presente dei costumi degl'italiani,

${ }^{314}$ Cf. LEOPARDI, Giacomo. Discorso sopra lo stato presente dei costumi degl'italiani, p. 81.

${ }^{315}$ Cf. LEOPARDI, Giacomo. Discorso sopra lo stato presente dei costumi deglitaliani, p. 81.

${ }^{316}$ Cf. LEOPARDI, Giacomo. Discorso sopra lo stato presente dei costumi degl'italiani, p. 81:mantenere e sussistere a' tempi nostri e in tanto dissipamento d'illusioni, la società dei Fratelli Moravi e molti altri simili stabilimenti e costumi fondati sopra soli principii e sopra la sola forza dell'opinioni certo non conformi all'esatta, secca e fredda filosofia geometrica-moderna. Che dirò del quakerismo che ancora dura? e di cento simili cose d'Inghilterra, Germania, e degli altri popoli del Nord". Conforme o comentário de Roberto Melchiori, trata-se de um movimento evangélico que teve origem na Boemia do século XV, "graças às predicações de Jan Hus". Leopardi recordaria ainda a forma da comunidade e da autonomia política de tal movimento em seu Zibaldone di pensieri, fragmentos 3349 (03.09.1823) e 3865 (11.11.1823). Madame de Staël, por sua vez, atribuiria a existência dessa comunidade religiosa aos inícios do século XVIII na Germânia, e louvaria dela o seu entusiasmo religioso, assim como também a severidade nos costumes, em seu escrito La Germania (Cf. MELCHIORI, Roberto. Commento in: LEOPARDI, Giacomo. Discorso sopra lo stato presente dei costumi degl'italiani, p. 135). Sobre os irmãos Moravi, ver ainda LEOPARDI, Giacomo. Zibaldone di pensieri, fragmentos 3349 (03.09.1823) e 3865 (11.11.1823), pp. 2111, 2216.

317 Cf. LEOPARDI, Giacomo. Discorso sopra lo stato presente dei costumi degl'italiani, p. 81. De acordo com Melchiori, os Quakers são uma "importante seita nascida no interior do protestantismo inglês em meados do século XVII", expandindo-se posteriormente até a América do norte (Cf. MELCHIORI, Roberto. Commento in: LEOPARDI, Giacomo. Discorso sopra lo stato presente dei costumi degl'italiani, p. 135). 
Inglaterra, Alemanha, e de outros povos do norte ${ }^{318}$ [da Europa].

Se contrapostas semelhantes "práticas religiosas" [pratiche religiose] ou, quaisquer outras, a dos italianos, pois Leopardi tem já claro aquilo que ocorreu na Itália,

essas na Itália [...] são usos e hábitos, não costumes, e todos fazem pouco disso, nem se encontram mais na Itália verdadeiros fanáticos de nenhum gênero, apenas entre aqueles que por posição têm interesse na conservação desta ou daquela espécie de fanatismo ou de ilusão ${ }^{319}$.

Nesses confrontos das "práticas" italianas e daquelas das nações europeias, Leopardi apresenta ainda outros elementos na sua exposição que completarão, além da relação entre meridionais e setentrionais, a sua diagnose relativa a esse deslocamento no modo de vida das "nações civis" - quanto às disposições delas de responder às novas circunstâncias após a modernização -, destacando aquelas que não alcançaram outros fundamentos para uma moralidade ante as exigências do mundo moderno e a dissipações das antigas ilusões. Trata-se agora da relação entre antigos e modernos. Para Leopardi, tais

práticas dos setentrionais cheira totalmente a antigo, e nada de moderno, e parecem incompatíveis com os nossos tempos, e quase insiram antiguidade nesses tempos. E observe-se que essas práticas são em grande parte, e talvez as mais, de origem muito modernas, aliás, nascidas das modernas revoluções de opiniões e de política, e delas diariamente nascem semelhantes ${ }^{320}$.

${ }^{318}$ LEOPARDI, Giacomo. Discorso sopra lo stato presente dei costumi degl'italiani, p. 81: "mantenere e sussistere a' tempi nostri e in tanto dissipamento d'illusioni, la società dei Fratelli Moravi e molti altri simili stabilimenti e costumi fondati sopra soli principii e sopra la sola forza dell'opinioni? e opinioni certo non conformi all'esatta, secca e fredda filosofia geométricamoderna. Che dirò El quakerismo che ancora dura? e di cento simili cose d'Inghilterra, Germania, e degli altri popoli del nord".

${ }^{319}$ LEOPARDI, Giacomo. Discorso sopra lo stato presente dei costumi deglitaliani, p. 81: "perchè queste in Italia [...] sono usi e consuetudini, non costumi, e tutti se ne ridono, né si trovano più in Italia veri fanatici di nessun genere, appena tra quelli che per istato hanno interesse alla conservazione di questa o quella specie di fanatismo o d'illusioni".

${ }^{320}$ LEOPARDI, Giacomo. Discorso sopra lo stato presente dei costumi degl'italiani, p: "pratiche de' settentrionali sanno affatto di ântico, e niente di moderno, e paiono incompatibili co' tempi nostri, e quase innesti dell'antichità in esse tempi. E notisi che esse pratiche sono in gran parte, e forse le più, di origine moderníssima, anzi nate dalle moderne rivoluzioni di opinioni e di política, e giornalmente ne nascono delle simili". 
Leopardi sabe que esse argumento pode parecer "monstruoso e contraditório" [mostruosi e contradditorio] sem as considerações antes apresentadas. Ele defende então:

Os povos meridionais superaram todos os outros na imaginação e, portanto, em tudo, nos tempos antigos; e os setentrionais por causa da mesma imaginação superaram de longe os meridionais nos tempos modernos $^{321}$.

Ademais, nos "tempos antigos" [tempi antichi] ${ }^{322}$ - acrescenta Leopardi - "o estado das coisas e das opiniões raciocinadas favorecia tanto a imaginação quanto nos tempos modernos a desfavorece" ${ }^{323}$. Porém, algo favorecia aos meridionais.

Ao se reportar à vitalidade, nos tempos antigos, da imaginação nos meridionais, Leopardi expõe a diferença existente entre meridionais e setentrionais, pois

na prática a imaginação dos povos meridionais era tão mais ativa do que aquela dos setentrionais quanto é agora ao contrário, porque a frieza da realidade tem tanto mais força sobre as imaginações e sobre os caracteres quanto eles são mais vivos e mais calorosos $^{324}$.

Os novos tempos indicam assim um deslocamento quanto à imaginação, exigindo ainda para a sua compreensão certo paralelo entre antigos e

${ }^{321}$ LEOPARDI, Giacomo. Discorso sopra lo stato presente dei costumi degl'italiani, p. 82: "I popoli meridionali superarono tutti gli altri nella immaginazione e quindi in ogni cosa, a' tempi antichi; e i setentrionali per la stessa immaginazione superarono di gran lunga $\mathrm{i}$ meridionali a' tempi moderni".

${ }^{322}$ Para Francesco Tateo o antigo em Leopardi é "uma sensação, não um modelo [...], é um mito, mas não no sentido específico do termo, uma palavra que vive na realidade imediata de quem a pronuncia, mas para concretização de um modelo, é uma imaginação [...], para usar um vocábulo caro a Leopardi [...]"; (Cf. TATEO, Francesco. Leopardi e gli antichi. In: Michele Dell'Aquila (org.). Ripensare Leopardi. Fasano:Schena, 1999, p. 12; Sobre a questão dos antigos ver ainda os estudos de Timpanaro sobre a filolofia leopardiana: TIMPANARO, Sebastiano. La filologia di Giacomo Leopardi. Roma-Bari: Laterza\&Figli, 2008 (4ªed.).

${ }^{323}$ LEOPARDI, Giacomo. Discorso sopra lo stato presente dei costumi degl'italiani, pp. 82-83: "lo stato reale delle cose e delle opinioni ragionate favoriva tanto l'immaginazione quanto ai tempi moderni la sfavorisce".

${ }^{324}$ LEOPARDI, Giacomo. Discorso sopra lo stato presente dei costumi degl'italiani, p. 83: "in pratica l'immaginazione de' popoli meridionali era tanto più attiva de quella de' settentrionali quanto è ora al contrario, perchè la freddezza della realtà há tanta più forza sulle immaginazioni e sui caratteri quanto essi sono più vivi e più caldi”. 
modernos. Para Leopardi, as nações setentrionais e, sobretudo, o povo, certamente

são muito mais comparáveis e semelhantes hoje em dia às antigas que não são as nações, e de modo geral o povo do mezzogiorno, enquanto é mesmo certo que devendo escolher entre os climas e entre as características naturais dos povos uma imagem da antiguidade ninguém duvidaria de escolher os meridionais, e os setentrionais, ao contrário, como imagem do moderno ${ }^{325}$.

Com base nessas observações, Leopardi diz não duvidar de atribuir em grande parte no presente das nações civis desenvolvidas, a "superioridade visível" [visibile superiorità] ${ }^{326}$ dos setentrionais sobre os meridionais, na política, na literatura, em tudo ${ }^{327}$, por causa da superioridade da "imaginação" [immaginazione] dos setentrionais ${ }^{328}$. Para ele, isso não decorre de "coisas acidentais" [cose accidentali], uma vez que parece que "o tempo do setentrião tenha chegado" 329 , pois até então havia "brilhado e podido no mundo o mezzogiorno" 330 . Se os meridionais foram feitos para "brilhar e preponderar" [brillare e prepotere] ${ }^{331}$ em tempos como aqueles antigos, os setentrionais, ao contrário, são feitos justamente "para se manter a superioridade nos tempos da natureza dos modernos" ${ }^{332}$.

${ }^{325}$ LEOPARDI, Giacomo. Discorso sopra lo stato presente dei costumi degl'italiani, p. 83: "sono molto più paragonabili e simili oggidì ale antiche che non sono le nazioni, e massime il popolo, del mezzogiorno, laddove è pur certo che dovendo sceglier tra i climi e tra i caratteri naturali dei popoli uma immagine dell'antichità niuno dubiterebbe di scegliere i meridionali, e i settentrionali viceversa per immagini del moderno". p. 83.

${ }^{326}$ Cf. LEOPARDI, Giacomo. Discorso sopra lo stato presente dei costumi deglitaliani,

${ }^{327}$ Cf. LEOPARDI, Giacomo. Discorso sopra lo stato presente dei costumi degl'italiani, p. 83. p. 83.

${ }^{328}$ Cf. LEOPARDI, Giacomo. Discorso sopra lo stato presente dei costumi degl'italiani,

${ }^{329}$ LEOPARDI, Giacomo. Discorso sopra lo stato presente dei costumi degl'italiani, p. 83: "il tempo del settentrione sia venuto".

${ }^{330}$ LEOPARDI, Giacomo. Discorso sopra lo stato presente dei costumi degl'italiani, p. 83: "brillato e potuto nel mondo il mezzogiorno". p. 83.

${ }^{331}$ Cf. LEOPARDI, Giacomo. Discorso sopra lo stato presente dei costumi degl'italiani,

332 LEOPARDI, Giacomo. Discorso sopra lo stato presente dei costumi degl'italiani, p. 83: "per tenere il disopra ne' tempi della natura de' moderni". 
Em tais argumentos, Leopardi concebe a "natureza e disposição dos tempos modernos" [natura e disposizione de' tempi moderni] como não acidentais, uma vez que não passageiras, justificando, por sua vez, "a superioridade do setentrião" [la superiorità del settentrione], também como não "acidental" [accidentale] e sequer "previsível" [prevedibile]. Segue-se daí a seguinte observação leopardiana:

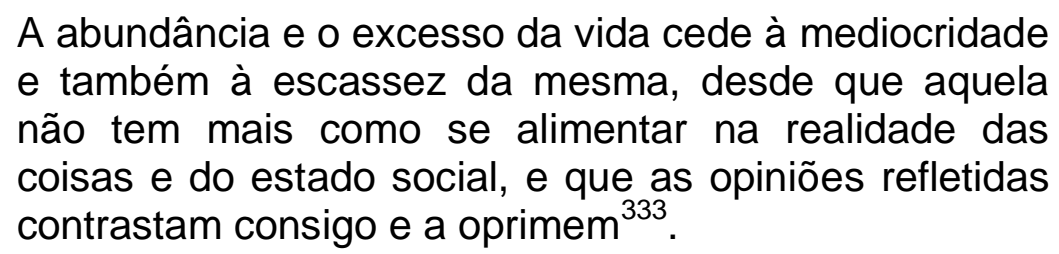

Em uma nota leopardiana, presente no Discorso de 1824, há o argumento de que as "histórias" [istorie] demonstram algo sobre os "povos superiores aos outros nas grandes ilusões" [popoli superiori agli altri nelle grandi illusioni]. Tais povos seriam superiores também em tudo, a saber, "na literatura, na felicidade, riqueza e indústria nacional, na preponderância e domínio direto ou indireto sobre os outros" ${ }^{334}$. Aqui Leopardi se reporta, de novo, à "situação" [situazione] de alguns povos setentrionais, pois esses povos conservam, no seu entender, a "imaginação em meio à crescente civilização" [immaginazione in mezzo alla crescente civiltà] ${ }^{335}$. Não se trata, porém, de sua inexistência nos "baixos tempos" [bassi tempi], pois a imaginação esteve "unida à barbárie" [congiunta alla barbarie] ${ }^{336}$. Já nos "modernos" [moderni], sobretudo no Mezzogiorno, Leopardi assegura não faltar "civilização" [civiltà], mas decerto "a imaginação posta em atividade" [l'immaginazione posta in attività] ${ }^{337}$.

333 LEOPARDI, Giacomo. Discorso sopra lo stato presente dei costumi degl'italiani, p. 83: "L'abbondanza e l'eccesso della vita cede alla mediocrità ed anche alla scarsezza della medesima, da poi che quella non ha più come alimentarsi nella realtà delle cose e dello stato sociale, e che le opinioni ragionate contrastano seco e l'opprimono".

334 LEOPARDI, Giacomo. Discorso sopra lo stato presente dei costumi degl'italiani, pp. 83-84: "nella letteratura, nella felicita, ricchezza e industria nazionale, nella preponderanza e domínio diretto o indiretto sopra gli altri”.

p. 84.

${ }^{335}$ Cf. LEOPARDI, Giacomo. Discorso sopra lo stato presente dei costumi degl'italiani, p. 84.

${ }^{336}$ Cf. LEOPARDI, Giacomo. Discorso sopra lo stato presente dei costumi degl'italiani,

${ }^{337}$ Cf. LEOPARDI, Giacomo. Discorso sopra lo stato presente dei costumi degl'italiani, p. 84. 
Em oposição tanto ao mundo medieval, no qual a imaginação se encontrava unida à "barbárie" [barbarie $]^{338}$, como no moderno, em que se revela a imaginação sem "atividade" [attività] ${ }^{339}$-, embora o Discorso não fale da barbárie dos novos tempos, mas já anuncie certos elementos que podem indicar novos riscos - os dois estados são contrários - conforme Leopardi argumenta - "à grandeza e superioridade nacional" [alla grandezza e superiorità nazionale $]^{340}$. Ele conclui esse argumento, defendendo a união entre "civilização" [civiltà] e "imaginação" [immaginazione], como a do "estado dos antigos, e justamente o estado antigo, e não é oportuno dizer de qual grandeza eles fossem causa" ${ }^{341}$.

Leopardi conclui o Discorso com uma constatação relativa à natureza dos meridionais, a qual justifica igualmente as mudanças ocorridas - tanto na relação com as nações setentrionais, como no deslocamento realizado nas disposições naturais e culturais dos meridionais para os setentrionais: algo que justifica a natureza dos meridionais, quer na antiga superioridade quer na perda dela. No seu entender:

Como a vida e a força interior e do espírito são naturalmente maiores nos meridionais, e nos indivíduos sensíveis e nos finos engenhos, do que o são nos outros, por isso eles são nas ações deles e no caráter deles mais determinados e governados, por assim dizer, pelo ânimo, e menos mecânica que outros povos e indivíduos. Portanto é quando os princípios e as persuasões deles são contrárias às ilusões, frias, tendentes à indiferença, à aridez, ao puro cálculo, também os caracteres e as ações deles são no todo e constantemente frias, calculadas, indiferentes, insensíveis, muito mais que nos outros povos e indivíduos também mais instruídos, mais filósofos, mais fundamentados e providos de princípios contrários às

\footnotetext{
${ }^{338}$ Cf. LEOPARDI, Giacomo. Discorso sopra lo stato presente dei costumi degl'italiani, p. 84 .

${ }^{339}$ Cf. LEOPARDI, Giacomo. Discorso sopra lo stato presente dei costumi degl'italiani, p. 84. p. 84 .

${ }^{340}$ Cf. LEOPARDI, Giacomo. Discorso sopra lo stato presente dei costumi deglitaliani,

${ }^{341}$ LEOPARDI, Giacomo. Discorso sopra lo stato presente dei costumi degl'italiani, p. 84: "stato degli antichi, e propriamente lo stato ântico, e non accade dire di qual grandezza ei fosse cagione".
} 
ilusões e ao imaginativo, e tendente à frieza, indiferença, insensibilidade ${ }^{342}$.

Isso ocorre porque, conforme Leopardi argumenta, a "correspondência" [corrispondenza] entre os "princípios [principi] e a "prática" [pratica] é bem mais constante nos meridionais do que em qualquer outro povo" 343 .

\subsection{Clima e disposições naturais: setentrionais e meridionais}

A indagação leopardiana, realizada no Discorso de 1824 sobre as causas do atraso italiano ante as outras nações civis europeias, exige aqui ainda um excurso no Zibaldone di pensieri, pois o Discorso tem a sua elaboração em um momento relevante de reflexão do Zibaldone ${ }^{344}$. Ademais, não obstante as diferenças de abordagem do tema nessas obras, algo defendido por alguns estudiosos ${ }^{345}$, agora importa acrescentar novos elementos ou aprofundar aqueles já anunciados no Discorso. Daí a necessidade de se enfrentar, de início, a questão da natureza e do clima, de acordo com alguns fragmentos do Zibaldone.

Ao refletir ainda sobre a problemática da relação entre os povos, Leopardi no Zibaldone argumenta acerca do clima e da natureza dos povos. Nesse sentido ele defende que a "estação e o clima frio dá mais força de agir, e menos vontade de fazê-lo, maior contentamento do presente, inclinação para a ordem, para o método, e até para a uniformidade" ${ }^{346}$. Isto porque o calor, no

342 LEOPARDI, Giacomo. Discorso sopra lo stato presente dei costumi degl'italiani, p. 84: “Come la vita e la forza interna e dello spirito è naturalmente maggiore ne' meridionali, e negl'individui sensibili e ne' fini ingegni, che non è negli altri, perciò essi sono nelle loro azioni e nel loro carattere più determinati e governati, per dir cosi, dall'animo, e meno macchinali che gli altri popoli e individui. Quindi è che quando i principii e le persuasioni loro sono contrarie alle illusioni, fredde, conducenti all'indiferenza, all'aridità, al puro calcolo, anche i caratteri e le azioni loro sono al tutto e constantemente fredde, calcolate, indifferenti, insensibili, più assai che negli altri popoli e individui anche più intruiti, più filosofi, più fondati e provveduti di principii contrarii alle illusioni e all'immaginoso, e conducenti alla freddezza, indifferenza, insensibilitài". p. 84.

${ }^{343}$ Cf. LEOPARDI, Giacomo. Discorso sopra lo stato presente dei costumi degl'italiani,

344 Cf. PLACANICA, Augusto. Leopardi e il Mezzogiorno del mondo, p. 48.

345 Ver nota 3.

${ }^{346}$ Cf. LEOPARDI, Giacomo. Zibaldone di pensieri, fragmento 3347, 03.09.1823, in: Tutte le poesie, tutte le prose e lo Zibaldone, p. 2111: "La stagione e il clima freddo dà maggiore forza di agire, e minor voglia di farlo, maggior contentezza del presente, inclinazione all'ordine, al metodo, e fino all'uniformità". 
seu entender, diminui nos ânimos "as forças do agir, e ao mesmo tempo [neles] inspira e inflama o desejo delas, [os] torna muito suscetíve[is] de tédio, intolerantes com a uniformidade da vida, vagos de novidades, descontentes de si mesmos e com o presente" ${ }^{347}$. Contrapondo os dois climas às disposições do ânimo, Leopardi diz parecer que "o frio fortifique o corpo e una o ânimo: que o calor adormeça, quer excitando quer despertando, quer derretendo o ânimo" ${ }^{348}$.

Certamente esses argumentos de Leopardi preparam e integram as suas análises da natureza dos povos setentrionais e meridionais. Quando aborda a atividade do corpo e do ânimo de ambos os povos, ele escreve que a "atividade do corpo é própria dos setentrionais, dos meridionais aquela do ânimo"349. Ele sabe, porém, que o corpo não opera se não é movido pelo ânimo ${ }^{350}$, mas pretende explicitar o que prevalece na natureza desses povos, não obstante parecer paradoxal.

Portanto, é que os setentrionais, ainda que sem controvérsia seja justamente deles a atividade e laboriosidade, mesmo sendo realmente os povos mais quietos da terra e os meridionais os mais inquietos, embora seja propriedade deles a indolência ${ }^{351}$.

Comparando ainda a tendência natural desses povos na vida civil, Leopardi reconhece nos setentrionais a necessidade de um forte "impulso" [stimulo] para se movimentar e sublevar, enfim, para "buscar novidades" [cercar novità], mas quando impelidos torna-se difícil acalmá-los ${ }^{352}$. Nas histórias

347 Ibidem: "le forze di agire, e nel tempo stesso ne ispira ed infiamma il desiderio, rende suscetibililissimi della noia, intolleranti dell'uniformità della vita, vaghi di novità, malcontenti di se stessi e del presente".

348 Ibidem: "il freddo fortifichi il corpo e leghi l'animo: che il caldo addormenti e ammolisca e illanguidisca e intorpidisca il corpo, eccitando e svegliando e sciogliendo l'annimo". Sobre o ambiente geografico e o clima, ver ainda a reflexão de Chabod sobre a "ideia de nação": CHABOD, Federico. L'idea di nazione. p. 30-31. dell'animo".

349 Ibidem: 'L'attività del corpo è própria dei settentrionali, de' meridionali quella

350 Cf. LEOPARDI, Giacomo. Zibaldone di pensieri, fragmento 3347, 03.09.1823, in: Tutte le poesie, tutte le prose e lo Zibaldone, p. 2111.

${ }^{351}$ LEOPARDI, Giacomo. Zibaldone di pensieri, fragmento 3347, 03.09.1823, in: Tutte le poesie, tutte le prose e lo Zibaldone, p. 2111: "Quindi è che i settentrionali, sebbene senza controversia sia lor propria l'attività e laboriosità, pur sono veramente i più quieti popoli della terra e i meridionali i più inquieti, benché sai loro propria l'infingardaggine".

352 Cf. LEOPARDI, Giacomo. Zibaldone di pensieri, fragmento 3347, 03.09.1823, in: Tutte le poesie, tutte le prose e lo Zibaldone, p. 2111. 
desses povos, segundo Leopardi expõe, de modo geral nas modernas, vê-se, sobretudo,

naquelas da Alemanha pouquíssimas revoluções [...] (em especial se comparada com aquelas dos meridionais), mas essas muito longas, como aquela de religião dirigida por Lutero, e convertida bem logo em revolução política 353 .

Ademais, os setentrionais suportam, como Leopardi comenta,

facilmente a tirania, até que ela não os impelem à bout, como os suíços. Obedecem de boa vontade, e comandados sofrem (também excessivamente) mais de boa vontade do que se operassem espontaneamente. Vê-se na milícia deles ${ }^{354}$.

Quanto aos meridionais, Leopardi identifica neles disposições naturais contrárias àquelas dos setentrionais, pois são

propensos e preparados e frequentes em se mexer, revoltosos, pouco tolerantes com a tirania, pouco amigos do obedecer, mas muito fáceis ainda para sossegar, muito fáceis para retornar ao repouso; inconstantes, volúveis, instáveis, desejosos de novidades políticas, incapazes de mantê-las, sequiosos de liberdade, incapazes de conservá-la ${ }^{355}$.

Os setentrionais, por sua vez, raramente a buscam, cuidam pouco dela, mas quando procurada e conseguida, eles a conservam por longo tempo. Para Leopardi, os setentrionais, em especial, os alemães e teutônicos são

os únicos na Europa que conservam algum vestígio de liberdade, alguma imagem das antigas Repúblicas; os únicos junto aos quais as repúblicas se vêem por experiência poder durar também nos tempos modernos $^{356}$.

353 LEOPARDI, Giacomo. Zibaldone di pensieri, fragmento 3347, 03.09.1823, in: Tutte le poesie, tutte le prose e lo Zibaldone, p. 2111: "in quelle della Germania pochissime rivoluzioni, [...] (specialmente a paragone di quelle de' meridionali), ma queste lunghissime, come quella di religione mossa da Lutero, e convertita ben tosto in rivoluzione política".

354 Ibidem: "facilmente la tirannia, finch'ella non gli spinge à bout, come gli Svizzeri. Ubbidiscono volentieri, e comandati travagliano (anche eccessivamente) più volentieri che se operassero spontaneamente. Vedesi nella loro milizia".

355 LEOPARDI, Giacomo. Zibaldone di pensieri, fragmento 3348, 03.09.1823, in: Tutte le poesie, tutte le prose e lo Zibaldone, p. 2111: "facili e pronti e frequenti a muoversi, rivoltosi, poco tolleranti della tirannide, poco amici dell'ubbidire, ma facilissimi ancora a racquietare, facilissimi a ritornare in riposo; mobili, volubili, instabili, vaghi di libertà, incapaci di conservarla".

${ }^{356}$ Cf. LEOPARDI, Giacomo. Zibaldone di pensieri, fragmentos 3348-3349, 03.09.1823, in: Tutte le poesie, tutte le prose e lo Zibaldone, p. 2111: "i soli in Europa che serbino qualche vestígio di liberta, qualche immagine della antiche Repubbliche; i soli appo cui le repubbliche si veggano per esperienza Poter durare anche a' tempi moderni". 
Como exemplo, Leopardi indica os suíços e as cidades livres da Alemanha ${ }^{357}$.

Ao pensar nas disposições naturais dos setentrionais, Leopardi estabeleceu uma diferença entre antigos e modernos no que concerne ao "caráter" [carattere] e ao "costume" [costume], ou seja, os "antigos setentrionais e habitantes dos países frios, e aqueles dos modernos; diferença maior que aquela que costuma se encontrar geralmente desde os antigos aos modernos" ${ }^{\prime 35}$. Os antigos setentrionais são descritos pelos historiadores, segundo Leopardi,

como muito ferozes, muito inquietos não somente de caráter, mas de fato, [...] sempre desejosos de novidade, sempre mecânicos, sempre teimosos e revoltados e como quase absolutamente indomáveis e bravos. Alemães, citas etc ${ }^{359}$.

Já os modernos setentrionais revelam outras características, opostas às dos antigos, pois se apresentam tão "domáveis" [domabili]: algo que nenhum povo meridional é tanto. Distantes de toda ferocidade, não há povo melhor, mais manso, mais obediente, mais tolerante que os setentrionais modernos. Se existe uma parte da Europa, de acordo com Leopardi, em que "menos se trame, e se revolte perante o comando, e se deseje novidade e se odeie a sujeição, isso está exatamente entre os povos setentrionais" ${ }^{360}$. Segundo Leopardi, algo contribuiu para essas consequências: de um lado "a diversidade dos governos antigos e modernos e, de outro, o pouco cultivo do povo nas

${ }^{357}$ Cf. LEOPARDI, Giacomo. Zibaldone di pensieri, fragmento 3347, 03.09.1823, in: Tutte le poesie, tutte le prose e lo Zibaldone, p. 2111.

358 Cf. LEOPARDI, Giacomo. Zibaldone di pensieri, fragmento 3676, 13.10.1823, in: Tutte le poesie, tutte le prose e lo Zibaldone, p. 2173: "antichi settentrionali e abitatori de' paesi freddi, e quel de' moderni; differenza maggior di quella che suol trovarsi generalmente dagli antichi ai moderni".

359 Ibidem: "per ferocissimi, inquietissimi, attivissimi non solo di carattere, ma di fatto, [...] sempre vaghi di novità, sempre macchinanti, sempre recalcitranti e insorgenti e per quase assolutamente indomabili e indomiti. Germanici, Sciti ecc.".

360 Ibidem: "meno si macchini, e si ricalcitri al comando, e si desideri novità e si odii la soggezione, cio è per l'appunto fra i popoli settentrionali”. 
regiões setentrionais" ${ }^{361}$. Ele não desconsidera também "a diferença material da vida" [la differenza materiale della vita] ${ }^{362}$.

Leopardi observa, na formação desses povos e das características particulares de ambos, a articulação entre os elementos climáticos e as contradições "materiais da vida" [materiali della vita] ${ }^{363}$. Ele escreve, reportando-se aos antigos setentrionais, que

mal abrigados contra as inclemências do clima pelos casebres, procurando-se alimento com a caça [...] tinham também mais úmaí日 hoje em dia os meridionais. Introduzidos os usos e comodidades os povos civilizados do Norte se tornaram naturalmente os mais caseiros da terra ${ }^{364}$.

Tal condição propicia, assevera Leopardi, tanto a "nações" [nazioni] quanto a "indivíduos" [individui], sossego e calma, mas nada os torna menos "cobiçosos" [cupidi] e mais "inimigos da novidade" [nemici della novità] do que a vida caseira $^{365}$. Os "hábitos domésticos" [abitudini domestiche] terminam afeiçoando ao método, tornando, com efeito, nações e indivíduos, mais contentes com o presente ${ }^{366}$.

Certamente que as análises leopardianas sobre o clima, as disposições, o modo de vida das nações e os indivíduos preparam, ao mesmo tempo, as suas conclusões no sentido da filosofia moral. Ele argumenta ainda no Zibaldone di pensieri - conforme os fragmentos 4062-4064 - que quando se considera

essas condições físicas da vida com relação ao moral, pode-se racionalmente afirmar que a sorte daqueles

${ }^{361}$ Ibidem: "la diversità de' governi antico e moderno, dall'altro la poco coltura del popolo nelle regioni settentrionali".

${ }^{362}$ Cf. LEOPARDI, Giacomo. Zibaldone di pensieri, fragmento 3676, 13.10.1823, in: Tutte le poesie, tutte le prose e lo Zibaldone, p. 2173.

${ }^{363}$ Cf. LEOPARDI, Giacomo. Zibaldone di pensieri, fragmento 3676, 13.10.1823, in: Tutte le poesie, tutte le prose e lo Zibaldone, p. 2173.

${ }^{364}$ LEOPARDI, Giacomo. Zibaldone di pensieri, fragmento 3676, 13.10.1823, in: Tutte le poesie, tutte le prose e lo Zibaldone, p. 2173: "mal difesi contro le inclemenze dell'aria dalle spelonche, proccurantesi il vitto colla caccia [...] erano anche più úmaí $\theta \rho ı$ di vita, che non sono i meridionali oggidì. Introdotti gli usi e i comodi sociali, i popoli civilizzati del Nord divennero naturalmente i più casalinghi della terra".

${ }^{365}$ Cf. LEOPARDI, Giacomo. Zibaldone di pensieri, fragmento 3676, 13.10.1823, in: Tutte le poesie, tutte le prose e lo Zibaldone, p. 2173.

${ }^{366}$ Cf. LEOPARDI, Giacomo. Zibaldone di pensieri, fragmento 3676, 13.10.1823, in: Tutte le poesie, tutte le prose e lo Zibaldone, p. 2173. 
que vivem nos países bastante quentes é preferível quanto à felicidade aquela dos outros povos. [...] A vida não tem absolutamente nada de desejável de maneira que a mais longa seja preferível. Preferível é a menos infeliz, e a menos infeliz é a mais viva [...]. Ora essa comparação de climas eu a aplico aos tempos, e pondo os antigos no lugar dos povos de clima quente e os modernos, no lugar dos povos de clima frio, digo que embora a vida dos antigos fosse talvez, geralmente mais breve do que aquela dos modernos, pelas turbulências sociais e os contínuos perigos do estado antigo, apesar de tudo porque muito mais intensa, ela é preferível, contendo na sua menor duração maior soma de vitalidade, ou quando também em menor espaço contivesse igual soma que a moderna maior em espaço ${ }^{367}$.

\subsection{Meridionais-setentrionais e Antigos-modernos: sobre a atividade da imaginação, a filosofia e a vida civil}

As considerações de Leopardi sobre a influência do clima nas disposições naturais e no modo de vida dos povos e indivíduos justificaram certa orientação que ultrapassa unilateralidades na reflexão e compreensão da natureza de certas nações civis, em particular, na Modernidade, mesmo que ele não deixe de se reportar aos Antigos. Ainda no Zibaldone di pensieri, refletindo sobre a natureza desses povos e suas particularidades, Leopardi defende que no seu procedimento não trata das "circusntâncias" [circostanze] como "passageiras e acidentais" [passegere e accidental], ou seja, "como a maior ou mais divulgada e comum cultura de espírito etc., mas naturalmente e

${ }^{367}$ Cf. LEOPARDI, Giacomo. Zibaldone di pensieri, fragmento 4062-4064, 08.04.1824, in: Tutte le poesie, tutte le prose e lo Zibaldone, pp. 2273-2274: "queste condizioni fisiche della vita per rapporto al morale, si può ragionevolmente affermare che la sorte di quelli che vivono ne' paesi assai caldi è preferibile quanto alla felicita a quella degli altri popoli. [...] La vita assolutamente non ha nulla di desiderabile sicchè la più lunga sia da preferirsi. Da preferirsi è la meno infelice e la meno infelice è la più viva. [...] Or questo paragone di climi io lo applico ai tempi, e mettendo gli antichi in luogo de' popoli di clima caldo e i moderni in cambio de' popoli di clima freddo, dico che sebben la vita degli antichi era forse generalmente più breve che quella dei moderni, per le turbolenze sociali e i continui pericoli dello stato antico, nondimeno perchè molto più intensa, ella è da preferirsi, contenendo nella sua minore durata maggior somma di vitalità, o quando anche in minore spazio contenesse ugual somma che la moderna in ispazio maggiore". 
constantemente, no sistema de vida social” ${ }^{368}$. Tornando-se a civilização comum no norte e no sul, assevera Leopardi,

os povos do mezzogiorno, como menos caseiros, tenham sido, sejam e tenham quer ser mais inquietos e mais ativos que aqueles do setentrião, tanto no ânimo, como na realidade, ao contrário daquilo que levaria a pura natureza de uns e de outros, comparativamente considerada ${ }^{369}$.

É preciso se considerar outras causas, a fim de uma compreensão das mudanças ocorridas no modo de ser desses povos, uma vez que Leopardi reconhece ser "os setentrionais modernos e civis [...] na verdade muito mais diversos e mudados que os seus antigos, que não são os meridionais dos antigos deles; tanto no caráter, [...] nos usos, [...] nas ações etc." ${ }^{370}$.

Leopardi retoma assim, em seguida, a disposição setentrional da "vida caseira" [vita casalinga] para interpretar certas disposições e atividades dos setentrionais na vida civil. Isso porque a

vida caseira, metódica e uniforme [...] contribui para por em atividade a imaginação, a despertar e apascentar as ilusões, e faz que o homem, transborde de imaginação e delírios, com esses facilmente faz menos obras, e baste a si mesmo, e encontre prazer em si mesmo, acrescendo a vida e a ação interna com prejuízo para a externa; bem mais do que fazem a beleza e a vitalidade da natureza nos países meridionais $^{371}$.

Em tais países, ou seja, dos meridionais, Leopardi reconhece que

${ }^{368}$ LEOPARDI, Giacomo. Zibaldone di pensieri, fragmento $3676,13.10 .1823$, in: Tutte le poesie, tutte le prose e lo Zibaldone, p. 2173: "come la maggiore o più divulgata e comune coltura di spirito ecc. Ma naturalmente e costantemente, nel sistema di vita sociale".

369 LEOPARDI, Giacomo. Zibaldone di pensieri, fragmento 3676-3677, 13.10.1823, in: Tutte le poesie, tutte le prose e lo Zibaldone, p. 2173: "i popoli del mezzogiorno, come meno casalinghi, sieno stati, sieno ed abbiano a essere più inquieti e più attivi di quelli del settentrione, si d'animo, si di fatti, al contrario di quello che porterebbe la pura natura degli uni e degli altri comparativamente considerata".

${ }^{370}$ LEOPARDI, Giacomo. Zibaldone di pensieri, fragmento $3678,13.10 .1823$, in: Tutte le poesie, tutte le prose e lo Zibaldone, p. 2173: "i settentrionali moderni e civili [...] in verità molto più diversi e mutati da' loro antichi, che non sono i meridionali dagli antichi loro; si di carattere, si di usi, di azioni ecc.".

${ }^{371}$ LEOPARDI, Giacomo. Zibaldone di pensieri, fragmento 3678, 13.10.1823, in: Tutte le poesie, tutte le prose e lo Zibaldone, p. 2173: "vita casalinga metódica e uniforme, [...] contribuisce a mettere in attività l'immaginazione, a destare e pascere le illusioni, e fa che l'uomo abbondi d'immagini e di deliri, e con questi facilmente faccia di meno delle opere, e basti a se stesso, e trovi piaceri in se stesso, ad accrescere la vita e l'azione interna in pregiudizio dell'esterna; assai più che non fanno la bellezza e la vitalità della natura ne' paesi meridionali". 
os homens são distraídos e dissolutos, e voltados para o exterior, e têm sempre sob os olhos o mundo e os outros homens, quer a vida, quer a sociedade, quer a realidade das coisas; o que destrói ou impede a imaginação e a ilusão, e produz o tédio, e, portanto, o descontentamento do presente e o desejo de novidade ${ }^{372}$.

Leopardi se reporta aqui ao desenvolvimento nos setentrionais de certas disposições, faculdades e atividades voltadas para a "cultura do espírito" ${ }^{\text {"73 }}$, como forma distinta do que ocorre com os meridionais. Nesse sentido ele explicita, tendo como base a "vida caseira" [vita casalinga ${ }^{374}$ dos setentrionais, outras disposições que contribuem, quer para uma natureza distinta quer para certas atividades do espírito. Por isso,

a solidão, o estar sempre, ou a maior parte do tempo, recolhido em si mesmo, o estar desprovido ou escasso de distrações, por causa do método e da uniformidade da vida e da pouca sociedade, deixa livre o campo às faculdades da alma de agir, de se desenvolver, de curvar-se sobre si mesmas, de meditar, de pensar, de refletir, de imaginar e produzir necessariamente um hábito de pensamento, que prejudica sumamente, ou também exclui, quer o hábito quer a inclinação, quer o ato do operar ${ }^{375}$.

Em verdade, a formação e o desenvolvimento de certas faculdades e atividades decorrem de modos de ser específicos, e quando se trata de faculdades voltadas para o pensamento e reflexão, Leopardi sabe que outro é o modo de povos e indivíduos se constituírem. Isso explica porque:

estar grande parte do tempo distante do mundo, da sociedade, dos homens de fora; o hábito de ver a vida

372 Ibidem: "gli uomini sono distratti e dissipati, e versati al di fuori, ed hanno sempre sotto gli occhi il mondo e gli altri uomini, e la vita e la società e la realtà delle cose; il che distrugge o impedisce l'immaginazione e l'illusione, e produce la noia, e quindi la scontentezza del presente e il desiderio di novità".

${ }^{373}$ Cf. LEOPARDI, Giacomo. Zibaldone di pensieri, fragmento 3677, 13.10.1823, in: Tutte le poesie, tutte le prose e lo Zibaldone, p. 2173.

${ }^{374}$ Cf. LEOPARDI, Giacomo. Zibaldone di pensieri, fragmento 3678, 13.10.1823, in: Tutte le poesie, tutte le prose e lo Zibaldone, p. 2173.

${ }^{375}$ LEOPARDI, Giacomo. Zibaldone di pensieri, fragmento 3679, 13.10.1823, in: Tutte le poesie, tutte le prose e lo Zibaldone, p. 2173: "la solitudine, l'esser sempre, o il più del tempo, raccolto in se stesso, l'esser privo o scarso di distrazioni, stante il método e l'uniformità della vita e la poca società, lascia libero il campo alle facoltà dell'anima di agire, di svilupparsi, di ripiegarsi sopra se stesse, di meditare, di pensare, di riflettere, d'immaginare, e produce necessariamente un'abitudine di pensiero, che nuoce sommamente, o anche esclude, si l'abito si l'inclinazione, si l'atto dell'operare". 
e as coisas humanas ordinariamente de longe, produz naturalmente as ilusões e os belos sonhos e os castelos de areia, e deixa livre o imaginar e o representar-se, [...] o criar-se o mundo [...] os homens [...] a vida a seu modo, e dá lugar à esperança ${ }^{376}$.

Já a esperança, quando perdida, esses homens setentrionais a recuperam

(porque a esperança, desde que seja deixada a agir, e não seja rejeitada pela realidade, por causa da natureza do homem, retorna indubitavelmente e logo retorna); ou debilitada, Ihe dá tempo de se restaurar e se reintegrar; ou agonizante, a conserva, pelo menos em vida; ou faz, enfim, que em igualdade de circunstâncias, ela seja sempre mais do que não seria em uma vida em meio ao mundo; e mantém longe, ou adia ou diminui o desengano, ou debilita os efeitos dela, ou reduz a extensão dela etc. ${ }^{377}$

Dessas observações, Leopardi infere "consequência e prova" [conseguenza e prova] de que os setentrionais são, por uma parte,

mais profundos e subtis especuladores, mais filósofos, sobretudo nas ciências abstratas, ou partes mais abstratas dessas, ou gêneros mais abstratos etc., em suma, mais pensadores que os meridionais; daí Staël chamar a Alemanha la patrie de la pensée ${ }^{378}$.

Por outra, e algo que pode até parecer contrário, conforme Leopardi, seja por essa qualidade seja pela natureza dos setentrionais e meridionais, os primeiros

são mais imaginosos e realmente mais poetas e mais entusiastas sensíveis, e de fantasia mais eficaz e forte (quanto, porém, ao poetar, não quanto ao agir; e quanto ao que é obra apenas do espírito, não do

${ }^{376}$ Ibidem: "l'esser gran parte del tempo, lontano dal mondo, dalla società, dagli uomini d fuori; l'abitudine di veder la vita e le cose umane ordinariamente da lungi, produce naturalmente le illusioni e i bei sogni e i castelli in ária, e lascia libero l'immaginare e il figurarsi, e il crearsi il mondo e gli uomini e la vita a suo modo, e dà luogo alla speranza".

${ }^{377}$ LEOPARDI, Giacomo. Zibaldone di pensieri, fragmento 3679-3680, 13.10.1823, in: Tutte le poesie, tutte le prose e lo Zibaldone, pp. 2173-2174: "(perchè la speranza, purché sia lasciata fare, e non sai continuamente respinta dalla realtà, per natura dell'uomo indubitamente e presto ritorna); o indebolita, le dà agio di ristorarsi e rintegrarsi; o moribonda, la conserva, se non altro in vita; o fa insomma, che in parità di circostanze, ella sai sempre maggiore che non sarebbe in una vita in mezzo al mondo; e tien lungi, o ritarda o minora il disinganno, o ne indebolisce gli effetti, o ne restringe l'estensione ecc.".

${ }^{378}$ LEOPARDI, Giacomo. Zibaldone di pensieri, fragmento $3680,13.10 .1823$, in: Tutte le poesie, tutte le prose e lo Zibaldone, p. 2174: "più profondi e sottili speculatori, più filosofi, massime nelle scienze astratte, o parti più astratte di esse, o generi più astratti ecc., e insomma più pensatori che i meridionali; onde la Staël chiama la Germania la patrie de la pensée". 
corpo), e mais inventivos, originais e fecundos do que são os meridionais ${ }^{379}$.

Leopardi defende, porém, ser realmente, tal "superioridade" [superiorità] dos setentrionais modernos, um entre tantos outros "acidentes sociais" [accidente social], mas que não decorre necessariamente da natureza. Por isso, ele argumenta que semelhantes "acidentes" pertencem àqueles que são "constantes e conaturais, em absoluto, à essência da civilização, e que durando a civilização junto a uns e junto a outros povos, não podem nunca faltar"380. Certamente há aqui uma diferença dos argumentos apresentados no Discorso de 1824, de não ser a "imaginação" um privilégio apenas dos meridionais e da superioridade moderna dos setentrionais, se agora Leopardi defende ser um dos "tantos acidentes sociais" [tanti accidenti sociall], ao pensar o modo da existência setentrional. No seu Discorso, ele defendia, porém, não duvidar

de atribuir em grande parte a firme e visível superioridade presente das nações setentrionais sobre as meridionais, quer na política quer na literatura, quer em tudo que existe, à superioridade da imaginação deles. Nem esta nem aquela, consequentemente há de se considerar como coisas acidentais ${ }^{381}$.

Se aqui se retoma a concepção, apresentada por Leopardi no Zibaldone di pensieri sobre a imaginação e a relação setentrionais-meridionais, torna-se ainda mais evidente essa diferença, pois Leopardi, pensando a relação setentrionais-meridionais com base na "imaginação", sustenta:

Aliás, a imaginação dos setentrionais com respeito à meridional tanto é, geralmente e como em um todo,

379 Ibidem: "sono più immaginosi e più poeti veramente e più sensibili entusiasti, e di fantasia più efficace e forte (quantoperò al poetare non quanto all'operare; e quanto a cio ch'è opera del solo spirito, non del corpo), e più inventivi originali e fecondi che non sono $i$ meridionali".

${ }^{380}$ LEOPARDI, Giacomo. Zibaldone di pensieri, fragmento 3681, 13.10.1823, in: Tutte le poesie, tutte le prose e lo Zibaldone, p. 2174: "costanti e conaturali all'essenza della civiltà assolutamente, e che durando la civiltà appo gli uni e appo gli altri popoli, non possono venir meno".

${ }^{381}$ LEOPARDI, Giacomo. Discorso sopra lo stato presente dei costumi degl'italiani, p. 83: "di attribuire in gran parte la decisa e visibile superiorità presente delle nazioni settentrinali sulle meridionali, sì in política, sì in letteratura, si in ogni cosa, alla superiorità della loro immaginazione. Né questa, né quella per conseguenza, sono da considerarsi per cose accidentali". Sobre a concepção leopardiana da imaginação, ver a nota 64 do primeiro capítulo deste trabalho. 
mais forte, viva, vigorosa, ativa, fecunda e maior, tanto ainda é mais sombria, lúgubre, triste, melancólica, funesta e, pode-se dizer, feia. Como, abandonando as outras circunstâncias, ela é nutrida pela solidão, pelo silêncio, pela monotonia da vida; e a meridional pelas belezas e pela vitalidade e atividade da natureza; as obras daquela nascem entre as paredes de um quarto aquecido por estufas; as obras desta nascem, por assim dizer, sob o céu azul e dourado, em campos verdes e risonhos, em ares aquecidos e vivificados pelo sol $^{382}$.

Certamente Leopardi não descuida, nessas suas observações, de certa "inevitável"383 evolução histórica - relativa aqui a esse deslocamento meridional-setentrional; sul-norte, ou seja, da civilização -, mas identifica, nesse momento do Zibaldone di pensieri, a presença apenas de um "resíduo de imaginação" 384 nos novos protagonistas, ou seja, nos setentrionais. Tal "resíduo" se revela, pois, naquela "imaginação sóbria, abstrata, metafísica, e decorrente mais das verdades, da filosofia, da razão, que da natureza" ${ }^{385}$. Por conseguinte, é justamente a "falta das vivas e grandes ilusões extinguindo a imaginação alegre, brisa brilhante e, em suma, natural como a antiga, introduz a consideração do verdadeiro, o conhecimento da realidade das coisas, a meditação" 386 . Deriva dessa outra forma da "imaginação", exposta

${ }^{382}$ Cf. LEOPARDI, Giacomo. Zibaldone di pensieri, fragmento 3681-3682, 13.10.1823, in: Tutte le poesie, tutte le prose e lo Zibaldone, p. 2174: "Del resto l'immaginazione de' settentrionali rispetto alla meridionale quanto è, generalmente e tutta insieme, più forte, viva, vigorosa, attiva, feconda e maggiore, tanto ancora è più sombre, lúgubre, trista, malinconica, funesta e, si può dir, brutta. Perocché, lasciando l'altre circostanze, essa è nutrita dalla solitudine, dal silenzio, dalla monotonia della vita; e la meridionale dalle bellezze e dalla vitalità della natura; e le opere di quella nascono tra le pareti di una camera scaldata da stufe; le opere di questa nascono, per cosi dire, sotto un cielo azzurro e dorato, in campagne Verdi e ridenti, in un"ária riscaldata e vivificata dal sole".

${ }^{383}$ Ver aqui as observações de Lucio Felice. Meridionali, meridionalità, meridio. In: Lo Zibaldone cento anni dopo. Composizione,edizioni, temi. Atti del X Convegno Internazionale di studi leopardiani. Vol II. Set/1998, Recanati-Italia, Centro Nazioanle di Studi Leopardiani (CNSL), Firenze: OLSCHKI Editore, 2001, p. P.681

${ }^{384}$ Cf. Lucio Felice. Meridionali, meridionalità, meridio. In: Lo Zibaldone cento anni dopo. Composizione, edizioni, temi, p. 691.

${ }^{385}$ LEOPARDI, Giacomo. Zibaldone di pensieri, fragmento 275, 14.10.1820, in: Tutte le poesie, tutte le prose e lo Zibaldone, p. 1550: "immaginazione tetra astratta metafísica, e derivante più dalle verità, dalla filosofia, dalla ragione, che dalla natura".

${ }^{386}$ Ibidem: "la mancanza delle vive e grande illusioni spegnendo l'immaginazione lieta aerea brillante e insomma naturale come l'antica, introduce la considerazione del vero, la cognizione della realtà delle cose, la meditazione". 
anteriormente, como "abstrata" e "metafísica" em que se inscreve a "verdade", a "filosofia", a "razão", pois se distanciam, quer da "natureza" [natura], das "vagas ideias" [vaghe idee] correspondentes, portanto, à "imaginação primitiva" [immaginazione primitiva $]^{387}$.

Trata-se aqui da "imaginação" dos meridionais, conforme escreve Leopardi, aquela forma como se apresenta na Modernidade, ou, segundo Leopardi, sobretudo oggidí, pois

fundamentada no pensamento, [...] na metafísica, nas abstrações, na Filosofia, nas ciências, no conhecimento das coisas, nos dados exatos etc. Imaginativa que tem mais que tratar com a matemática sublime que com a poesia $^{388}$.

Aqui não se pode deixar de considerar, em particular nas observações leopardianas sobre os setentrionais, a problemática da Filosofia ${ }^{389}$. Daí se pressupor, antes de qualquer coisa, que na sua distinção - estabelecida com base, quer na influência do clima e na situação geográfica quer na distinção entre a mente e as tendências -, Leopardi compreende entre os meridionais, os greco-romanos, italianos, espanhóis e, em parte, os franceses, ou seja, intermediários entre sul e norte, e entre os setentrionais, alemães e ingleses ${ }^{390}$, algo importante também para a sua abordagem da filosofia moderna e, igualmente, para a sua postura ante as tendências metafísicas e abstratas modernas.

Certamente Leopardi se expressa como antimetafísico ${ }^{391}$, ou seja, refuta os filósofos metafísicos e abstratos, em particular, aqueles setentrionais alemães. Ele reconhece, no Discorso de 1824, que

387 Cf. LEOPARDI, Giacomo. Zibaldone di pensieri, fragmento 275, 14.10.1820, in: Tutte le poesie, tutte le prose e lo Zibaldone, p. 1550.

${ }^{388}$ LEOPARDI, Giacomo. Zibaldone di pensieri, fragmento 275, 14.10.1820, in: Tutte le poesie, tutte le prose e lo Zibaldone, p. 1550: "fondata sul pensiero, [...] sulla metafisica, sulle astrazioni, sulla filosofia, sulle scienze, sulla cognizione delle cose, sui dati esatti ec. Immaginativa che ha piuttosto che fare colla matematica sublime che colla poesia". 2001, p.75.

${ }^{389}$ Ver aqui POLIZZI, Gaspare (org.). Leopardi e la Filosofia. Firenze: Polistampa,

390 Cf. SANSONE, Mario. Storicità e letteratura da Machiavelli a Leopardi, Napoli: Edizioni Scientifiche Italiane, 1997, p. 215.

391 Cf. SANSONE, Mario. Storicità e letteratura da Machiavelli a Leopardi, p. 215. É importante destacar aqui a exposição realizada por Sansone acerca das fontes filosóficas de Leopardi, situadas em particular na filosofia do século XVIII. Nesse sentido tal crítico destaca 
a Itália, no que concerne à ciência filosófica e o conhecimento maduro e profundo do homem e do mundo, é incomparavelmente inferior à França, à Inglaterra, à Alemanha, considerando essas e aquela em geral $^{392}$.

Ademais, ainda no Discorso, Leopardi diz que os alemães, não obstante a "inclinação presente do espírito humano à pura observação e à experiência" [inclinazione presente dello spirito umano alla pura osservazione $e$ all'esperienza] ${ }^{393}$, "são ainda na literatura, [...] na Filosofia e nas ciências aquilo que eram os antigos precisamente" ${ }^{394}$. Em verdade, a avaliação leopardiana da nova cultura e filosofia alemã

estava vinculada às suas teorias geográficas e do clima setecentescas, e é ora afetuosa ora irônica, admirativa sempre, com uma veia sutil de superioridade e de desprezo [...]. Na sua mente permanece que os povos meridionais são (ou têm sido) os mais vivos e vitais, mais imaginosos e poéticos, mais geniais de uma genialidade integral, poemática e filosófica juntas ${ }^{395}$.

Aqui se revela, portanto, uma nova diferença em relação à orientação do Discorso no que concerne à problemática filosófica meridional, com base no Zibaldone di pensieri.

na sua exposição as formulações antimetafísicas leopardianas e o repúdio de Leopardi aos filósofos metafísicos e abstratos. Para Sansone quando Leopardi fala de "sua" metafísica não significa apreender princípios para além da experiência, mas aquelas formulações gerais que valem para fundamentar e justificar a construção empirista. Ele reconhece ainda que Leopardi fala não raramente de metafísica, mesmo quando aborda a problemática do seu sistema: embora não se trate de identificar o procedimento leopardiano com uma orientação abstrata e especulativa.

${ }^{392}$ Cf. LEOPARDI, Giacomo. Discorso sopra lo stato presente dei costumi degl'italiani, p. 57: "'Italia in fatto di scienza filosófica e di cognizione matura e profonda dell'uomo e del mondo è incomparabilmente inferiore alla Francia, all'Inghilterra, alla Germania, considerando queste e quella generalmente".

p. 82.

${ }^{393}$ Cf. LEOPARDI, Giacomo. Discorso sopra lo stato presente dei costumi degl'italiani,

${ }^{394}$ Cf. LEOPARDI, Giacomo. Discorso sopra lo stato presente dei costumi deglitaliani, p. 82: "sono ancora in letteratura e in filosofia ed in iscienze quel che erano gli antichi appunto".

395 Cf. SANSONE, Mario. Storicità e letteratura da Machiavelli a Leopardi, Napoli: Edizioni Scientifiche Italiane, 1997, p. 250: "è legata in Leopardi alle sue settecentesche teorie geografiche e del clima, ed è ora affettuosa ora irônica, ammirativa sempre con una sottile vena di superiorità e di dispregio [...] Nella sua mente sta che i popoli meridionali sono (o sono stati) $i$ piu vivi e vitali, più immaginosi e poetici, più geniali di una genialità integrale, poematica e filosófica insieme". 
Ao estabelecer um paralelo entre os italianos e os setentrionais no Zibaldone, Leopardi sustenta que os italianos, em virtude do entusiasmo deles, de um tempo, ser filho de

uma imaginação viva e mais rica que profunda, eram muito ativos, desse modo, agora, uma das razões pela qual não se apercebem ou ao menos se desesperam totalmente de uma vida sempre uniforme, e de uma inação perfeita, é a mesma imaginação igualmente rica e vária, e superabundância das sensações que deriva dela, a qual thes mergulha sem que disso percebam em uma espécie de rêve, como as crianças quando estão a sós ${ }^{396}$.

Tais observações preparam, com efeito, as considerações leopardianas sobre os setentrionais e, sobretudo, aquelas relativas às faculdades e modo de ser desses povos.

Leopardi dá continuidade às suas análises, argumentando sobre a "profundidade da mente" [profundità della mente]. Nesse sentido, ele se reporta à "faculdade de penetrar nos mais íntimos recantos do verdadeiro e do abstrato" ${ }^{397}$. Trata-se agora da disposição dos setentrionais na qual Leopardi reconhece como algo não desconhecido por eles, em particular, por aqueles que são "cultos" [cultt], pois a "sutileza, presteza e acuidade", ou seja, o "concebimento e a descoberta do verdadeiro, lá onde para os outros é preciso esforço, e por isso erram com frequência com toda a profundidade" ${ }^{\text {"398. }}$. Apesar disso, Leopardi observa não ser o "forte" deles, pois constitui, ao contrário, "a ocupação e, portanto, a infelicidade dos setentrionais cultos (observai com frequência os suicídios na Inglaterra), os quais não têm algo que os distraia da

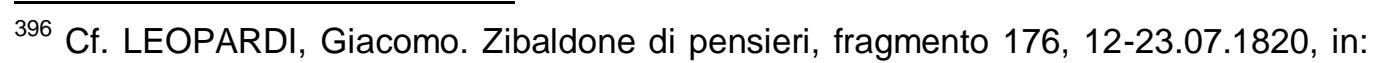
Tutte le poesie, tutte le prose e lo Zibaldone, p. 1527: "un'immaginazione viva e più ricca che profonda, erano attivissimi, così ora una delle cagioni per cui non si accorgono o almeno non si disperanno affatto di una vita sempre uniforme, e di una perfetta inazione, è la stessa immaginazione ugualmente ricca e varia, e la soprabbondanza delle sensazioni che ne deriva, la qualle gl'immerge senza che se n'avvedano in una specie di rêve, come i fanciulli quando son soli".

${ }^{397}$ Cf. LEOPARDI, Giacomo. Zibaldone di pensieri, fragmento 177, 12-23.07.1820, in: Tutte le poesie, tutte le prose e lo Zibaldone, p. 1527: "facoltà di penetrare nei più intimi recessi del vero dell'astratto".

${ }^{398}$ Cf. LEOPARDI, Giacomo. Zibaldone di pensieri, fragmento 177, 12-23.07.1820, in: Tutte le poesie, tutte le prose e lo Zibaldone, p. 1527: "il concepimento e la scoperta del vero, laddove agli altri bisogna più fatica, e perciò spesso sbagliano con tutta la profondità". 
consideração do verdadeiro" ${ }^{399}$. Ademais, embora pareça que a imaginação fosse neles algo muito caloroso e original, Leopardi diz: "Todavia [...] é antes filosofia e profundidade, que imaginação, e a poesia deles antes metafísica que poesia, vindo mais do pensamento que das ilusões" ${ }^{400}$.

Conforme o Zibaldone di pensieri, certos estados de ânimo possibilitam a "reflexão" [riflessione], a "profundidade do pensar" [profondità del pensare], ou seja, o peso da infelicidade, da monotonia, da sombra da tirania, do escrever melancólico, da "eloquência não mais viva e enérgica, mas lúgubre, profunda, filosófica" ${ }^{401}$. Por conseguinte, segue Leopardi,

a falta das vivas e grandes ilusões apagando a imaginação alegre, aérea, brilhante e, em suma, natural como a antiga, introduz a consideração do verdadeiro, o conhecimento da realidade das coisas, a meditação etc. da realidade das coisas, a meditação etc. e dá também lugar à imaginação sombria, abstrata, metafísica e decorrente mais das verdades, da Filosofia, da razão que da natureza, e das vagas ideias próprias naturalmente da imaginação primitiva ${ }^{402}$.

Trata-se aqui da "imaginação" como se apresenta nos setentrionais, pois possibilita, por causa da pouca vida da natureza, uma "imaginação fundada no pensamento" [immaginazione fondada sul pensiero] ${ }^{403}$. Daí também outras atividades que se desenvolvem em virtude da ausência de certa imaginação,

${ }^{399}$ LEOPARDI, Giacomo. Zibaldone di pensieri, fragmento 177, 12-23.07.1820, in: Tutte le poesie, tutte le prose e lo Zibaldone, p. 1527: "l'occupazione e quindi l'infelicità dei settentrionali colti (osservate perciò la requenza de' suicidi in Inghilterra), i quali non hanno cosa che li distragga dalla considerazione del vero".

400 Ibidem: "tuttavia [...] è piuttosto filosofia e profondità, che immaginazione, e la loro poesia piuttosto metafisica che poesia, venendo più dal pensiero che dalle illusioni".

${ }^{401}$ LEOPARDI, Giacomo. Zibaldone di pensieri, fragmento 275, 14.10.1820, in: Tutte le poesie, tutte le prose e lo Zibaldone, p. 1550: "eloquenza non più viva ed energica, mas lugubre, profonda, filosófica".

402 LEOPARDI, Giacomo. Zibaldone di pensieri, fragmento 275, 14.10.1820, in: Tutte le poesie, tutte le prose e lo Zibaldone, p. 1550: "la mancanza delle vive e grandi illusioni spegnendo l'immaginazione lieta aerea brillante e insomma naturale com l'antica, introduce la considerazione del vero, la cognizione della realtà delle cose, la meditazione ec. e dà anche luogo all'immaginazione tetra astratta metafisica, e derivante più dalle verità, dalla filosofia, dalla ragione, che dalla natura, e dalle vaghe idee proprie naturalmente della immaginazione primitiva".

${ }^{403}$ Cf. LEOPARDI, Giacomo. Zibaldone di pensieri, fragmento 275, 14.10.1820, in: Tutte le poesie, tutte le prose e lo Zibaldone, p. 1550. 
ou seja, primitiva ${ }^{404}$, uma vez que a dos setentrionais se fundamenta ainda "no pensamento, na metafísica, nas abstrações, na Filosofia, nas ciências, no conhecimento das coisas, nos dados exatos" ${ }^{405}$. Se a Grécia e a Itália - como na Antiguidade o tempo do belo ${ }^{406}$ e da "imaginação" - correspondem ainda à pátria e ao lugar, a inclinação natural dos setentrionais é, em verdade, no entender de Leopardi, a profundidade do entendimento, do verdadeiro, do melancólico.

Por isso, a "idade moderna" [età moderna] é "o tempo do pensamento, contudo, o setentrião é a pátria dele, e a Itália conserva, todavia, alguma coisa da sua natural imaginação, do seu belo, da sua natural disposição à alegria e à felicidade" ${ }^{407}$. Tais observações justificam certamente a interpretação leopardiana da relação entre tempos modernos e antigos, mas também entre meridionais e setentrionais, sobretudo, com respeito à imaginação e à Filosofia. Isso explica, igualmente, entre os setentrionais, o exemplo da Inglaterra: "tão cheia de Filosofia e de conhecimentos do homem" ${ }^{408}$, ou seja, de análise sobre

$\overline{404}$ Ao considerar a faculdade da imaginação em Leopardi, valendo-se da relação entre meridionais e setentrionais, Cassano fala da superioridade da imaginação meridional, dado que nasce da circunstância de ela se encontrar em harmonia com a natureza, ao passo que aquela setentrional é menos fácil, menos frívola e menos emotiva. Na continuidade de sua exposição, Cassano diz haver em toda qualidade o seu oposto, assim a imaginação meridional prejudica "a atividade externa" e por uma superabundância de vida interior "torna o Mezzogiorno rêveur, indolente e insouciant". Nesse sentido a ambivalência vale também para o tipo de imaginação prevalente nos países do Norte. Rápido, porém, Leopardi abandonará, segundo Cassano, essa tese para desenvolver aquela, muito mais interessante, da diversidade da imaginação setentrional, reconhecendo de haver dado vida, na idade moderna, a resultados superiores, na Filosofia e na Poesia, ou seja, naqueles produtos da imaginação meridional agora decaída (Cf.CASSANO, Franco. Oltre il nulla. Studio su Giacomo Leopardi, pp. 6-7).

${ }^{405}$ LEOPARDI, Giacomo. Zibaldone di pensieri, fragmento 275, 14.10.1820, in: Tutte le poesie, tutte le prose e lo Zibaldone, p. 1550: "sul pensiero,[...] sulla metafisica, sulle astrazioni, sulla filosofia, sulle scienze, sulla cognizione delle cose, sui dati esatti".

${ }^{406}$ Cf. LEOPARDI, Giacomo. Zibaldone di pensieri, fragmento 932, 12.04.1821, in: Tutte le poesie, tutte le prose e lo Zibaldone, p. 1671.

${ }^{407}$ LEOPARDI, Giacomo. Zibaldone di pensieri, fragmento 932, 12.04.1821, in: Tutte le poesie, tutte le prose e lo Zibaldone, p. 1671: "l'età moderna è il tempo del pensiero, nondimeno il settentrine ne à la patria, e l'Italia conserva tuttavia qualche poco della sua naturale immaginazione, del suo bello, della sua naturale disposizione alla letizia ed alla felicita".

408 LEOPARDI, Giacomo. Zibaldone di pensieri, fragmento 987, 25.04.1821, in: Tutte le poesie, tutte le prose e lo Zibaldone, p. 1684: "così pieno di filosofia, e cognizioni dell'uomo". 
o homem e sua natureza, como criatura da natureza, sem descuidar aqui das questões relativas aos governos ${ }^{409}$.

Aqui se apresenta um argumento decisivo, no que concerne à relação entre setentrionais e Filosofia na Idade moderna. Em tal argumento, Leopardi se reporta aos alemães, a certa orientação de pensamento e predomínio de disposições, de serem contrárias ao seu "sistema". Nesse sentido, ele defende:

Entre modernos, os alemães, certamente muito habilidosos nas matérias abstratas, parecem ser exceção para o meu sistema, e são totalmente o fundamento do sistema contrário [...] esses alemães nos quais a imaginação e o sentimento (falando em geral) são tão mais falsos, quer forçados, quer não naturais, quer frágeis em si mesmos, quanto aparecem mais vivos e extremos ${ }^{410}$.

Essas observações leopardianas prosseguem na crítica aos alemães, seja na sua forma de se conduzir na vida, seja na sua atividade de pensamento: predomínio de faculdades intelectivas e distantes da natureza. Para Leopardi, "a teoria deles, os sistemas deles, as filosofias deles, são na maior parte (a qualquer gênero pertençam: político, literário, metafísico, moral, etc. e também físico) poemas da razão"411. Por conseguinte, tudo isso pertence

409 Destacando ainda as considerações leopardianas sobre os ingleses e o conhecimento do homem, ver LEOPARDI, Giacomo. Zibaldone di pensieri, fragmento 3237 (22.08.1823), p. 2090: "Chiunque esamina la natura delle cose colla pura ragione, senz'aiutarsi dell'immaginazione nè del sentimento, nè dar loro alcun luogo, ch'è il procedere di molti tedeschi nella filosofia, come dire nella metafisica e nella politica, potrà ben quello che suona il vocabolo analizzare" [Quem quer que examine a natureza das coisas com a pura razão, sem se servir da imaginação nem do sentimento, nem lhes dar qualquer lugar, o qual é o proceder de muitos alemães na filosofia, por assim dizer, na metafísica e na política, será bem capaz daquilo que exprime o vocábulo analisar]. A nota relativa a esse fragmento acrescenta ainda: "Così anche parecchi inglesi, e generalmente tutti coloro che non sono assuefatti e non conoscono altro che studi e cose esatte. Ma certo è che di tali filosofi, metafisici, politicimatematici, ed aridi, ve n'ha più copia fra' ted[eschi] e dipoi fra' gl'ingl[esi] che altrove, come in Francia o in Italia" [Assim também muitos ingleses, e, em geral, todos aqueles que não estão habituados e não conhecem outra coisa senão estudos e coisas exatas. Mas é certo que de tais filósofos, metafísicos, político-matemáticos e áridos, existem mais cópias deles entre os alemães e, em seguida, entre os ingleses do que em qualquer outro lugar, como na França ou na Itália].

${ }^{410}$ LEOPARDI, Giacomo. Zibaldone di pensieri, fragmento 1850, 5-6.10.1821, in: Tutte le poesie, tutte le prose e lo Zibaldone, p. 1855: "Fra' moderni, i tedeschi, certo abilissimi nelle materie astratte, sembrano fare eccezione al mio sistema, e son tutto il fondamento cotrario [...] questi tedeschi ne' quali l'immaginazione e il sentimento (parlando in genere) è tanto più falso, e forzato, e innaturale e debole per se stesso, quanto apparisce più vivo ed estremo".

411 LEOPARDI, Giacomo. Zibaldone di pensieri, fragmento 2616, 29.08.1822, in: Tutte le poesie, tutte le prose e lo Zibaldone, p. 1979: "le loro teorie, i loro sistemi, le loro filosofie, 
a uma sociedade de literatos que levam uma "vida recolhida e incansavelmente estudiosa e de gabinete" ${ }^{412}$. Contudo, tal vida não torna a opinião e o pensamento deles independentes dos homens, ou mesmo da opinião dos outros mas, igualmente, das coisas ${ }^{413}$.

Em oposição à orientação filosófica e intelectual alemãs, Leopardi diz preferir os ingleses, pois

Grandes, [...] verdadeiras, consistentes descobertas sobre a natureza e a teoria do homem, dos governos etc. a física geral etc. disso fizeram os ingleses (como Bacon, Newton, Locke), os franceses (como Rousseau, Cabanis) e também algum italiano (como Galileu, Filangieri etc.), mas os alemães nenhuma, apesar de tudo aquilo que os filósofos deles escrevem seja, em certa razão, novo, e apesar dos alemães excederem em originalidade em todo gênero sobre qualquer outra nação literata (mas não sabem ser originais senão sonhando); e apesar da nação alemã ter tantos metafísicos, considerando também apenas os modernos, o quanto não têm deles as outras nações todas juntas, considerando os modernos e os antigos: e embora ela seja muito profunda de intelecto por natureza, e por uso ${ }^{414}$.

Leopardi prossegue nesse confronto com os setentrionais, com a sua crítica ao modo intelectual alemão, ou seja, à forma abstrata dos estudos desse povo. Daí os seus argumentos nos quais ele sustenta:

os literatos alemães têm precisamente em sumo grau aquilo que se exige do filósofo para não ser sonhador, e para não se distanciar do verdadeiro, indo na busca dele: o que os filósofos das outras nações não costumam ter. Vale dizer que os alemães têm um saber

sono per la più parte (a qualunque genere spettino: politico, letterario, metafísico, morale, ec. ed anche físico) poemi della ragione".

${ }^{412}$ Ibidem: "vita ritirata e indefessamente studiosa e di gabinetto".

${ }^{413}$ Cf. LEOPARDI, Giacomo. Zibaldone di pensieri, fragmento 2616, 29.08.1822, in: Tutte le poesie, tutte le prose e lo Zibaldone, p. 1979.

${ }^{414}$ LEOPARDI, Giacomo. Zibaldone di pensieri, fragmento 2616-2617, 29.08.1822, in: Tutte le poesie, tutte le prose e lo Zibaldone, p. 1979: "grandi e vere e sode scoperte sulla natura e la teoria dell'uomo, de governi ec. ec. la física generale ec. n'han fatto gl'inglesi (come Bacone, Newton, Locke), i francesi (come Rousseau, Cabanis) e anche qualche italiano (come Galilei, Filangieri ec.), ma i tedeschi nessuna, benchè tutto quello che i loro [...] filosofi scrivono, sia, per qualche conto, nuovo, e benchè i tedeschi abbondino d'originalità in ogni genere sopra ogni altra nazion letterata (ma non sanno essere originali se non sognando): e benchè la nazion tedesca abbia tanti metafisici, computando anche i soli moderni, quanti non ne hanno le altre nazioni tutte insieme, computando i moderni e gli antichi: e bench'ella Isa profondissima d'intelletto per natura, e per abito". 
imenso, um conhecimento quase (se é possível) inteiro e perfeito de todas as coisas que são e que foram. E assim sendo eles sujeitos da realidade em virtude do estudo deles, e os outros literatos sendo assim pouco senhores dos fatos, é realmente maravilhoso, como muito certo, que lá onde os outras nações já todas filosofando também poetando, os alemães poetando filosofando ${ }^{415}$.

Comparando as disposições dos alemães com a dos franceses, Leopardi conclui:

o mínimo e mais superficial dos filósofos franceses (tão leves e volages por natureza e por hábito) conhece melhor o homem efetivo e a realidade das coisas, daquilo que faça a maior e o mais profundo dos filósofos alemães (nação tão reflexiva) ${ }^{416}$.

Para Leopardi, o procedimento dos filósofos alemães, oposto àquele dos ingleses e franceses, termina em uma "profundidade [profondità] prejudicial a eles. Daí com esse procedimento, "o filósofo alemão tanto mais se distancia do verdadeiro, quanto mais se aprofunda ou se eleva; em oposição do que acontece a todos os outros" ${ }^{\prime 417}$. Leopardi reconhece que os alemães se encontram muito mais no "verdadeiro" [vero] quando eles "brincam" [scherzano] ou quando falam com certa "leveza" [leggerezza], ou ainda quando eles olham as coisas superficialmente do que quando pensam ${ }^{418}$. Disso resulta igualmente a sua crítica à filosofia criticista:

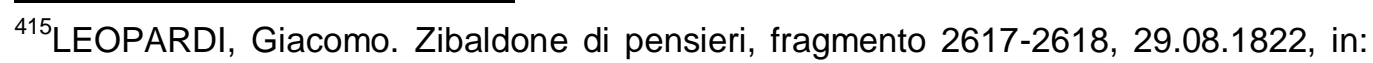
Tutte le poesie, tutte le prose e lo Zibaldone, p. 1979: "i letterati tedeschi hanno appunto in sommo grado quello che si richiedi al filosofo per non esser sognatore, e per non discostarsi dal vero andandone in cerca: il che i filosofi delle altre nazioni non sogliono avere. Vale a dir che i tedeschi hanno un sapere immenso, una cognizione quase (s'egli è possibile) intera e perfetta di tutte le cose che sono e che furono. Ed essendo essi cosi padroni della realtà per forza del Ioro Studio, e gli altri letterati essendo cosi poco padroni de' fatti, è veramente maraviglioso, como certissimo, che [...] laddove l'altre nazioni oramai tutte filosofano anche poetando, i tedeschi poetano filosofando".

${ }^{416}$ LEOPARDI, Giacomo. Zibaldone di pensieri, fragmento 2618, 29.08.1822, in: Tutte le poesie, tutte le prose e lo Zibaldone, p. 1979: 'i menomo e il più superficiale de' filosofi francesi (cosi leggieri e volages per natura e per abito) conosce meglio l'uomo effettivo e la realtà delle cose, di quel che faccia il maggiore e il più profondo de' filosofi tedeschi (nazione sì riflessiva)".

417 Ibidem: "il folosofo tedesco tanto più s'allontana dal vero, quanto più si profonda o s'inalza; all'opposto di cio che interviene a tutti gli altri".

418 Cf. LEOPARDI, Giacomo. Zibaldone di pensieri, fragmento 2617-2618, 2930.08.1822, in: Tutte le poesie, tutte le prose e lo Zibaldone, p. 1979. 
aquele romance de Wieland contém um maior número de verdades sólidas, ou novas, ou novamente deduzidas, ou novamente consideradas, desenvolvidas e expressas, também de gênero abstrato, que não contém a Crítica da razão de $\mathrm{Kant}^{419}$.

Contudo, ele conclui, tendo como questão a metafísica, "desculpar quem na metafísica amasse mais pensar que ler; que pretendesse ser metafísico sem haver lido ou compreendido Kant" ${ }^{\text {"20. }}$.

É certo que as formulações de Leopardi acerca dos filósofos alemães, franceses e ingleses pressupõe as suas reflexões sobre o que ele compreende por "um verdadeiro e perfeito filósofo" [un vero e perfetto filosofo]. Reportandose aqui ainda ao Zibaldone di pensieri, pode-se indicar um trecho no qual ele resume a natureza desse filósofo no seu proceder:

Afirmei em outro lugar que não se conhece perfeitamente uma verdade se não se conhecem perfeitamente todas as suas relações com todas as outras verdades, e com todo o sistema das coisas. Quais verdades conhecerão bem [...] aqueles filósofos que abstraem absolutamente e perpetuamente de uma parte essencialíssima da natureza?

A razão e o homem não aprendem senão por experiência. Se a razão quer pensar e operar por si mesma, e, em seguida, descobrir e fazer progressos Ihe convém conhecer por sua própria experiência; de outro modo a experiência dos outros, nas partes essenciais da natureza, não poderá lhe servir senão para repetir as operações feitas por outros.

Portanto, veja-se o quanto seja difícil encontrar um verdadeiro e perfeito filósofo. [...] (Aqui refleti [vós] o quanto o sistema das coisas favoreça o pretenso aperfeiçoamento do homem mediante a perfeição da razão e da filosofia). É inteiramente indispensável que tal homem seja sumo e perfeito poeta; mas não já para pensar como poeta; ao contrário, para examinar como pensador bastante frio e calculista aquilo que apenas 0 fervorosíssimo poeta pode conhecer. O filósofo não é

${ }^{419}$ LEOPARDI, Giacomo. Zibaldone di pensieri, fragmento 2618, 30.08.1822, in: Tutte le poesie, tutte le prose e lo Zibaldone, p. 1979: "quel romanzo di Wieland contiene un maggior numero di verità solide, o nuove, o nuovamente dedotte, o nuovamente considerate, sviluppate ed espresse, anche di genere astratto, che non ne contiene la Critica della ragione di Kant".

${ }^{420}$ Cf. LEOPARDI, Giacomo. Zibaldone di pensieri, fragmento 4304, 17.04.1828, in: Tutte le poesie, tutte le prose e lo Zibaldone, p. 2352: "scusare chi in metafisica amasse più di pensare che di leggere; chi pretendesse di essere metafísico senz'aver letto o inteso Kant". Ver ainda os comentários de PLACANICA, Augusto. Leopardi, o della modernità. In: LEOPARDI, Giacomo. Dei costumi degl'italiani, p. 104. 
perfeito, se ele não é senão filósofo, e se emprega a sua vida e a si mesmo apenas ao aperfeiçoamento da sua filosofia, da sua razão, ao puro encontro do verdadeiro, que é também a única e pura finalidade do perfeito filósofo. A razão precisa da imaginação e das ilusões que ela destrói; o verdadeiro do falso; o substancial do aparente; a insensibilidade mais perfeita da sensibilidade mais viva [...].

Tudo isso confirma aquilo que em outro momento eu disse da necessidade da imaginação para 0 grande filósofo ${ }^{421}$.

Essas observações de Leopardi integram disposições e faculdades humanas necessárias, no seu entender, ao procedimento do filósofo capaz de apreender e unir na sua investigação os elementos que constituem as coisas na sua integralidade, exigindo do pensador uma disposição capaz de reconhecê-la e considerá-la no pensamento.

\subsection{A Itália e as outras nações civis europeias: barbárie e civilização}

As considerações sobre a relação entre meridional e setentrional no Zibaldone di pensieri e sobre certos aspectos relativos ao processo de civilização e os novos tempos, conduzem à exposição para um paralelo entre a Itália e as outras nações europeias. No Discosso de 1824, Leopardi diz que "os italianos possuem antes usos e hábitos que costumes" [gl'Italiani hanno

421 Ver LEOPARDI, Giacomo. Zibaldone di pensieri, fragmentos 1838-1839 (04.10.1821), pp. 1852-1853: "Ho detto altrove che non si conosce perfettamente una verità se non si conoscono perfettamente tutti i suoi rapporti con tutte le altre verità, e con tutto il sistema delle cose. Qual verità conosceranno dunque bene quei filosofi che astraggono assolutamente e perpetuamente da una parte essenzialissima della natura? La ragione e l'uomo non impara se non per l'esperienza. Se la ragione vuol pensare e operare da se, e quindi scoprire, e far progressi, le conviene conoscere per sua propria esperienza; altrimenti l'esperienza altrui nelle parti essenziali della natura, non potrà servirle che a ripetere le operazioni fatte da altri. Quindi si veda quanto sia difficile a trovare un vero e perfetto filosofo [...] (Qui riflettete quanto il sistema delle cose favorisca il preteso perfezionamento dell'uomo mediante la perfezione della ragione e della filosofia.) È del tutto indispensabile che un tal uomo sia sommo e perfetto poeta; ma non già per ragionar da poeta; anzi per esaminare da freddissimo ragionatore e calcolatore ciò che il solo ardentissimo poeta può conoscere. II filosofo non è perfetto, s'egli non è che filosofo, e se impiega la sua vita e se stesso al solo perfezionamento della sua filosofia, della sua ragione, al puro ritrovamento del vero, che è pur l'unico e puro fine del perfetto filosofo. La ragione ha bisogno dell'immaginazione e delle illusioni ch'ella distrugge; il vero del falso; il sostanziale dell'apparente; l'insensibilità la più perfetta della sensibilità la più viva; [...] Tutto ciò conferma quello che altrove ho detto della necessità dell'immaginazione al gran filosofo". 
piuttosto usanze e abitudini che costumi ${ }^{422}$ e no fragmento 2923 do Zibaldone di pensieri, ele retoma a ideia, acrescentando ainda algo: "Os italianos não têm costumes: eles têm usos. Assim todos os povos civis que não são nações" ${ }^{\text {"23 }}$. Também no seu Epistolario, Leopardi, em uma carta enviada ao irmão Carlo Leopardi, escreve: "os romanos, e talvez nem também os italianos, não têm costumes" [i Romani, e forse né anche gl'Italiani, non hanno costumi] ${ }^{424}$.

Tais argumentos se articulam, não obstante as fontes aqui indicadas, revelando um diagnóstico da situação italiana e das outras nações civis europeias. Por conseguinte, a Itália não teria conseguido

entrar na Modernidade, e ao mesmo tempo, não tem mais em si nenhum perfume do bom tempo antigo. É, portanto, condenada à infelicidade pelo seu viver civil mesquinho que, não podendo ser perenemente neutro, se acomoda no pior. Responsabilidade da história? Responsabilidade da Igreja? Leopardi invoca sim a história do mundo moderno, mas sem aprofundar os elementos constitutivos: não é o seu ofício. Da Igreja não fala, mas em algum lugar [...] a vê estática e alienada pela Modernidade, e, todavia, condenada ao crepúsculo imposto pela progressiva incredulidade; e talvez aquele seu Renascimento, amado como início da novidade, e odiado como pai da insinceridade mesquinha, nos faz ir outra vez às polêmicas de Maquiavel e de Guicciardini acerca da maldade da côrte de Roma, e às bem mais modernas recriminações em direção a uma Itália desprovida de Reforma, mas abundante de Contrareforma e de seus estilos, morais e culturais ${ }^{425}$. p. 75 .

${ }^{422}$ Cf. LEOPARDI, Giacomo. Discorso sopra lo stato presente dei costumi degl'italiani,

${ }^{423}$ Cf. LEOPARDI, Giacomo. Zibaldone di pensieri, fragmento 2923, 09.07.1823, in: Tutte le poesie, tutte le prose e lo Zibaldone, p. 2034: "Gl'italiani non hanno costumi: essi hanno delle usanze. Così tutti i popoli civili che non sono nazioni”.

${ }^{424}$ Ver carta de 18 de janeiro de 1823 em LEOPARDI, Giacomo. Epistolario, in: Tutte le poesie, tutte le prose e lo Zibaldone, p. 1233. Sobre a diferença entre costumes, usos e hábitos na reflexão leopardiana sobre o estado presente dos italianos, ver o comentário de Ezio Raimondi apresentado na nota 104 do primeiro capítulo deste trabalho.

${ }^{425}$ PLACANICA, Augusto. Leopardi e il mezzogiorno del mondo, p. 153: "entrare nella modernità, e al contempo, non ha più in sè alcun profumo del buon tempo antico. È dunque condannata all'infelicità del suo meschino vivere civile, che, non potendo essere perennemente neutro, si adágia nel peggio. Responsabilità della storia? Responsabilità della Chiesa? Leopardi invoca sì la storia del mondo moderno, ma senza approfondirne gli elementi costitutivi: non è il suo mestiere. Della Chiesa non parla, ma altrove [...] la vede statica e aliena dalla modernità, e tuttavia condannata al crepuscolo imposto dalla progrediente incredulità; e forse quel suo Rinascimento, amato come inizio della novità, e odiato come padre dell'insincerità trista, ci fa riandare alle polemiche di Machiavelli e di Guicciardini circa la scelleratezza della corte di 
Contudo, além desse diagnóstico apresentado por Leopardi e comentado pelos estudiosos ${ }^{426}$ do Discorso de 1824, deve-se também considerar, valendo-se do Zibaldone di pensieri outra reflexão sobre a Itália e as outras nações civis em um contexto mais amplo da civilização. Nesse sentido, Leopardi escreve no Zibaldone di pensieri que:

É muito notável na consideração comparativa das antigas e das modernas nações civis, que aquelas foram totalmente de situação meridional. Da Itália não era bem civil que a parte meridional. Do resto da Europa, a Grécia apenas. Da Ásia, apenas o mezzodì, quer aquele civilizado dos gregos, e quer a Índia, a Pérsia etc. Da África não falo, a qual é toda meridional $^{427}$.

Para Leopardi, isso produz e produziu, por sua vez, diferenças consideráveis, nos costumes, nos modos de vida, nos exercícios, nas instituições públicas e privadas, nas características dos povos civis e da civilização antiga, dos costumes, dos caracteres, da civilização moderna ${ }^{428}$.

Comparando certos comportamentos de povos e o "sentimento de nação" [sentimento di nazione], Leopardi diz que o "mais humano, bem educado e sem preconceitos, francês ou inglês, encontrando-se com forasteiros, acredita sempre cordialmente e sinceramente se encontrar com um inferior a si”429. Tal sentido de superioridade é uma mola, uma fonte de orgulho

Roma, e alle assai più moderne recriminazioni verso un'Italia priva di Riforma ma abbondante di Controriforma e di suoi stili, morali e culturali". Para uma compreensão da reflexão sobre a Igreja e a religião em Maquiavel e Guicciardini, ver aqui MACHIAVELLI, Niccolò. Discorsi sopra la prima Deca di Tito Livio [1531], in: Tutte le opere storiche, politiche e letterarie. 1998, pp. 8085; GUICCIARDINI, Francesco. Ricordi. Milano: Ugo Mursia, 1994, pp. 66, 80, 115, 120, 121 122.

${ }^{426}$ Destaca-se aqui, em particular, as observações de Augusto Placanica, Lucio Felici, Mario Sansone, Bruno Biral, Luigi Russo e Mario Andrea Rigoni, no que concerne às questões do diagnóstico da Itália apresentado por Leopardi em seu Discorso de 1824.

${ }^{427}$ LEOPARDI, Giacomo. Zibaldone di pensieri, fragmento 4256, 14.03.1827, in: Tutte le poesie, tutte le prose e lo Zibaldone, p. 2335: "Ë molto notabile nella considerazione comparativa delle antiche e delle moderne nazioni civili, che quelle furono tutte quante di situazione meridionali. Dell'Italia non era ben civilie che la parte meridionale. Del resto dell'Europa, la Grecia sola. Dell'Asia, solo il mezzodì, sì quello civilizzato daí greci, e si l'India, la Persia ec. Dell'Africa non parlo, la quale è meridionale tutta".

${ }^{428}$ Cf. LEOPARDI, Giacomo. Zibaldone di pensieri, fragmento 4256, 14.03.1827, in: Tutte le poesie, tutte le prose e lo Zibaldone, p. 2335.

429 LEOPARDI, Giacomo. Zibaldone di pensieri, fragmento 4261, 25.03.1827, in: Tutte le poesie, tutte le prose e lo Zibaldone, p. 2337: "più umano e ben educato e spregiudicato 
e de estima de si com preconceito ou diminuição dos outros ${ }^{430}$. Já os alemães poderiam, conforme Leopardi, apresentar o mesmo sentimento, "mas são impedidos disso pela divisão deles, pelo não existir nação alemã”431. Os russos, por sua vez, sentem-se "meio bárbaros" [mezzo barbari $]^{432}$, e os suecos, os dinamarqueses, os holandeses sentem ser "muito pequenos e de pouco poder" ${ }^{333}$. Os espanhóis, acrescenta Leopardi, quer da época de Carlos $\mathrm{V}$ quer de Felipe II, tiveram esse sentimento de superioridade, como confirmam as histórias, e o mesmo ocorreu com os franceses, ingleses da sua época, assim os portugueses ${ }^{434}$.

Para Leopardi é preciso, porém, uma indagação: "mas quem leva hoje em consideração os espanhóis e os portugueses, falando de povos civis?"435 Quanto aos italianos, o que Leopardi diz sobre o "sentimento de nação" [sentimento di nazione]?. Os italianos talvez tiveram tal sentimento de nação, e parece realmente que sim: a civilização deles era "superior àquela de todo o resto da Europa. Dos italianos de hoje não falo; não sei bem se haja"436. Contudo, essa "estima grande de si mesmo" [stima grande di se stesso] ${ }^{437}$ revela "o primeiro fundamento da moralidade e dos alvos e ações nobres e

francese o inglese, non può mai far che trovandosi con forestieri, non si creda cordialmente e sinceramente di trovarsi com un inferiore a se".

${ }^{430}$ Cf. LEOPARDI, Giacomo. Zibaldone di pensieri, fragmento 4261, 25.03.1827, in: Tutte le poesie, tutte le prose e lo Zibaldone, p. 2337.

${ }^{431}$ Cf. LEOPARDI, Giacomo. Zibaldone di pensieri, fragmento 4261, 25.03.1827, in: Tutte le poesie, tutte le prose e lo Zibaldone, p. 2337: "ne sono impediti dalla lor divisione, dal non esserci nazion tedesca".

432 Cf. LEOPARDI, Giacomo. Zibaldone di pensieri, fragmento 4261, 25.03.1827, in: Tutte le poesie, tutte le prose e lo Zibaldone, p. 2337.

${ }^{433}$ Cf. LEOPARDI, Giacomo. Zibaldone di pensieri, fragmento 4261, 25.03.1827, in: Tutte le poesie, tutte le prose e lo Zibaldone, p. 2337: "troppo piccoli, e di poter poco".

${ }^{434}$ Cf. LEOPARDI, Giacomo. Zibaldone di pensieri, fragmento 4261, 25.03.1827, in: Tutte le poesie, tutte le prose e lo Zibaldone, p. 2337.

435 Cf. LEOPARDI, Giacomo. Zibaldone di pensieri, fragmento 4261, 25.03.1827, in: Tutte le poesie, tutte le prose e lo Zibaldone, p. 2337: "ma chi pone oggi in conto gli Spagnuoli e i Portoghesi, parlando di popoli civili?".

${ }^{436}$ Cf. LEOPARDI, Giacomo. Zibaldone di pensieri, fragmento 4261, 25.03.1827, in: Tutte le poesie, tutte le prose e lo Zibaldone, p. 2337: "superiore a quella di tutto il resto d'Europa. Degl'italiani d'oggi non parlo; non so ben se ve n'abbia".

${ }^{437}$ Cf. LEOPARDI, Giacomo. Zibaldone di pensieri, fragmento 4262, 25.03.1827, in: Tutte le poesie, tutte le prose e lo Zibaldone, p. 2338. 
honradas" ${ }^{38}$. Esse "orgulho nacional" [orgoglio nazionale] se torna, por sua vez, nos franceses e ingleses, "bastante desagradável e odioso para os forasteiros" ${ }^{439}$.

Ainda analisando o modo civil dos povos europeus, Leopardi se reporta aos ingleses e diz que eles "não se batem por boa educação" [non si piccano di buona creanza $]^{440}$, mas os franceses, ao contrário,

por isso não apenas se batem, mas querem ser, acreditam ser, e certamente são a gente melhor educada do mundo. Aliás, nisso fundam em grande parte aquela opinião de superioridade deles. [...] Eles viajam entre nós triunfalmente, demonstrando-nos o desprezo deles, pondo-nos em ridículo na nossa própria face e falando para nós [...], e de nós eles não recebem o mínimo golpe, [...] nem nas cartas nem na imprensa. De que provém isto? da bondade dos italianos, ou da ingenuidade, ou do medo, ou de que outra coisa?" ${ }^{441}$.

Certamente, as observações e análises leopardianas dos povos e o seu interesse em relação às expressões deles, não seguem uma orientação sistemática ou mesmo orgânica ${ }^{442}$. Nesse quadro apresentado por Leopardi das nações e povos - aquele do gênero humano nas suas longas vicissitudes ${ }^{443}$ - em que povos e nações não são olhados "com curiosidade, em um modo ocasional, espalhado, mas são analisados intensamente na natureza

438 LEOPARDI, Giacomo. Zibaldone di pensieri, fragmento 4262, 25.03.1827, in: Tutte le poesie, tutte le prose e lo Zibaldone, p. 2338: "il primo fondamento sì della moralità, sì delle mire ed azioni nobili e onorate".

439 LEOPARDI, Giacomo. Zibaldone di pensieri, fragmento 4262, 25.03.1827, in: Tutte le poesie, tutte le prose e lo Zibaldone, p. 2338: "assai dispiacevole e odioso ai forestieri".

${ }^{440}$ Cf. LEOPARDI, Giacomo. Zibaldone di pensieri, fragmento 4262, 25.03.1827, in: Tutte le poesie, tutte le prose e lo Zibaldone, p. 2338.

${ }^{441}$ Cf. LEOPARDI, Giacomo. Zibaldone di pensieri, fragmento 4262, 25.03.1827, in: Tutte le poesie, tutte le prose e lo Zibaldone, p. 2338: "non solo se ne piccano, ma vogliono essere, credono essere, e certo sono, la meglio educata gente del mondo. Anzi in questo fondano per gran parte quella loro opinione di superiorità". [...] essi viaggiano tra noi trionfalmente, dimostrandoci il lor disprezzo, mettendoci in ridicolo in faccia nostra própria e parlando a noi [..] e [...]da noi non ricevono il menomo colpo, [...] nè in lettere, nè in istampa. Da che vien questo? da bontà degl'italiani, o da dabbenaggine, o da paura, o da che altro?". 1999, p. 257.

442 Cf. RUSSO, Fabio. Leopardi politico o della felicità impossibile. Roma: Bulzoni,

${ }^{443}$ Cf. RUSSO, Fabio. Leopardi politico o della felicità impossibile. Roma: Bulzoni, 1999, p. 257. 
íntima deles, segundo uma componente ética, política, existencial ou um determinado tom de cultura e tipo de costume" ${ }^{444}$.

O Zibaldone di pensieri esboça também um quadro histórico da Antiguidade e do processo civilizatório. Nesse quadro, a Antiguidade se desloca gradualmente, ou seja, do Oriente ao Ocidente ${ }^{445}$. Nesse processo, Leopardi indica como momento culminante - aquele de extrema harmonia entre homem e natureza - a civilização grega e romana. Se os orientais são assim considerados por Leopardi como pertencentes à antiga meridionalidade, algo se apresenta também em sua análise desses povos, a saber, a questão dos "grandes erros contrários à natureza [grandi errori contrari alla natura] ${ }^{446}$.

Aqui Leopardi introduz, seja uma historicização da antiguidade seja a ideia de "erro" [errore] contrário à natureza: algo que contribui também para se compreender a relação entre barbárie e civilização na sua reflexão sobre os antigos e modernos. No Zibaldone, ele escreve:

Em qualquer nação ou antiga ou moderna se encontram grandes erros contrários à natureza, como qualquer grande conhecimento contrário à natureza; naquele lugar não se encontra nada ou bem pouco de grande, de belo, de bom. $E$ isso é um dos principais motivos pelos quais as nações orientais ainda que grandes, ainda que a história delas remonte a tempos muito antigos, tempos habitualmente companheiros do grande e do belo; ainda que muito ignorantes em última análise, e, portanto, desprovidas dos grandes obstáculos da razão e do verdadeiro, e isto também hoje em dia; todavia não ofereçam quase nada de grande verdadeiro nem de belo verdadeiro, e isso tanto com respeito às ações, aos costumes, ao entusiasmo e virtude da vida, quanto às produções do engenho e da imaginação ${ }^{447}$.

${ }^{444}$ RUSSO, Fabio. Leopardi politico o della felicità impossibile, p. 257: "con curiosità, in un modo occasionale, sparpagliato, ma sono intensamente analizzati nella loro intima natura, secondo una componente etica, politica, esistenziale o un determinato tono di cultura e tipo di costume".

${ }^{445}$ FELICI, Lucio. Meridionali, meridionalità, meriggio in: Lo Zibaldone cento anni dopo. Composizione,edizioni, temi. Atti del X Convegno Internazionale di studi leopardiani. Vol II, p. 688.

${ }^{446}$ Cf. FELICI, Lucio. Meridionali, meridionalità, meriggio in: Lo Zibaldone cento anni dopo. Composizione, edizioni, temi, p. 688.

${ }^{447}$ Cf. LEOPARDI, Giacomo. Zibaldone di pensieri, fragmento 926-927, 10.04.1821, in: Tutte le poesie, tutte le prose e lo Zibaldone, p. 1669-1670: "In qualunque nazione o antica o moderna s'incontrano grandi errori contrari alla natura, come dovunque grandi cognizioni 
Ao prosseguir na sua exposição, Leopardi justifica porque os gregos e os romanos ultrapassam todos os povos antigos. Em grande parte, ele sustenta

os erros e ilusões deles foram na máxima parte muito semelhante à natureza, de maneira que se encontram igualmente distantes da corrupção da ignorância, e do defeito dessa. Ao contrário povos orientais cuja superstição e erros [...] foram e são em grande parte contrários à natureza, e portanto com verdade podem se chamar bárbaro. E pode-se dizer que nenhum povo antigo, na ordem do grande e do belo, pode ser comparado aos gregos e romanos ${ }^{448}$.

Para Leopardi, disso pode decorrer ainda algo: que talvez os "séculos de ouro" [secoli d'oro] de outros povos, a saber, o dos egípcios, chineses e persas, tendo vindo muito antes, uma vez que são povos muito antigos, pode ocorrer que

a memória deles não tenha chegado até nós, mas permanecido no escuro da antiguidade, com o qual vem coincidir a época dos ditos séculos; e ao contrário nos tem chegado a memória apenas da corrupção e barbárie deles, ocorrida naturalmente à civilização e que se abateu ao ser contemporânea da grandeza e da flor dos povos gregos e romanos, cuja grandeza ocupa e domina efetivamente em tempos mais próximos de nós. Aliás se pode dizer que o quanto aqui há de grande e de belo com respeito à antiguidade nas histórias, e em geral, em qualquer memória nossa, tudo pertence á última época da antiguidade, da qual os gregos e os romanos foram efetivamente os últimos povos $^{449}$.

contrari alla natura; quivi non s'incontra niente o ben poco di grande di bello di buono. E questo è l'uno de' principali motivi per cui le nazioni orientali, ancorchè la loro storia rimonti a tempi antichissimi, tempi ordinariamente compagni del grande e de bello; ancorchè ignorantissime in ultima analisi, e quindi prive dei grandi ostacoli della ragione e del vero, e questo anche oggidì; tuttavia non offrano quase niente di vero grande nè di vero bello, e cio tanto [...] riguardo alle azioni, ai costumi, all'estusiasmo e virtù della vita, quanto alle produzioni dell'ingegno e della immaginazione".

${ }^{448}$ Cf. LEOPARDI, Giacomo. Zibaldone di pensieri, fragmento 927, 10.04.1821, in: Tutte le poesie, tutte le prose e lo Zibaldone, p.1670: "i loro errori e illusioni furono nella massima parte conformissime alla naturam sicchè si trovarono egualmente lontani dalla corruzione dell'ignoranza, e dal difetto di questa. Al contrario de' popoli orientali le cui superstizioni ed errori [...] furono e sono in gran parte contrarie alla natura, e quindi con verità si possono chiamar barbare. E si pùo dire che nessun popolo ântico, nell'ordine del grande e del bello, pùo venire in paragone de' greci e de' Romani".

${ }^{449}$ Cf. LEOPARDI, Giacomo. Zibaldone di pensieri, fragmento 927, 10.04.1821, in: Tutte le poesie, tutte le prose e lo Zibaldone, p. 1670: "la memoria loro non è passata fino a noi, ma rimasta nel buio dell'antichità, col quale viene a coincidere la época dei detti secoli; e per lo 
Por conseguinte, Leopardi sustenta que o "erro contrário à natureza" [errore contrario alla natura] ${ }^{450}$ é aquele que, na verdade, caracteriza a verdadeira barbárie, pois ocorre nas sociedades em decadência em que as características originais se corromperam em virtude do predomínio da razão e de falsos princípios de civilização ${ }^{451}$. Leopardi ainda esboça no Zibaldone di pensieri outro quadro com mais detalhes sobre a passagem da civilização antiga, do Oriente ao Ocidente. Nesse quadro, como indicam os fragmentos 2332-2333 do Zibaldone di pensieri, ele apresenta outro conceito, o de "civilização mediana" [civiltà mezzana]. Essa "civilização mediana" é, portanto, "mais próxima ao excesso da barbárie, que ao excesso da civilização" ${ }^{452}$. Daí Leopardi escrever:

a natureza já fugida também da Grécia, permanecia nesse fundo da Europa: aí surgia a medíocre civilização (mais próxima ao excesso da barbárie, que ao excesso de civilização a qual após os assírios, os egípcios, os persas, tinham chegado também os gregos); e esta os fêz sujeitos do mundo: e sempre que a meia civilização encontrar-se em meio a povos não tocados completamente pela civilização, ou a povos [...] plenamente civilizados [...]; sempre que uma nação, uma pátria existir em meio a povos que jamais tenham tido, ou pela extrema civilização tenham perdido a nação e a pátria; a civilização mediana triunfará sobre todo o mundo, e aquela nação que resta, ou que nasce, por pequena que seja, tornar-se-á conquistadora, e assinará o seu nome no catálogo das nações que têm dominado universalmente; até que esse mesmo domínio não a reduzirá ao estado das potências vencidas por ela, e destruirá o seu poder. O que hoje,

contrario ci è pervenuta la memória sola della loro corruzione e barbarie, succeduta naturalmente alla civiltà, e abbattutasi ad esser contemporânea della grandezza e del fiore dei popoli greco e Romano, la qual grandezza occupa [...] e signoreggia le storie nostre, alle quali per la maggior vicinanza de' tempi ha potuto pervenire, e perch'ella signoreggiò effettivamente in tempi più vicini a noi. Anzi si può dire che quanto ci ha di grande e di bello rispetto all'antichità, della quale i greci e i Romani furono effettivamente gli ultimi popoli".

${ }^{450}$ Cf. Felici, Lucio. Meridionali, meridionalità, meriggio in: Lo Zibaldone cento anni dopo. Composizione,edizioni, temi. Atti del X Convegno Internazionale di studi leopardiani. Vol II, p. 689.

${ }^{451}$ Cf. Felici, Lucio. Meridionali, meridionalità, meriggio in: Lo Zibaldone cento anni dopo. Composizione,edizioni, temi. Atti del X Convegno Internazionale di studi leopardiani. Vol II, p. 689.

${ }^{452}$ Cf. LEOPARDI, Giacomo. Zibaldone di pensieri, fragmento 2332, 06.01.1822, in: Tutte le poesie, tutte le prose e lo Zibaldone, p. 1670: "più vicina all'eccesso della barbarie, che all'eccesso della civilizazione". 
por causa da marcha acelerada das coisas humanas, ocorrerá mais rápido que ocorria antigamente ${ }^{453}$.

Aqui se conclui um argumento relevante na reflexão desenvolvida no Zibaldone di pensieri, ou seja, o de meridione e civilização meridional. Para Leopardi, a civilização meridional, em seus aspectos positivos, segue, portanto, o suceder da "civilização mediana" [civiltà mezzana], ou seja, como convivência equilibrada com a natureza. Tal "civilização" conserva da barbárie aquilo que não se apresenta como naturalidade corrompida. Todavia, se a civilização, como interpreta Leopardi, vai do Sul ao Norte, por sua vez "pátria do pensamento" [patria del pensiero], logo a meridionalidade - atividade vital em que se expressa a imaginação natural e o belo - vai se esgotando em virtude crescente da razão. Nesse sentido Leopardi conclui que a civilização antiga foi uma civilização meridional e a nossa uma civilização setentrional ${ }^{454}$.

${ }^{453}$ Cf. LEOPARDI, Giacomo. Zibaldone di pensieri, fragmento 2332-2333, 06.01.1822, in: Tutte le poesie, tutte le prose e lo Zibaldone, p. 1670: "la natura già fuggita anche dalla Grecia, restava in questo fondo d'Europa: vi sorgeva la medíocre civiltà (più vicina all'eccesso della barbarie, che all'eccesso della civilizazione a cui dopo gli Assiri, gli Egizi, i Persiani, erano arrivati anche i greci); e questa li fece padroni del mondo: e sempre che la mezzana civiltà troverassi in mezzo o a popoli non tocchi affatto da incivilimento, o a popoli [...] pienamente inciviliti [...], sempre che una nazione una pátria esistera in mezzo a popoli che non abbiano mai avuta, o per l'estremo incivilimento abbiano perduta la nazione e la pátria; la mezzana civiltà trionferà di tutto il mondo, e quella nazione che resta, o che nasce, per piccola che sia, diverrà conquistatrice, e segnerà il suo nome nel catalogo delle nazione che hanno dominato universalmente; fiche qusto medesimo domínio non la ridurrà allo stato delle potenze da lei vinte, e distruggerà il suo potere. II che oggi, stante la Márcia accelerata delle cose umane, avverrá più presto che non soleva anticamente".

${ }^{454}$ Cf. Felici, Lucio. Meridionali, meridionalità, meriggio in: Lo Zibaldone cento anni dopo. Composizione,edizioni, temi. Atti del X Convegno Internazionale di studi leopardiani. Vol II, p. 690. 


\section{PARTE II}

MODERNIDADE E CRÍTICA LEOPARDIANA À NOVA BARBÁRIE: NEGATIVIDADE DOS TEMPOS MODERNOS 
E veramente l'uomo e le nazioni sono capaci, come di stato selvaggio, di barbarie, di civiltà, tutti stati ben distinti tra loro per genere, cosi di diverse specie di civiltà, distinte non solo per semplici nuances, come quelle che distinguono era la civiltà presso le diverse nazioni colte, ma per caratteri speciali, essenziali, determinati dalle circostanze, e spesso e in gran parte dal caso ${ }^{455}$.

Giacomo Leopardi. Zibaldone di pensieri

In somma la civiltà moderna ci há portati al lato opposto dell'antica, e non si può comprendere come due cose opposte debbano esser tutt'uno, vale a dire civiltà tutt'e due. Non si trati di piccole differenze, si tratta di contrarietà sostanziali: o gli antichi non erano civili, o noi non lo siamo ${ }^{456}$.

Giacomo Leopardi. Zibaldone di pensieri

Vários fragmentos do Zibaldone di pensieri leopardiano defendem que tudo aquilo que há de "grande" e de "belo" pertence a última época da Antiguidade, a saber, aos gregos e romanos, efetivamente os últimos povos. Leopardi defende que no processo de civilização revela-se também certo paradoxo, ou seja, de que o desenvolvimento da consciência, do saber, da razão provocou nesse processo a dissipação das ilusões, ou seja, de bem, justiça, amor, glória, pátria, as quais davam sentido ao viver de indivíduos, sociedades e povos.

${ }^{455}$ Cf. LEOPARDI, Giacomo. Zibaldone di pensieri, fragmento 4171, 21.03.1826, in: Tutte le poesie, tutte le prose e lo Zibaldone, p. 2307.

${ }^{456}$ Cf. LEOPARDI, Giacomo. Zibaldone di pensieri, fragmento 163, 10.07.1820, in: Tutte le poesie, tutte le prose e lo Zibaldone, p. 1523. 
O "estado presente do mundo" [stato presente del mondo] é, para Leopardi, bárbaro, pois no presente ocorre a dissolução dos vínculos sociais, na medida em que desapareceram as antigas ilusões, produzidas por uma "imaginação" não contrária à natureza, e possibilitadora de uma vida vigorosa. Predomina, porém, no estado presente, um "amor próprio mal dirigido" [un amor proprio mal diretto] e mal empregado, pois orientado para as vantagens reais próprias, não aquelas que se originam do "heroísmo", dos "sacrifícios", das "virtudes", da "honra", da "amizade", todos voltados para si ${ }^{457}$.

Nesse estado presente, ou "sociedade", como Leopardi ironiza, todos estão em guerra contra todos e retornam no mundo "costumes selvagens, e daquela primeira idade" [costumi selvaggi, e di quella prima età] ${ }^{458}$. Têm-se, com efeito, costumes que "no estado de sociedade são bárbaros, porque destrutivos da sociedade, e contrários diretamente à sua essência, razão, e finalidade" ${ }^{\text {"59 }}$. Leopardi reconhece então que toda sociedade dominada pelo "egoísmo individual" [egoismo individuale] é bárbara, e bárbara da maior barbárie ${ }^{460}$.

457 Cf. LEOPARDI, Giacomo. Zibaldone di pensieri, fragmento 671, 17.02.1821, in: Tutte le poesie, tutte le prose e lo Zibaldone, p. 1625.

458 Cf. LEOPARDI, Giacomo. Zibaldone di pensieri, fragmento 674, 17.02.1821, in: Tutte le poesie, tutte le prose e lo Zibaldone, p. 1625.

459 Cf. LEOPARDI, Giacomo. Zibaldone di pensieri, fragmento 674, 17.02.1821, in: Tutte le poesie, tutte le prose e lo Zibaldone, p. 1625: "nello stato di società son barbari, perchè distruttivi della società, e contrari direttamente all'essenza ragione, e scopo suo".

460 Deve-se aqui recordar a conclusão da Scienza nuova de 1744 e, sobretudo, o parágrafo 1106 em que Vico comenta sobre o último mal estar civil e destaca igualmente os danos causados por vários séculos de barbárie decorrente das sutilezas de engenhos maliciosos com a "barbárie da reflexão" [barbarie della riflessione] (Cf. VICO, Giambattista. Princìpi di scienza nuova d'intorno alla comune natura delle nazione [1744], in: Opere, Tomo I, Milano: Armando Mondadori, 2001, pp. 967-968). 


\section{CAPITULO III}

Fim do antigo ethos e Modernidade: a reflexão leopardiana

A reflexão de Leopardi sobre o deslocamento da civilização meridional, aquela que caracterizava o mundo antigo nas suas expressões culturais e nos seus costumes mantidos pelas ilusões, apresenta-se como parâmetro ético e político no seu confronto com a Modernidade e na sua diagnose em relação ao processo civilizatório moderno. O Discorso de 1824, e alguns fragmentos do Zibaldone, apresentaram, de forma concreta, os elementos dessa diagnose, destacando alguns pressupostos para a compreensão do mundo moderno e de sua especificidade como nova época, após a strage delle illusioni, mais a presença de certo substituto e compensação em algumas nações com os novos princípios orientadores da ação nas società strette. Daí ser preciso aqui um aprofundamento da relação entre illusione e strage delle illusioni, a fim de uma reflexão sobre o advento da Modernidade e o fim do antigo ethos.

\subsection{O Renascer da civilização na Europa do século XV}

Ainda no Discorso de 1824, Leopardi combateu a falsa ideia de se considerar comumente a "civilização moderna" [civiltà moderna] como libertadora da Europa em relação ao estado antigo, por se tratar de um "falso conceito" [falso concetto], que deformaria, em geral, a apreciação, o pensamento e o verdadeiro modo de se pensar a história, as vicissitudes do gênero humano e as nações. Esse erro, como "engano" [svista] substancial, perturbaria e falsificaria, no seu entender, a ideia do que "um filósofo pode conceber de grande sobre dita história e sobre os seus progressos ou desenvolvimentos do espírito humano" ${ }^{\prime 41}$.

Para enfrentar esse equívoco, Leopardi se reporta, de modo especial, ao que ele denomina de "ressurgimento" [risorgimento], ou seja, o Renascimento, defendendo que a civilização, ao contrário das concepções comuns, ressurge da "barbárie dos baixos tempos, não do estado antigo" [dalla barbarie de' bassi tempi non dallo antico ${ }^{462}$. Conforme os argumentos do Discorso de 1824, o

${ }_{461}$ LEOPARDI, Giacomo. Discorso sopra lo stato presente dei costumi degl'italiani, pp. 72-73: "un filosofo può concepire in grande sulla detta storia e sui progressi o andamenti dello spirito umano".

p. 73.

${ }^{462}$ Cf. LEOPARDI, Giacomo. Discorso sopra lo stato presente dei costumi degl'italiani, 
renascimento da civilização, das artes e da inteligência, ao avançar e se difundir, "não nos libertou do antigo, mas, ao contrário, da total e horrível corrupção do antigo. Em suma, a civilização não nasceu no século XV na Europa, mas renasceu" ${ }^{\prime 463}$

Entretanto, esse renascer da antiga civilização não representa, para Leopardi, uma civilização totalmente conforme à primeira, ou seja, aquela antiga, pois, de acordo com a seguinte expressão leopardiana, beaucoup s'en faut, porque as circunstâncias de então não o permitiram e, talvez, tenham até distanciado a antiga civilização, mais do que nunca, por causa do progresso. Tal distanciamento não se limita, na diagnose de Leopardi, a uma análise apenas do universo das criações culturais, mas revela, sobretudo, preocupações morais, éticas e políticas na forma da sociedade constituída e organizada politicamente, ou seja, como ethos. Segundo ele afirma:

mas enquanto ela [a nova civilização] nos torna diferentes dos antigos, pode-se talvez duvidar muito se ela traga um benefício para os indivíduos e para as nações e se favoreça à felicidade, virtude e grandeza tanto de uns, considerados separadamente, quanto das outras [nações], consideradas cada uma no seu corpo, e todas juntas ${ }^{464}$.

Na sua reflexão sobre o Renascimento é preciso destacar, de um lado, o reconhecimento das conquistas realizadas nesse período no domínio das Letras e da cultura e, de outro, os problemas no âmbito da sociedade e de sua organização, isto é, no universo no qual se apresentam questões como a liberdade e a possibilidade de criação. Leopardi reconhece outra grande causa responsável, no universo dos estudos, da língua, da poesia, "do extinguir-se que causou a originalidade verdadeira e a faculdade criativa na literatura italiana, originalidade consumada com Dante e Petrarca, isto é, logo após o

${ }^{463}$ LEOPARDI, Giacomo. Discorso sopra lo stato presente dei costumi degl'italiani, p. 73: "non ci hanno liberato dall'antico, ma anzi dalla totale e orribile corruzione dell'antico. In somma la civiltà non nacque nel quattrocento in Europa, ma rinacque".

${ }^{464}$ LEOPARDI, Giacomo. Discorso sopra lo stato presente dei costumi degl'italiani, p. 73: "ma in quanto ella ci rende diversi dagli antichi, si può forse molto dubitare se ella faccia un benefizio agl'individui e alle nazioni e se giovi alla felicità, virtù e grandeza sì degli uni separatamente considerati, e sì dell'altre considerate ciascuna in corpo, e tutte insieme". 
nascimento dessa literatura" ${ }^{465}$ Trata-se aqui da "extinção da liberdade, e a passagem da forma republicana à monarquia, a qual obrigou o espírito impedido e afugentado, ou limitado nas ideias e nas coisas, a se dirigir às palavras" ${ }^{466}$. Quando se reporta ao século XVI na Itália, e fora dela, ele afirma ter sido "totalmente monárquico [...], quanto ao governo" ${ }^{467}$. Logo em seguida, ele acrescenta que "as letras italianas renasceram do sono do século XV sob Cósimo e Lourenço dos Medici, fundadores da monarquia toscana e destruidores daquela república" ${ }^{468}$. Nesse renascimento, como depois com Leão $X$, "as letras tomaram uma forma regular, uma forma totalmente diferente daquela do século $X I V^{469}$, e mais, daquela que se costumava tomar no ressurgimento [...] ou nascer delas" ${ }^{470}$.

O Discorso destaca, na sua reflexão sobre as Letras, a ideia de uma "forma regular" na criação, propondo certa interpretação da relação entre antigos e modernos, e da situação dos séculos XIV, XV e XVI na configuração do poético. Leopardi se reporta, em seguida, às épocas, a fim de pensar a natureza do poético em conformidade com o desenvolvimento da civiltà. Por isso empreende uma análise confrontando as épocas com base na questão do poético. Ele escreve: "O século XV permaneceu por fazer, mas conservava a ideia do belo incorrupta; porém, embora não fizesse, considerava assim

465 LEOPARDI, Giacomo. Zibaldone di pensieri, fragmento 392, 08.12.1820, in: Tutte le poesie, tutte le prose e lo Zibaldone, p. 1574: "dell'estinguersi che fece subitamente l'originalità vera e la facoltà creatrice nella letteratura italiana, originalità finita con Dante e il Petrarca, cioè subito dopo la nascita di essa letteratura".

466 Ibidem: "l'estinzione della libertà, e il passaggio dalla forma republicana, alla monarchica, la quale costringe lo spirito impedito, e scacciato o limitato nelle idee e nelle cose, a rivolgersi alle parole".

${ }^{467}$ Ibidem: " tutto monarchico [...], quanto al governo".

${ }^{468}$ Ibidem, pp. 1574-1575: "le lettere italiane risorsero dal sonno del quatrocento, sotto Cosimo e Lorenzo de' Medici fondatori della monarchia toscana e distruttori di quella repubblia".

${ }^{469}$ Grifo nosso

470 Ibidem, p.1575: "le lettere presero una forma regolare, una forma tutta diversa da quella del trecento, e (quel che è più) da quella che sogliono sempre prendere nel loro risorgimento $[. .$.$] o nascere".$ 
mesmo o fato, ou melhor, o buscava: por isso o infinito estudo dos Clássicos e a erudição dominante no século" ${ }^{471}$.

É precisamente essa outra causa responsável pelo extinguir-se da originalidade em razão da extinção da liberdade um argumento relevante nessa diagnose leopardiana, identificada no regime monárquico. Ademais, nesse renascer as Letras assumem também uma "forma regular": algo diferente do século XIV. Por conseguinte, o século XVI parecia a Leopardi um século em que a prosa e a poesia se reduziram à arte, ou seja, são enfraquecidas pela teoria. Nessas suas formulações, ele segue uma disposição, quanto as épocas e as Letras, na qual o século XIV se apresenta como comunal e poético, o século XV impoético e erudito e o século XVI, monárquico e regular. Nesse sentido, o século XVI parece haver traído o século XIV, abandonando os ensinamentos dos primeiros pais, conduzindo assim a língua e as Letras italianas para uma orientação alheia.

Nas primeiras páginas do Zibaldone di pensieri, Angelo Poliziano e Pulci se destacavam como expressões singulares na miséria de um século sem infâmia e sem louvores, ou seja: "o século XV não foi corrupção nem refinamento do século XIV, mas um sono da literatura (que havia dado lugar à erudição), a qual permanecia ainda não corrompida e pecava ainda pouco"472. Leopardi retornará ainda no Zibaldone ao argumento do "sono" [sonno] literário do século XV, mais adiante, apresentando uma visão mais complexa sobre o desenvolvimento das Letras na Itália, com base em certo patrimônio ideal e a perda irremediável de uma virtude originária. Trata-se da extinção de certa originalidade verdadeira, ou seja, da faculdade criativa presente no nascimento da literatura ${ }^{473}$.

${ }^{471}$ Ibidem: "Il quattrocento restò dal fare, ma conservava l'idea del bello incorrotta; però benchè non facesse, purê apprezzava il fato anzi lo cercava: quindi l'infinito studio de' Classici e l'erudizione dominante nel secolo".

472 LEOPARDI, Giacomo. Zibaldone di pensieri, fragmentos 1-2, Luglio o Agosto, 1817, in: Tutte le poesie, tutte le prose e lo Zibaldone, p. 1465: "il quattrocento non fu corruzione né raffinamento del trecento, ma un sonno della letteratura (che avea dato luogo all'erudizione) la quale restava ancora incorrotta e peccava ancora più tosto di poco".

${ }^{473}$ Cf. TATEO, Francesco, Leopardi e il Quattrocento, in: Leopardi e la letteratura italiana dal duecento al seicento, Atti del IV Convegno Internazionale di studi leopardiani, Recanati-Italia, 13-16.09.1976, Centro Nazionale di Studi Leopardiani (CNSL),Firenze: Olschki editore, 1978, p. 154. 
Se no início de suas primeiras abordagens sobre Poliziano e Pulci, eram destacados como expressões opostas ao sono do século $\mathrm{XV}$, o ressurgimento do "sono" passa a ser identificados com os representantes da idade dos Medicis, ou seja, Cósimo e Lourenço. Na abordagem leopardiana ambos estão associados ao prolongamento daquela ausência de originalidade, a qual marcou o fim do século XIV. Esse prolongamento é justificado por Leopardi com base no momento político, ou seja, a queda da liberdade republicana e a instituição da monarquia. Por isso, essa forma de regime caracterizou, conforme a interpretação leopardiana do século XVI da literatura, a dita "forma regolare" ou a regularidade, pois se apresenta com forma diversa daquela do século XIV.

Tal designação leopardiana revela, portanto, a ausência de inventividade, ou seja, a crise da inventio no domínio literário que as Letras assumiram no momento de seu advento e ressurgimento. $O$ que é relevante destacar na sua abordagem desse momento do Renascimento, não é apenas o esforço de Leopardi em corresponder a abordagem da história literária a uma consideração de ordem política, mas também a sua orientação que "atribuía ao século XV o início de uma corrupção cujo século XVI pôs fim, mas sobre um plano imitativo e, portanto, "regular", por outra direção da avaliação positiva do renascimento mediceo, a qual era difícil renunciar, parece se entregar a um esquema historiográfico que atribui ao primeiro século $\mathrm{XV}$ a responsabilidade de haver interrompido o processo iniciado no século XIV, e a segunda parte do século o início de uma obra de reconstrução, embora condicionada no plano humano e político por um regresso a formas autoritárias e limitada ao plano literário do academicismo"474. Isso justificaria as considerações expressas no Zibaldone di pensieri de apresentar a experiência humanista dos Medici, e o próprio Lourenço de Medici, em uma via da "corrupção", em virtude da forma regolare de uma justificação com base no regime monárquico.

${ }^{474}$ Cf. TATEO, Francesco, Leopardi e il Quattrocento, in: Leopardi e la letteratura italiana dal duecento al seicento, Atti del IV Convegno Internazionale di studi leopardiani, p.155. 


\subsection{As Luzes e o renascer da civilização}

Se o Discorso tratou a civilização renascida, abordando a experiência do Renascimento, também a civilização moderna vem interpretada por Leopardi com base na experiência das Luzes. Para Leopardi, os grandes e incontestáveis feitos da civilização renascida decorrem também do fato de ela haver

nos libertado daquele estado igualmente distante da cultura e da natureza próprios dos baixos tempos, isto é, de tempos muito corrompidos; daquele estado que não era nem civil nem natural, ou seja, propriamente e simplesmente bárbaro, daquela ignorância muito pior e mais nociva do que a das crianças e dos homens primitivos, da superstição, da vileza e covardia cruel e sanguinária, da inércia e timidez ambiciosa, intrigante e opressora, da tirania à oriental, inquieta e mortífera, do abuso excessivo do duelo ${ }^{475}$

Contra o Medievo, Leopardi apresenta esse elenco de delitos dos "baixos tempos" [tempi bassi] e critica também a condição da nobreza, ou seja, a da feudalidade:

do Baronado e da vassalagem, do celibato voluntário ou forçado, eclesiástico ou secular, da falta de toda indústria e deterioração e fraqueza da natureza, do despovoamento, pobreza, fome, peste que seguiam a cada instante de tais razões, dos ódios hereditários das famílias, das guerras contínuas e mortais e devastações, incêndios de cidades e de campos entre Reis e Barões, Reis e súditos, Barões e Barões, Barões e vassalos, cidades e cidades, facções e facções, subdivisões de partidos, famílias e famílias, pelo espírito não de heroísmo, mas de cavalaria e de assassinato, pela ferocidade nunca usada para a pátria nem para nação, pela total falta de nome e de amor nacional pátrio, e de nações, pelas desordens horríveis no governo, aliás, por nenhum governo, nenhuma lei, nenhuma forma constante da república e administração, incerteza da justiça, dos direitos, das

475 LEOPARDI, Giacomo. Discorso sopra lo stato presenti dei costumi degl'italiani, p. 73; "averci liberato da quello stato egualmente lontano dalla coltura e dalla natura próprio de' tempi bassi, cioè di tempi corrottissimi; da quello stato che non era né civile né naturale, cioè propriamente e semplicimente bárbaro, da quella ignoranza molto peggiore e più danosa di quella de' fanciulli e degli uomini primitivi, dalla superstizione, dall viltà e codardia crudele e sanguinária, dall'inerzia e timidità ambizioza, intrigante e opressiva, dalla tirannide all'orientale, inquieta e micidiale, dall'abuso eccessivo del duelo". 
leis, dos institutos e regulamentos, tudo em poder, discrição e prazer da força, e essa geralmente possuída e usada sem coragem, e a coragem nunca para a pátria e os perigos nunca encontrados para ela, nem para a glória, mas por dinheiro, por vingança, por ódio, por baixas ambições e paixões, ou por superstição e preconceitos, os vícios não cobertos de alguma cor, as culpas não reparadas por nenhuma justificação, os costumes atrevidamente infames também nos maiores e naqueles também faziam profissão de vida e de caráter mais santo, guerras de religião, intolerância religiosa, inquisição, venenos, suplícios horrendos contra os reis verdadeiros ou supostos, ou os inimigos, nenhum direito das gentes, tortura, provas de fogo, e coisas semelhantes ${ }^{476}$.

Leopardi reconhece que a "civilização moderna" [civiltà moderna] libertou o gênero humano desse conjunto de atrocidades cometidas pela sociedade anterior, não obstante identificar ainda na Modernidade, a permanência de várias "relíquias" [reliquie], ou seja, resíduos da época anterior, mas que vão, aos poucos, se dissipando nos "progressos diários" [progressi giornalier]. Isso ocorreria por meio da liberação, inclusive das consequências e dos avanços e opiniões que pudessem ainda favorecer esses obstáculos:

busca e se esforça de [...] liberar a nova filosofia nascida, pode-se dizer, não ainda dois séculos completos, e tencionada a terminar justamente e aperfeiçoar o [...] ressurgimento, a partir dos abusos, preconceitos (bem piores que a ignorância), deprevação e barbárie dos baixos tempos; por isso digna apenas de elogios, gratidão, glória, favor, cultura

\footnotetext{
$\overline{476}$ LEOPARDI, Giacomo. Discorso sopra lo stato presenti dei costumi degl'italiani, pp. 73-74: "dal Baronaggio e dal vassallaggio, dal celibato volontario o forzoso, ecclesiastico o secolare, dalla mancanza d'ogn'industria e deperimento e languore dell'agricoltura, dalla spopolazione, porvertà, fame, peste che seguivano ad ogni tratto da tali cagioni, dagli odii ereditarii e di família, dalle guerre continue e mortali e devastazioni e incendi di Baroni, Baroni e vassali, città e città, fazioni e fazioni, e suddivisioni di partiti, famiglie e famiglie, dallo spirito non d'eroismo ma di cavalleria e d'assassineria, dalla ferocia non mai usata per la pátria né per la nazione, dalla total mancanza di nome e di amor nazionale e pátrio, e di nazioni, daí disordini orribili nel governo, anzi dal niun governo, niuna legge, niuna forma costante di repubblica e amministrazione, incertezza della giustizia, de' diritti, delle leggi, degl'instituti e regolamenti, tutto in potestà e a discrezione e piacere della forza, e questa per lo più posseduta e usata senza coraggio, e il coraggio non mai per la pátria e i pericoli non mai incontrati per lei, né per gloria, mas per danari, per vendeta, per odio, per basse ambizioni e passioni, o per superstizioni e pregiudizi, i vizi non coperti d'alcun colore, le colpe non curanti di giustificazione alcuna, i costumi sfacciatamente infami anche ne' più grandi e in quelli eziandio che facean professione di vita e carattere più santo, guerre di religione, intolleranza religiosa, inquisizione, veleni, supplizi orribili verso i rei veri o pretesi, o i nemici, niun diritto delle genti, tortura, prove del fuoco, e cose tali".
} 
e só por isso útil ou, pelo menos, por isso
principalmente ${ }^{477}$.

O Discorso leoapardiano alude ainda às reações daqueles que se opõem a novidade da época das Luzes ante o confronto do atraso do status cultural e político dos "baixos tempos". Falando das mudanças e do confronto em relação a certos resquícios, Leopardi escreve:

Esse estado e natureza das coisas, propriamente falando, ou as consequências e seus avanços, ou os usos, as opiniões e as formas pertencentes ou correspondentes a elas, amam, defendem, elogiam, buscam reter e salvar da destruição da moderna filosofia, aqueles que choram, condenam, reprovam, opõem, combatem a civilização moderna e as luzes do século e os seus progressos, e aqueles que fizeram o mesmo nos séculos passados, aqueles que apelam ou apelaram o antigo, e se chamam defensores dele e conservadores e o tomam como uniforme, e gritam, se indignam contra a novidade ${ }^{478}$.

Daí a ironia leopardiana contra esses reacionários ante o avanço das Luzes, de que eles esquecem que "o verdadeiro antigo é em grande parte aquilo, portanto, que eles combatem" ${ }^{479}$. Para Leopardi, não há coisa mais propriamente antiga "do que aquelas que eles chamam novidade e que impugnam como tais e se admiram com elas como coisas até então ignoradas pelo gênero humano, e contrárias à experiência e, porém, muito perniciosas" ${ }^{480}$.

477 LEOPARDI, Giacomo. Discorso sopra lo stato presenti dei costumi degl'italiani, p. 74; "procura e sforzasi di liberarci la nuova filosofia nata, si può dire, non ancor sono due secoli, e intenta propriamente a terminare e perfezionare il nostro risorgimento dagli abusi, pregiudizi (peggiori assai che l'ignoranza), depravazione e barbarie de' tempi bassi; degna perciò solo di lode e gratitudine e gloria e favore e coltura, e perciò solo utile o almeno perciò principalmente".

478 LEOPARDI, Giacomo. Discorso sopra lo stato presenti dei costumi degl'italiani, pp. 74-75: "Questo stato e natura di cose, propriamente parlando, o gli effetti ed avanzi suoi, o gli usi, le opinioni e le forme ad essa appartenenti o corrispondenti, amano, difendono, lodano, cercano di ritenere e salvare dalla distruzione a cui sono incamminate i nemici della moderna filosofia, quelli che piangono, condannano, biasimano, oppugnano, combattono la civiltà moderna e i lumi del secolo e i suoi progressi, e quelli che fecero il simile ne' passati secoli, quelli che richiamano o richiamano l'antico, e se ne chiamano difensori e conservatori e lo prendono per loro divisa, e gridano e s'indegnano contro la novità".

${ }^{479}$ LEOPARDI, Giacomo. Discorso sopra lo stato presenti dei costumi deglitaliani, p. 75; "il vero antigo è in gran parte quello appunto che essi combattono".

480 Ibidem: "di quelle che essi chiamano novità e che impugnano come tali e se ne maravigliano gravemente come cose finora ignote al genere umano, e contrarie all'esperienza, e però perniciosissime". 
Convém aqui destacar, o sentido amplo, assumido por Leopardi no Discorso de 1824, abordando a relação entre ethos antigo e o "espírito amplo do ressurgimento", quer no que diz respeito ao Renascimento italiano quer no que concerne as Luzes. Leopardi assegura que "nas artes e na literatura o espírito do ressurgimento não foi de nos distanciar do antigo, nem também de nos conduzir além do que atingiram os antigo (o que talvez [fosse] impossível, e talvez absolutamente mal e nocivo e corrupção em si mesmo)" ${ }^{\text {"81 }}$. Aquilo que pretendeu o Renascimento foi nos liberar do gótico, mas

nem as artes nem a literatura modernas apesar ainda do grandíssimo estudo que os cultores de uma e da outra fizeram [...] dos antigos exemplos, foram, porém, jamais conforme às antigas, nunca e menos diversas segundo a época, os gêneros, os escritores, os artesãos, apesar do antigo ser reconhecido como sumo mestre e muito especial em tais tarefas; assim deve-se discorrer quanto aos costumes e ao estado moderno das nações, embora esses e a moderna civilização não sejam nem jamais tenham sido conforme ao antigo ${ }^{482}$.

Quanto ao processo civilizatório moderno, Leopardi assegura, nos fragmentos indicados por ele no Zibaldone, que a meta dessa civilização devia ser a de reconduzir o gênero humano "quase à civilização antiga ofuscada e extinta pela barbárie dos tempos do meio" ${ }^{483}$. Não obstante esse intento da civilização moderna, ele reconhece certa especificidade da antiga civilização, quando comparada àquela moderna. A antiga civilização estava "quase no ponto justo" [quasi nel giusto punto], ou seja, "naquele meio entre dois

$\overline{481}$ LEOPARDI, Giacomo. Discorso sopra lo stato presenti dei costumi degl'italiani, p. 75: "Come nelle arti e nella letteratura lo spirito del risorgimento non è stato di allontanarci dall'antico, né anche di portarci più oltre che non giunsero gli antichi (il che forse è impossibile, e forse assolutamente male e danoso, e corruzione per se medesimo)". Essa passagem é indicada no Discorso numa nota de pé de página, a qual reenvia aos seus pensamentos contidos no Zibaldone, fragmentos 162-163, 10.07.1820.

482 LEOPARDI, Giacomo. Discorso sopra lo stato presenti dei costumi deglitaliani, p. 75: "né le arti né la letteratura moderna malgrado ancora il grandíssimo studio che i cultori dell'uma e dell'altre han fato e fanno continuamente degli antichi esempi, sono però né mai sono state conformi alle antiche, ma più e men diverse secondo l'epoche e i generi e gli scrittori e gli artefici, benché l'antico sia riconosciuto per maestro sommo e specialissimo in tali faccende; così dee discorrersi quanto ai costumi e allo stato moderno delle nazioni, bench'questi e la moderna civiltà non sai né mai sia stata conforme all'antico". Esse trecho se encontra na mesma nota de pé de página como indicado na nota anterior.

${ }^{483}$ LEOPARDI, Giacomo. Zibaldone di pensieri, fragmento 162, 10.07.1820, in: Tutte le poesie, tutte le prose e lo Zibaldone, p. 1523: "apresso a poco alla civiltà antica offuscata ed estinta dalla barbarie dei tempi di mezzo". 
excessos, só o qual podia obter para o homem na sociedade certa felicidade" ${ }^{484}$. Segundo Leopardi, a barbárie dos baixos tempos não tinha "uma rudeza primitiva, mas uma corrupção do bom, por isso muito nociva e muito funesta" ${ }^{485}$. A intenção do processo civilizatório devia ser o de eliminar "a ferrugem da espada já bela, ou lhe acrescentar somente um pouco de brilho" ${ }^{486}$.

Porém, algo ocorreu, a nova civilização foi além, querendo "refinar"[raffinare] e "afiar"[aguzzare] a espada a ponto de rompê-la ${ }^{487}$. Nessa imagem, Leopardi representa a sua ideia do processo civilizatório moderno, na medida em que concebe haver a Modernidade conservado, em grande parte, 0 "nocivo" [cattivo] dos baixos tempos. Sendo, portanto, mais moderno, a nova civilização eliminou tudo aquilo

que permanecia [...] neles de bom do antigo, pela maior proximidade (de cujo antigo em tudo e por tudo destruíram), como a existência e certo vigor do povo e do indivíduo, um espírito nacional, os exercícios do corpo, uma originalidade e variedade de costumes característicos e usos etc. ${ }^{488}$

Se o processo civilizatório moderno abrandou, de um lado, a tirania dos "baixos tempos", mas, de outro, a tornou eterna, lá onde não durava naquele tempo, seja por causa do excesso, seja pelos motivos acima expostos. Ao extinguir as "comoções" e "turbulências civis", como o fizeram os antigos, "não asseguraram o ordem, mas a perenidade, tranquilidade e imutabilidade da desordem e a nulidade da vida humana" ${ }^{489}$. Para Leopardi, a civilização

\footnotetext{
${ }^{484}$ Ibidem: "in quel mezzo tra i due eccessi, il quale solo poteva proccurare all'uomo in società una certa felicità".

485 Ibidem: "una rozzezza primitiva, ma una corruzione del buono, perciò dannosissima e funestissima".

${ }^{486}$ Ibidem: "la ruggine alla spada già bella, o accrescergli solamente un poco di lustro".

${ }^{487}$ Cf. LEOPARDI, Giacomo. Zibaldone di pensieri, fragmento 162, 10.07.1820, in: Tutte le poesie, tutte le prose e lo Zibaldone, p. 1523.

488 LEOPARDI, Giacomo. Zibaldone di pensieri, fragmentos 162-163, 10.07.1820, in: Tutte le poesie, tutte le prose e lo Zibaldone, p. 1523: "che restava [...] loro di buono dall'antico per la maggior vicinanza (del quale antico in tutto e per tutto abbiam fatto strage), come l'esistenza e un certo vigore del popolo, e dell'individuo, uno spirito nazionale, gli esercizi del corpo, un'originalità e varietà di caratteri costumi usanze ec.".

489 LEOPARDI, Giacomo. Zibaldone di pensieri, fragmento 163, 10.07.1820, in: Tutte le poesie, tutte le prose e lo Zibaldone, p. 1523: "non ha assicurato l'ordine ma la perpetuità tranquilità e immutabilità del disordine, e la nulità della vita umana".
} 
moderna conduziu os homens para o lado oposto daquela antiga, sendo impossível se compreender "como duas coisas opostas devam ser a mesma coisa" ${ }^{490}$. Não há aqui pequenas diferenças, como Leopardi adverte, mas se trata de uma contradição substancial. Daí sustentar: "ou os antigos não eram civilizados, ou nós não o somos"491.

\subsection{Permanência das ilusões nas antigas repúblicas e a $\pi \lambda \varepsilon o v \varepsilon \xi i ́ a$ na monarquia}

O interesse de Leopardi pela questão da liberdade e a sua relação com as formas de organização política se inscrevem no sistema da natureza e das ilusões que revela certa alusão ao ethos antigo, ou seja, a uma vida compreendida como totalidade. Justamente esse suporte das ilusões orienta Leopardi em seu percurso pelos diversos ordenamentos políticos, em especial antigos, como pressuposto de sua diagnose do mundo moderno. Nesse percurso se destaca a sua preocupação com a felicidade, uma vez já concebido no seu sistema o homem como livre em contato com a natureza: algo que serve de parâmetro desde a remota antiguidade até o seu presente.

Conforme Leopardi escreve em um fragmento de 1820 do Zibaldone di pensieri: "a proteção da liberdade das nações não é a Filosofia nem a razão, como agora se pretende que essas devam regenerar as coisas públicas, mas as virtudes, as ilusões, o entusiasmo, em suma, a natureza da qual estamos muito distantes" ${ }^{492}$. Daí Leopardi eleger, e acredita não exagerar, o "estado antigo e das antigas repúblicas" ${ }^{493}$. Ele reconhece, porém, que estavam igualmente sujeitas "a muitas calamidades, muitas dores, muitos males. Inconvenientes inevitáveis no próprio sistema magistral da natureza, quanto

\footnotetext{
490 Ibidem: "come due cose oposte debbano esser tutt'uno".

491 Ibidem: "o gli antichi non erano civili, o noi non lo siamo".
}

492 LEOPARDI, Giacomo. Zibaldone di pensieri, fragmento 115, 07.06.1820, in: Tutte le poesie, tutte le prose e lo Zibaldone, p. 1510: "la salvaguardia della libertà delle nazioni non è la filosofia nè la ragione, come ora si pretende che queste debbano rigenerare le cose pubbliche, ma le virtù, le illusioni, l'entusiasmo, in somma la natura, dalla quale siamo lontanissimi".

${ }^{493}$ LEOPARDI, Giacomo. Zibaldone di pensieri, fragmento 1096, 27.05.1821, in: Tutte le poesie, tutte le prose e lo Zibaldone, p. 1078: "stato antico, e delle antiche repubbliche". 
mais nas ordens que finalmente são, mais ou menos, obra humana!" ${ }^{494}$. O seu argumento consiste em estabelecer uma "proporção" [proporzione] e "comparação" [paragone] da felicidade ou infelicidade dos homens antigos com aquela dos modernos: "no balanço e na análise da massa dos bens e dos males junto a uns e junto a outros" 495 .

Nesse estado antigo, e das antigas repúblicas, permanecia ainda "tanta natureza, tanta força de crenças naturais ou ilusões, para poder manter o estado democrático, e conseguir nele certa felicidade e perfeição de governo"496. Tal estado é, conforme Leopardi escreve,

muito favorável às ilusões, ao entusiasmo [...] um estado que exige grande ação e movimento, um estado onde cada ação pública dos indivíduos é submetida ao julgamento, e feita sob os olhos da multidão, juiz [...] com frequência necessariamente justo ${ }^{497}$.

Nesse estado, a virtude e o mérito eram premiados, aliás, era do interesse do "povo" [popolo] premiar os que mereciam, pois eram os seus "servidores" [servitori], e os seus méritos eram considerados "benefícios feitos ao povo" [benefizi fatti al popolo] ${ }^{498}$, encorajando-os aos outros, a fim de imitá$\operatorname{los}^{499}$.

O prêmio da glória cabia às grandes ações, ou seja, "aquele imenso fantasma, aquele estímulo onipotente na sociedade; um estado, do [...] qual cada um sente fazer parte, e ao qual, porém, está afeiçoado e interessado pelo

${ }^{494}$ Ibidem: "soggette a molte calamità, molti dolori, molti mali. Inconvenienti inevitabili nello stesso sistema magistrale della natura; quanto più negli ordini che finalmente sono, più 0 meno, opera umana".

495 LEOPARDI, Giacomo. Zibaldone di pensieri, fragmento 1097, 27.05.1821, in: Tutte le poesie, tutte le prose e lo Zibaldone, p. 1708: "nel bilancio e nell'analisi della massa de' beni e de' mali presso gli uni e presso gli altri".

${ }^{496}$ LEOPARDI, Giacomo. Zibaldone di pensieri, fragmento 565, 22-29.01.1821, in: Tutte le poesie, tutte le prose e lo Zibaldone, p. 1606: "tanta natura, tanta forza di credenze naturali o illusioni, da poter sostenere lo stato democratico, e conseguirne una certa felicità e perfezione di governo".

497 Ibidem: "favorevolissimo alle illusioni, all'entusiasmo [...] uno stato che exige grand'azione e movimento: uno stato dove ogni azione pubblica degl'individui è sottoposta al giudizio, e fatta sotto gli occhi della moltitudine, giudice [...], per lo più necessariamente giusto".

${ }^{498}$ Cf. LEOPARDI, Giacomo. Zibaldone di pensieri, fragmento 565, 22-29.01.1821, in: Tutte le poesie, tutte le prose e lo Zibaldone, p. 1606.

${ }^{499}$ Cf. LEOPARDI, Giacomo. Zibaldone di pensieri, fragmento 565, 22-29.01.1821, in: Tutte le poesie, tutte le prose e lo Zibaldone, p. 1606. 
próprio egoísmo, e como a si mesmo" ${ }^{200}$. Não há o que invejar, porque todos são quase iguais, pois, no entender de Leopardi,

as vantagens são distribuídas equitativamente, as proeminências não são que de mérito e de glória, coisas pouco sujeitas à inveja, pois a estrada para obtê-las está aberta para cada um, e porque não se obtém, a não ser por meio e vontade de cada um e porque redundam em vantagem para a multidão ${ }^{501}$.

Embora não fosse "o estado primitivo da sociedade" [il primitivo stato della societa $]^{502}$ era, no entanto, o estado primitivo do homem, ou seja, do homem "naturalmente livre e senhor de si mesmo, igual aos outros (como qualquer outro animal), e, portanto, bastante da natureza, única fonte de perfeição e felicidade" ${ }^{\text {503 }}$. Enquanto permanecia nesse estado algo natural para sustentá-lo, para que fosse compatível com a sociedade.

Após a "monarquia primitiva", Leopardi reconhece ter sido, porém, o estado mais conveniente ao homem, pois o mais proveitoso "para a vida [e] o mais feliz. Tal estado esteve pouco atrás das repúblicas gregas até as guerras persianas, da romana até as púnicas" ${ }^{\text {"04 }}$. Para Leopardi, a desigualdade é incompatível com aquele estado, cujo princípio é o oposto da unidade, aquele hierárquico, pois se trata aqui de um poder dividido entre cada um, ou seja, a

$\overline{500}$ LEOPARDI, Giacomo. Zibaldone di pensieri, fragmentos 565-566, 22-29.01.1821, in: Tutte le poesie, tutte le prose e lo Zibaldone, p. 1606: "quel fantasma immenso, quella molla onnipotente nella società; uno stato, del [...] quale ciascuno sente di far parte, e al quale però ciascuno è affezionato, e interessato dal proprio egoismo, e come a se stesso".

501 LEOPARDI, Giacomo. Zibaldone di pensieri, fragmento 566, 22-29.01.1821, in: Tutte le poesie, tutte le prose e lo Zibaldone, p. 1607: "i vantaggi sono distribuiti equabilmente, le preminenze non sono che di merito e di gloria, cose poco soggette all'invidia, e perchè la strada per ottenerle è aperta a ciascheduno, e perchè non si ottengono se non per mezzo e volontà di ciascheduno, e perche ridondano in vantaggio della moltitudine".

502 Cf. LEOPARDI, Giacomo. Zibaldone di pensieri, fragmento 566, 22-29.01.1821, in: Tutte le poesie, tutte le prose e lo Zibaldone, p. 1607.

${ }^{503}$ LEOPARDI, Giacomo. Zibaldone di pensieri, fragmento 566, 22-29.01.1821, in: Tutte le poesie, tutte le prose e lo Zibaldone, p. 1607: "naturalmente libero, e padrone di se stesso, e uguale agli altri (come ogni altro animale), e quindi moltissimo della natura sola sorgente di perfezione e felicità".

${ }^{504}$ LEOPARDI, Giacomo. Zibaldone di pensieri, fragmentos 566-567, 22-29.01.1821, in: Tutte le poesie, tutte le prose e lo Zibaldone, p. 1607: "alla vita il più felice. [...] Tale fu appresso a poco lo stato delle repubbliche greche fino alle guerre persiane, della romana fino alle puniche". 
liberdade e a democracia ${ }^{505}$. Daí ser preciso que não haja, entre aqueles em que o poder está dividido, desequilíbrio de poder, isto é, ninguém tenha mais do que o outro. Nesse estado e não em outro é posta, de novo, "a ideia, a essência e o fundamento da liberdade" ${ }^{\text {"506. }}$. Portanto, a liberdade não é mais verdadeira, nem completa ou pode durar na imperfeição, "como a unidade do poder leva o monarca a abusar dele, e passar os limites; assim a maioria do poder, leva o maioria a abusar dele, e buscar aumentá-lo, e assim as democracias vão recair na monarquia" ${ }^{\text {"07 }}$.

O alvo da crítica leopardiana é a monarquia absoluta, até na sua versão "imperial", pois termina puramente nominalista, estando em questão variantes não substanciais dela. Conforme ele argumenta no Zibaldone di pensieri em 1822, os homens se deixam geralmente governar pelos "nomes" [nomi]. Isso decorreria senão de que

as ideias e os nomes estariam tão intimamente ligadas no nosso ânimo, que fazem um todo, e mudado o nome muda-se decididamente a ideia, apesar de o novo nome significar a mesma coisa? Exemplo esplêndido disso foram os romanos, execradores do nome régio, os quais não teriam tolerado um rei chamado rei, o toleravam chamando imperador ${ }^{508}$.

Em verdade, para Leopardi, não há um estado "intolerante com a tirania" [intollerante di tirannia], ou de ela estar ausente, a não ser naquele natural e primitivo, ou em uma "civilização média", como a da Espanha naquele momento, ou a dos romanos, no passado, enquanto Atenas e a Grécia, quando

${ }^{505}$ Cf. LEOPARDI, Giacomo. Zibaldone di pensieri, fragmento 567, 22-29.01.1821, in: Tutte le poesie, tutte le prose e lo Zibaldone, p. 1607.

${ }^{506}$ LEOPARDI, Giacomo. Zibaldone di pensieri, fragmento 567, 22-29.01.1821, in: Tutte le poesie, tutte le prose e lo Zibaldone, p. 1607: "l'idea, l'essenza e il fondamento della libertà".

${ }^{507}$ LEOPARDI, Giacomo. Zibaldone di pensieri, fragmentos 567-568, 22-29.01.1821, in: Tutte le poesie, tutte le prose e lo Zibaldone, p. 1607: "come l'unità del potere porta il monarca ad abusarsene, e passare i limiti; così la maggioranza del potere, porta il maggiore ad abusarsene, e cercare di accrescerlo; e così le [...] democrazie vengono a ricadere nella monarchia".

${ }^{508}$ LEOPARDI, Giacomo. Zibaldone di pensieri, fragmento 2487, 21.06.1822, in: Tutte le poesie, tutte le prose e lo Zibaldone, p. 1523: "le idee e i nomi sono così strettamente legati nell'animo nostro, che fanno un tutt'uno, e mutato il nome si muta decisamente l'idea, benchè il nuovo nome significhi la stessa cosa? Splendidio esempio ne furono i romani, esecratori del nome regio, i quali non avrebbero tollerato un re chiamato re, e lo tollerarono chiamato imperatore". 
já muito civilizada, não foram realmente livres ${ }^{509}$. A tirania decorre apenas de um regime monárquico, por se tratar do governo de um apenas, irrelevante se se trate de um rei ou imperador.

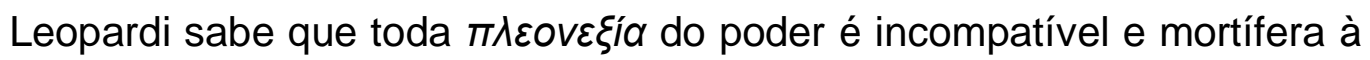
liberdade. Para a liberdade não é preciso nenhuma vantagem de um sobre os outros, senão de mérito e estima, ou seja, de coisas que não despertem inveja nos outros ou que ultrapassem os limites de quem as possui. Quando desaparecem os limites e se buscam vantagens, surgem então "facções, discórdias, partidos, clientelas, rixas, guerras e, ao final, vitória e preponderância de um apenas e monarquia" ${ }^{510}$. Isso justifica, de acordo com Leopardi, a atitude dos antigos legisladores como Licurgo ou dos sábios republicanos, como Fabrício, Catão, pois

proibiam as riquezas, castigavam quem possuía muito mais do que os outros [...] aboliam o saber, as ciências, as artes, a cultura do espírito, em suma toda espécie de $\pi \lambda \varepsilon o v \varepsilon \xi i ́$. Por isso todas as verdadeiras repúblicas e democracias foram pobres e ignorantes até que durou o bem estar delas ${ }^{511}$.

Os atenienses eram também bastante ciumentos do demasiado mérito, da célebre virtude, da mera glória, apesar de privada de honras externas. Para Leopardi, a superioridade do mérito também teve entre os romanos tão pouca sorte, quanto mais era perfeita a democracia, como ocorreu nos primeiros tempos com Coriolano e Camilo. Todavia, com as

riquezas, o luxo, os conhecimentos, a cultura dos engenhos, a desigualdade demasiada das dignidades, e honras exteriores, do poder [...] e só também a desproporção excessiva do mérito e da pura glória,

${ }^{509}$ Cf. LEOPARDI, Giacomo. Zibaldone di pensieri, fragmento 315, 10.11.1820, in: Tutte le poesie, tutte le prose e lo Zibaldone, p. 1558.

${ }^{510}$ LEOPARDI, Giacomo. Zibaldone di pensieri, fragmento 568, 22-29.01.1821, in: Tutte le poesie, tutte le prose e lo Zibaldone, p. 1607: "fazioni, discordie, partiti, clientele, risse, guerre, e alla fine vittoria e preponderanza di un solo, e monarchia".

${ }^{511}$ LEOPARDI, Giacomo. Zibaldone di pensieri, fragmentos 568-569, 22-29.01.1821, in: Tutte le poesie, tutte le prose e lo Zibaldone, p. 1607: "proibivano le ricchezze, gastigavano chi possedeva troppo più degli altri [...] proscrivevano il sapere, le scienze, le arti, la coltura dello spirito, in somma ogni sorta di $\Pi \lambda \varepsilon o v \varepsilon \xi i ́ a$. Perciò tutte le repubbliche e democrazie vere, sono state povere e ignoranti [...] finchè ha durato il loro ben essere". 


$$
\text { pereceram, e sempre pereceram todas as }
$$

Entretanto, como é difícil uma manutenção durável da igualdade perfeita, fundamento essencial e única conservadora indispensável da democracia. Isso explica a impossibilidade desse estado durar longo tempo, terminando naturalmente na monarquia, e com sorte não cair também na oligarquia, no governo dos otimates, isto é, na aristocracia. Contra o risco da desigualdade exagerada e nociva no estado livre, Leopardi indica a "natureza", ou seja,

\begin{abstract}
as ilusões naturais, as quais fazem com que essas desigualdades não se originem senão da virtude e do mérito, e que a virtude e o heroísmo comum da nação, as tolere, aliás as veja com bons olhos, e sem inveja, e com prazer, como resultado do mérito, e não se esforce para atingir aquela superioridade, senão pelos mesmos meios da virtude e do mérito. $E$ que aqueles que conseguiram a dita superioridade, seja de glória, seja de cargos e funções (já que a de riquezas e de outras entre essas vantagens, não tem lugar até que continue a influência da natureza), não abusem delas, não busquem ir além, estejam contentes, aliás empreguem o poder delas para manter a igualdade e liberdade, informem aos outros, diminuam a inveja das vantagens deles fugindo do orgulho, da cobiça, do desprezo ou opressão dos inferiores $[\ldots]^{513}$.
\end{abstract}

512 LEOPARDI, Giacomo. Zibaldone di pensieri, fragmento 569, 22-29.01.1821, in: Tutte le poesie, tutte le prose e lo Zibaldone, p. 1607: "ricchezze, il lusso, le aderenze, la coltura degl'ingegni, la troppa disuguaglianza delle dignità, ed onori esteriori, del potere [...] ed anche la sola eccessiva sproporzione del merito e della pura gloria, perirono, e sempre periranno tutte le democrazie".

${ }^{513}$ LEOPARDI, Giacomo. Zibaldone di pensieri, fragmentos 570-571, 22-29.01.1821, in: Tutte le poesie, tutte le prose e lo Zibaldone, p. 1607: "le illusioni naturali, le quali fanno e che queste disuguaglianze non derivino se non dalla virtù e dal merito, e che la virtù e l'eroismo comune della nazione, le tolleri, anzi le veda di buon occhio, e senza invidia, e con piacere, come effetto del merito, e non si sforzi di arrivare a quella superiorità, se non per lo stesso mezzo della virtù e del merito. $E$ che quelli che hanno conseguita la detta superiorità, sia di gloria, sia di uffizi e dignità (giacchè quella di riccheze, e altri tali vantagi, non ha luogo finchè dura nella [...] repubblica l'influenza della natura), non se ne abusino, non cerchino di passar oltre, sieno contenti, anzi impieghino il poter loro a mantener l'uguaglianza e libertà, si comunichino agli altri, diminuiscano l'invidia de' loro vantaggi col fuggire l'orgoglio, la cupidigia, il disprezzo o l'oppressione degli inferiori [...]". 
Tudo isso acontecia, de acordo com Leopardi, nos primeiros e melhores tempos das democracias antigas, pois foram tempos mais próximos à natureza, para a realização das obras e dos costumes, e materialmente para a idade ${ }^{514}$.

Justamente 0 amor pela liberdade impulsiona Leopardi a diagnosticar as condições que a negam ou que a suprimem. Em qual medida, portanto, a cultura, as luzes podem, igualmente, contribuir com a consolidação da tirania? Daí a sua diagnose dever considerar certas distinções quanto ao grau de civilização atingido. Ele escreve que a tirania "não é jamais segura a não ser quando o povo não é capaz de grandes ações. Disso não pode ser capaz por razão, mas por natureza. Augusto, Luís XIV, e outros tais, mostram de haver bem compreendido essas verdades" ${ }^{\prime 15}$.

Com o desparecimento das illusioni, reduzida ou eliminada a natureza, retornando o baixo egoísmo, estimulado pelas vantagens e pelos meios de ampliação nos superiores, irritando igualmente nos inferiores, pela própria inferioridade, acrescida as riquezas, o luxo, as clientelas, as obrigações, as ambições, a Filosofia, a eloquência e as artes, além de outras expressões da corrupção geral da sociedade, ocorre, em seguida, o enfraquecimento e finalmente a ruína das democracias ${ }^{516}$. Com base nesses argumentos, Leopardi compreende como

os governos que parecem e se encontram [...] muito defeituosos, e por vezes insustentáveis, fossem ou perfeitos, ou bons e também muito úteis no início e durante os costumes naturais. $E$ como não exista peste, nem maior nem mais certa para qualquer estado público, que a corrupção e a extinção da natureza. E como aqueles governos, que continuando a natureza eram bons, cessada a natureza se tornam sem dúvida péssimos. E como à natureza não se pode substituir, e para a falta dela não há remédio algum; nem sem ela

${ }^{514}$ Cf. LEOPARDI, Giacomo. Zibaldone di pensieri, fragmento 571, 22-29.01.1821, in: Tutte le poesie, tutte le prose e lo Zibaldone, p. 1607.

${ }^{515}$ LEOPARDI, Giacomo. Zibaldone di pensieri, fragmento 252, 28.09.1820, in: Tutte le poesie, tutte le prose e lo Zibaldone, p. 1545: "non è mai sicura se non quando il popolo non è mai capace di grandi azioni. Di queste non può esser capace per ragione, mas per natura. Augusto, Luigi 14. ed. Altri tali mostrano di aver bene inteso queste verità".

${ }^{516}$ Cf. LEOPARDI, Giacomo. Zibaldone di pensieri, fragmento 571, 22-29.01.1821, in: Tutte le poesie, tutte le prose e lo Zibaldone, p. 1607. 
se pode jamais esperar perfeição ou felicidade de governo até o final dos séculos ${ }^{517}$.

Para Leopardi, quando se pensa um governo perfeitamente planejado e perfeitamente filosófico será sempre algo muito imperfeito, pois estará repleto de elementos contrastantes, ou seja, mal adequados ao homem, e uma vez que não se pode mais adequar ao homem, quando não é mais o que deveria ser, então será incapaz da verdadeira felicidade. Os vários governos, nos quais vagaram o "espírito humano" [spirito umano], o "acaso" [caso], a "força das circunstâncias particulares" [forza dele circonstanze particolari] serviram apenas, no seu entender, para desesperar os "verdadeiros filósofos" [veri filosofi], e não poucos. Tais "filósofos" estariam convencidos da experiência dessa decorrente imperfeição, infelicidade, contradição e desvantagem de tudo aquilo que "10. carecia de natureza, única norma verdadeira e invariável de toda instituição mundana; $2^{\circ}$. não correspondia à essência e à razão da sociedade, a qual requer a monarquia absoluta" ${ }^{\prime 18}$.

Todas as "aberrações" [aberrazioni] da sociedade, no âmbito dos governos, decaiam, conforme Leopardi, na monarquia, e o mundo nos últimos séculos havia se tornado totalmente monárquico absoluto. Por causa do abuso e corrupção da liberdade e da democracia, decorrentes imediatamente do abuso e corrupção da monarquia absoluta, originava uma nova monarquia absoluta $^{519}$. Trata-se aqui de uma monarquia distinta da primitiva, conveniente à sociedade e sob a influência ainda da natureza, pois representa a ausência da natureza e, por isso, inútil à sociedade, porque se efetiva como tirania.

${ }^{517}$ LEOPARDI, Giacomo. Zibaldone di pensieri, fragmento 572, 22-29.01.1821, in: Tutte le poesie, tutte le prose e lo Zibaldone, pp. 1607-1608: "i governi che paiono e si trovano [...] imperfettissimi, e talora insostenibili, fossero o perfetti, o buoni, ed anche utilissimi da principio, e durante $\mathrm{i}$ costumi naturali. $\mathrm{E}$ come non vi sia peste, nè maggiore nè più certa a qualsivoglia stato pubblico, che la corruzione, e l'estinzione della natura. E come quei governi che durando la natura erano buoni, cessata la natura divengono senz'altro pessime. E come alla natura non si può supplire, e la mancanza di lei non ha rimedio nessuno; nè senza lei si può mai sperare perfezione o felicità di governo fino alla fine dei secoli".

${ }^{518}$ Cf. LEOPARDI, Giacomo. Zibaldone di pensieri, fragmento 573, 22-29.01.1821, in: Tutte le poesie, tutte le prose e lo Zibaldone, p. 1608: "10 mancava di natura sola norma vera e invariabile d'ogni istituzione mondana; $2^{\circ}$ non corrispondeva all'essenza e alla ragione della società, la quale richiede la monarchia assoluta".

519 Cf. LEOPARDI, Giacomo. Zibaldone di pensieri, fragmentos 573-574, $22-$ 29.01.1821, in: Tutte le poesie, tutte le prose e lo Zibaldone, p. 1608. 
Leopardi escreve: "a monarquia absoluta sem natureza, não pode ser outra coisa senão tirania [...] o pior de todos os governos" ${ }^{520}$.

Em seguida, Leopardi explicita os inconvenientes provocados por essa ruína, afirmando que, com a eliminação das

crenças e ilusões naturais, não há razão, não é possível nem humano, que outros sacrifiquem uma mínima vantagem sua para o bem dos outros, coisa essencialmente contrária ao amor próprio, essencial a todos os animais. De maneira que os interesses de todos e de cada um, são sempre, de forma infalível, propostos para aqueles de um apenas, quando eles têm pleno poder de se servir dos outros e das suas coisas, para as vantagens e pensamentos seus, sejam também caprichos, em suma, para qualquer satisfação sua $^{521}$.

O mundo apodreceu logo nesse estado, segundo Leopardi, desde o princípio do império romano até nosso século. Ele escreve que, no último século,

a Filosofia, o conhecimento das coisas, a experiência, o estudo, o exame das histórias, dos homens, os confrontos, os paralelos, o comércio mútuo de toda espécie de homens, de nações, de costumes, as ciências de toda qualidade, as artes etc. têm realizado progressos tais, que todo o mundo esclarecido e instruído, voltou-se a considerar a si mesmo, e o seu estado, e, portanto, principalmente, à política que é a parte mais interessante, mais valiosa, de maior e mais geral influência nas coisas humanas ${ }^{522}$.

$\overline{520}$ LEOPARDI, Giacomo. Zibaldone di pensieri, fragmento 574, 22-29.01.1821, in: Tutte le poesie, tutte le prose e lo Zibaldone, p. 1608: "la monarchia assoluta senza natura, non può esser altro che tirannia [...] il pessimo di tutti i governi".

${ }^{521}$ LEOPARDI, Giacomo. Zibaldone di pensieri, fragmento 574, 22-29.01.1821, in: Tutte le poesie, tutte le prose e lo Zibaldone, p. 1608: "credenze e illusioni naturali, non c'è ragione, non è possibile nè umano, che altri sacrifichi un suo minimo vantaggio al bene altrui, cosa essenzialmente contraria all'amor proprio, essenziale a tutti gli animali. Sicchè gli interessi di tutti e di ciascuno, sono sempre infallibilmente posposti a quelli di un solo, quando questi ha il pieno potere di servirsi degli altri, e delle cose loro, per li vantaggi e piaceri suoi, sieno anche capricci, insomma per qualunque soddisfazione sua".

${ }^{522}$ LEOPARDI, Giacomo. Zibaldone di pensieri, fragmentos 574-575, 22-29.01.1821, in: Tutte le poesie, tutte le prose e lo Zibaldone, p. 1608: "la filosofia, la cognizione delle cose, l'esperienza, lo studio, l'esame delle storie, degli uomini, i confronti, i paralelli, il commercio scambievole d'ogni sorta d'uomini, di nazioni, di costumi, le scienze d'ogni qualità, le arti ec. ec. hanno fatto progressi tali, che tutto il mondo rischiarato e istruito, si è rivolto a considerar se stesso, e lo stato suo, e quindi principalmente [...] alla politica ch'è la parte più interessante, più valevole, di maggiore e più generale influenza nelle cose umane". 
Ademais, a Filosofia, ou seja, a razão humana, avança com todas as suas forças, poder e meios possíveis, e se revela como grande empreendimento, justamente para suprir a natureza perdida e remediar os males que disso se originou: enfim para "reconduzir àquela felicidade perdida há séculos imemoráveis junto com a natureza" ${ }^{23}$. A felicidade, conforme assevera Leopardi, deve ser a finalidade da então nossa perfeita razão, como finalidade também de todas as faculdades e ações humanas.

Ante a ruína da ordem social natural e de suas expressões, Leopardi indaga: "O que saberá fazer essa razão humana vinda totalmente completa em comparação com a natureza, em torno ao ponto principal da sociedade?"524 A França é, em seguida, apresentada como exemplo desse acontecimento. Ao reconhecer a monarquia como indispensável, e a monarquia absoluta, em tudo com a tirania, a Filosofia se arraigou com a condição de apoiar: daí nenhuma ideia de perfeito governo ou de formas essenciais e necessárias de perfeição. Isso justifica, no entender de Leopardi, todo um esforço para reger essa situação:

modificações, acréscimos, distinções, aumentar de uma parte, diminuir de outra, dividir, e depois quebrar a cabeça para equilibrar as partes dessa divisão, tirar daqui, reunir de lá: em suma, reparações miseráveis, escoras, arranjos e chaves, engenhos de toda espécie, para manter um edifício, que perdido o seu bem estar e o seu estado primitivo, não se pode mais se reger sem artifícios que não entrem, de modo nenhum, a ideia primária da sua construção ${ }^{525}$.

${ }^{523}$ LEOPARDI, Giacomo. Zibaldone di pensieri, fragmento 575, 22-29.01.1821, in: Tutte le poesie, tutte le prose e lo Zibaldone, p. 1608: "ricondurre quella felicità ch'è sparita da secoli immemorabili insieme colla natura".

524 Ibidem: "Che saprà fare questa ragione umana venuta finalmente tutta intiera al paragone della natura, intorno al punto principale della società?".

${ }^{525}$ LEOPARDI, Giacomo. Zibaldone di pensieri, fragmento 576, 22-29.01.1821, in: Tutte le poesie, tutte le prose e lo Zibaldone, p. 1608: "Modificazioni, aggiunte, distinzioni, accrescere da una parte, scemare dall'altra, dividere, e poi lambiccarsi il cervello per equilibrare le parti di questa divisione, toglier di qua, aggiunger di là: insomma miserabili risarcimenti, e sostegni, e rattoppature e chiavi, e ingegni d'ogni sorta, per mantenere un edifizio, che perduto il suo ben essere, e il suo stato primitivo, non si può più reggere senza artifizi che non entrano affatto nell'idea primaria della sua costruzione". 
Leopardi alega que a monarquia absoluta houvesse se modificado em vários países, o que acontecerá com toda a Europa, em monarquia constituinte. Contudo, ele acrescenta ainda:

Não nego que no estado presente do mundo civil, esse não seja talvez o melhor partido. Mas, em suma, ela não é uma instituição que tenha o seu fundamento e a sua razão na ideia e na essência ou da sociedade em geral [...] ou do governo monárquico em particular ${ }^{526}$.

Para Leopardi, o estado constitucional não corresponde à natureza e à razão da sociedade em geral, nem, sobretudo, da monarquia. A constituição não seria outra coisa senão um "remédio" [medicina], aplicado e alheio ao corpo doente, embora não sobreviveria sem ele. Daí se compensar a imperfeição, não obstante a constituição ser uma necessária imperfeição do governo. Por conseguinte, é um mal indispensável para remediar ou impedir um mal maior ${ }^{527}$. Trata-se de uma "instituição arbitrária, acessória, derivante dos homens e não das coisas; e, portanto, deve ser necessariamente instável, mutável, incerta e na sua forma, na duração, nas consequências que deveriam emergir dela, para que ela correspondesse à sua finalidade, isto é, à felicidade da nação" ${ }^{28}$.

Nesse sentido, Leopardi conclui o seu argumento sobre os governos defendendo:

como aqueles governos e aquelas coisas de todo gênero, que por princípio e seguindo a natureza, seriam e eram perfeitas, eliminada a natureza, não podem mais sê-lo, não obstante qualquer esforço da razão, do saber, da arte: e essas não podem jamais preencher o lugar da natureza, e fazer a vez dela: aliás,

${ }^{526}$ LEOPARDI, Giacomo. Zibaldone di pensieri, fragmentos 576-577, 22-29.01.1821, in: Tutte le poesie, tutte le prose e lo Zibaldone, p. 1608: "Non nego che nello stato presente del mondo civile, questo non sia forse il miglior partito. Ma insomma questa non è un'istituzione che abbia il suo fondamento e la sua ragione nell'idea e nell'essenza o della società in generale [...], o del governo monarchico in particolare".

${ }^{527}$ Cf. LEOPARDI, Giacomo. Zibaldone di pensieri, fragmento 578, 22-29.01.1821, in: Tutte le poesie, tutte le prose e lo Zibaldone, p. 1609.

${ }^{528}$ LEOPARDI, Giacomo. Zibaldone di pensieri, fragmento 577, 22-29.01.1821, in: Tutte le poesie, tutte le prose e lo Zibaldone, p. 1608: "istituzione arbitraria, ascitizia, derivante dagli uomini e non dalle cose: e quindi necessariamente dev'essere istabile, mutabile, incerta e nella sua forma, e nella durata, e negli effetti che ne dovrebbero emergere perch'ella corrispondesse al suo scopo, cioè alla felicità della nazione". 
remediando a um mal, introduzem necessariamente um outro ${ }^{529}$.

Daí ele reconhecer como algo já demonstrado, quer pela razão quer pela experiência, pela história e pelo conhecimento do homem, em qualquer sociedade e, em especial, aquelas civis, sobretudo, as mais civis, que todas as constituições tendem a cair continuamente na monarquia, mais cedo ou mais tarde:

qualquer que seja a constituição política delas, caem inevitavelmente, e quando também renascem, pouco dura o renascimento e pouco favorece, e que, em suma, na sociedade não há nela, nem pode haver estado político durável senão o monárquico absoluto ${ }^{530}$.

Para Leopardi, a liberdade permanece como algo possível apenas do "estado natural e primitivo" [stato naturale e primitivo] ${ }^{531}$, ou de uma "civilização média" [civilizzazione media]. Observando certo arco do desenvolvimento histórico, ele limita ao extremo o espaço temporal relativo à liberdade. $\mathrm{Na}$ Antiguidade a época feliz se encerra com as Filippiche de Cícero, e não ressurge mais, a não ser no sentido programático com a França republicana. Nesse sentido, a liberdade romana "expirou para sempre a liberdade das nações civilizadas", e esse culto ressurgiu com os escritores "franceses de ultimamente" ${ }^{232}$.

A última "voz romana" ou "último monumento da liberdade antiga" está representado nas Filippiche ciceronianas. Ao observar com insistência a história romana, Leopardi destaca uma frase de Floro sobre Antônio - "corrupto

${ }^{529}$ LEOPARDI, Giacomo. Zibaldone di pensieri, fragmento 579, 22-29.01.1821, in: Tutte le poesie, tutte le prose e lo Zibaldone, p. 1609: "come quei governi e quelle cose d'ogni genere, che da principio e secondo natura, sarebbero ed erano perfette, tolta la natura, non possono più esserlo malgrado qualunque sforzo della ragione, del sapere, dell'arte: e queste non possono mai riempiere il luogo della natura, e fare perfettamente le di lei veci: anzi rimediando a un male, ne introducono necessariamente un altro".

${ }^{530}$ LEOPARDI, Giacomo. Zibaldone di pensieri, fragmento 3082, 02.08.1823, in: Tutte le poesie, tutte le prose e lo Zibaldone, p. 2063: "qualunque sia la loro politica costituzione, vi cadono inevitabilmente, e quando anche ne risorgono, poco dura il risorgimento e poco giova, e che insomma nella società non havvi nè vi può avere stato polico durabile se non il monarchico assoluto".

${ }^{531}$ Cf. LEOPARDI, Giacomo. Zibaldone di pensieri, fragmento 315, 10.11.1820, in: Tutte le poesie, tutte le prose e lo Zibaldone, p. 1558.

532 Cf. LEOPARDI, Giacomo. Zibaldone di pensieri, fragmento 459, 27.12.1820, in: Tutte le poesie, tutte le prose e lo Zibaldone, pp. 1587-1588. 
e depravado" triúnviro -, pois não seria possível outra alternativa senão a do "senhor e do servo". Leopardi exprime a sua consciência moral na compreensão de que todo aquele dominado pelo egoísmo, ignora as grandes paixões, a magnanimidade, o entusiasmo, reconhecendo apenas o "servir ou reinar" ${ }^{533}$. Trata-se, aqui, de uma verdade conduzida para a realidade éticopolítica do presente: a realidade de grande parte dos homens hoje.

Por isso, a sua defesa de que um "estado de perfeita liberdade e igualdade" é aquele no qual o indivíduo se afirma, que possui "qualidades reais", ou seja, objetivas, válidas, conforme "as regras e as opiniões universais", as únicas verdadeiras. Aqueles que não possuem virtudes e qualidades autênticas - "tais são os homens corruptos" - não podem "suportar a liberdade e a igualdade, nem encontrar vida nesse estado" 534 .

Revela-se nos argumentos de Leopardi a sua preferência por um governo democrático, ou seja, fundado na liberdade e igualdade e, portanto, um governo republicano, mesmo que sujeito à decadência. Contudo o Zibaldone di pensieri revela o teor da recusa leopardiana à monarquia absoluta, considerada o pior de todos os governos, algo que não ocorria na sua origem, ou seja, como monarquia primitiva. A crítica leopardiana se fundamenta no princípio de "unidade" sobre o qual deve se apoiar a sociedade, compreendida aqui como união de muitos visando ao bem comum. A falta da liberdade e da igualdade ocorre, no entender de Leopardi, quando na inevitável diferenciação dos interesses, vontades e opiniões, os quais prejudicariam a realização, ocorre a subordinação à vontade, aos interesses e opiniões de um apenas.

Destaca-se, portanto, na ênfase republicana da reflexão de Leopardi sobre a organização política da sociedade e sobre a questão da Modernidade, a sua preocupação com a liberdade e igualdade, ante os limites estabelecidos pela sociedade e os obstáculos que nela se põem, interpondo-se à completa integração do indivíduo. A república se apresenta como a única via para que

${ }^{533}$ Cf. LEOPARDI, Giacomo. Zibaldone di pensieri, fragmentos 523-524, 18.01.1821, in: Tutte le poesie, tutte le prose e lo Zibaldone, p. 1599.

${ }^{534}$ LEOPARDI, Giacomo. Zibaldone di pensieri, fragmento 525, 18.01.1821, in: Tutte le poesie, tutte le prose e lo Zibaldone, p. 1600: "sopportare la libertà e l'uguaglianza, nè trovar vita in questo stato". 
seja apropriada de novo a liberdade, ultrapassando assim as resistências. Embora o estado perfeito permaneça sempre naquela primeira infância da sociedade, onde ela é, antes, uma reunião material de homens que uma sociedade.

Isso pressupõe também a consciência moral de Leopardi e a sua observação dos exemplos históricos que revelam a presença da corrupção, pois estava consciente de que a "corrupção dos costumes é mortal às repúblicas, e útil às tiranias e monarquias absolutas" ${ }^{535}$. Na sua interpretação das monarquias, Leopardi as identifica, mesmo se tratando de monarquias antigas, absolutas e despóticas, com as monarquias contemporâneas, não obstante se denominarem ducados, grão-ducados, reinos ou estados, nas quais a Itália se apresentava fragmentada, ou a situação de seu país no presente, como refletiu no Discorso de 1824. Trata-se também de sua contestação do mundo moderno, pois dominado pelo egoísmo que suprime liberdade e igualdade. Ademais, se pressupõe nessas suas análises do presente e da antinomia monarquia-república, aquela análise de passadopresente na qual certo passado ideal, o da proximidade da natureza e das ilusões, se revela como denúncia do strage delle illusioni.

\subsection{Modernidade e processo de espiritualização das coisas}

\section{humanas}

A reflexão de Leopardi sobre a razão e, sobretudo a razão moderna, serve aqui de pressuposto para uma abordagem no universo temático de sua obra, o que represente, no processo da modernização e da história da civilização, a "espiritualização das coisas humanas" [spiritualizzazione delle cose umane]. Leopardi a define tal espiritualização como "miserável", por reconhecer consequências nefastas, sobretudo, quando estão em questão as expressões anteriores do ethos antigo. Para Leopardi, a

mísera espiritualização das coisas humanas, derivada da experiência, do conhecimento tão propagado e aumentado, pela razão e do exílio da natureza, única

535 LEOPARDI, Giacomo. Zibaldone di pensieri, fragmento 302, 3.11.1820, in: Tutte le poesie, tutte le prose e lo Zibaldone, p. 1555: "corruttela dei costumi è mortale alle repubbliche, e utile alle tirannie, e monarchie assolute". 
mãe da vida, e do fazer. Consequência que se pode estender a coisas muito mais gerais, e achá-la igualmente verdadeira, tanto na teoria, quanto na prática. De cuja espiritualização que é quase o mesmo que a anulação, decorre que hoje em lugar de fazer, deva-se computar; e lá onde os antigos faziam as coisas, os modernos as contam; e os resultados uma vez das ações, hoje sejam resultados dos cálculos, e assim sem fazer nada, viva-se calculando e computando aquilo que se deve fazer, ou que deva suceder; esperando de fazer efetivamente, e por conseguinte de viver, quando estaremos mortos. Já que agora uma tal vida não se pode distinguir da morte, e deve ser necessariamente um todo com esta ${ }^{536}$.

Observando as circunstâncias presentes, ou seja, aquelas modernas, Leopardi as identifica como "tão favoráveis à reflexão e à investigação dos abstratos, [os quais] não são naturais" ${ }^{\text {"337. }}$. A natureza havia, portanto, muito bem provido ao estado social do homem, "também daquelas verdades que deviam servir a esse estado, e the servir de base; verdades tão conhecidas pelos antigos, tão menos profundos do que nós" ${ }^{238}$. Os modernos se valem das "verdades abstratas" [verità astratte] ${ }^{539}$ daí Leopardi indagar: "quando também em um excesso de metafísica, a mente humana não se perde?"540 Isso porque, em consonância com a sua diagnose do mundo moderno e de certa compreensão dos rumos da individualidade, Leopardi exclama: "Quanto eram

${ }^{536}$ LEOPARDI, Giacomo. Zibaldone di pensieri, fragmentos 1106-1107, 01.05.1821, in: Tutte le poesie, tutte le prose e lo Zibaldone, p. 1689: "misera spiritualizzazione delle cose umane, derivata dall'esperienza, dalla cognizione sì propagata e cresciuta, dalla ragione, e dall'esilio della natura, sola madre della vita, e del fare. Conseguenza che si può estendere a cose molto più generali, e trovarla egualmente vera, sì nella teorica, come nella pratica. Dalla quale spiritualizzazione che è quasi lo stesso coll'annullamento, risulta che oggi in luogo di fare, si debba computare; e laddove gli antichi facevano le cose, i moderni le contino; e i risultati una volta delle azioni, oggi sieno [...] risultati dei calcoli; e così senza far niente, si viva calcolando e supputando quello che si debba fare, o che debba succedere; aspettando di fare effetivamente, e per conseguenza di vivere, quando saremo morti. Giacchè ora una tal vita non si può distinguere dalla morte, e dev'essere necessariamente tutt'uno con questa".

${ }^{537}$ LEOPARDI, Giacomo. Zibaldone di pensieri, fragmento 1354, 20.07.1821, in: Tutte le poesie, tutte le prose e lo Zibaldone, p. 1766: "sì favorevoli alla riflessione, e alla investigazione degli astratti, [che] non sono naturali".

${ }^{538}$ Ibidem: "anche a quelle verità che dovevano giovare a questo stato, e servirgli di base; verità ben note agli antichi, tanto meno profondi di noi".

${ }^{539}$ Cf. LEOPARDI, Giacomo. Zibaldone di pensieri, fragmento 1354, 20.07.1821, in: Tutte le poesie, tutte le prose e lo Zibaldone, p. 1766.

${ }^{540}$ LEOPARDI, Giacomo. Zibaldone di pensieri, fragmento 1354, 20.07.1821, in: Tutte le poesie, tutte le prose e lo Zibaldone, p. 1766: "quando anche in un ecesso di metafisica, la mente umana non si smarrisse?" 
mais úteis aquelas verdades que eu estabelecia acerca da política [...], as quais me traz o avanço e o andamento natural e aguçamento sucessivo do meu intelecto!" 541

Reporta-se, em seguida, à experiência filosófica dos antigos e da razão, na expressão filosófica dessa época da humanidade, defendendo, em oposição à Modernidade, à ratio moderna, de se poder

dizer que a Filosofia (compreendendo a moral que é a mais e talvez a única útil) era, quanto à utilidade, já perfeita no tempo de Sócrates que foi o primeiro filósofo das nações bem conhecidas; ou queremos dizer no tempo de Salomão ${ }^{542}$.

Embora na Modernidade, a moral tivesse avançado tanto, no entender de Leopardi, "não é mais perfeita, aliás, menos [perfeita], porque exagerada, e, portanto, ela também corrompida, corrompida também a razão, como a civilização e a natureza" ${ }^{\text {543 }}$.

O processo civilizatório revela ainda na Modernidade, e com a espiritualização das coisas, outro acontecimento na dimensão antropológica e no seu desenvolvimento. Trata-se da presença do "sentimental" [sentimentale] e do "amor espiritual" [amore spirituale], sem descurar do que se percebe no pensamento a que este se reporta. Porque, escreve Leopardi,

os homens civilizando-se cada vez mais e sempre com a mesma proporção adquirindo e aumentando a sua consistência, em eficácia, valor, importância, em extensão, atividade, influência, força e poder, faculdade, a parte espiritual e interna do homem, chegou-se primeiramente a reconhecer e supor no homem uma parte oculta e invisível que os primitivos ou não supunham, de modo nenhum, ou muito levemente, e pouco distintamente pela parte visível e

541 Ibidem: "Quanto erano più utili quelle verità che io stabiliva circa la politica [...], alle quali ora mi porta l'avanzamento, e il naturale andamento e assottigliamento sucessivo del mio intelletto!".

542 Ibidem: "dire che la filosofia (intendendo la morale ch'è la più, e forse la sola utile) era, quanto all'utilità, già perfetta al tempo di Socrate che fu il primo filosofo delle nazioni ben conosciute; o vogliamo dire al tempo di Salomone".

543 Ibidem: "non è più perfetta, anzi meno, perchè soverchia, e quindi corrotta anch'essa, corrotta ache la ragione, come la civiltà e la natura". 
sensível; em seguida considerá-la igualmente como a parte exterior ${ }^{544}$.

$\mathrm{Na}$ continuidade desse processo de civilização, cada vez mais se acirra a espiritualização. Daí Leopardi reconhecer no mundo moderno, no homem e em cada indivíduo humano:

se a natureza não repugnasse (a qual no último [...] não pode ser jamais extinta totalmente) pelo menos quase se consideraria que o interior, e para o homem não se compreenderia em nenhum caso, outra coisa senão o seu espírito ${ }^{545}$.

Em seguida ele destaca, considerando a presença do "sentimental", e na proporção do processo de

espiritualização do amor, a qual o torna [o amor] o campo e a fonte de ideias mais vagas e de sentimentos mais indefinidos que não desperta talvez nenhuma paixão, não obstante ela, na origem, e também hoje em dia, quanto a sua finalidade, seja talvez, ao mesmo tempo, [...] a mais material e a mais determinada das paixões, comum quanto a sua natureza, aos animais e aos homens os mais brutais e estúpidos e que menos participam do espírito ${ }^{546}$.

Desde quando a "espiritualização das coisas humanas" atingiu o seu ápice, que Leopardi identifica na sua época,

tornou-se pela primeira vez comum aquele amor que com o novo nome, como nova coisa, se chamou

544 LEOPARDI, Giacomo. Zibaldone di pensieri, fragmento 3910, 26.11.1823, in: Tutte le poesie, tutte le prose e lo Zibaldone, p. 2228: "gli uomini civilizzandosi di più in più, e sempre colla stessa proporzione acquistandone ed aumentandosene di consistenza, di efficacia, di valore, d'importanza, di estensione, di attività, d'influenza, forza, e potere, di facoltà, la parte spirituale ed interna dell'uomo, si è venuto primieramente a riconoscere e supporre nell'uomo una parte nascosta e invisibile che i primitivi o non supponevano affatto o molto leggieramente, e poco distintamente dalla parte visibile e sensibile; poscia a considerarla altrettanto quanto la parte esteriore".

${ }^{545}$ LEOPARDI, Giacomo. Zibaldone di pensieri, fragmentos 3910-3911, 26.11.1823, in: Tutte le poesie, tutte le prose e lo Zibaldone, p. 2228: "se la natura non ripugnasse (la quale all'ultimo [...] non può mai totalmente essere nè spenta nè superata) non altro quasi si considererebbe che l'interiore, e per uomo non s'intenderebbe in nessun caso altro che il suo spirito".

${ }^{546}$ LEOPARDI, Giacomo. Zibaldone di pensieri, fragmento 3911, 26.11.1823, in: Tutte le poesie, tutte le prose e lo Zibaldone, p. 2228: "spiritualizzazione dell'amore, la quale lo rende il campo e la fonte di più idee vaghe, e di sentimenti più indefiniti forse che non ne desta alcun'altra passione, non ostante che'esso e in origine, e anche oggidì quanto al suo fine, sia forse nel tempo stesso [...] la più materiale e la più determinata delle passioni, comune, quanto alla sua natura, alle bestie, ed agli uomini i più bestiali e stupidi ec. e che meno partecipano dello spirito". 
sentimental; aquele amor do qual os antigos mal tiveram ideia, ou que sob o nome de platônico, aparecendo às vezes em algum raro espírito, ou se discutindo [sobre ele] entre os filósofos e os escolásticos, tem sido considerado até hoje ou uma fábula, um ente de razão e quimérico, ou um milagre, coisa repugnante à natureza universal, ou um impossível, ou uma coisa muito extraordinária, ou uma palavra vazia de sentido, e uma ideia confusa ${ }^{547}$.

Tal ideia permanecia ainda, conforme Leopardi, muito confusa, pois mais invocada do que concebida pelos filósofos e "pelos mais sábios [...] ridicularizada e considerada de jamais se tornar [...] clara" ${ }^{n 48}$. Por isso, essa espiritualização excessiva do amor, à qual com vocábulo próprio chamam de "amor sentimental [amore sentimentale], "responde à suprema espiritualização das coisas humanas, que nesses últimos tempos teve e tem lugar" ${ }^{249}$.

Como da espiritualização crescente das coisas humanas se origina também a espiritualização do amor, e sempre e na exata proporção cresce, atingindo assim o seu ápice, Leopardi reflete então sobre as relações de gênero. Ele considera a expressão vaga e indefinida "dessa paixão e dos sentimentos de um sexo com o outro" [di questa passione e de' sentimenti dell'un sesso verso l'altro] ${ }^{50}$, como algo claro e fácil de ser explicado, de acordo com o que foi já anteriormente exposto. Reportando-se ao homem e à mulher, ele reconhece que no início, como ocorria em si mesmo, mas também nos outros homens e naturalmente também na mulher e vice-versa, não consideravam senão o exterior, "mas com o início da civilização, nascendo a

${ }^{547}$ LEOPARDI, Giacomo. Zibaldone di pensieri, fragmento 3911, 26.11.1823, in: Tutte le poesie, tutte le prose e lo Zibaldone, pp. 2228-2229: "si è reso per la prima volta comune quell'amore che con nuovo nome, siccome nuova cosa, si è chiamato sentimentale; quell'amore di cui gli antichi non ebbero appena idea, o che sotto il nome di platonico, apparendo talora in qualche raro spirito, o disputandosene tra' filosofi e gli scolastici, è stato finora riputato o una favola e un ente di ragione e chimerico, o un miracolo, e cosa ripugnante alla universal natura, o un impossibile, o una cosa straordinarissima, o una parola vuota di senso, e un'idea confusa".

${ }^{548}$ LEOPARDI, Giacomo. Zibaldone di pensieri, fragmento 3911, 26.11.1823, in: Tutte le poesie, tutte le prose e lo Zibaldone, p. 2229: "da' più savi [...] derisa e stimata incapace di mai divenir [...] chiara".

549 LEOPARDI, Giacomo. Zibaldone di pensieri, fragmento 3912, 26.11.1823, in: Tutte le poesie, tutte le prose e lo Zibaldone, p. 2229: "risponde alla suprema spiritualizzazione delle cose umane, che in questi ultimi tempi ebbe ed ha luogo".

${ }^{550}$ Cf. LEOPARDI, Giacomo. Zibaldone di pensieri, fragmento 3912, 26.11.1823, in: Tutte le poesie, tutte le prose e lo Zibaldone, p. 2229. 
ideia de espírito, por causa da força e ação que a parte interna começava a adquirir e desenvolver, e aos poucos, como essa parte do exterior, assim a ideia do espírito naquela do corpo, antes se igualando, e pouco a pouco excessivamente prevalecendo, o indivíduo de uma sexo naquele do outro, teve necessariamente primeiro começado a considerar também o espírito, e depois seguindo, considera-lo quanto ao corpo, e finalmente mais do que o corpo mesmo, pelo menos em certo sentido e modo" ${ }^{51}$.

Desse processo do exterior para o interior, após a ideia de espírito, ocorreu, de acordo com Leopardi, que "o objeto amável de um sexo foi para o indivíduo do outro, não mais um objeto simplesmente material, como no início, mas um objeto composto de espírito e corpo, com parte oculta e com parte evidente, e em seguida, aos poucos, um objeto mais espiritual do que material, mais oculto e imaginável do que evidente e sensível, mais interior que exterior" ${ }^{\prime 52}$. Em seguida, ele aprofunda a sua análise dessa mudança, revelando o teor dessa espiritualização: como as ideias que tem relação com a parte interna e oculta do homem são naturalmente vagas e muitas, logo a ideia do objeto amável, considerado no dito modo, começou necessariamente a participar do misterioso, unindo-se nessa ideia a consideração do espírito àquela do corpo; e conseguindo aos poucos a primeira consideração [primazia] sobre a segunda, cada vez mais misteriosa devia se tornar a ideia do objeto amado, até possuir finalmente mais do místico, do incerto e do vago, que do claro e determinado.

Trata-se aqui de um processo em que os sentimentos e ideias, pertencentes à paixão do amor, buscam cada vez mais aquilo que tem de mais

${ }^{551}$ LEOPARDI, Giacomo. Zibaldone di pensieri, fragmento 3912, 26.11.1823, in: Tutte le poesie, tutte le prose e lo Zibaldone, p. 2229: "Ma col principiar della civilizzazione, nascendo l'idea dello spirito, a causa della forza ed azione che la parte interna incominciava ad acquistare e sviluppare, e di mano in mano, come questa parte all'esterna, così l'idea dello spirito a quella del corpo, prima agguagliandosi, e poi apocco a poco strabocchevolmente prevalendo, l'individuo dell'un sesso in quello dell'altro dovette necessariamente prima incominciare a considerare anche lo spirito, e poi seguendo, considerarlo quanto il corpo, e finalmente più del corpo medesimo, almeno in un certo senso e modo".

552 LEOPARDI, Giacomo. Zibaldone di pensieri, fragmentos 3912-3913, 26.11.1823, in: Tutte le poesie, tutte le prose e lo Zibaldone, p. 2229: "l'oggetto amabile dell'un sesso fu all'individuo dell'altro, non più un oggetto semplicemente materiale, come in principio, ma un oggetto composto di spirito e di corpo, di parte occulta e di parte manifesta, e poscia di mano in mano un oggetto più spirituale che $[. .$.$] materiale, più occulto e immaginabile che manifesto e$ sensibile, più interiore che esteriore". 
"indefinido" [indefinito]. Isso ocorre na proporção que avança o processo de civilização, na qual essa paixão se torna incomparavelmente mais deleitável. Por isso, o princípio do amor, embora seja hoje necessariamente, conforme escreve Leopardi, aquilo que foi nos primitivos, nos selvagens, e que sempre foi nos brutos, igualmente material e animal, apresenta certa singularidade. Essa paixão, juntando em si o espiritual com o material, tornou-se assim diferente daquela, em que certamente o amor propriamente sentimental não parece ter nenhuma relação, nem com o amor dos selvagens, nem com aquele dos brutos, mas ser por natureza princípio e por origem totalmente diferente e distinto. Ademais, mesmo o amor, o menos platônico e o mais sensual, assegura Leopardi, tem na Modernidade, necessariamente, quer nas suas ideias quer nos seus sentimentos, bastante do "espiritual" [spirituale] e, portanto, do imaginável, do vago e indefinido no objeto amado ou desfrutado.

Para Leopardi são várias as causas, de natureza e princípio totalmente alheias e extrínsecas aos próprios sujeitos, que influenciam, nesse processo de espiritualização das coisas humanas, situações particulares de amor e sentimentos de um sexo para com o outro, pois o corporal tomará a forma da coisa mais espiritual no mundo. Mesmo uma pessoa mais rude e inculta, destaca Leopardi, considera de qualquer maneira:

uma parte oculta desse objeto [amado] que acompanha e anima, e pertence intimamente, abraça e está unida àquela parte e àqueles membros como amáveis e desejáveis; porque aquela parte de fato existe, e tem grandíssima parte no ser daquele objeto, e o interior é uma porção muito grande disso, por brutal ou insensato que seja esse também; e o amante o vê bastante todos os dias ${ }^{553}$.

Tratando-se de "objetos amados" [oggetti amati] e de "amantes" [amanti], não obstante brutos ou incultos, existindo pouco para o espírito, são assim mesmo "civilizados" [civill]. Ao retornar ainda ao argumento da imaginação e de

553 LEOPARDI, Giacomo. Zibaldone di pensieri, fragmento 3913, 26.11.1823, in: Tutte le poesie, tutte le prose e lo Zibaldone, p. 2229: "una parte occulta di esso oggetto che accompagna ed anima e strettamente appartiene, abbraccia ed è congiunta a quella parte e a quelle membra che egli desidera, o ch'ei si gode, o ch'ei riguarda come amabili e desiderabili; perchè in fatti quella parte vi è, ed ha grandissima parte nell'essere di quell'oggetto, e l'interno è una grandissima porzione di questo, per brutale o insensato che anch'esso di sia; e l'amante il vede assai bene tottodi". 
outro "mistério particular" [mistero particolare], Leopardi assegura que influencie e modifique bastante,

também o amor o mais corporal para com os indivíduos particulares de outro sexo (ou também do mesmo sexo, segundo o uso dos gregos), assim essa imaginação e o mistério geral decorrente do uso das vestimentas, influenciou no modo que [...] influencia geralmente sobre o amor e os sentimentos (mesmo os mais materiais por princípio, por finalidade) de um sexo em relação ao outro, considerado tudo junto ${ }^{554}$.

Aquilo que ocorre no universo da consideração do espírito, ou seja, como "coisa oculta" [cosa oculta] de influência sobre o corpo, tornando assim "misteriosos e vagos" [misteriosi e vaghi] sentimentos e ideias que têm origem naturalmente nele, e abertamente ou de imediato se lhe reportam, do mesmo modo, Leopardi escreve:

a consideração do corpo tornado ele também coisa, na sua maior parte, oculta e sujeita à imaginação alheia mais que aos sentidos, torna misteriosos etc. e espiritualiza, no modo mais natural, os sentimentos e as ideias [...]: e de uma causa, totalmente, muito material nasce [...] um resultado que tem do muito espiritual, do simplesmente espiritual, do mais espiritual que qualquer outro, $[. . .]^{555}$.

Nessa reflexão de Leopardi sobre a espiritualização do homem e as suas consequências, tanto no ânimo quanto no conhecimento da verdade, revela-se a sua ideia de que são coisas, em parte necessárias, e, em parte consequências, mas também "substância" [sostanza] ou sinônimos dela, do estado do homem civilizado. Esse estado, entretanto, é concebido por Leopardi como algo, sem dúvida, mais inferior do que aqueles das sociedades "mais

${ }^{554}$ LEOPARDI, Giacomo. Zibaldone di pensieri, fragmento 3914, 26.11.1823, in: Tutte le poesie, tutte le prose e lo Zibaldone, p. 2229: "l'amore anche il più corporale verso gl'individui particolari d'altro sesso (o anche del medesimo sesso, secondo l'uso de' greci), così l'immaginazione e il mistero generale derivante dall'uso delle vesti, influì nel modo che si è detto nel pensiero a cui questo si riferisce, e sempre e del continuo influisce generalmente sopra l'amore e i sentimenti (anche i più materiali per principio, per iscopo ec.) dell'un sesso verso l'altro, considerato tutto insieme".

${ }^{555}$ LEOPARDI, Giacomo. Zibaldone di pensieri, fragmentos 3914-3915, 26.11.1823, in: Tutte le poesie, tutte le prose e lo Zibaldone, p. 2229: "la considerazione del corpo divenuto anch'esso cosa, per la maggior sua parte, occulta e sottoposta all'immaginazione altrui più ch'ai sensi, rende misteriosi ec. e spiritualizza nel modo il più naturale i sentimenti e le idee ec.: e da una causa tutta materialissima nasce [...] un effetto che ha dello spiritualisssiimo, del semplicemente spirituale, del più spirituale ch'alcuno altro ec." 
selvagens e brutais" [selvagge e brutall] ${ }^{56}$. Por ser o estado do homem civilizado mais distante da natureza, ocorre ser infinitamente mais infeliz.

Nesse estado civilizado, a convivência entre os indivíduos apresenta certas características singulares, próprias da constituição e natureza desse estado, ou seja, o indivíduo, no entender de Leopardi, na sociedade civil

prejudica menos aos outros, mas muito mais a si mesmo. E também, quanto aos outros, ele prejudica menos ao físico deles, mas muito mais ao moral, ele os lesa menos fisicamente, mas moralmente de mil maneiras e sob mil considerações, muito além ${ }^{557}$.

Para Leopardi, o "moral" no homem civil, ou seja, o espírito e o que dele se origina, é, pela própria natureza do homem em tal estado,

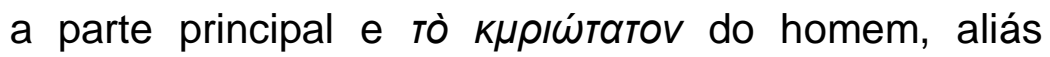
quase todo homem, não de outro modo e nada menos [...] que no homem primitivo ou de sociedade selvagem, a parte principal, e quase o todo, seja o corpo ${ }^{558}$.

Por conseguinte, os indivíduos, na sociedade civil, ao prejudicarem os seus semelhantes moralmente, bem mais que na sociedade selvagem, contribuem "para a infelicidade do espírito de uns e de outros, eles não se prejudicam mutuamente menos, nem causam um ao outro menos infelicidade, nem dessa eles são menos motivo, daquilo que ocorre na sociedade bárbara, onde o prejuízo mútuo, e a infelicidade que decorre da própria sociedade é mais física que moral, porque os seus subjugados, isto é, aqueles homens são do mesmo modo mais matéria que espírito na mesma proporção. Quando a infelicidade do espírito é maior que a do corpo, maior é, segundo Leopardi, o "dano moral" [danno morale] ${ }^{559}$ e influindo, em especial, sobre o "moral": algo

${ }^{556}$ Cf. LEOPARDI, Giacomo. Zibaldone di pensieri, fragmento 3932, 28.11.1823, in: Tutte le poesie, tutte le prose e lo Zibaldone, p. 2234.

${ }^{557}$ LEOPARDI, Giacomo. Zibaldone di pensieri, fragmento 3932, 28.11.1823, in: Tutte le poesie, tutte le prose e lo Zibaldone, p. 2234: "nella società civile nuoce meno agli altri, ma molto più a se stesso. Ed anche quanto agli altri, ei nuoce meno al lor fisico ma al morale molto più, ei li danneggia fisicamente meno, ma moralmente in mille guise e sotto mille rispetti, molto davantaggio".

${ }^{558}$ LEOPARDI, Giacomo. Zibaldone di pensieri, fragmentos 3932-3933, 28.11.1823, in:

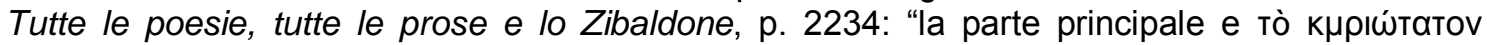
dell'uomo, anzi quase il tutto l'uomo, non altrimenti e niente manco [...] che nell'uomo primitivo o di società salvatica, la parte principale e quasi il tutto, sia il corpo".

${ }^{559}$ Cf. LEOPARDI, Giacomo. Zibaldone di pensieri, fragmento 3933, 28.11.1823, in: Tutte le poesie, tutte le prose e lo Zibaldone, p. 2234. 
que aflige os homens civilizados mesmo quando ofendem a coisas e por meio físicos. Na sociedade civilizada, ou seja, aquela civil é grande a infelicidade que os indivíduos arranjam para si, mais do que as "sociedades bárbaras, ou semibárbaras, ou semicivilizadas em proporção" 560 .

Nenhuma "sociedade selvagem" [società selvaggia] se prejudica moralmente como ocorre na civil. Mesmo os prejuízos contra o físico ocorrem por acidente, pois os civilizados chegam até o suicídio ${ }^{561}$. Leopardi conclui a sua análise dos danos morais na sociedade civilizada, reconhecendo que em tal sociedade, não obstante ser menor a infelicidade física, ou melhor, os infortúnios físicos, uma vez que ela lá prejudica geralmente o físico, sobretudo, por causa das doenças, as quais decorrem dessa sociedade civilizada, mesmo com maiores infortúnios morais, maior é também a infelicidade, pois se trata do "mal civilizado" [mal civill]: isto é o mal de sua própria natureza ${ }^{562}$.

A sociedade civilizada já se encontra muito distante da natureza, embora as "crueldades" [snaturatezze] da sociedade selvagem sejam mais perceptíveis, mas por causa de sua natureza material e física. Para Leopardi não existe algo mais contra a natureza do que

\begin{abstract}
aquela espiritualização das coisas humanas e do homem, que é companheira essencial, consequência, substância da civilização. Como as crueldades, as calamidades e a infelicidade das sociedades selvagens, por serem naturalmente mais físicas, aliás todas físicas e materiais, são mais evidentes e tais que cada um pode reconhecê-las por aquilo que são, não existe homem, o qual não concordasse que se a sociedade humana não pudesse ser outra senão a selvagem, a sociedade no nosso gênero seria algo contra a natureza, e o homem não ser feito para a sociedade, e [nela] ser necessariamente muito imperfeito e muito infeliz ${ }^{563}$.
\end{abstract}

${ }^{560}$ Cf. LEOPARDI, Giacomo. Zibaldone di pensieri, fragmento 3933, 28.11.1823, in: Tutte le poesie, tutte le prose e lo Zibaldone, p. 2234: "società barbare, o semibarbare, 0 semicivili, a proporzione".

${ }^{561}$ Cf. Cf. LEOPARDI, Giacomo. Zibaldone di pensieri, fragmento 3933, 28.11.1823, in: Tutte le poesie, tutte le prose e lo Zibaldone, p. 2235.

${ }^{562}$ Cf. LEOPARDI, Giacomo. Zibaldone di pensieri, fragmento 3934, 28.11.1823, in: Tutte le poesie, tutte le prose e lo Zibaldone, p. 2235.

${ }^{563}$ LEOPARDI, Giacomo. Zibaldone di pensieri, fragmento 3934, 28.11.1823, in: Tutte le poesie, tutte le prose e lo Zibaldone, p. 2235: "quella spiritualizzazione delle cose umane e 
No entanto, ocorre algo contrário e justamente por causa da natureza da sociedade civilizada e de sua espiritualização. Leopardi sabe que os danos e as crueldades da sociedade civilizada são mais morais e espirituais, ou seja, algo adequado à natureza dessa sociedade e ao "homem civilizado" [uomo civile], não podendo ser diferente, por isso,

conquanto tais danos sejam realmente muito mais graves realmente, e contra a natureza, e tais crueldades muito maior, ninguém concorda, porém, que a sociedade civilizada seja contra a natureza, e o homem não tenha sido feito para ela, e que ela seja necessariamente infeliz, e muito menos que ela, pela própria essência, seja mais contrária à natureza, e totalmente mais infeliz que a sociedade selvagem ${ }^{564}$.

Semelhante argumentação é do homem civilizado, ou seja, espiritualizado, porém, bem mais de "primitivos e selvagens" [primitivi e selvaggi], ou seja, materiais, pois não destacando senão as calamidades e infelicidades materiais e sensíveis, identificáveis sem raciocínio, ou considerando-as cada vez menores do que aquilo que o raciocínio demonstra o contrário, ou seja, de serem muito maiores e assim negando-se a reconhecer aquelas que na verdade o são, e fazendo-o, porque apenas o raciocínio poderia mostrá-las, identificando infelicidade e crueldade como tais ${ }^{565}$.

Tal argumento, quando assumido também por homens mais civilizados e filósofos, como em geral todos fazem, fornecem, no entender de Leopardi,

no excesso da civilização deles e espiritualização, uma forte confirmação dessa [...] proposição de que não exista algo mais contrário à natureza que a espiritualização do homem e de qualquer coisa, e que

dell'uomo, ch'è essenzial compagna, effetto, sostanza della civiltà. Come le snaturatezze, le calamità, e la infelicità delle società selvagge, per esser naturalmente più fisiche, anzi tutte fisiche e materiali, sono più evidenti e tali che ognuno le può riconoscere per quel che sono, non v'è uomo il quale non convenisse che se la società umana non potesse esser altra che la selvaggia, la società nel gener nostro sarebbe cosa contro natura, e l'uomo non esser fatto per la società, ed in questa esser necessariamente imperfettissimo e infelicissimo".

${ }^{564}$ LEOPARDI, Giacomo. Zibaldone di pensieri, fragmento 3934, 28.11.1823, in: Tutte le poesie, tutte le prose e lo Zibaldone, p. 2235: "quantunque tali danni sieno molto più gravi veramente e contro natura, e tali snaturatezze molto maggiori, niuno però conviene che la società civile sia contro natura, e l'uomo non esser fatto per lei, e ch'ella sia necessariamente infelice, e molto meno ch'ella per propria essenza sia più felice che la società selvaggia".

${ }^{565}$ Cf. LEOPARDI, Giacomo. Zibaldone di pensieri, fragmentos 3934-3935, 28.11.1823, in: Tutte le poesie, tutte le prose e lo Zibaldone, p. 2235. 
tudo [...] por natureza é material, e que a matéria sempre vence, e que, portanto, esses tão civilizados são muito corrompidos, porque no próprio raciocínio deles, com o qual querem defender esse estado deles, e que disso se inspiram, dão a preferência à matéria e não querem raciocinar a não ser materialmente ${ }^{566}$.

O homem é, portanto, "animal dépravé", assim como a sociedade civilizada, por não ser outra coisa senão "espirito" [spirito] ou ser pensante, ou reunião de tais seres. Leopardi justifica com esses argumentos sobre a crueldade e infelicidade verdadeira do homem, valendo-se de observações e provas, como algo que ocorre em proporção com a sua maior civilidade. Daí ser a civilização, por sua natureza, contrária à natureza tanto do homem quanto do universal, ou seja, é causa da grande infelicidade ${ }^{567}$.

\subsection{Ethos antigo e mundo moderno: a crítica poética leopardiana}

Nas suas abordagens iniciais, presentes no Zibaldone, Leopardi reconhece que a perfeição das Belas Artes não é medida pelo o que é mais Belo, mas pela "imitação mais perfeita da natureza"568. Daí a sua indagação: "se é verdade que a perfeição das coisas consiste substancialmente na obtenção do objeto delas, qual será o objeto das Belas Artes?"569. Certamente não é a utilidade a finalidade natural ou ofício delas, mas o "deleitável" [dilettevole] $^{570}$. Não obstante ser mais deleitável uma planta ou animal, visto na realidade do que representado ou imitado, em qualquer gênero de arte, contudo, para Leopardi, "não é possível que na imitação não permaneça nada

${ }^{566}$ LEOPARDI, Giacomo. Zibaldone di pensieri, fragmento 3935, 28.11.1823, in: Tutte le poesie, tutte le prose e lo Zibaldone, p. 2235: "nello stesso eccesso della lor civiltà e spiritualizzazione, una forte conferma di questa [...] proposizione che non vi sia cosa più contraria alla natura che la spiritualizzazione dell'uomo e di qualsivolglia cosa, e che tutto [...] per natura è materiale, e che la materia sempre vince, e che quindi essi così civili e spiritualizzati sono corrottissimi, perchè nello stesso loro ragionamento con cui vogliono difendere questo loro stato, e che loro è inspirato da questo, dànno la preferenza alla materia e non vogliono ragionare che materialmente".

${ }^{567}$ Cf. LEOPARDI, Giacomo. Zibaldone di pensieri, fragmento 3935, 28.11.1823, in: Tutte le poesie, tutte le prose e lo Zibaldone, p. 2235.

568 LEOPARDI, Giacomo. Zibaldone di pensieri, fragmento 3, dezembro,1818, in: Tutte le poesie, tutte le prose e lo Zibaldone, p. 1466: "più perfetta imitazione della natura".

${ }^{569}$ Ibidem: "se è vero che la perfezione dele cose in sostanza consiste nel perfetto conseguimento del loro oggetto, quale sarà l'oggetto delle Belle Arti?".

570 Cf. LEOPARDI, Giacomo. Zibaldone di pensieri, fragmento 3, Dezembro.1818, in: Tutte le poesie, tutte le prose e lo Zibaldone, p. 1466. 
para ser desejado. Mas o contrário expressamente acontece: desde que resulte que a fonte do deleite nas artes não [seja] o belo, mas a imitação" ${ }^{\text {"51 }}$.

$\mathrm{Na}$ sua reflexão sobre o que denomina ressurgimento, Leopardi pressupõe as profundas raízes na obra dos antigos, sobretudo, daquelas que Ihe eram tão apreciadas, ou seja, Homero, Píndaro, Anacreonte, Cícero, Lucrécio, Horácio, Luciano, Xenofonte e Virgílio. Com base nessas fontes ele conduz, igualmente, a sua apreciação do ressurgimento e de seu fazer poético. Em tal apreciação, ele sintetiza na expressão "Gregos, latinos, italianos" [Greci latini italiani], as fontes e o liame que forjará o seu sentido profundo da Antiguidade. Interessa, nesse momento, tal concepção da Antiguidade a fim de se compreender a sua apreciação dos séculos $X V$ e XVI, no tocante à questão formulada no Discorso, de forma muito abreviada, pois o que é relevante em tal exposição é, em especial, aquilo que ainda sobreviveu ou renasceu nesses séculos.

Tendo como base a sua compreensão daquilo que ocorreu à literatura italiana nos séculos anteriores, Leopardi se reporta ao próprio século reconhecendo-o como aquele em que "a arte chegou a um incrível desenvolvimento" [l'arte è venuta in un incredibile accrescimento] ${ }^{572}$, pois, nesse século, "tudo é arte" [tutto è arte] e, aliás,

não existe mais quase nada de espontâneo, a própria espontaneidade se busca com todo poder, mas com um estudo infinito sem o qual não pode ocorrer e sem o qual desde há muito tempo o fizeram (especialmente na língua) Dante, Petrarca, Ariosto [...] e todos os hábeis do século XIV e XVI ${ }^{573}$.

571 Ibidem: "non è possibile che nella imitazione non resti niente a desiderare. Ma il contrario manifestamente avviene: da che apparisce che il fonte del dileto nelle arti non è il bello, ma l'imitazione".

572 Cf. LEOPARDI, Giacomo. Zibaldone di pensieri, fragmento 4, Dezembro.1818, in: Tutte le poesie, tutte le prose e lo Zibaldone, p. 1466.

${ }^{573}$ LEOPARDI, Giacomo. Zibaldone di pensieri, fragmento 4, Dezembro.1818, in: Tutte le poesie, tutte le prose e lo Zibaldone, p. 1466: "non c'è più quasi niente di spontaneo, la stessa spontaneità si cerca a tutto potere ma con uno studio infinito senza il quale non si può avere, e senza il quale a gran pezza l'aveano (spezialmente nella lingua) Dante il Petrarca l'Ariosto [...] e tutti i bravi trecentisti e cinquecentisti'. 
No seu século, isso havia ocorrido, por se tratar de "um tempo corrompido" [un tempo corrotto] ${ }^{574}$, além de se encontrar entre "corruptos" [corrotti]. Semelhante acontecimento ocorre dada à necessidade do estudo, para evitar a corrupção já presente e atuante, mas também aquela dos tempos passados, pois no presente se conhece "todos os vícios das artes e queremos evitar isso" ${ }^{\prime 575}$.

A simplicidade dos gregos e latinos, mas também daqueles pertencentes aos séculos XIV e XVI fora perdida, uma vez que o século de Leopardi havia passado pela corrupção e os poetas se tornado "astutos na arte" [astutti nell'arte $]^{576}$, a forma encontrada para evitar "os vícios com essa astúcia e com a arte, não com a natureza como faziam os antigos, os quais sem saber tanto disso, mesmo porque a arte estava no início e não estava ainda corrompida, não Ihe evitavam, mas aí não caíam"577. A ida aos Antigos justifica-se por causa de um século em que os artistas não conseguem evitar os vícios da arte com a natureza, daí se revelar a astúcia dos modernos.

Leopardi apresenta aqui uma contraposição entre arte e espontaneidade com base naquele entre Antigos e Modernos. Nessa contraposição, os Antigos se apresentam como "crianças que não conheciam os vícios" [fanciulli che non conoscono $i \mathrm{vizi}$ e os modernos "como velhos que os conheciam, mas pelo bom-senso e as experiências lhes evitavam" ${ }^{578}$. Como crianças e jovens, os Antigos, apesar da boa índole e da malícia natural, escapavam, segundo Leopardi, de vez em quando, de algum defeito e não por serem tão diferentes

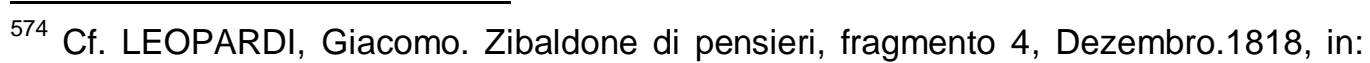
Tutte le poesie, tutte le prose e lo Zibaldone, p. 1466.

${ }^{575}$ LEOPARDI, Giacomo. Zibaldone di pensieri, fragmento 4, Dezembro.1818, in: Tutte le poesie, tutte le prose e lo Zibaldone, p. 1466: "tutti i vizi delle arti e ce ne vogliamo guardare".

${ }^{576}$ Cf. LEOPARDI, Giacomo. Zibaldone di pensieri, fragmento 4, Dezembro.1818, in: Tutte le poesie, tutte le prose e lo Zibaldone, p. 1466.

577 LEOPARDI, Giacomo. Zibaldone di pensieri, fragmento 4, Dezembro.1818, in: Tutte le poesie, tutte le prose e lo Zibaldone, p. 1466: "i vizi con questa astuzia e coll'arte non colla natura come facceano gli antichi i quali senza saperne più che tanto pure perchè l'arte era in sul principio e non ancora corrotta non gli schivavano ma no ci cadevano".

${ }^{578}$ LEOPARDI, Giacomo. Zibaldone di pensieri, fragmento 4, Dezembro.1818, in: Tutte le poesie, tutte le prose e lo Zibaldone, p. 1466: "come vecchi che li conosciamo ma pel senno e l'esperienza gli schiviamo". 
dos "homens grandes e maus" [uomini grandi e cattivi] ${ }^{579}$. Para Leopardi, os Antigos,

\begin{abstract}
sem conhecerem nem amarem os vícios das artes, pela tendência natural do engenho ao requinte e a tais coisas, de vez em quando aí caíam, não refletindo que fossem vícios, e não diferiam tão infinitamente dos artifícios adultos do século XVII e XVIII radicados na corrupção ${ }^{580}$.
\end{abstract}

Leopardi sintetiza em sua crítica-poética aos Modernos, na qual justifica o estudo dos Clássicos, certa atitude a fim de se evitar os vícios da arte e de sua artificialidade. Conforme escreve no Zibaldone di pensieri:

Para nos proteger dos vícios e da corrupção do escrever, é preciso agora um estudo infinito e uma grandíssima imitação dos clássicos, bem maior daquela que os antigos não precisavam, sem as quais coisas não se pode ser célebre escritor, e com as quais não se pode se tornar grande como os grandes imitados ${ }^{581}$.

Atento à situação dos modernos, ou seja, de corrupção e vícios, revelados pela perda da espontaneidade e pela presença de tanta astúcia e arte, Leopardi ressalta nos Antigos o modo como enfrentavam o perigo de falharem em uma obra. Eles não pensavam nele e se conduziam com franqueza: algo que justificava assim a realização da atividade poética com êxito. Desse modo, de acordo com Leopardi,

os poetas antigos não apenas não pensavam no perigo no qual haveriam de [...] errar, mas [...] sabiam apenas que existisse e, porém, de modo muito sincero se dirigiam com aquela belíssima negligência que acusa a obra da natureza e não do esforço ${ }^{582}$.

${ }^{579}$ Cf. LEOPARDI, Giacomo. Zibaldone di pensieri, fragmento 5, Dezembro.1818, in: Tutte le poesie, tutte le prose e lo Zibaldone, p. 1466.

${ }^{580}$ LEOPARDI, Giacomo. Zibaldone di pensieri, fragmento 5, Dezembro.1818, in: Tutte le poesie, tutte le prose e lo Zibaldone, p. 1466: "senza conoscere nè amare i vizi delle arti, per la naturale tendenza dell'ingegno alla ricercatezza e cose tali di quando in quando vi cadeano non riflettendo che fossero vizi, e non per tanto infinitamente differivano dagli adulti artefici del 600 e 700 radicati nella corruzione".

581 LEOPARDI, Giacomo. Zibaldone di pensieri, fragmento 5, Dezembro.1818, in: Tutte le poesie, tutte le prose e lo Zibaldone, p. 1467: "Per guardarci dai vizi e dalla corruzione dello scrivere adesso è necessario un infinito studio e una grandissima imitazione dei Classici, molto molto maggiore di quella che agli antichi non bisognava, senza le quali cose non si può essere insigne scrittore, e colle quali cose non si può diventar grande come i grande imitati".

582 LEOPARDI, Giacomo. Zibaldone di pensieri, fragmentos 9-10, Dezembro.1818, in: Tutte le poesie, tutte le prose e lo Zibaldone, p. 1468: "i poeti antichi non solamente non 
Nos modernos ocorre algo diferente, pois muito tímidos e sabendo de poder errar com o pensamento sempre no perigo de quem errou e continua errando, justamente por causa de ver a corrupção do século, conduziria mais facilmente aos grandes erros ${ }^{583}$. Há nos modernos uma preocupação exacerbada com regras e modelos, pois daquilo que não ousam se distanciar, não é dos exemplos, escreve Leopardi,

dos antigos e dos Clássicos que muito até sabem abandonar, mas daquelas regras (ótimas e clássicas, mas sempre regras) que formamos na mente, e damos voos baixos, nem jamais ousamos elevar-nos com aquela negligente e segura, não atenta [...] ignorante franqueza [...] necessária nas sumas obras da arte ${ }^{584}$.

Por causa então do temor de realizarem péssimas obras, os modernos realizam, ao contrário, obras medíocres e de certa mediocridade, ou seja, no dizer de Horácio, escreve Leopardi, insuportável, a saber, bem trabalhadas, estudadas, muito polidas ${ }^{585}$. Trata-se, portanto, da ausência de espontaneidade, de negligência, de franqueza e audácia. Aqui se apresenta a distinção fundamental entre a obra dos Antigos e aquela dos Modernos, cuja distinção orienta igualmente a interpretação leopardiana do ethos antigo e de sua compreensão poética e antropológica. Também orienta, em certo modo, do fazer poético, ou seja, de certas características das civilizações confrontadas nessas suas observações e de uma postura ante a poesia romântica do seu tempo. Por conseguinte, a obra antiga tornou-se algo inatingível na Idade moderna.

pensavano al pericolo in cui erano di [...] errare, ma (especialmente Omero) appena sapevano che ci fosse, e però franchissimamente si diportavano, con quella belissima negligenza che accusa l'opera della natura e non della fatica".

${ }^{583}$ Cf. LEOPARDI, Giacomo. Zibaldone di pensieri, fragmento 10, Dezembro.1818, in: Tutte le poesie, tutte le prose e lo Zibaldone, p. 1468.

${ }^{584}$ LEOPARDI, Giacomo. Zibaldone di pensieri, fragmento 10, Dezembro.1818, in: Tutte le poesie, tutte le prose e lo Zibaldone, p. 1468: "degli antichi e dei Classici, che molti pur sapranno abbandonare, ma da quelle regole (ottime e Classiche ma sempre regole) che ci siamo formate in mente, e diamo in voli bassi, nè mai osiamo di alzarci con quella negligente $e$ sicura e non curante e dirò pure ignorante franchezza, [...] necessaria nelle somme opere dell'arte".

${ }^{585}$ Cf. LEOPARDI, Giacomo. Zibaldone di pensieri, fragmento 10, Dezembro.1818, in: Tutte le poesie, tutte le prose e lo Zibaldone, p. 1468. 
A abordagem leopardiana da poesia dos antigos pressupõe certa compreensão também do progresso da civilização com o avançar da razão, provocando igualmente uma diminuição da natureza e da fantasia. A poesia sofrera também os danos oriundos da perda daquilo que dominava o ethos antigo, ou seja, as ilusões. Daí a "grande verdade" [gran verità], não obstante a necessidade de ponderá-la bem, de que a razão "é inimiga de toda grandeza: a razão é inimiga da natureza: a natureza é grande, a razão é pequena" ${ }^{586}$. 0 homem dificilmente será grande, escreve Leopardi, enquanto dominado pela razão, poucos puderam ser grandes, em especial, nas artes e na poesia talvez nenhum, pois é preciso o domínio das ilusões ${ }^{587}$.

O "século da razão" [secolo della ragione] não comporta os grandes feitos, o extraordinário, fora de toda ordem e presente certa desordem condenada pela razão. Por isso são poucos os "grandes homens" [grandi uomini], sobretudo, nas artes, pois são aqueles dominados pelas ilusões. Ao contrário dos modernos, os poetas antigos pintavam simplesmente a natureza, aqueles objetos e circunstâncias que despertavam esses sentimentos e os sabiam "pintar e imitar" [dipingere e imitare] a ponto de se poder ver nos versos deles, o quanto isso possa ser possível, esses objetos mesmos como se estivessem na natureza. Isso porque

na natureza nos despertam esses sentimentos, também pintados e imitados com tanta perfeição nos despertam igualmente, tanto mais que 0 poeta escolheu os objetos, pôs-Ihes na verdadeira luz e com a sua arte nos preparou para receber deles aquela impressão de que está na natureza ${ }^{588}$.

Portanto, os poetas imitavam a natureza, a "natureza nua" [nuda natura], preparando-a para os leitores, mas "eles mesmos ou não a

586 LEOPARDI, Giacomo. Zibaldone di pensieri, fragmento 14, Dezembro.1818, in: Tutte le poesie, tutte le prose e lo Zibaldone, p. 1470: "è nemica d'ogni grandezza; la ragione è nemica della natura: la natura è grande, la ragione è piccola".

${ }^{587}$ Cf. LEOPARDI, Giacomo. Zibaldone di pensieri, fragmento 14, Dezembro.1818, in: Tutte le poesie, tutte le prose e lo Zibaldone, p. 1470.

588 LEOPARDI, Giacomo. Zibaldone di pensieri, fragmento 16, Dezembro.1818, in: Tutte le poesie, tutte le prose e lo Zibaldone, p. 1471: "in natura ci destano quei sentimenti, anche dipinti e imitati con tanta perfezione ce li destano egualmente, tanto più che il poeta ha scelti gli oggetti, gli ha posti nel loro vero lume, e coll'arte sua ci ha preparati a ricerverne quell'impressione, dovechè in natura". 
experimentavam, ou não diziam experimentá-la, de forma muito simples, como pastorinhos descreviam aquilo que viam e não acrescentavam nada deles"589. Reenviando a Aristóteles, Leopardi justifica esse fazer poético dos antigos, de que o poeta "quanto mais fala em pessoa e quanto mais acrescenta de seu, tanto menos imita" ${ }^{590}$. Já os poetas modernos seguem, portanto, o

grande ideal dos nossos tempos, esse conhecer tão intimamente 0 nosso coração, esse analisar, prognosticar, distinguir dele, um por um, todos os menores afetos, essa arte, enfim psicológica, destrói a ilusão sem a qual não existirá poesia perpétua, destrói a grandeza do ânimo e das ações ${ }^{591}$.

Leopardi reconhece a superioridade dos antigos em relação aos modernos no fato que gozavam daquela "infância na qual tudo é singular e maravilhoso, em que a imaginação parece que não tenha limites" ${ }^{592}$, pois identifica a capacidade do homem de ser seduzido, de "palpitar por uma coisa que conhece vã"593. A falta justamente dessa capacidade significa, para Leopardi, a falta de ilusão, sem a qual não existe poesia, ou ainda, a poesia se torna algo do raciocínio como se precisasse ser "raciocinada e na proporção com as luzes da nossa idade" ${ }^{\prime 594}$. Isso, segundo Leopardi, os românticos afirmam.

Tal coisa ocorre é porque as ilusões desapareceram e "se o poeta não pode iludir não é mais poeta, e uma poesia refletida é o mesmo que dizer um

589 Ibidem: "essi stessi o on la provavano, o non dicevano di provarla; semplicissimamente, come pastorelli, descrivevano quel che vedevano, e non ci aggiugnevano niente del loro".

590 Ibidem: "il poeta quanto più parla in persona propria e quanto più aggiunge di suo, tanto meno imita".

591 LEOPARDI, Giacomo. Zibaldone di pensieri, fragmento 17, Dezembro.1818, in: Tutte le poesie, tutte le prose e lo Zibaldone, p. 1471: "grand'ideale dei tempi nostri, questo conoscere così intimamente il cuor nostro, questo analizzarne, prevederne, distinguere ad uno ad uno tutti i più minuti affetti, quest'arte insomma psicologica, distrugge l'illusione senza cui non ci sarà poesia in sempiterno, distrugge la grandezza dall'animo e delle azioni".

592 Ibidem: "puerizia, in cui tutto è singolare e maraviglioso, in cui l'immaginazione par che non abbia confine".

593 LEOPARDI, Giacomo. Zibaldone di pensieri, fragmento 17, Dezembro.1818, in: Tutte le poesie, tutte le prose e lo Zibaldone, p. 1472: "palpitare per una cosa che conosce vana".

594 LEOPARDI, Giacomo. Zibaldone di pensieri, fragmento 18, Dezembro.1818, in: Tutte le poesie, tutte le prose e lo Zibaldone, p. 1472: "ragionevole, e in proporzione coi lume dell'età nostra". 
animal racional" ${ }^{295}$. Por conseguinte, os antigos realizaram o máximo da arte, porque "imunes dos preconceitos da arte" [immuni dai pregiudizi dell'arte] ${ }^{596}$, onde predominava ainda a simplicidade e a naturalidade e não o artifício e a afetação, permanecia ainda a ilusão.

A reflexão leopardiana sobre o poético se realiza em consonância com o ethos e as circunstâncias históricas. Por conseguinte não se trata de uma reflexão da arte como tal, mas em conformidade com a compreensão daquilo que foi também em sentido antropológico e cultural o mundo antigo e as mudanças ocorridas no mundo moderno. Segundo Leopardi, "a razão fazendo naturalmente amigos justamente do útil como tal, e tirando as ilusões que nos unem uns aos outros, dissolve absolutamente a sociedade, e torna feroz as pessoas" ${ }^{\prime 297}$. Por isso, os antigos poetas foram mais originais do que os modernos.

Leopardi se reporta a Francis Bacon para considerar as faculdades no universo da arte, sustentando com Bacon que "todas as faculdades reduzidas à arte se tornam estéreis" ${ }^{598}$, ou seja, "os homens não encontram outra coisa que as amplifique, como encontravam quando eram ainda informes e sem nome e sem leis próprias" ${ }^{\prime 599}$. Ele compreende que a poesia do seu tempo tenha se reduzido à arte, mas para ser

realmente original é preciso romper, violar, desprezar, deixar de lado inteiramente os costumes, os usos e as noções de gêneros [...] recebidas de todos, coisa difícil de se fazer e da qual se priva também o sábio, porque usos são respeitados em um grau máximo nas coisas

\footnotetext{
${ }^{595}$ Ibidem: "se il poeta non può illudere non è più poeta, e una poesia ragionevole, è lo stesso che dire una bestia ragionevole".

${ }^{596}$ Cf. LEOPARDI, Giacomo. Zibaldone di pensieri, fragmento 20, Dezembro.1818, in: Tutte le poesie, tutte le prose e lo Zibaldone, p. 1473.

597 LEOPARDI, Giacomo. Zibaldone di pensieri, fragmento 23, Dezembro.1818, in: Tutte le poesie, tutte le prose e lo Zibaldone, p. 1475: "la ragione facendo naturalmente amici dell'utile proprio, e togliendo le illusioni che ci legano gli uni agli altri, scioglie assolutamente la società, e inferocisce le persone".

${ }^{598}$ LEOPARDI, Giacomo. Zibaldone di pensieri, fragmento 39, 08.01.1820, in: Tutte le poesie, tutte le prose e lo Zibaldone, p. 1483: "tutte le facoltà ridotte ad arte steriliscono".

599 Ibidem: "gli uomini non trovano altro che le amplifichi, come trovavano quando ell'erano ancora informi e senza nome e senza leggi proprie".
} 
feitas pelo povo como são as poesias, nem é enganado o público com nomes falsos ${ }^{600}$.

$\mathrm{Na}$ Modernidade torna-se difícil para o poeta assumir essa orientação, pois, como Leopardi argumenta,

com tantos usos, com tantos exemplos, com tantas nações, definições, regras, formas, com tantas leituras [...], por mais que um poeta queira se distanciar da estrada indicada a cada instante aí retorna, enquanto a natureza não opera mais por si sempre, naturalmente e necessariamente influem sobre a mente do poeta as ideias adquiridas que circunscrevem a eficácia da natureza e diminuem a faculdade inventiva ${ }^{601}$.

Trata-se, para Leopardi, da faculdade inventiva de um verdadeiro poeta, que saberia encontrar coisas sempre novas e não tocadas por outros ${ }^{602}$.

Aqui se apresenta o modo particular de Leopardi impostar a sua reflexão sobre a essência da poesia, em especial aquela lírica, ou seja, a mais elevada da arte poética, pois nela se encontram alguns elementos encontrados na poesia antiga: a naturalidade, a espontaneidade e a simplicidade. Tais elementos pertencem tanto à locução quanto aos sentimentos. Daí a comparação da poesia dos antigos com a imaginação das crianças ${ }^{603}$. A sua experiência no presente moderno, com tamanha espiritualização das coisas e dos homens, de tempos de fragilidade poética, faz que se reporte a certa época e ethos. Nesse sentido ele escreve:

Que belo tempo era aquele no qual toda coisa era viva segundo a imaginação humana e viva humanamente, isto é, habitada ou formada por seres [...] iguais a nós,

${ }^{600}$ LEOPARDI, Giacomo. Zibaldone di pensieri, fragmento 39, 08.01.1820, in: Tutte le poesie, tutte le prose e lo Zibaldone, pp. 1483-1484: "veramente originale bisogna rompere violare disprezzare lasciare da parte intieramente i costumi e le abitudini e le nozioni di nomi di generi [...] ricevute da tutti, cosa difficile a fare, e dalla quale si astiene ragionevolmente anche il savio, perchè le consuetudini vanno rispettate massimamente nelle cose fatte pel popolo come sono le poesie, nè va ingannato il pubblico con nomi falsi".

${ }^{601}$ LEOPARDI, Giacomo. Zibaldone di pensieri, fragmento 40, 08.01.1820, in: Tutte le poesie, tutte le prose e lo Zibaldone, p. 1484: "con tanti usi con tanti esempi, con tante nozioni, definizioni, regole, forme, con tante letture [...] per quanto un poeta si voglia allontanare dalla strada segnata a ogni poco ci ritorna, mentre la natura non opera più da se, sempre naturalmente e necessariamente influiscono sulla mente del poeta le idee acquistate che circoscrivono l'efficacia della natura e scemano la facoltà inventiva".

${ }^{602}$ Cf. LEOPARDI, Giacomo. Zibaldone di pensieri, fragmento 40, 08.01.1820, in: Tutte le poesie, tutte le prose e lo Zibaldone, p. 1484.

603 Singh, 131. 
quando nos bosques muito desertos se julgava certamente que habitassem as belas hamadríades e os faunos, os silvanos e Pã ${ }^{604}$.

A imaginação, como faculdade antropológica fundamental da vida humana e de suas criações, revela-se também como requisito fundamental da poesia. Por isso, a imaginação, na sua justaposição com a razão constitui, no entender de Leopardi, a qualidade com base na qual a poesia dos antigos foi superior à moderna. Isso porque a imaginação é mãe e nutriz das ilusões, ao passo que a razão lhe é inimiga. Daí Leopardi exclamar: "Oh infinita inutilidade do verdadeiro!" [Oh infinita vanità del vero] ${ }^{605}$.

Também a dor dos antigos apresentava grande diferença em relação àquela moderna, pois a dor dos antigos era "desesperad[a], como costuma ser por natureza [...] sem o conforto da sensibilidade, sem a doce resignação para desventuras conhecidas por nós, não por eles, inevitáveis" ${ }^{\prime 606}$. Ela não estava "misturada com nenhuma amarga e doce ternura de si mesmo"607.

Isso conferia à tragédia dos antigos um sentido de fatalidade e estoicismo, eliminado do homem moderno pelo Cristianismo, mas eliminadas também aquela nobreza e dignidade, ou seja, a mesma coisa com a naturalidade e simplicidade ${ }^{608}$. Nos modernos, essas qualidades foram substituídas pela sutileza e afetação.

Leopardi reconhece, como se apresentou também no Discorso de 1824 , que "as diversas circunstâncias desenvolvem as diversas faculdades naturais da alma, que permanecem escondidas e inoperantes, se faltam aquelas tais circunstâncias físicas, políticas, morais e, sobretudo, no nosso caso,

$\overline{604}$ LEOPARDI, Giacomo. Zibaldone di pensieri, fragmentos 63-64, 08.01.1820, in: Tutte le poesie, tutte le prose e lo Zibaldone, p. 1495: "Che bel tempo era quello nel quale ogni cosa era viva secondo l'immaginazione umana e viva umanamente cioè abitata o formata di esseri [...] uguali a noi, quando nei boschi desertissimi si giudicava per certo che abitassero le belle Amadriadi e i fauni e i silvani e Pane".

${ }^{605}$ Cf. LEOPARDI, Giacomo. Zibaldone di pensieri, fragmento 69, 08.01.1820, in: Tutte le poesie, tutte le prose e lo Zibaldone, p. 1496.

${ }^{606}$ LEOPARDI, Giacomo. Zibaldone di pensieri, fragmento 77, 08.01.1820, in: Tutte le poesie, tutte le prose e lo Zibaldone, p. 1499: "disperato, come suol essere in natura [...] senza il conforto della sensibilità, senza la rassegnazion dolce alle sventure da noi, non da loro, conosciute inevitabili".

${ }^{607}$ Ibidem: "mescolato di nessuna amara e dolce tenerezza di se stesso".
${ }^{608}$ Cf. Singher 
intelectuais"609. O desenvolvimento das faculdades intelectuais, no seu entender, explica o aparecimento no homem do "sentimento e da melancolia" [sentimento e della melancolia] ${ }^{610}$, decorrentes, sobretudo,

do progresso da Filosofia, do conhecimento do homem, do mundo, da vacuidade das coisas e da infelicidade humana, [...] conhecimento que produz precisamente essa infelicidade, que na natureza não devia jamais conhecer $^{611}$.

No ethos antigo, a felicidade, graças à potência da imaginação dos homens antigos, "não parecia um sonho" [non pareva un sogno] ${ }^{612}$. Da mesma forma ante a dor se apresentava certa distinção real entre o elemento sentimental e o ilusório. Daí Leopardi dizer, como nos antigos poetas, sobretudo nos gregos, "costumavam deixar o que pensar para o expectador ou ouvinte, mais do que aquilo que exprimiam"613. Por isso eles conseguiam "simplicidade e naturalidade" [semplicità e naturalità]:

pela qual não iam como os modernos atrás de minúcias da coisa, demonstrando, de forma evidente, o estudo do escritor, que não fala ou descreve a coisa como a natureza mesma a apresenta, mas vai subtilizando, observando as circunstâncias, esmiuçando e alongando a descrição pelo desejo de causar efeito, algo que descobre o propósito, destrói a desenvoltura e negligência natural, e manifesta a arte e a afetação, e introduz na poesia o falar mais o poeta que a coisa ${ }^{614}$.

${ }^{609}$ LEOPARDI, Giacomo. Zibaldone di pensieri, fragmento 78, 08.01.1820, in: Tutte le poesie, tutte le prose e lo Zibaldone, p. 1499: "le diverse circostanze sviluppano le diverse facoltà naturali dell'anima, che restano nascose e inoperose mancando quelle tali circostanze, fisiche, politiche, morali, e sopratutto, nel nostro caso, intellettuali".

${ }^{610}$ Cf. LEOPARDI, Giacomo. Zibaldone di pensieri, fragmento 78, 08.01.1820, in: Tutte le poesie, tutte le prose e lo Zibaldone, p. 1499.

${ }^{611}$ LEOPARDI, Giacomo. Zibaldone di pensieri, fragmentos 78-79, 08.01.1820, in: Tutte le poesie, tutte le prose e lo Zibaldone, p. 1499: "dal progresso della filosofia, e della cognizione dell'uomo, e del mondo, e della vanità delle cose, e della infelicità umana, [...] cognizione che produce appunto questa infelicità, che in natura non dovevamo mai conoscere".

${ }^{612}$ Cf. LEOPARDI, Giacomo. Zibaldone di pensieri, fragmento 77, 08.01.1820, in: Tutte le poesie, tutte le prose e lo Zibaldone, p. 1498.

${ }^{613}$ LEOPARDI, Giacomo. Zibaldone di pensieri, fragmento 100, 08.01.1820, in: Tutte le poesie, tutte le prose e lo Zibaldone, p. 1505: "solevano lasciar da pensare allo spettarore 0 uditore più di quello ch'esprimessero".

614 Ibidem: "per cui non andavano come i moderni dietro alle minuzie della cosa, dimostrando evidentemente lo studio dello scrittore, che non parla o descrive la cosa come la natura stessa la presenta, ma va sottilizzando, notando le circostanze, sminuzzando e allungando la descrizione per desiderio di fare effetto, cosa che scuopre il proposito, distrugge 
Por conseguinte, os antigos não pensaram, como os modernos, nesse efeito e tornavam a expressão de sua poesia e arte infinita, "lá onde aquela dos modernos é finita, pois, descrevendo com poucos toques e mostrando poucas partes do objeto, "deixavam a imaginação vaguear no indefinido daquelas ideias infantis, que nascem da ignorância do todo" ${ }^{115}$. Nos antigos, as ilusões e em "cada sentimento doce e sublime" [ogni sentimento dolce e sublime] participa sempre e "é a mais acerba dor, ver se suprimir e desvelar"616 - eram, portanto, diferentes daquelas modernas, diferentes porque operavam mediante o engano da razão, e não, como nos modernos, com o engano da fantasia. Por isso nos antigos, o engano é mais conveniente à poesia e nos modernos à Filosofia.

É por meio do engano da razão que se atinge as grandes paixões e as grandes ilusões, pois são incompatíveis com a "certeza" [certeza] e com o "sentimento vivo da nulidade de todas as coisas, e da impossibilidade de ser feliz nesse mundo, e da imensidade do vazio do que se sente na alma"617. Para Leopardi, a imaginação dos antigos era mais forte que a dos modernos. Ele distingue também a força da fecundidade da imaginação: aquela de Homero e Dante era mais forte, a de Ovídio e Ariosto fecunda. Isso decorria, em parte, do engano da razão deles, por meio da qual a natureza quis que a imaginação oferecesse sobre eles ${ }^{618}$.

la naturale disinvoltura e negligenza, manifesta l'arte e l'affettazione, ed introduce nella poesia a parlare più il poeta che la cosa".

${ }^{615}$ Ibidem: "laddove quella de' moderni è finita. Perchè descrivendo con pochi colpi, e mostrando poche parti dell'oggetto, lasciavano l'immaginazione errare nel vago e indeterminado di quelle idee fanciullesche, che nascono dall'ignoranza dell'intiero".

${ }^{616}$ LEOPARDI. Giacomo. Zibaldone di pensieri, fragmento 101, 08.01.1820, in: Tutte le poesie, tutte le prose e lo Zibaldone, p. 1505: "è il più acerbo dolore il vedersi togliere e svelare".

${ }^{617}$ LEOPARDI. Giacomo. Zibaldone di pensieri, fragmento 140, 27.06.1820, in: Tutte le poesie, tutte le prose e lo Zibaldone, p. 1516: "sentimento vivo della nullità di tutte le cose, e della impossibilità di esser felice a questo mondo, e dalla immensità del vuoto che si sente nell'anima".

618 Cf. SINGH, Ghan. Leopardi filosofo anti-filosofo, Pisa-Roma: Istituti Editoriali e Poligrafi Internazionali, 1997, p. 132. 
Esse engano pressupõe aquilo que Leopardi denomina de "certa ignorância [...] dos antigos" ${ }^{\prime 19}$, pois quanto mais reinar essa ignorância, tanto mais o homem será feliz. Sobre esse argumento, Leopardi escreve:

a natureza quis que a imaginação não fosse considerada pelo homem como tal, ou seja, não quis que 0 homem a considerasse como faculdade enganadora, mas a confundisse com a faculdade de conhecimento, e por isso tomasse os sonhos da imaginação como coisas reais e, portanto, fosse encorajado pela imaginação como pelo verdadeiro (aliás, mais, porque 0 imaginário tem forças mais naturais, e a natureza é superior à razão). Mas agora as pessoas instruídas, quando também sejam muito fecundas de ilusão, as tomam como tais, e as seguem mais por vontade que por persuasão, ao contrário dos antigos $^{620}$.

O conhecimento do verdadeiro, ou seja, "dos limites e definições das coisas" [dei limiti e definizioni dele cose] ${ }^{621}$, delimita, no entanto, a imaginação. Não obstante se apresentar, com frequência, maior nos instruídos que nos ignorantes, "não o é em ato como em potência, e por isso operando muito mais nos ignorantes, os faz mais felizes que aqueles" ${ }^{\text {" } 22}$.

É com base no ethos e nas condições e situações históricas, morais e culturais, sem descurar um exame intenso dos textos dos autores, que Leopardi constrói as suas premissas para a compreensão daquilo que caracteriza e distingue o modo de ser antigo daquele moderno. Ele destaca 0

${ }^{619}$ LEOPARDI, Giacomo. Zibaldone di pensieri, fragmento 168, 12-23.07.1820, in: Tutte le poesie, tutte le prose e lo Zibaldone, p. 1524: " una certa ignoranza [...] degli antichi”.

620 Ibidem: "la natura ha voluto che l'immaginazione non fosse considerata dall'uomo come tale, cioè non ha voluto che l'uomo la considerasse come facoltà ingannatrice, ma la confondesse colla facoltà conoscitrice, e perciò avesse i sogni dell'immaginazione per cose reali e quindi fosse animato dall'immaginario come dal vero (anzi più, perchè l'immaginario ha forze più naturali, e la natura è sempre superiore alla ragione). Ma ora le persone istruite, quando anche sieno fecondissime d'illusioni le hanno per tali, e le seguono più per volontà che per persuasione, al contrario degli antichi".

${ }^{621}$ Cf. LEOPARDI, Giacomo. Zibaldone di pensieri, fragmento 168, 12-23.07.1820, in: Tutte le poesie, tutte le prose e lo Zibaldone, p. 1524.

622 LEOPARDI, Giacomo. Zibaldone di pensieri, fragmento 168, 12-23.07.1820, in: Tutte le poesie, tutte le prose e lo Zibaldone, p. 1524: "non lo è in atto come in potenza, e perciò operando molto più negl'ignoranti, li fa più felice di quelli". 
"vigor do corpo, da jovialidade, da coragem, de todos os dotes corporais" ${ }^{623}$ nos antigos. Também o entusiasmo pela glória e pela pátria, ou seja, "todos os dotes venturosos de uma civilização que está no seu verdadeiro ponto entre a natureza e a razão" ${ }^{\prime 24}$. Ademais se constitui ainda como característica dos antigos, "uma melancolia gerada pelas desgraças particulares, e não da desesperada filosofia, porém, mais propriamente e geralmente do clima" ${ }^{25}$.

Disso resulta uma diferença fundamental entre o modo pelo qual o gênio e a grandeza dos antigos se desenvolveu, quando comparado ao modo dos modernos $^{626}$. Nesse sentido se destaca a abordagem leopardiana sobre a grandeza do engenho entre antigos e modernos. Para Leopardi,

a grandeza pertencente ao engenho não se pode obter hoje sem uma ação contínua destruidora da alma sobre o corpo, da lâmina sobre a bainha. Não antigamente assim onde o gênio e a grandeza era mais natural e espontânea, e com menos obstáculos para se desenvolver, além da menor força, do conhecimento destruidor do verdadeiro inseparável hoje em dia dos grandes talentos, e o maior exercício do corpo considerado coisa nobre e necessária, e como tal usado também pelas pessoas de grande gênio ${ }^{627}$.

O homem político tal como o homem de Letras está sempre ocupado na Modernidade - em atividades muito insalubres de gabinete, algo contrário à atividade política dos antigos. Nas "antigas repúblicas quem aspirasse aos negócios civis, e na sua jovialidade, fortificava necessariamente o corpo com

${ }^{623}$ LEOPARDI, Giacomo. Zibaldone di pensieri, fragmento 205, 11.08.1820, in: Tutte le poesie, tutte le prose e lo Zibaldone, p. 1534: "del vigor del corpo, della giovanezza, del coraggio, di tutte le doti corporali".

${ }^{624}$ Ibidem: "tutti i beati distintivi di una civilizazzione che sta nel suo vero punto fra la natura e la ragione".

625 Ibidem: "una maliconia generate dale disgrazie particolari, e non dalla disperante filosofia, ma più propriamente e generalmente dal clima".

${ }^{626}$ Cf. SINGH, Ghan. Leopardi filosofo anti-filosofo, p. 133.

${ }^{627}$ LEOPARDI, Giacomo. Zibaldone di pensieri, fragmento 207, 11.08.1820, in: Tutte le poesie, tutte le prose e lo Zibaldone, p. 1535: "la grandezza appartenente all'ingegno non si può ottenere oggidì senza una continua azione logoratrice dell'anima sopra il corpo, della lama sopra il fodero. Non così anticamente, dove il genio e la grandezza era più naturale e spontanea, e con meno ostacoli a svilupparsi, oltre la minor forza della distruttrice cognizione del vero inseparabile oggidì dai grandi talenti, e il maggior esercizio del corpo riputato cosa nobile e necessaria, e come tale usato anche dalle persone di gran genio". 
os exercícios [...], sem os quais teria sido quase vil"628. Assim como o exercício da política, pleno de ação corporal entre os antigos, do mesmo modo ocorria na "vida de qualquer homem de gênio era sempre cheia de ação no exercício mesmo das suas faculdades" $" 29$.

Quando Leopardi indaga as razões pelas quais "a poesia de hoje em dia não pode produzir aqueles grandes efeitos, nem com relação ao espanto e deleite, nem com relação à excitação dos ânimos, das paixões [...] ao impulso e a grandes ações" ${ }^{630}$. Trata-se de sua interpretação da transição do antigo ao moderno como fragilização crescente das ilusões, ou seja, da perda igualmente de sua capacidade de persuadir, ao passo que no antigo ethos elas iludiam sem se aperceber ${ }^{631}$. Na Modernidade é difícil não se considerar e não se conhecer as ilusões como tais.

É, portanto, com base na faculdade persuasiva das ilusões, não consideradas tais, que brota, conforme Leopardi, aquela força viva e motora, identificada nem com a razão nem com a paixão, mas com a capacidade de se converter a razão em paixão ${ }^{632}$. Leopardi escreve:

A natureza dos homens e das coisas, pode bem ser corrompida, mas não corrigida. E se deixássemos operar a natureza, as coisas iriam muito bem, não obstante a dita superioridade da paixão sobre a razão. Não é preciso extinguir a paixão com a razão, mas converter a razão em paixão; fazer que o dever, a virtude, o heroísmo [...] se tornem paixões. Tais são por natureza. Tais eram junto aos antigos e as coisas iam muito melhor ${ }^{633}$.

${ }_{628}$ Ibidem: "antiche repubbliche chi aspirava agli affari civili, e nella sua giovanezza fortificava necessariamente il corpo cogli esercizi [...] senza i quali sarebbe stato quasi infame".

${ }^{629}$ LEOPARDI, Giacomo. Zibaldone di pensieri, fragmento 207, 11.08.1820, in: Tutte le poesie, tutte le prose e lo Zibaldone, p. 1535: "vita di qualunque altro uomo di genio era sempre piena di azione nell'esercizio stesso delle sue facoltà".

${ }^{630}$ LEOPARDI, Giacomo. Zibaldone di pensieri, fragmento 287, 19.08.1820, in: Tutte le poesie, tutte le prose e lo Zibaldone, p. 1553: "la poesia oggidì non può produrre quei grandi effetti nè riguardo alla maraviglia e al diletto, nè riguardo all'eccitamento degli animi, delle passioni [...] all'impulso a grandi azioni".

\footnotetext{
${ }^{631}$ Ver aqui SINGH, Ghan. Leopardi filosofo anti-filosofo, p. 133.

${ }^{632}$ Cf. SINGH, Ghan. Leopardi filosofo anti-filosofo, p.134.

${ }^{633}$ Cf. SINGH, Ghan. Leopardi filosofo anti-filosofo, p. 293-294.
} 
Entre os antigos, Leopardi comenta que Teofrasto, mesmo sendo filósofo e Mestre de escola,

conhecendo as ilusões, não fugia, porém [...] delas ou as expulsava como os nossos filósofos loucos, mas as buscava e as amava, aliás se fazia condenar pelos outros antigos filósofos, justamente porque venerava as ilusões muito mais do que eles ${ }^{634}$.

Quanto às ilusões dos modernos, tão diferentes daquela dos antigos, Leopardi considera a Religião como a mais fértil e mais poderosa. Ele se opõe aos "apologistas da Religião" [apologisti della Religione] ${ }^{635}$, defensores de que "o mundo estava em um estado de morte na época do primeiro aparecimento do Cristianismo; que esse o reanimou"636, e de que ocorrera por causa da onipotência divina, a qual provava a sua verdade, salvando assim o mundo. Para refutar esse argumento, Leopardi sustenta:

Aquilo que matava o mundo era a falta das ilusões; o Cristianismo o salvou não como verdade, mas como uma nova ilusão. $\mathrm{E}$ os efeitos que ele produziu, entusiasmo, fanatismo, sacrifícios magnânimos, heroísmo, são as frequentes consequências de uma grande ilusão $^{637}$.

Para Leopardi é na qualidade e eficácia das ilusões, como ocorre nos antigos, e também na postura deles ante as mesmas, enquanto os modernos como descobridores e conhecedores do rigoroso verdadeiro "não se consolavam nunca com o pensamento porque esse fosse ilusão, conhecendo que nisso consiste a vida, ou considerando-as como tais ou como

$\overline{634}$ LEOPARDI, Giacomo. Zibaldone di pensieri, fragmentos 317-318, 11.11.1820, in: Tutte le poesie, tutte le prose e lo Zibaldone, p. 1558: "conoscendo le illusioni, non però [...] le fuggiva o le proscriveva come i nostri pazzi filosofi, ma le cercava e la amava, anzi si faceva biasimare dagli altri antichi filosofi, appunto perchè onorava le illusioni molto più di loro".

${ }^{635}$ Cf. LEOPARDI, Giacomo. Zibaldone di pensieri, fragmento 334, 17.11.1820, in: Tutte le poesie, tutte le prose e lo Zibaldone, p. 1562.

${ }^{636}$ LEOPARDI, Giacomo. Zibaldone di pensieri, fragmento 334, 17.11.1820, in: Tutte le poesie, tutte le prose e lo Zibaldone, p. 1562: "il mondo era in uno stato di morte all'epoca della prima comparsa del Cristianesimo; che questo lo ravvivò".

${ }^{637}$ LEOPARDI, Giacomo. Zibaldone di pensieri, fragmento 335, 17.11.1820, in: Tutte le poesie, tutte le prose e lo Zibaldone, p. 1562: "Quello che uccideva il mondo, era la mancanza delle illusioni; il Cristianesimo lo salvò non come verità, ma come una nuova illusione. E gli effetti ch'egli produsse, entusiasmo, fanatismo, sagrifizi magnanimi, eroismo, sono i soliti effetti di una grande illusione". 
realidades" 638 , é que reside a "perpétua superioridade dos antigos sobre os modernos" ${ }^{639}$ e, por sua vez, a superioridade também da arte dos antigos ante aquela dos modernos. Daí a poesia, o estilo e a linguagem dos antigos, como também os sonhos e sentimentos, constituirem a eterna fonte do grande e do belo $^{640}$.

Ademais, Leopardi reconhece que a superioridade literária dos antigos se apresenta na mesma proporção da superioridade em outras coisas, por exemplo, nos costumes e na moral. Há, portanto, na abordagem leopardiana do poético, uma ampliação do universo temático e dos traços da poética, tornando-a algo que integra a história da civilização na sua totalidade complexa. Nesse sentido, essa reflexão, ou crítica poética, expressa também a interpretação de Leopardi em relação ao processo civilizatório, e sua diagnose das perdas e corrupção ao longo da civilização, mas igualmente a sua diagnose dos aspectos deletérios do presente.

Considerando a relação entre passado e presente, ele se reporta às gerações ao longo da civilização e sustenta, tendo como base a experiência moderna, que as

\begin{abstract}
gerações melhores não são aquelas à frente, mas aquelas atrás; e não existe esperança que [...] o mundo mude os costumes, e recue, ao contrário, de avançar; e avançando já não possa fazer outra coisa senão piorar. Principalmente nesses tempos e costumes presentes, não parece que possa suceder, nem derivar outra coisa que tempos e costumes piores ${ }^{641}$.
\end{abstract}

638 LEOPARDI, Giacomo. Zibaldone di pensieri, fragmento 339, 18.11.1820, in: Tutte le poesie, tutte le prose e lo Zibaldone, p. 1562: "non si consolavano mai col pensiero che queste fossero illusioni, conoscendo che in esse consiste la vita, o considerandole come tali, o come realtà".

639 LEOPARDI, Giacomo. Zibaldone di pensieri, fragmento 338, 17.11.1820, in: Tutte le poesie, tutte le prose e lo Zibaldone, p. 1562: "perpetua superiorità degli antichi sopra i moderni".

${ }^{640}$ Cf. SINGH, Ghan. Leopardi filosofo anti-filosofo, p. 134.

641 LEOPARDI, Giacomo. Zibaldone di pensieri, fragmento 307, 10.11.1820, in: Tutte le poesie, tutte le prose e lo Zibaldone, p. 1556: "generazioni migliori non sono quelle davanti, ma quelle di dietro; e non c'è speranza che [...] il mondo cambi costume, e rinculi in vece di avanzare; e avanzando già non può far altro che peggiorare. Massime a questi tempi e costumi presenti, non par che possa succedere nè derivare altro che tempi e costumi peggiori”. 
Como no universo da arte, também em outras expressões antropológicas e culturais, os Antigos revelam a sua superioridade, conforme a compreensão de Leopardi. Os Antigos eram livres, irregulares, grandes e originais, pois a poesia grega se encontrou "toda bela e formada antes do nascimento das regras" 642 .

Com a multiplicação das regras, que o progresso da razão e do saber necessariamente comporta, revela-se tal racionalidade, segundo Leopardi, inimiga de toda grandeza não só moral, mas também poética ${ }^{643}$. Ademais, a difusão do Cristianismo contribuíra também, no seu entender, para a deterioração do mundo "quanto a vida e ao belo" [quanto alla vita e al bello], reduzindo assim no homem, quer nas suas disposições gerais quer naquelas individuais, "muitos erros mais naturais e, portanto, mais vitais e nutritivos" 644 , e substituindo por outras exigências e características associadas ao modo de vida, aos costumes, ou seja, ao ethos, outras disposições como a prevenção, a prudência, mas também outras regras e restrições que salvam, ao mesmo tempo, dos erros dos Antigos, e impedem também aquele ousar com entusiasmo, vitalidade, despreocupação e naturalidade dos antigos ${ }^{645}$.

Por conseguinte, a crítica poética leopardiana ultrapassa a esfera estética, considerada na esfera apenas da arte ou da poesia se reporta ao aspecto moral das disposições antropológicas, constituídas com base na substância do ethos, revelando assim a materialidade constituidora do modo de ser e das expressões. Por isso, a grandeza e pureza da arte e da poesia dos Antigos estão associadas e inseparavelmente vinculadas ao modo de viver, sentir e conceber o próprio destino.

Para Leopardi, aquilo que fora alcançado na poesia é impossível de sêlo no mundo moderno, mas também nas expressões morais, espirituais e

${ }^{642}$ LEOPARDI, Giacomo. Zibaldone di pensieri, fragmento 308, 10.11.1820, in: Tutte le poesie, tutte le prose e lo Zibaldone, p. 1557: "tutta bella e formata prima della nascita delle regole".

${ }^{643}$ Cf. SINGH, Ghan. Leopardi filosofo anti-filosofo, p. 135.

${ }^{644}$ LEOPARDI, Giacomo. Zibaldone di pensieri, fragmento 338, 17.11.1820, in: Tutte le poesie, tutte le prose e lo Zibaldone, p. 1562: "molti errori più naturali, e quindi più vitali e nutritivi".

${ }^{645}$ Cf. SINGH, Ghan. Leopardi filosofo anti-filosofo, p. 135. 
psicológicas. Por conseguinte, no contraste entre 0 antigo ethos e a Modernidade há o pressuposto da "inimizade recíproca da razão e da natureza" [nemicizia scambievole della ragione e della natura] ${ }^{646}$, explicitada no "sistema do homem" [sistema dell'uomo] ${ }^{647}$, como aborda a reflexão leopardiana. Tal formulação esclarece, como sustenta Leopardi, algo "tão evidente e universal" [tanto evidente, e universale] ${ }^{648}$, resolvendo igualmente "infinitos mistérios e problemas na ordem e composição das coisas humanas" ${ }^{649}$. Ao se confundir, assevera Leopardi,

a razão com a natureza, o verdadeiro com o belo, os progressos da inteligência com os progressos da felicidade e com o aperfeiçoamento do homem, as noções e a natureza do útil, a finalidade ou o escopo da inteligência (que é a verdade) com a finalidade e o escopo verdadeiro do homem e da sua natureza [...] não se chega a cabo de decifrar o mistério do homem, e de conciliar as contradições infinitas que parece se encontrem nessa parte, muito essencial, do sistema universal, isto é, naquela que diz respeito a nossa espécie ${ }^{650}$.

Com tais argumentos, a reflexão leopardiana reforça, ao mesmo tempo, uma compreensão de como no processo civilizatório certas perdas possibilitou igualmente o retorno da barbárie, na medida em que ocorreram, quer no domínio da natureza quer no da relação do homem na constituição de sua vida inúmeros danos.

${ }^{646}$ Cf. LEOPARDI, Giacomo. Zibaldone di pensieri, fragmento 341, 20.11.1820, in: Tutte le poesie, tutte le prose e lo Zibaldone, p. 1563.

${ }^{647}$ Cf. LEOPARDI, Giacomo. Zibaldone di pensieri, fragmento 341, 20.11.1820, in: Tutte le poesie, tutte le prose e lo Zibaldone, p. 1563.

${ }^{648}$ Cf. LEOPARDI, Giacomo. Zibaldone di pensieri, fragmento 341, 20.11.1820, in: Tutte le poesie, tutte le prose e lo Zibaldone, p. 1563.

${ }^{649}$ LEOPARDI, Giacomo. Zibaldone di pensieri, fragmento 341, 20.11.1820, in: Tutte le poesie, tutte le prose e lo Zibaldone, p. 1563: "infiniti misteri e problemi nell'ordine e composto delle cose umane".

650 LEOPARDI, Giacomo. Zibaldone di pensieri, fragmento 341, 20.11.1820, in: Tutte le poesie, tutte le prose e lo Zibaldone, p. 1563: "la ragione con la natura, il vero col bello, i progressi dell'intelligenza coi progressi della felicità e col perfezionamento dell'uomo, le nozioni e la natura dell'utile, il fine o scopo dell'intelligenza coi progressi della felicità e col perfezionamento dell'uomo, le nozioni e la natura dell'utile, il fine o scopo dell'intelligenza (ch'è la verità) col fine e scopo vero dell'uomo e della natura sua [...] non si viene mai a capo di diciferare il mistero dell'uomo, e di accordare le infinite contraddizioni che par che s'incontrino in questa principalissima parte del sistema universale, cioè in quella che riguarda al nostra specie". 


\subsection{Decadência da civilização e barbárie}

Ao considerar antigos e modernos, a crítica poética leopardiana explicitou, como algo evidente, "uma graduação irrefutável e muito notável de grandeza, sempre em razão direta da Antiguidade" ${ }^{651}$. Desde os homens concebidos por Homero às pirâmides do Egito, descendo às proezas muito nobres e grandiosas, aos imensos trabalhos com a solidez das construções "feitas para a eternidade (algo próprio também dos baixos tempos até o século XVI e XVII), desde o profundíssimo cunho das moedas, ao heroísmo e a todos outros gêneros de grandeza que distinguem os gregos e os romanos" ${ }^{\text {"52, }}$, Leopardi seguindo dos "baixos tempos" [tempi bassi], gradativamente aos modernos, identifica "como o homem vá sensivelmente tornando-se menor, até chega a esse último grau de pequenez geral e individual, de impotência, no qual o vemos hoje" ${ }^{\prime 653}$.

Leopardi considera como "a fonte eterna do grande (como do belo)" [l'eterna fonte del grande (come del bello)], "os escritores, as obras de toda espécie, os exemplos, os costumes, os sentimentos dos antigos" ${ }^{654}$, ou seja, todo um ethos. Com base na sua observação do ethos antigo e da situação moderna ou do seu estado presente, ele reconhece que

os antigos, cada vez maiores, magnânimos, e fortes do que nós [modernos], no excesso das desventuras, na consideração das necessidades delas, da força invencível que os tornava infelizes e lhes comprimia e ligava à miséria deles sem que pudessem remediar $\mathrm{e}$ esquivar-se delas, concebiam ódio e furor contra o destino e insultavam os Deuses, declarando-se inimigos dos céus, impotentes, porém, e incapazes de vitória ou de vingança, mas nem por isso domados, nem aplacados, nem menos, aliás tão mais desejosos

${ }^{651}$ LEOPARDI, Giacomo. Zibaldone di pensieri, fragmento 340, 20.11.1820, in: Tutte le poesie, tutte le prose e lo Zibaldone, p. 1563: "una gradazione incontrastabile e notabilissima di grandezza, sempre in ragion diretta dell'antichità".

652 Ibidem: "fatte per l'eternità (cosa propria anche de' tempi bassi, e fino al cinque o secento), alla profondissima impronta delle monete, all'eroismo, e a tutti gli altri generi di grandezza che distinguono i greci, e romani".

653 Ibidem: "come l'uomo si vada sensibilmente impiccolendo, finchè giunge a quest'ultimo grado di piccolezza generale e individuale, e d'impotenza in cui lo vediamo oggidi".

654 Ibidem: "gli scrittori, le opere d'ogni sorta, gli esempi, i costumi, i sentimenti degli antichi". 
de se vingar, quanto maior era a miséria e a necessidade 655 .

Os Antigos disporiam, no entender de Leopardi, de um grau de vitalidade muito superior aos modernos, no modo de viver, de conceber e imaginar, pois "a suma de vida era maior no tempo antigo, embora ninguém, em particular, pudesse viver mais longamente daquilo que se possa viver hoje em dia, e que alguns viviam" ${ }^{656}$. Isso alimentava a imaginação dos Antigos e as ilusões deles, pois não as consideravam como tais, e contribuía, ao mesmo tempo, para formar aquilo que Leopardi denominava de "força criativa do ânimo", possuída naturalmente e espontaneamente por eles em virtude de ser do ethos antigo.

Na Modernidade, ao contrário, após o ocaso das forças das antigas ilusões, por causa do progresso da razão, do conhecimento das coisas e da verdade, na sua nulidade, o mundo tornou-se, conforme Leopardi, "filosófico, a imaginação realmente forte, verde, fecunda, criadora, abundante, não é mais peculiar senão das crianças, ou no mais dos poucos versados e pouco instruídos" 657 . Leopardi assegura que um homem de "forte e viva imaginação" [forte e viva immaginazione] dotado de um caráter avesso a pensar e aprofundar, vivendo um vigor corporal de entusiasmo, desespero, de vivíssima dor ou paixão, com embriaguez e furor, se descobrir algumas "verdades que

655 LEOPARDI, Giacomo. Zibaldone di pensieri, fragmento 504, 15.01.1821, in: Tutte le poesie, tutte le prose e lo Zibaldone, p. 1596: "gli antichi, sempre più grandi, magnanimi, e forti di noi, nell'eccesso delle sventure, e nella considerazione della necessità di esse, e della forza invincibile che li rendeva infelici e gli stringeva e legava alla loro miseria senza che potessero rimediarvi e sottrarsene, concepivano odio e furore contro il fato, e bestemmiavano gli Dei, dichiarandosi in certo modo nemici del cielo, impotenti bensì, e incapaci di vittoria o di vendetta, ma non perciò domati, nè ammansati, nè meno, anzi tanto più desiderosi di vendicarsi, quanto la miseria e la necessità era maggiore".

${ }^{656}$ LEOPARDI, Giacomo. Zibaldone di pensieri, fragmento 1332, 16.07.1821, in: Tutte le poesie, tutte le prose e lo Zibaldone, p. 1762: "la somma della vita era maggiore nel tempo antico, quantunque nessuno in particolare potesse vivere più lungamente di quello che possa viversi oggidì, e che taluni vivano".

${ }^{657}$ LEOPARDI, Giacomo. Zibaldone di pensieri, fragmento 726,08.03.1821, in: Tutte le poesie, tutte le prose e lo Zibaldone, p. 1633: "filosofo, l'immaginazione veramente forte, verde, feconda, creatrice, fruttuosa, non è più propria se non de' fanciulli, o al più de' poco esperti e poco istruiti". 
muitos séculos não bastam para a pura e fria razão geométrica" ${ }^{\text {"658, }}$, essas verdades não serão "escutadas, mas consideradas como sonhos" ${ }^{659}$.

É preciso, portanto, as condições necessárias para senti-las e compreendê-las como verdade. Grandes verdades descobriram, porém, os Antigos, segundo Leopardi, "com a grande imaginação deles, grandes saltos faziam no caminho da razão, rindo-se da lentidão e dos meios infinitos que são necessários para o puro raciocínio e experiência" ${ }^{\# 60}$. Leopardi não apenas elogia o que caracterizou o ethos antigo ante o estado presente moderno, considerando igualmente o estado civil, os costumes, os sentimentos e faculdades sensíveis, mas apresenta, ao mesmo tempo, o modo de conceber a sua diagnose do processo de civilização e as ruínas no decorrer da experiência do gênero humano.

$\mathrm{Na}$ diagnose leopardiana se revela certa compreensão da história do gênero humano, não apenas desta ou daquela nação, valendo-se de certo pensamento, relativa à decadência de um estado natural e de infância da humanidade, que a razão destruidora das ilusões originárias veio a corromper. Conforme Leopardi escreveu em um fragmento de 1821, do seu Zibaldone di pensieri:

Aquela antiga e tão famosa opinião do século de ouro
da felicidade perdida daquele tempo, onde os costumes
eram mais simples e muito rudes, e não obstante os
homens muito afortunados [...], essa opinião tão
célebre junto os antigos e os modernos, e também fora
a poesia, não pode ela [opinião] servir muito bem como
confirmação do meu sistema, demonstrando a
antiquíssima tradição de uma degeneração do homem,
de uma felicidade perdida do gênero humano, e
felicidade não consistente em outra coisa senão em um
estado de natureza, e semelhante aquele dos animais,
e não desfrutada em outro tempo que no primitivo, e

${ }^{658}$ LEOPARDI, Giacomo. Zibaldone di pensieri, fragmento 1975, 23.10.1821, in: Tutte le poesie, tutte le prose e lo Zibaldone, p. 1875: "verità che molti secoli non bastano alla pura e fredda e geometrica ragione".

659 Ibidem: "ascoltate, ma considerate come sogni".

${ }^{660}$ LEOPARDI, Giacomo. Zibaldone di pensieri, fragmento 1976, 23.10.1821, in: Tutte le poesie, tutte le prose e lo Zibaldone, p. 1875: "colla lor grande immaginazione, grandi salti facevano nel cammino della ragione, ridendosi della lentezza, e degl'infiniti mezzi che abbisognano al puro raziocinio ed esperienza". 
naquele que precedeu os inícios da civilização, aliás, as primeiras alterações da natureza humana derivadas da sociedade? ${ }^{661}$

Por conseguinte, essa ideia de degeneração constitui, como Leopardi confirma em outro passo do Zibaldone, "o principal ensino do [seu] sistema" ${ }^{\text {"62. }}$. Ademais, ainda no Zibaldone, Leopardi destaca, reportando-se à decadência de nações, civilizações e do gênero humano: "aquilo que se chama aperfeiçoamento [...] eu chamo corrupção"663. Trata-se de um percurso irreversível de uma degeneração sem limites ${ }^{664}$. A sua compreensão de decadência não se limita apenas ao percurso, mas abrange também a sua concepção de civilização. Daí Leopardi escrever em uma passagem de 1823: "os progressos da civilização levam consigo e produzem inevitavelmente a sucessiva deterioração [do homem]" ${ }^{665}$.

Leopardi não desconsidera a ideia de "progresso" e "avanço", mas tais ideias não comportam necessariamente no processo civilizatório, o sentido de "perfectibilidade" e "melhoramento", mas de corrupção. Trata-se aqui de um movimento contra si mesmo, que significa perda e queda em uma nova

${ }^{661}$ LEOPARDI, Giacomo. Zibaldone di pensieri, fragmentos 2250-2251, 13.12.1821, in: Tutte le poesie, tutte le prose e lo Zibaldone, p. 1917: "Quell'antica e si famosa opinione del secol d'oro, della perduta felicità di quel tempo, dove i costumi erano simplicissimi e rozzissimi, e non pertanto gli uomini fortunatissimi, [...] quest'opinione sì celebre presso gli antichi e i moderni poeti, ed anche fuor della poesia, non può ella molto bene servire a conferma [...] del mio sistema, a dimostrare l'antichissima tradizione di una degenerazione dell'uomo, di una felicità perduta dal genere umano, e felicità non consistente in altro che in uno stato di natura, $\mathrm{e}$ simile a quello delle bestie, e non goduta in altro tempo che nel primitivo, e in quello che precedette i cominciamenti della civilizzazione, anzi le prime alterazioni della natura umana derivate dalla società?".

662 LEOPARDI, Giacomo. Zibaldone di pensieri, fragmento 1004, 01.05.1821, in: Tutte le poesie, tutte le prose e lo Zibaldone, p. 1688: "Il principale insegnamento del [...] sistema".

${ }^{663}$ LEOPARDI, Giacomo. Zibaldone di pensieri, fragmento 1559, 25.08.1821, in: Tutte le poesie, tutte le prose e lo Zibaldone, pp. 1803-1804: "ciò che si chiama perfezionamento, [...] io chiamo corruzione".

${ }^{664}$ Cf. MUÑIZ MUÑIZ, M.D.L.N. Sul concetto di decadenza storica in Leopardi. In: /I pensiero storico e político di Giacomo Leopardi. Atti del VI Convegno Internazionale di studi leopardiani. Vol II. Set/1984, Recanati-Italia, Centro Nazioanle di Studi Leopardiani (CNSL), Firenze: OLSCHKI Editore, 1989, p. 378.

${ }^{665}$ LEOPARDI, Giacomo. Zibaldone di pensieri, fragmento 3180, 17.08.1823, in: Tutte le poesie, tutte le prose e lo Zibaldone, p. 2079; "i progressi della civiltà portano seco e producono inevitabilmente il sucessivo deterioramento [...]". 
barbárie. Esse é o que caracteriza, de acordo com os versos da Ginestra [1836], o presente como "século soberbo e tolo" [secol superbo e sciocco] ${ }^{666}$.

Quando Leopardi pensa a decadência do gênero humano, destaca, ao mesmo tempo, a impossibilidade de toda retomada do estado natural originário. Nesse sentido, ele escreve: "as gerações melhores não são aquelas à frente, mas aquelas atrás; e não há esperança que [...] o mundo mude costumes e recue, ao contrário de avançar" ${ }^{\prime 67}$. Pode-se ainda indicar outros passos do Zibaldone di pensieri onde Leopardi reforça essa ideia de impossibilidade de recuo da civilização. Em 8 de março de 1821, ele afirma: "Desejaria também que o tempo voltasse. Mas a nossa infelicidade e o conhecimento que temos das coisas, e [que] não deveríamos ter, ao contrário de diminuir, cresce" ${ }^{\text {"668. }}$.

Já em outro momento do Zibaldone, Leopardi também sustenta:

Querendo com todo o máximo esforço remeter-se ao estado natural, não poderíamos, nem quanto ao físico, que não o suportaria, de modo algum, nem, dado que se pudesse quanto ao físico e externamente, poder-seia quanto ao moral e internamente ${ }^{669}$.

Mais adiante, ele acrescenta ainda, reforçando qualquer possibilidade de retorno ou recuperação dos danos, que,

para nós, corruptos e degenerados uma vez, não se encontra mão que nos reponha no primeiro estado, (nem por nós mesmos estamos aptos para fazê-lo). Dado que nem a natureza nos recupera pela mão para nos formar, com o artífice o seu trabalho estragado,

\footnotetext{
${ }^{666}$ Cf. LEOPARDI, Giacomo. La Ginestra o il fiore del deserto, v. 53, in: Canti, a cura di Ugo Dotti, p. 449.

${ }^{667}$ LEOPARDI, Giacomo. Zibaldone di pensieri, fragmentos 306-307, 10.11.1820, in: Tutte le poesie, tutte le prose e lo Zibaldone, p. 1556: "Le generazione migliori non sono quelle davanti, ma quelle di dietro; e non c'è speranza che [...] il mondo cambi costume, e rinculi in vece di avanzare".

${ }^{668}$ LEOPARDI, Giacomo. Zibaldone di pensieri, fragmento 727, 08.03.1820, in: Tutte le poesie, tutte le prose e lo Zibaldone, p. 1633; "Vorrei che anche i tempi ritornassero indietro. Ma la nostra infelicità, e la cognizione che abbiamo, e non dovremmo aver, delle cose, in vece di scemare, si accresce".

${ }^{669}$ LEOPARDI, Giacomo. Zibaldone di pensieri, fragmento 2403, 29.04.1822, in: Tutte le poesie, tutte le prose e lo Zibaldone, p. 1944: "volendo con ogni massimo sforzo rimetterci nello stato naturale, non potremmo, nè quanto al fisico, che non lo sopporterebbe in verun modo, nè posto che si potesse quanto al fisico ed esternamente, si potrebbe quanto al morale ed internamente".
} 
nem outra potência existe que nos possa restaurar como um novo artífice o trabalho de outros" 670 .

Nesta nova passagem, Leopardi retoma o argumento de que:

a natureza não se substitui, não mais de uma única perfeição (ou seja, do seu estado natural) pode estabelecer para nenhuma espécie de ser criado e, portanto, não mais de uma felicidade ${ }^{671}$.

Para Leopardi, o estado presente, ou seja, o da Modernidade, se apresenta sob uma dupla catástrofe: de um lado, a queda (ou nova queda) na barbárie e, de outro, o abandono àquela progressão do fracasso civilizatório, fruto do processo de aceleração a ponto de uma inércia. O seguinte passo do Zibaldone indica também certas previsões leopardianas quanto ao processo civilizatório. Segundo Leopardi escreve:

Para se falar de novo daqui a cem anos. Não temos ainda exemplo nas idades passadas, dos progressos de um processo civilizatório desmedido, e de uma desnaturação sem limites, mas senão recuamos, os nossos descendentes deixarão esse exemplo aos pósteros, se terão pósteros" ${ }^{\prime 72}$.

Reportando-se à civilização presente, Leopardi argumenta:

ou fará [...] novos progressos, ou recuará. Um limite, uma meta (segundo os filósofos) não se pode ver, e não existe. Muito menos um ponto mediano [...]. Tudo é incerto e falta norma e modelo, desde que nos afastamos da natureza, única forma e razão do modo de $\operatorname{ser}^{673}$.

${ }_{670}^{67 E O P A R D I}$, Giacomo. Zibaldone di pensieri, fragmento 2903, 06.07.1823, in: Tutte le poesie, tutte le prose e lo Zibaldone, p. 2030: "a noi guasti e snaturati una volta, non si trova mano che ci riponga nel primo stato, (nè da noi medesimi siamo atti a farlo). Poichè nè la natura ci ripiglia in mano per riformarci, come l'artefice il suo lavoro sconciato, nè altra potenza v'ha che ci possa restaurare com un nuovo artefice il lavoro altrui".

671 LEOPARDI, Giacomo. Zibaldone di pensieri, fragmento 3778, 25-30.11.1820, in: Tutte le poesie, tutte le prose e lo Zibaldone, p. 2193: "la natura non si rimpiazza, nè più d'una sola perfezione (cioè del suo naturale stato) può convenire a niuna specie d'esseri creati, e quindi non più d'una felicità".

${ }^{672}$ LEOPARDI, Giacomo. Zibaldone di pensieri, fragmento 217, 18-20.08.1820, in: Tutte le poesie, tutte le prose e lo Zibaldone, p. 1537: "A riparlarci di qui a cent'anni. Non abbiamo ancora esempio nelle passate età, dei progressi di un incivilimento smisurato, e di un snaturamento senza limiti. Ma se non torneremo indietro, i nostri discendenti lasceranno questo esempio ai loro posteri, se avranno posteri".

${ }^{673}$ LEOPARDI, Giacomo. Zibaldone di pensieri, fragmento 1613, 02.09.1821, in: Tutte le poesie, tutte le prose e lo Zibaldone, p. 1813: "o farà [...] nuovi progressi, o tornerà indietro. Un limite, una meta (secondo i filosofi) non si può vedere, e non v'è. Molto meno un punto di 
Conforme Leopardi, o andamento ou dito "aperfeiçoamento do espírito humano se assemelha totalmente à progressão geométrica, que do mínimo termo, com proporção crescente, chega ao infinito" 674 . Quanto à relação entre processo civilizatório e corrupção, Leopardi afirma:

a estreita precisão das leis, instituições, estatutos, governos [...], em suma as coisas, cresceu sempre em proporção que os homens e os séculos têm sido mais corrompidos: e agora veio ao ápice, porque também a corrupcão é excessiva e tem passado todos os limites $^{675}$.

Em seguida, Leopardi argumenta sobre os limites da corrupção na civilização, e assegura que:

Passada foi a corrupção social, de longe, além da metade, e chegada, pode-se dizer, ao seu cume, no qual hoje em dia se encontra e repousa, e é, aquilo que parece, para repousar longamente ou perpetuamente [...], nascem, pode-se dizer, os homens já corrompidos $^{676}$.

Disso resulta o risco de uma queda na barbárie ou nova barbárie, que pressupõe um infinito progresso, o qual eterniza, por sua vez, a corrupção e, de certo, uma regressão histórica na expressão da barbárie. Trata-se do resultado igualmente de uma natureza desnaturada, tornando igualmente "caverna", as "cidades". Como Leopardi escreve no Zibaldone di pensieri:

Após aquele tempo, quando à son tour a civilização tornada hoje tão vasta e poderosa conquistadora, não terá nada para conquistar, então se retornará à

mezzo. [...]. Tutto è incerto e manca di norma e di modello, dacchè ci allontaniamo da quello della natura, unica forma e ragione del modo di essere".

${ }^{674}$ LEOPARDI, Giacomo. Zibaldone di pensieri, fragmento 924, 15.10.1821, in: Tutte le poesie, tutte le prose e lo Zibaldone, p. 1867: "perfezionamento dello spirito umano rassomiglia interamente alla progressione geometrica che dal menomo termine, con proporzione crescente arriva all'infinito".

${ }^{675}$ LEOPARDI, Giacomo. Zibaldone di pensieri, fragmento 583, 29-31.01.1821, in: Tutte le poesie, tutte le prose e lo Zibaldone, p. 1610: "la stretta precisione delle leggi, istituzioni, statuti governi [...] insomma delle cose, è sempre cresciuta in proporzione che gli uomini e $i$ secoli sono stati più guasti: ed ora è venuta al colmo, perchè anche la corruzione è eccessiva, e ha passato tutti i limiti".

${ }^{676}$ LEOPARDI, Giacomo. Zibaldone di pensieri, fragmento 3522, 25.09.1823, in: Tutte le poesie, tutte le prose e lo Zibaldone, p. 2143: "Passata che fu la corruzione sociale di gran lunga oltre il mezzo, e giunta, si può dire, al suo colmo, nel quale oggidì si trova e riposa, ed è, a quel che sembra per riposar lungamente o in perpetuo [...]; nascono, si può dir, gli uomini già corrotti". 
barbárie, e, será possível, à natureza por uma nova estrada, e totalmente oposta à natural, isto é, a estrada da corrupção universal como nos baixos tempos; e eu não sei prognosticar mais além daquilo que se deverá esperar. O mundo então começará um outro curso, e quase uma outra essência e existência"677.

Deve-se aqui ressaltar a complexidade desse conceito de barbárie, pois, ao mesmo tempo em que Leopardi identifica o primitivo pertencente ao estado natural, também o associa ao "corrupto", pertencente à civilização ${ }^{678}$. Daí Leopardi afirmar: "uma coisa é o primitivo outra é o bárbaro. O bárbaro é já corrupto, o primitivo ainda não é maduro" ${ }^{\text {"79 }}$.

Para Leopardi, a barbárie se apresenta não apenas como o resultado imediato do processo civilizatório, ou seja, ela vem após o excesso de civilização" [vien dopo l'eccesso di civiltà], mas se apresenta ainda como algo insuperável desse processo, pois a excessiva civilização sempre conduziu os povos à barbárie, ao contrário de precedê-la imediatamente, ou melhor, participado dela. A perfeita civilização não pode subsistir, no entender de Leopardi, "sem a perfeita barbárie" [senza la barbarie perfetta] ${ }^{680}$, ou ainda, a barbárie pressupõe "um princípio de civilização, uma civilização iniciada, imperfeita, ou melhor a inclui" [un principio di civiltà, una civiltà incoata, imperfetta; anzi l'include] $]^{681}$.

677 LEOPARDI, Giacomo. Zibaldone di pensieri, fragmento 867, 24.03.1821, in: Tutte le poesie, tutte le prose e lo Zibaldone, pp. 1656-1657: "Dopo quel tempo, quando à son tour la civiltà divenuta oggi sì rapida vasta e potente conquistatrice, non avrà più nulla da conquistare, allora o si tornerà alla barbarie, e se sarà possibile, alla natura per una nuova strada, e tutta opposta al naturale, cioè la strada dell'universale corruzione come ne' bassi tempi; o io non so pronosticare più oltre quello che si dovrà aspettare. II mondo allora comincerà un altro andamento, e quasi un'altra essenza ed esistenza".

${ }^{678}$ Cf. MUÑIZ MUÑIZ, M.D.L.N. Sul concetto di decadenza storica in Leopardi. In: /I pensiero storico e político di Giacomo Leopardi. Atti del VI Convegno Internazionale di studi leopardiani. Vol II. Set/1984, Recanati-Italia, Centro Nazioanle di Studi Leopardiani (CNSL), Firenze: OLSCHKI Editore, 1989, p. 379.

${ }^{679}$ LEOPARDI, Giacomo. Zibaldone di pensieri, fragmento 118, 09.06.1820, in: Tutte le poesie, tutte le prose e lo Zibaldone, p. 1511: "Altro è primitivo altro è barbaro. II barbaro è già guasto, il primitivo ancora non è maturo".

${ }^{680}$ Cf. LEOPARDI, Giacomo. Zibaldone di pensieri, fragmento 1173, 16.06.1821, in: Tutte le poesie, tutte le prose e lo Zibaldone, p. 1726.

681 Cf. LEOPARDI, Giacomo. Zibaldone di pensieri, fragmento 4185, 07.07.1826, in: Tutte le poesie, tutte le prose e lo Zibaldone, p. 2311. 
Destaca-se na reflexão de Leopardi sobre o processo de civilização e de seu aperfeiçoamento, certos questionamentos acerca de numerosos esforços realizados para se obter certo grau de aperfeiçoamento às custas, às vezes, de sofrimentos, escravidão e morte. Daí ele indagar se a natureza podia, de forma razoável, pôr tão grandes obstáculos para se encontrar meios necessários, a fim da "perfeição e da felicidade do gênero humano, isto é, o processo de civilização"682.

Nesse processo de aperfeiçoamento, Leopardi se reporta aos "esforços imensos e misérias que são necessários para obter a moeda para a sociedade" ${ }^{\prime 683}$. Ele observa os esforços despendidos com o sacrifício de tantas vidas na extração dos metais até o cunho da moeda. Leopardi se indigna em virtude de tantos sacrifícios perpetrados com base no ideal de civilidade:

Observai quantos homens são preciso para uma regular e estável felicidade, para doenças, para mortes, para escravidão (ou gratuita e violenta, ou mercenária), para desastres, misérias, penas, esforços de toda espécie, para obter para outros homens esse pretenso meio de civilização, e pretenso meio de felicidade ${ }^{684}$.

Ante essas "contradições" [contraddizioni] ${ }^{655}$, ele revela a sua indignação, sobretudo, em admitir que a natureza haja posto, a esse preço, o princípio da perfeição e da felicidade, ou seja, "ao preço da infelicidade regular da metade dos homens (e digo uma metade, considerando não só essa, mas também os outros ramos da pretensa perfeição social, que custam o mesmo preço" ${ }^{\text {"686 }}$. Daí os excessos de civilização e aperfeiçoamento civil suscitarem,

$\overline{682}$ LEOPARDI, Giacomo. Zibaldone di pensieri, fragmentos 1171-1172, 16.06.1821, in: Tutte le poesie, tutte le prose e lo Zibaldone, p. 1726: "perfezione e felicità del genere umano, cioè l'incivilimento".

683 LEOPARDI, Giacomo. Zibaldone di pensieri, fragmento 1172, 16.06.1821, in: Tutte le poesie, tutte le prose e lo Zibaldone, p. 1726: "immense fatiche e miserie che son necessarie per proccurar la moneta alla società".

${ }^{684}$ Ibidem: "Osservate quanti uomini sono necessitati ad una regolare e stabile infelicità, a malattie, a morti, a schiavitù (o gratuita e violenta, o mercenaria) a disastri, a miserie, a pene, a travagli d'ogni sorta, per proccurare agli altri uomini questo mezzo di civiltà, e preteso mezzo di felicità".

685 Cf. LEOPARDI, Giacomo. Zibaldone di pensieri, fragmento 1173, 16.06.1821, in: Tutte le poesie, tutte le prose e lo Zibaldone, p. 1726.

${ }^{686}$ LEOPARDI, Giacomo. Zibaldone di pensieri, fragmento 1172, 16.06.1821, in: Tutte le poesie, tutte le prose e lo Zibaldone, p. 1726: "al prezzo dell'infelicità regolare di una metà 
no seu pensamento, a ideia da perfeita barbárie: misérias convenientes àquela mesma civilização à qual serve. Leopardi contesta a defesa da escravidão por muitos políticos, os quais defendem "como necessária à comodidade, à perfeição, ao bem, à civilização da sociedade" 687 .

Com base em uma observação das contradições do ideal de civilização e em suas consequências no mundo moderno, Leopardi contesta a falsidade das teorias que justificam as atrocidades. Elas expressam a falsidade do ideal de "perfeição da sociedade" [perfezione della società] ${ }^{688}$ :

como a civilização (segundo o costume de todas as falsas teorias) contradiga a si mesma também em teoria, e além disso não possa subsistir sem circunstâncias que repugnam à sua natureza, e são absolutamente incivis, ou melhor bárbaras, na verdade como um todo e na força do termo ${ }^{689}$.

Por conseguinte, a "perfeita civilização" [perfetta civiltà] ${ }^{690}$ está vinculada à perfeita barbárie. Para Leopardi, se natureza e barbárie em seu sentido originário não é igual à civilização, no estado presente moderno barbárie e civilização não é idêntico à natureza. Por isso, a perfeição da sociedade se vincula à imperfeição, pois eliminada essa imperfeição se eliminaria as raízes da pretensa perfeição social. Daí Leopardi retornar então à indagação sobre tais contradições e absurdos ${ }^{691}$. Indaga se essa via tivesse sido ordenada pela

degli uomini. (e dico una metà, considerando non solo questo, ma anche gli altri rami della pretesa perfezione sociale, che costano il medesimo prezzo)".

${ }^{687}$ LEOPARDI, Giacomo. Zibaldone di pensieri, fragmentos 1172-1173, 16.06.1821, in: Tutte le poesie, tutte le prose e lo Zibaldone, p. 1726: "come necessaria al comodo, alla perfezione, al bene, alla civiltà della società".

${ }^{688}$ Cf. LEOPARDI, Giacomo. Zibaldone di pensieri, fragmento 1173, 16.06.1821, in: Tutte le poesie, tutte le prose e lo Zibaldone, p. 1726.

${ }^{689}$ LEOPARDI, Giacomo. Zibaldone di pensieri, fragmento 1173, 16.06.1821, in: Tutte le poesie, tutte le prose e lo Zibaldone, p. 1726: "come la civiltà (secondo il costume di tutte le false teorie) contraddica a se stessa anche in teorica, ed oltracciò non possa sussitere senza circostanze che ripugnano alla sua natura, e sono assolutamente incivili, anzi barbare in tutta la veritá e la forza del termine".

${ }^{690}$ Cf. LEOPARDI, Giacomo. Zibaldone di pensieri, fragmento 1173, 16.06.1821, in: Tutte le poesie, tutte le prose e lo Zibaldone, p. 1726.

${ }^{691}$ Cf. LEOPARDI, Giacomo. Zibaldone di pensieri, fragmento 1173, 16.06.1821, in: Tutte le poesie, tutte le prose e lo Zibaldone, p. 1726. 
natureza para que fosse obtida a perfeição, ou seja, o bem estar "da principal criatura terrena" [principal criatura terrena ${ }^{692}$, ou seja, o homem.

A "perfeição do estado social" [perfezione dello stato sociale] ${ }^{693}$ é uma contradição para Leopardi, em especial, quando ele destaca o uso da moeda, pois prejudica aquela perfeição. Em tal uso se revelam os obstáculos para a conservação da igualdade entre os homens e, portanto, dos "estados livres" [stati liberi ${ }^{694}$, pois compromete o verdadeiro mérito e a virtude. Isso porque, "pouco a pouco obriga a sociedade à opressão, ao despotismo, à servidão, à gravitação de umas classes sobre as outras, em suma, extinguem a vida moral e íntima das nações e as nações mesmas enquanto eram nações" 695 .

Aquilo que ocorre com o uso da moeda e suas consequências no estado social, vale também para outros usos que Leopardi observa, de um lado, como necessários a essa perfeição da sociedade e da civilização, mas, de outro, os seus efeitos nefastos para a conservação do indivíduo e do gênero humano. Portanto, o excesso de objetos de luxo para estimular o comércio, tão necessário à civilização e, sobretudo, quando não sejam em si mesmo tão necessários e úteis à vida, revela, em verdade, uma contradição implícita ao aperfeiçoamento social e civilizatório, pois custam esforços infinitos para a humanidade. Daí Leopardi observar de forma insistente,

como seja necessária à civilização a incivilidade, à perfeição a imperfeição (no sentido no qual chamamos perfeição o seu contrário), à humanidade, à delicadeza e ao requinte [...] a barbárie da sociedade ${ }^{696}$.

${ }^{692}$ Cf. LEOPARDI, Giacomo. Zibaldone di pensieri, fragmento 1173, 16.06.1821, in: Tutte le poesie, tutte le prose e lo Zibaldone, p. 1726.

${ }^{693}$ Cf. LEOPARDI, Giacomo. Zibaldone di pensieri, fragmento 1174, 16.06.1821, in: Tutte le poesie, tutte le prose e lo Zibaldone, p. 1726.

${ }^{694}$ Cf. LEOPARDI, Giacomo. Zibaldone di pensieri, fragmento 1174, 16.06.1821, in: Tutte le poesie, tutte le prose e lo Zibaldone, p. 1726.

${ }^{695}$ LEOPARDI, Giacomo. Zibaldone di pensieri, fragmento 1174, 16.06.1821, in: Tutte le poesie, tutte le prose e lo Zibaldone, p. 1726: "apocco apocco costringono la società all'oppressione, al dispotismo, alla servitù, alla gravitazione delle une classi sulle altre, insomma estinguono la vita morale ed intima delle nazioni, e le nazioni medesime in quanto erano nazioni".

${ }^{696}$ LEOPARDI, Giacomo. Zibaldone di pensieri, fragmento 1183, 16.06.1821, in: Tutte le poesie, tutte le prose e lo Zibaldone, p. 1728: "come sia necessaria alla civiltà l'inciviltà, alla perfezione l'imperfezione (nel senso in cui chiamiamo perfezione il suo contrario), alla umanità e delicatezza e raffinatezza [...] la barbarie della società". [Grifo nosso]. 
Poder-se-ia aqui completar com a conclusão desoladora de Leopardi, presente ao final da "História do gênero humano" [Storia del genero umano], as Operette morali, uma vez que os mortais aparecem imersos, após descoberta a funesta verdade, "naquela suprema miséria que eles sustentam até agora e sempre sustentarão"697. Trata-se de uma conclusão na qual se poderia igualmente avistar a realização da profecia da barbárie formulada na canção "A um vencedor nos Jogos" [ $A$ un vincitore nel pallone]: "Passarão sóis, e a cidade latina/ Habitará a raposa, e o indomado/ Bosque murmurará de muro a muro"698.

\subsection{Ante o maquiavelismo de sociedade: chamar as coisas pelos} nomes

Se a reflexão sobre a decadência e a corrupção destacou, naquelas passagens do Zibaldone di pensieri, a problemática das contradições presentes no ideal de perfeição da civilização e suas consequências na sociedade, apresenta-se também na obra de Leopardi uma crítica da vida social com base na ideia de "Maquiavelismo de sociedade" [Macchiavellismo di società]. Destaca-se, no sentido dessa crítica, os seus Pensieri [1845], pois, nessa obra, assim como em outras do último período, Leopardi se revela como "propagador e, ao mesmo tempo, denunciador desse código do verdadeiro promulgado por Maquiavel com coragem e honestidade suprema"699. Essa atitude expressa a falsidade e vacuidade das máximas morais, dos retores de profissão e dos moralistas profissionais. Se se considera certo teor dessa crítica de Leopardi dos Pensieri e no Zibaldone, pode-se compreender a sua ironia contra a ambiguidade e falsidade desses moralistas profissionais.

No conteúdo desses discursos, Leopardi identifica essa ambiguidade e falsidade: "Virtude significa hipocrisia, ou seja, incompetência; razão, direito e

${ }^{697}$ LEOPARDI, Giacomo. Operette morali, pp. 81-82: "in quella suprema miseria che eglino sostengono insino ad ora, e sempre sosterranno".

${ }^{698}$ LEOPARDI, Giacomo, A un vincitore nel pallone, vv. 43-46, in: Canti [1818-1835], p. 251: " [...] e pochi Soli/ Forse fien volti, e le città latine/ Abiterà la cauta volpe, e l'altro/ Bosco mormorerà fra le alte mura". Ver ainda, MUÑIZ MUÑIZ, M.D.L.N. Sul concetto di decadenza storica in Leopardi. In: II pensiero storico e político di Giacomo Leopardi. Atti del VI Convegno Internazionale di studi leopardiani. Vol II, p. 378.

${ }^{699}$ Cf. CASERTA, Ernesto G. L'ultimo Leopardi: pensiero e poesia. Roma: Bonacci Editore, 1980, p. 43. 
similares significam força; bem, felicidade [...] dos súditos significa vontade, capricho, vantagem [...] do soberano"700. Daí Leopardi se perguntar a razão de alguns quererem adotar essa linguagem obscura, a qual confunde as ideias, engana e, sobretudo, embaralha a mente de quem ler. Ele mesmo, ao pretender ser útil mais do que se possa, buscou uma "linguagem clara" [linguaggio chiaro] ${ }^{701}$ para usar na sua escrita. "Por que não se tem de chamar as coisas com os nomes delas? [...]. Por que da patifaria (isto, é, do saber viver) tem-se de tratar e escrever com o vocabulário da moral?"702.

Para Leopardi, o respeito pela verdade e o compromisso ético exige que se chamem as coisas "com os nomes delas" [co'i nomi loro], ou seja, de corresponder as palavras com os fatos. Por conseguinte, "de ser claro no escrever como todos enfim eram, e muito mais são claros no fazer"703. É importante destacar a denuncia leopardiana à falsa cultura e ao falso saber, mas, ao mesmo tempo, o seu protesto contra uma sociedade organizada, de forma ardilosa, interessada apenas em preservar as aparências do verdadeiro, que conhecer e enfrentar a realidade ${ }^{704}$. Daí se poder identificar na Novela Xenofontes e Nicolau Maquiavel [1906], pertencente às Operette morali, um primeiro esboço da concepção leopardiana de "maquiavelismo de sociedade". Nessa Novella, Leopardi alinha-se com Maquiavel e defende sem artifícios retóricos e equívocos que Maquiavel e não Xenofontes diz a verdade.

Xenofontes como tantos moralistas e teóricos
semelhante a Fénelon, usou a língua da Retórica,
enfeitando sermões e mentiras que ninguém, nem
mesmo os próprios moralistas põem em prática. A
verdade descoberta e cientificamente definida de
Maquiavel, ao contrário, rebate Leopardi, se ajusta aos

$\overline{700}$ LEOPARDI, Giacomo, Novella Senofonte e Niccolò Machiavello, in: Operette morali, pp. 544-545: "virtù significa hipocrisia, ovvero dappocaggine; ragione, diritto e simili significano forza; bene, felicità [...] dei sudditi significa volontà, capriccio, vantaggio [...] del sovrano". Ver ainda CASERTA, Ernesto G. L'ultimo Leopardi: pensiero e poesia, p. 43. morali, p. 545.

701 Cf. LEOPARDI, Giacomo, Novella Senofonte e Niccolò Machiavello, in: Operette

702 LEOPARDI, Giacomo, Novella Senofonte e Niccolò Machiavello, in: Operette morali, p. 545: "Perchè non s'hanno da chiamare le cose coi loro nomi? [...] Perchè l'arte della scelleraggine (cioè del saper vivere) s'ha da trattare e scrivere col vocabolario della morale?" nel fare".

${ }^{703}$ Ibidem: "d'esser chiaro nello scrivere come tutti oramai erano e molto più sono chiari

${ }^{704}$ Cf. CASERTA, Ernesto G. L'ultimo Leopardi: pensiero e poesia, p. 42. 
fatos, corresponde à vida real; enquanto é fácil pregar a virtude, fazer panegíricos à maneira daquilo que fez Plínio a Trajano ou Xenofontes a Ciro. Nesse caso se mente: fecham-se os olhos à realidade, às verdadeiras leis que regulam a vida do indivíduo e da sociedade ${ }^{705}$.

Ao se ignorar ou refutar a presença dessas leis na sociedade, como Leopardi denuncia nesse escrito e nos Pensieri, seria o mesmo que manter os olhos vendados ou viver como hipócrita. Sobre aqueles que pretenderam ensinar aos homens o saber viver, não sendo senão a finalidade de todo exercício da disciplina, Leopardi declara por meio de Maquiavel:

Caíram em um desses dois erros. O primeiro, e principal, e mais comum é o de ter pretendido ensinar a viver (seja no trono ou de forma privada) a governar a si mesmo ou aos outros, segundo os preceitos daquela que se chama moral. Pergunto eu: é verdade ou não é verdade que a virtude é o patrimônio dos estúpidos [...]. É verdade ou não é verdade que para viver, para não ser vítima de todos, pisado, escarnecido e subjugado sempre por todos (mesmo com o maior engenho, valor, coragem, cultura e capacidade natural ou adquirida para superar os outros), é absolutamente necessário ser trapaceiro: que o jovem até que não aprendeu a sêlo, se encontra sempre maltratado; e nunca chega à nada $[?]^{706}$.

A novela revela traços autobiográficos das vicissitudes de Leopardi no trato cotidiano e de uma experiência amarga fruto de uma convivência tribulada no seu tempo. Trata-se, portanto, da descoberta de uma realidade brutal, na qual ele refuta todas as mentiras repetidas ao longo do tempo, de inércia, conformismo e conveniências.

Maquiavel-Leopardi se confronta com Xenofontes, que na Novella representa a moral falsa e vazia:

${ }^{705}$ Cf. CASERTA, Ernesto G. L'ultimo Leopardi: pensiero e poesia, p. 40.

${ }^{706}$ LEOPARDI, Giacomo, Novella Senofonte e Niccolò Machiavello, in: Operette morali, p. 542: "son caduti in uno di questi due errori. II primo, e principale, e più comune si è d'aver voluto ammaestrare a vivere (sai sul trono o privatamente) e governar se stesso o gli altri, secondo i precetti di quella che si chiama morale. Domando io: è vero o non è vero che la virtù è il patrimonio dei coglioni [...]. È vero o non è vero che per vivere, per non esser la vittima di tutti, e calpestato e deriso e soverchiato sempre da tutti (anche col più grande ingegno e valore e coraggio e coltura, e capacità naturale o acquisita di superar gli altri), è assolutissimamente necessário d'esser birbo: che il Giovane finché non há imparato ad esserlo, si trova sempre malmenato, e non cava un ragno da un buco in eterno [?]" 
O fato é que não por outra coisa o meu livro prevaleceu na opinião dos homens sobre o teu, aquele de Fénelon e a todos os livros políticos, se não porque eu digo simplesmente aquelas coisas que são verdadeiras, que fazem, que se farão sempre, e que são feitas, e os outros dizem o oposto, embora saibam e vejam também eles nada menos do que eu, que as estão como eu digo. De maneira que os livros deles são como aqueles dos sofistas: tantos exercícios escolásticos, inúteis à vida, e com a finalidade que se propõem, isto é, instruí-la porque compostos de preceitos ou de sentenças conscientemente e intencionalmente falsas, não praticadas nem podido praticar por quem as escreve, muito prejudiciais a quem as praticasse, mas realmente não praticadas nem mesmo por quem as lê, se ele não é um jovem inexperiente, ou um incapaz. Enquanto o meu livro é e será sempre o Código do verdadeiro, único, infalível e modo universal de viver, e por isso sempre muito celebrado, mais pela ousadia ou, ao contrário, a coerência por mim usado no escrevê-lo que, porque fosse preciso muito para pensar e dizer aquilo que todos sabem, todos vêem e todos fazem ${ }^{707}$.

A crítica leopardiana expressa nesse escrito, por meio de Maquiavel, revela uma experiência que pressupõe o convívio desde a casa, a aldeia nativa, nas várias cidades italianas visitadas por ele, observando ao mesmo tempo de perto, aquilo que se vela por trás das máscaras. Diante de um século "soberbo e tolo" [superbo e sciocco], Leopardi assumia as consequências da sua postura, identificando nessa sociedade a presença do egoísmo e a recíproca prepotência. Dessa experiência de tensão e conflito decorre a sua formulação do maquiavelismo ético social, algo desenvolvido nas suas reflexões dos Pensieri.

${ }^{707}$ LEOPARDI. Giacomo, Novella Senofonte e Niccolò Machiavello, in: Operette morali, p. 544: "Fato sta che non per altro il mio libro è prevaluto nell'opinione degli uomini al tuo, $a$ quello del Fénélon e a tutti i libri politici, se non perch'io dico nudamente quelle cose che son vere, che si fanno, che si faranno sempre, e che vanno fatte, e gli altri dicono tutto l'oposto, benché sappiano e vedano anch'essi niente meno di me, che le cose stanno come le dico io. Sicché i libri loro sono come quelli de' sofisti: tante esercitazioni scolastiche, inutili alla vita, e al fine che si propongono, cioè d'estruirla; perché composti di precetti o di sentenze scientemente e volutamente false, non praticate né potute praticare da chi I escrive, dannosissime a chi le praticasse, ma realmente non praticate neppure da chi le legge, s'egli non è un Giovane inesperto, o un dappoco. Laddove il mio libro è e sarà sempre il Codice del vero ed único e infallibile e universal modo di vivere, e perciò sempre celebratissimo, più per l'ardire, o piuttosto la coerenza da me usata nello scriverlo, che perché ci volesse molto a pensare e dir quello che tutti sanno, tutti vedono, e tutti fanno". 
Não obstante não se tratar de uma obra sistemática, pode-se encontrar nela uma orientação de moral social, ou seja, o do Maquiavelismo ético-social: orientação que já se revela no aforismo $1^{\circ}$ dos seus Pensieri. Ao principiar, Leopardi diz de haver "recusado longamente acreditar como verdadeiras as coisas" ${ }^{708}$, que ele dirá em tal obra, porque a [sua] natureza estava muito distante delas e que "o ânimo tende sempre a julgar os outros a partir de si mesmo" 709 , e que a sua inclinação não foi jamais a de "odiar os homens, mas de amá-los. Por último, a experiência quase que violentamente persuadiu-melas ${ }^{1710}$. Ademais, ele assegura de poder ser compreendido por aqueles leitores que conviveram com diversos homens e de diversos modos. Outros pensariam inclusive de ele haver exagerado em suas observações: "até que a experiência, se por acaso terão ocasião de realmente fazer experiência da sociedade humana"711.

Para Leopardi, "o mundo é uma liga de patifes contra os homens de bem, e de vis contra os generosos" ${ }^{\text {"112 }}$. Daí a presença de uma divisão na sociedade em dois grupos: uns usam a prepotência e os outros a sofrem. Ele infere essa lei da sua experiência com os homens em sociedade, e com base em uma longa reflexão sobre a história do gênero humano, considerando-a como um fenômeno natural, ou seja, fazendo parte da realidade social mesma. Para Leopardi, essa divisão é algo inevitável. Daí escrever no aforismo $28^{\circ}$ dos Pensieri:

nem lei, nem força alguma, nem progresso da Filosofia, nem de civilização podendo impedir que o homem nascido ou por nascer, não seja ou de uns ou de

\footnotetext{
${ }_{708}$ LEOPARDI, Giacomo. Pensieri, aforismo $1^{\circ}$, a cura di Antonio Prete, p. 31: "ricusato di creder vere le cose".

709 LEOPARDI, Giacomo. Pensieri, aforismo $1^{\circ}$ a cura di Antonio Prete, p. 31: "I"animo tende sempre a giudicar gli altri da se medesimo".

710 Ibidem: "odiare gli uomini, ma di amarli. In ultimo l'esperienza quase violentemente me le ha persuase".

${ }^{711}$ Ibidem: "finché l'esperienza, se mai avranno ocasione di veramente fare esperienza della società umana".

712 Ibidem: "il mondo è una lega di birbanti contro gli uomini da bene, e di vili contro i generosi".
} 
outros, resta que quem pode eleger, eleja. Verdade é que nem todos podem, nem sempre ${ }^{713}$.

Após apresentar tal lei universal, que regula naturalmente a disposição dos homens em sociedade, Leopardi explicita exemplos concretos, ou seja, as leis específicas desse maquiavelismo ético-social. Ele considera, de início, a opressão familiar, pois se se observa a vida de alguns homens ilustres, são pouquíssimos aqueles "realmente grandes, aos quais não tenha faltado o pai na primeira idade" ${ }^{\prime 14}$. O poder paterno em todas as nações, que possuem leis, leva a uma espécie de escravidão dos filhos, e por ser doméstica é muito mais estreita e mais sensível do que a civil ${ }^{715}$.

Não obstante se tratar de uma "orientação experiente e amorosa" [guida esperta e amorosa $]^{716}$, permanece a presença da autoridade e o seu papel de pai-senhor. Aqui se apresenta o

protesto contra essa liga para delinquir entre família e sociedade, entre o pai-senhor e os órgãos políticosociais, com prejuízos para os jovens e ingênuos, que assume nos Pensieri a forma de um drama pessoal e, ao mesmo tempo, de uma tragédia universal: a humanidade condenada à opressão e a dor de uma lei cósmica, cuja origem e cujo fim fogem à compreensão humana, mas cujas marcas indeléveis se encontra em toda parte ${ }^{717}$.

A diagnose leopardiana presente nos Pensieri, e a crítica às formas de maquiavelismo social, se revelam como um conhecimento fundado na realidade imediata, as quais se opõem às formas de filosofia abstrata, teológica e de transcendência, enfrentando as formas de opressão e ódio permanente da sociedade. Daí Leopardi sustentar nos Pensieri: sofrem aqueles que não aprenderam a arte de simular, pois serão necessariamente vítimas da sociedade. Ele completa:

${ }^{713}$ LEOPARDI, Giacomo. Pensieri, aforismo $28^{\circ}$, a cura di Antonio Prete, p. 67: "Nè legge nè forza alcuna, nè progresso di filosofia nè di civiltà potendo impedire che uomo nato 0 da nascere non sai o degli uni o degli altri, resta che chi può eleggere, elegga. Vero è che non tutti possono, nè sempre".

714 LEOPARDI, Giacomo. Pensieri, aforismo 2o, a cura di Antonio Prete, p. 34: "veramente grandi, ai quali non sai mancato il padre nella prima età".

${ }^{715}$ Cf. LEOPARDI, Giacomo. Pensieri, aforismo 2º, a cura di Antonio Prete, p. 34.

${ }^{716}$ Cf. LEOPARDI, Giacomo. Pensieri, aforismo 2o, a cura di Antonio Prete, p. 35.

${ }^{717}$ Cf. CASERTA, Ernesto G. L'ultimo Leopardi: pensiero e poesia, p. 65. 
Existem algumas poucas pessoas no mundo, condenadas a não ser bem sucedidas com os homens em qualquer coisa, em razão de que, não por inexperiência, nem por pouco conhecimento da vida social, mas por uma natureza imutável delas, não sabem deixar certa simplicidade de modos, sem aquelas aparências e de não sei que fingido e artificioso, que todos os outros, também sem nada aperceber, e também os néscios, usam e têm sempre nos modos deles, e que está neles e para eles mesmos dificilmente de distinguir do natural ${ }^{718}$.

Se tais indivíduos não são experientes nessa arte, isso não se deve, no entender de Leopardi, a uma bondade inata deles, mas à incapacidade inata de aprender a arte maquiavélica. Leopardi orienta que, em vez de rivalizar com os patifes, melhor fariam adaptar-se à própria sorte sem dissimular a franqueza natural, uma vez que seria inútil e improdutivo, uma via contrária de favorecer a afetação de outros ${ }^{719}$.

Para Leopardi, a vida é "uma representação cênica [que]se verifica, sobretudo nisso, que o mundo fala com muita constância de uma maneira e opera, com muita constância, de uma outra"720. Essa "comédia" [commedia] que todos hoje representam, por causa do modo como todos falam, quase como se não houvessem espectadores, pois todos recitam, só engana a crianças e estúpidos. No seu entender, seria tarefa digna para o seu século tornar a vida "uma ação não simulada, mas verdadeira, e conciliar pela primeira vez no mundo a famosa discórdia entre os ditos e os fatos"721. Tal tarefa seria possível, pois Leopardi reconhece a imutabilidade dos fatos, e assim evitando 0 esforço dos homens de buscarem coisas impossíveis. Para tanto, ele propõe

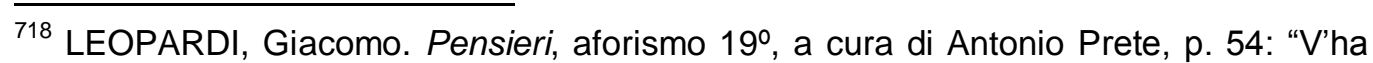
alcune poche persone al mondo, condannate a riuscir male cogli uomini in ogni cosa, a cagione che, non per inesperienza nè per poca cognizione della vita sociale, ma per una loro natura immutabile, non sanno lasciare una certa semplicità di modi, privi di quelle apparenze e di non so che mentito ed artifiziato, che tutti gli altri, anche senza punto avvedersene, ed anche gli sciocchi, usano ed hanno sempre nei modi loro, e che è in loro e ad essi medesimi malagevolissimo a distinguere dal naturale".

${ }^{719}$ Cf. LEOPARDI, Giacomo. Pensieri, aforismo 19º, a cura di Antonio Prete, pp. 54-55.

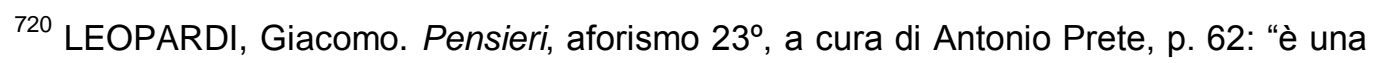
rappresentazione scenica, si verifica sopratutto in questo, che il mondo parla costantissimamente in una maneira, ed opera costantissimamente in un'altra".

721 Ibidem: "un'azione non simulata ma vera, e di conciliare per la prima volta al mondo la famosa discórdia tra i detti e i fatti". 
como único meio e muito fácil, ou seja, "mudar os ditos e chamar uma vez as coisas pelos nomes"722.

O maquiavelismo social não é um produto apenas da natureza ou de suas leis, mas também é fruto do homem, pois resulta da deformação do pensamento e da vontade, ou seja, do universo cultural e institucional: igreja, governo, família, educação. Por isso Leopardi reportando-se às nações e à Itália, em particular, escreve: "A educação que recebem, especialmente na Itália aqueles que são educados (na verdade, não são muitos) é uma traíção formal ordenada pela fraqueza contra a força, da velhice contra a juventude" ${ }^{\text {"23 }}$. Isso porque 0 interesse pela tranquilidade comum, doméstica e pública se revela como algo contrário aos feitos dos jovens. Por conseguinte, mesmo a boa educação consiste em grande parte em enganar os alunos. Segundo Leopardi, em todos os tempos a velhice conspirou "contra a juventude, porque em todos os tempos foi próprio dos homens a vileza de condenar e perseguir em outros aqueles bens que eles mais desejariam para si mesmos"724.

As observações presentes nos Pensieri revelam uma inteligência mundana de seu autor e, ao mesmo tempo, uma prática no trato da vida social, constituindo assim a base de certa sabedoria ante as coisas do mundo, da sociedade. Trata-se de uma análise também da vida possível no século tão odiado por Leopardi, na qual revela também um olhar mais imediato daquilo que ocorre na sociedade moderna de sua época, completando a sua diagnose do mundo moderno. Sobre a sociedade, ele escreve:

A sociedade dos homens é semelhante aos fluídos; cada molécula das quais, ou glóbulos, comprimindo fortemente os vizinhos de baixo e de cima e de todos os lados, e por meio daqueles os distantes, e sendo comprimido de novo na mesma maneira, se em qualquer lugar o resistir e repelir diminui, não passa

722 Ibidem: "mutare i detti, e chiamare una volta le cose coi nomi loro".

${ }^{723}$ LEOPARDI, Giacomo. Pensieri, aforismo 104을 a cura di Antonio Prete, p.155: "L'educazione che ricevono, specialmente in Italia, quelli che sono educati (che a dir vero, non sono molti), è un formale tradimento ordinato dalla debolezza contro la forza, dalla vecchiezza contro la giuventù".

${ }^{724}$ Ibidem: "contro la giovinezza, perchè in tutti i tempi fu propria degli uomini la viltà di condannare e perseguitare in altri quei beni che essi più desidererebbero a se medesimi”. 
um instante que convergindo acolá com fúria, aquele lugar é ocupado por novos glóbulos ${ }^{725}$.

Tal compreensão acurada da natureza da sociedade, de modo tão perspicaz, pressupõe não só uma segurança de percepção, mas também uma experiência prática e inteligência analista.

As análises presentes nos Pensieri revelam também aquela astúcia que Leopardi comenta em um dos Pensieri, ou seja: "A astúcia, a qual pertence ao engenho, é usada muito mais vezes para suprir a escassez desse engenho, e

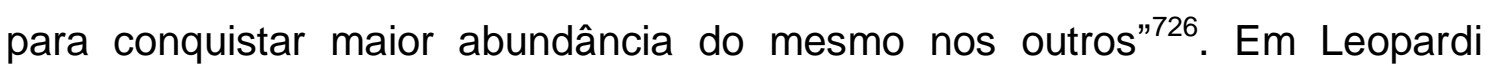
convergem, porém, engenho, astúcia, cooperando com a ironia e com o sarcasmo moral e dessa cooperação resulta semelhante observação:

O mundo naquelas coisas que, de outra forma, Ihe conviria admirar, rir; e reprova, como a raposa de Esôpo, aquelas que inveja [...]. Um hábito generoso, uma ação heroica deveria ser admirada: mas os homens se admirassem, especialmente nos iguais, acreditar-se-iam humilhados; e por isso, em vez de amar, riem. Essa coisa vai tão longe, que na vida comum é preciso dissimular com mais diligência a nobreza do operar, que a vileza: porque a vileza é de todos, e por isso pelo menos é perdoada, a nobreza é contra o hábito, e parece que indique presunção, ou que para si peça elogios: a qual o público e, sobretudo, os conhecidos, não amam dar com sinceridade ${ }^{727}$.

${ }^{725}$ LEOPARDI, Giacomo. Pensieri, aforismo $101^{\circ}$, a cura di Antonio Prete, p. 152: "La società degli uomini è símile ai fluidi; ogni molecola dei quali, o globetto, premendo fortemente $\mathrm{i}$ vicini di sotto e di sopra e da tutti i lati, e per mezzo di quelli i lontani, ed essendo ripremuto nella stessa guis, se in qualche posto il resistere e il risospingere diventa minore, non passa un attimo, che, concorrendo verso colà a fúria tutta la mole del fluido, quel posto è occupato da globetti nuovi".

726 LeOPARDI, Giacomo. Pensieri, aforismo 105으, a cura di Antonio Prete, p. 157: "L'astuzia, la quale appartiene all'ingegno, è usata moltissime volte per supplire la scarsità di esso ingegno, e per vincere maggior copia del medesimo in altri".

${ }^{727}$ LEOPARDI, Giacomo. Pensieri, aforismo $106^{\circ}$, a cura di Antonio Prete, p. 158: "II mondo a quelle cose che altrimenti gli converrebbe ammirare ride; e biasima, come la volpe d'Esopo, quelle che invidia. Una gran passione d'amore, con grandi consolazioni di grandi travagli, è invidiata universalmente; e perciò biasimata con più calore. Uma consuetudine generosa, un'azione eroica, dovrebb'essere ammirata: ma gli uomini se ammirassero, specialmente negli uguali, si crederebbero umiliati; e perciò, in cambio d'ammirare, ridono. Questa cosa va tant'oltre, che nella vita comune è necessário dissimulare con più diligenza la nobiltà dell'operare, che la viltà: perchè la viltà è di tutti, e però almeno è perdonata; la nobiltà è contro l'usanza, e pare che indichi presunzione, o che da se richiegga lode; la quale il pubblico, e massime i conoscenti, non amano di dare con sincerità". 
Leopardi examina a natureza humana nos contextos mais diversos e contingentes, descrevendo e destacando os motivos e razão dos comportamentos humanos, fruto de uma sabedoria que ele aconselha aos homens de "não confiar senão nas suas forças", ou seja, ensina o que se deve fazer para vencer a batalha contra o mundo e a sociedade. Trata-se de "uma íntima fusão entre sabedoria prática e moral de uma parte, e não só de uma iluminada percepção do verdadeiro caráter da sociedade, mas também da mesma razão prática de outra"728. É com base nessa mesma sabedoria, reveladora de certa intensidade na percepção do mundo, da sociedade, da alma e natureza humana que the orienta dizer nos Pensieri: "Nenhum sinal maior de ser pouco filósofo e pouco sábio, que querer sábia e filosófica toda a vida"729.

${ }^{728}$ Cf. SINGH, G. Leopardi filosofo anti-filosofo, pp. 151-152.

729 LEOPARDI, Giacomo. Pensieri, aforismo 27ํㅡ, a cura di Antonio Prete, p. 66: "Nessun maggior segno d'essere poco filosofo e poco savio, che volere savia e filosófica tutta la vita". 


\section{CONCLUSÃO}

II mondo alla fine è sempre in istato di freddo, e le verità scoperte nel calore, per grandi che siano, non mettono radici nella mente umana, finché non sono sanzionate dal placido progresso della fredda ragione, arrivata che sia dopo lungo tempo a quel segno.

Giacomo Leopardi. Zibaldone di pensieri

À guisa de conclusão, deve-se retornar aqui à indagação sobre um Leopardi "filósofo da sociedade" e um Leopardi "metafísico", ou seja, um apenas? Leopardi reconhece que um filósofo ou um homem reflexivo com o hábito da vida social não podem, a menos que seja quase um filósofo de sociedade, psicólogo ou político, após certa experiência da solidão, se tornar um metafísico. É inegável que o pensamento de Leopardi pressupõe uma experiência constante com os homens e uma intensa observação de seus comportamentos na vida social. Nessas atentas observações, Leopardi pôde compreender os anseios e sofrimentos cotidianos dos homens. Daí se poder dizer com Leopardi de se tratar de um amor, e não a repulsa em relação ao trato com o outro.

Nessa experiência se revela também a sua compreensão das mudanças ocorridas no presente, após o processo de modernização e de espiritualização das coisas e do homem. Nesse momento a sua análise e sabedoria concreta articulam certos elementos interpretados com base naquele trato cotidiano, elementos relativos a aspectos da individualidade e daquilo que constitui a ideia de natureza humana. Nessa compreensão certas disposições, constituidoras da natureza humana, se entrelaçam com a compreensão da mudança cultural e dos costumes no mundo moderno em que, não obstante essas transformações, algo permanece imutável e constante.

A natureza humana é única no tempo, e segue a leis férreas de uma natureza constante e eterna que na continuidade da reflexão de Leopardi revela-se matrigna, pois indiferente aos anseios e sofrimentos do gênero humano. Se as mudanças ocorridas no domínio da história e da cultura, não trouxeram, não obstante as falsas promessas de melhoramento com 0 
progresso da história, um alentamento ante o abandono e solidão do homem na sua vida, seja como indivíduo seja como espécie. A natureza segue o seu curso independente e indiferente ao projeto postulado pelos doutos e políticos dessa época. Por sua vez, a história segue o seu curso e não realiza as promessas e os ideais buscados pela humanidade no seu percurso.

Leopardi compreende, seja o curso da natureza seja aquele da história. Daquele da natureza ele tem a certeza de que a natureza não realizará o que prometera, pois o que revelou foi a impossibilidade de felicidade, de perfectibilidade, de melhoramento e salvação humana. Quanto à história, Leopardi reconhece a nulidade de todas as coisas e a fragilidade de todos os ideais que porventura indivíduos, sociedades e povos venham a estabelecer. Por conseguinte, a história não constitui para Leopardi, não obstante as mudanças e transformações ocorridas nos costumes e na cultura, um solo seguro e de certezas em relação aquilo que a natureza humana solicita.

Por isso o homem, o poeta e o filósofo Leopardi observa a vida e aprende a constituir uma sageza concreta inspirada na prática e no trato imediato com a contingência dos indivíduos. Ele realiza o seu diagnóstico, de um lado, dos sofrimentos cotidianos dos homens, de outro, da mudança da configuração da cultura e da sociedade, mas não vislumbra e tampouco constitui para si a esperança ou certeza de que o projeto humano e o projeto histórico possam se encontrar e se unir no sentido de modificar o imodificável, transformar aquilo que não é transformável,I no sentido e ideais dos homens, a saber, a natureza.

A natureza seguirá sempre o seu curso e Leopardi como pastor errante da Ásia sabe de que a lua estará sempre a observar eternamente os homens sem mudar o seu percurso. Daí se compreender que não há no pensamento de Leopardi um pessimismo retórico e tampouco o primado de uma orientação teórica e filosófica voltada exclusivamente para simplesmente justifica-lo. O seu pessimismo é antes de qualquer coisa a sua própria experiência de indivíduo e de homem, pois se entrelaça e se encarna a sua própria existência. Portanto, tal pessimismo não advém de sua leitura e de fontes eruditas, mas constitui a sua própria existência e experiência trágica da finitude. A busca e a prática da 
erudição, apenas revelam e justificam aquilo que decorre da busca do indivíduo, do poeta, do filósofo Leopardi.

Por isso se evita aqui certa nomenclatura teórica para definir a sua orientação de pensamento, seja a de progressista, de conservador, de liberal, pois todas elas não ajudam uma compreensão, no sentido amplo, daquilo que se constitui como pensamento leopardiano. Ademais, como crítico da Modernidade e daquilo que se transformou o saber, pode-se sustentar que a Filosofia ou a Ciência não são o seu ideal. O seu saber não é aquele constituído por certa tradição epistemológica ou como busca da verdade no sentido do primado das filosofias. Trata-se de um saber útil à vida, pois se constitui na sua experiência, tanto na relação com a vida quanto na relação com poetas, filólogos, historiadores, retóricos, filósofos, ou seja, como exercício de existência e de erudição.

Por conseguinte, encerrar Leopardi com base em primados conceituais rígidos, dificulta uma compreensão de que o seu "sistema", seja o da natureza seja o do homem, não valem, em primeiro lugar, como simples criação intelectual, pois são expressões, antes de qualquer coisa, da sua busca de compreensão de si e do mundo, a fim de constituir, de início, uma resposta às suas várias indagações como indivíduo comum, ou seja, como compreensão de sentido e de experiência autobiográfica.

Portanto, responder à questão do filósofo de sociedade e do metafísico significa aqui pressupor a sua intenção como sábio e como homem, pois no seu pensamento se entrelaçam, quer as grandes questões metafísicas que dizem respeito à natureza humana e ao mundo, quer aquelas que decorrem da sua compreensão da realidade contingente e de sua interpretação da aparência dos acontecimentos e da caducidade das coisas. Daí se poder dizer que ao lado do pensador que realiza uma diagnose da vida social e de suas mudanças, a presença também de preocupações e questões que dizem respeito à existência humana e a busca de revelar os mistérios pertencentes a certo desconhecido e não apreendido.

Se enquanto Leopardi observa as mudanças ocorridas na vida social e aquilo que se apresenta no imediato da sociedade, solicita compreender as 
suas causas e permanecer atento às ruínas provocadas por essas mudanças, na solidão do pensador, ou seja, daquele que se retira num instante na busca de certas causas que não se encontram na aparência imediata, cabe o indagar metafísico daquilo que certos saberes ou certas orientações filosóficas deixam escapar e não compreender. Nesse sentido, o Leopardi do Discorso de 1824 não se esgota no filósofo de sociedade, pois ao lado da análise dos costumes e da società stretta se apresenta também a strage delle illusioni, ou seja, a ruína de ideais constituidores de sentido que a natureza e a imaginação dispuseram para os homens a fim de se conservarem.

Por isso, o filósofo de sociedade que realiza o seu diagnóstico das aparências manifestas no convívio civil é solicitado para compreender o sentido mais profundo que envolve a destruição das ilusões e o fim do ethos antigo. Para tanto não valem os novos saberes oriundos das conquistas modernas, seja a estatística e a economia política, pois para Leopardi são insuficientes como conhecimento na medida em que ele como poeta expressa em sua atividade a necessidade de uma compreensão mais profunda daquilo que afeta a natureza humana. Nesse momento o metafísico sem sistema e sem doutrina se lança na indagação sobre o homem.

A grande questão para Leopardi é a infelicidade humana, pois ela permanece com as próprias leis férreas da natura matrigna. Por isso a sua filosofia disperata exprime, antes de qualquer coisa, o sentido da impossibilidade da felicidade humana e da impossibilidade de qualquer ideal político, e de outra sociedade, poder oferecer e modificar o curso da própria natureza que não se dobra aos ideais e projetos humanos. Portanto, Leopardi não postula uma filosofia que ensine a buscar certos ideais que a própria natureza já revelou a falsidade e fragilidade deles, impedindo que qualquer saber ou ideal prático possa se opor ao determinismo natural e quebrar a ordem das coisas. 


\section{REFERÊNCIAS BIBLIOGRÁFICAS}

\section{Edições das obras de Giacomo Leopardi}

LEOPARDI, G. Dei costumi degl'italiani (org.) Augusto Placanica. Venezia: Marsilio, 1992 (2ª ed.).

LEOPARDI, G. Discorso sopra lo stato presente dei costumi degl'italiani [1824]. (orgs.) Mario Andrea Rigoni, Marco Dondero e Roberto Melchiori. Milano: BUR, 2006.

LEOPARDI, G. Epistolario in: Tutte le poesie, tutte le prose e lo Zibaldone. Roma: Newton\&Compton, 1997.

LEOPARDI, G. Epistolario, in: Tutte le poesie e tutte le prose e lo Zibaldone. Roma: Newton\&Compton. 2010 (2 $2^{\mathrm{a}} \mathrm{ed}$.).

Napoli: Guida,

LEOPARDI, G. Frammento sul suicidio, in: Operette morali [1824].

LEOPARDI, G. La vita e le lettere [1810-1835]. Milano: Garzanti, 1983.

LEOPARDI, G. Memorie e disegni letterari, in: Tutte le poesie e tutte le prose e lo Zibaldone. Roma: Newton\&Compton. 2010 ( $2^{\mathrm{a}} \mathrm{ed}$.). Guida, 1998.

LEOPARDI, G. Operette morali, a cura di Cesare Galimberti, Napoli:

LEOPARDI, G. Zibaldone di pensieri, in: Tutte le poesie, tutte le prose e lo Zibaldone. Roma: Newton\&Compton. 2010 (2 $2^{\mathrm{a}} \mathrm{ed}$.).

LEOPARDI, G. Tutti gli scritti. Inediti rari e editi [1809-1810]. Milano: Bompiani, 1993.

.Tutte le poesie e tutte le prose. (orgs.) Lucio Felici e Emanuele Trevi. Roma: Newton\&Compton. 1997.

. Tutte le poesie e tutte le prose e lo Zibaldone. (orgs.) Lucio Felici e Emanuele Trevi. Roma: Newton\&Compton. 2010.

. Canti [1835], in: Tutte le poesie, tutte le prose e lo Zibaldone.

Roma: Newton\&Compton, 2010.

. Canti [1835], a cura di Ugo Dotti, Milano: Feltrinelli, 2006 (5ª ed.). . (org.) Antonio Prete. Pensieri [1845]. Milano: Feltrinelli, 2005 ( $\left.2^{\mathrm{a}} \mathrm{ed}.\right)$.

. (org.) Cesare Galimberti. Pensieri [1845]. Milano: Adelphi, 2008 (9e․). 
. (orgs.) Lucio Felici e Emanuele Trevi. Pensieri [1830 - 1835].

In: Tutte le poesie, tutte le prose e lo Zibaldone. Roma: Newton\&Compton. 2010.

. (org.) Augusto Placanica. Discorso sopra lo stato presente dei costumi degl'italiani [1824]. Venezia, Marsilio, 1992 (2ed.).

. (org.) Mario Andrea Rigoni. Discorso sopra lo stato presente dei costumi degl'italiani [1824], Milano, BUR, 2006.

. (orgs.) Lucio Felici e Emanuele Trevi. Discorso sopra lo stato presente dei costumi degl'italiani [1824]. In: Tutte le poesie e tutte le prose e lo Zibaldone. Roma: Newton\&Compton, 2010.

. (orgs.) Salvatore Veca e Maurizio Moncagatta. Discorso sopra lo stato presente dei costumi degl'italiani [1824]. Milano, Feltrinelli, 2008 (3e.ed.).

. Discorso di un italiano itorno alla poesia romântica [1818]. Con una antologia di testimonianze sul Romanticismo. Saggio introduttivo di Francesco Flora, a cura di Ettore Mazzali, Persiceto: Cappelli Editore, 1970.

. Discorso di un italiano itorno alla poesia romântica [1818], introduzione e commento di Vittorio Gatto, Roma: Archivio Guido Izzi, 1999.

. Discorso di un italiano itorno alla poesia romântica [1818], a cura di Rosita Copioli, Milano: BUR, 2007.

. Discorso di un italiano itorno alla poesia romântica [1818]. In:

Tutte le poesie, tutte le prose e lo Zibaldone. Roma: Newton\&Compton. 2010. . La vita e le lettere [1810 - 1835]. Milano: Garzanti, 1983. . Epistolario [1810-1835], in: Tutte le poesie, tutte le prose e lo Zibaldone. Roma: Newton\&Compton, 2010.

. Memorie e disegni letterari [1819 - 1834], in: Tutte le poesie, tutte le prose e lo Zibaldone. Roma: Newton\&Compton. 2010.

. Operette morali [1824-1834], in: Tutte le poesie e tutte le prose e lo Zibaldone. Roma: Newton\&Compton, 2010.

Napoli: Guida, 1998, (5ª ed.).

. Operette morali [1824-1834], a cura di Cesare Galimberti. 
. Zibaldone di pensieri [1817-1832], in: Tutte le poesie, tutte le prose e lo Zibaldone. Roma: Newton\&Compton, 2010.

. Zibaldone di pensieri in Cd-rom. Edizione critica a cura di Fiorenza Ceragioli e Monica Ballerini. Napoli: Zanichelli, 2009.

\section{Obras de Giacomo Leopardi}

. (org.) Antonio Prete. Pensieri [1830 - 1835]. Milano:

Feltrinelli, 2005 ( $2^{\mathrm{a}}$ ed.).

. (org.) Mario Andrea Rigoni. La strage delle illusioni. Pensieri sulla politica e sulla civiltà, Milano: Adelphi, 1993 (2 $2^{\mathrm{a}}$ ed.).

. (org.) Mario Andrea Rigoni. Discorso sopra lo stato presente dei costumi degl'italiani [1824], Milano, BUR, 2006.

. Canti [1835], a cura di Ugo Dotti, Milano: Feltrinelli, 2006 (5 ed.).

. Discorso di un italiano itorno alla poesia romântica [1818], introduzione e commento di Vittorio Gatto, Roma: Archivio Guido Izzi, 1999.

. Epistolario [1810-1835], in: Tutte le poesie, tutte le prose e lo Zibaldone. Roma: Newton\&Compton, 2010.

. Memorie e disegni letterari [1819 - 1834], in: Tutte le poesie, tutte le prose e lo Zibaldone. Roma: Newton\&Compton. 2010. Guida, $\overline{1998,\left(5^{a} \mathrm{e}\right.}$.).

. Operette morali [1824-1834], Cesare Galimberti. Napoli: . Zibaldone di pensieri [1817-1832], in: Tutte le poesie, tutte le prose e lo Zibaldone. Roma: Newton\&Compton, 2010.

. Zibaldone di pensieri in Cd-rom. Edizione critica a cura di Fiorenza Ceragioli e Monica Ballerini. Napoli: Zanichelli, 2009.

\section{Traduções das obras de Giacomo Leopardi em língua portuguesa}

LEOPARDI, G. Correspondência [1816 - 1837], in: Poesia e Prosa, trad. br. Affonso Féliz de Souza, Alexei Bueno et al., Rio de Janeiro, Aguilar, 1996. . Cantos [1816-1836], in: Poesia e Prosa, trad. br. Affonso Féliz de Souza, Alexei Bueno et al., Rio de Janeiro, Aguilar, 1996. 
- Carta aos senhores compiladores da Biblioteca italiana [1816], in: Poesia e Prosa, trad. br. Affonso Féliz de Souza, Alexei Bueno et al., Rio de Janeiro, Aguilar, 1996.

. Seleção do Zibaldone [1820 - 1824], in: Poesia e Prosa, trad. br. Affonso Féliz de Souza, Alexei Bueno et al., Rio de Janeiro, Aguilar, 1996.

. Opúsculos morais [1824 - 1834], in: Poesia e Prosa, trad. br. Affonso Féliz de Souza, Alexei Bueno et al., Rio de Janeiro, Aguilar, 1996.

. Discurso sobre o estado atual dos costumes dos italianos [1824], in: Poesia e Prosa, trad. br. Affonso Féliz de Souza, Alexei Bueno et al., Rio de Janeiro, Aguilar, 1996. . Pensamentos [1830 -1835], in: Poesia e Prosa, trad. br. Affonso Féliz de Souza, Alexei Bueno et al., Rio de Janeiro, Aguilar, 1996.

\section{Obras sobre Giacomo Leopardi}

BINNI, W. Lettura delle Operette Morali. Genova: Marietti 1820, 1997. . La nuova poetica leopardiana [1947]. Firenze: Sansoni, 1984 (4ed.).

. La protesta di Leopadi [1973]. Milano: Sansoni, 2000.

BIRAL, B. La posizione storica di Giacomo Leopadi [1959]. Torino, Einaudi, 1997 (5eㄹ.).

BISCUSO, M. , GALLO, F. Leopardi antitaliano, Roma, Manif, 1999.

BLASUCCI, L. I tempi dei "Canti". Nuovi studi leopardiani. Torino: Einaudi, 1996.

CACCIARI, M. Magis Amicus Leopardi. Due saggi. Caserta: Saletta del'Uva, 2005.

CACCIATORE, G. (org.). Le Operette morali di Leopardi. Assisi, Cittadela Editrice, 2000.

CAMPAILLA, S. La vocazione di Tristano. Storia interiore delle "Operette morali". Bologna, Pàtron Editore, 1996. 
CASSANO, F. Oltre il nulla. Studio su Giacomo Leopardi. Roma-Bari: Laterza\&Figli, 2003.

CECCHETTI, G. Sulle "Operette morali". Tre studi con un poscritto sull'elaborazione dei "Canti". Roma, Bulzoni, 1978.

CITATI, P. Leopardi. Milano: Arnoldo Mondadori, 2010.

CONSOLI, D. Leopardi: natura e società, Roma, Edizione Studium, 1977.

DA FILICAIA, C. G. Fuori Recanati io non sogno. Temi e percorsi di Leopardi epistolografo. Firenze, Le Lettere, 2006.

DAMIANI, R. All'apparir del vero. Vita di Giacomo Leopardi. Milano: Mondadori, 2002.

D'INTINO, F. L'immagine della você. Leopardi, Platone e il libro morale. Venezia, Marsilio, 2009.

DOLFI, A. Le verità necessarie. Leopardi e lo "Zibaldone". Modena: Mucchi, 1995.

DONDERO, M. Leopardi e gli italiani. Ricerche sul "Discorso sopra lo stato presente dei costumi degl'italiani". Napoli, Liguori, 2000.

DOTTI, U. Lo sguardo sul mondo. Introduzione a Leopardi. Roma-Bari: Laterza, 1999.

FERRARIS, A. La vita imperfetta. Le Operette morali di Giacomo Leopardi. Genova, Marietti, 1991.

FERRUCCI, C. Leopardi filosofo e le ragioni della poesia. Venezia: Marsilio, 1987.

FIGURELLE, F. Lettura delle "Operette Morali" del 1824. Lezioni dell'anno accademico 1975-76. Napoli, De Simone editore, 1976.

FOSCHI, F., GARBUGLIA, R. Omaggio a Leopardi. Vols. I-II, Mestrino (Pd), Francisci Editore, 1987.

GATTI, P. Esposizione del sistema filosofico di Giacomo Leopardi: Saggio sullo Zibaldone. Vols. I-II, Firenze: Le Monnier, 1906.

GATTI, P. L'unità del pensiero leopardiano: saggio critico-polemico. Napoli: Editore: Dott. Gennaro Giannini, 1921.

GHIDETTI, E. (org.), Dizionario delle idee. L'uomo, la natura, la società, la storia. Roma: Riuniti, 1998.

GUERINI, A. Gênero e tradução no Zibaldone de Leopardi. São Paulo: Edusp; Florianópolis: UFSC/PGET, 2007.

JONARD. N; BIRAL. B; CELLERINO. L; PIRODDA. G. I/ caso Leopardi. Palermo: Palumbo editore, 1974.

KOOPMANN, S. Studi sulla recondita presenza di Rousseau nell'opera di Giacomo Leopardi. Trad. it. Valentina Di Rosa, Cosenza: Memoria, 2003.

LUPORINI, C. Leopardi progressivo [1947]. Roma: Riuniti, 2006. 
NADDEI CARBONARA, M. L'eterno e il tempo in Giacomo Leopardi poeta filosofo. Napoli: Libreria Scientifica, 1973.

PLACANICA, Augusto. Leopardi e il Mezzogiorno del mondo. Napoli: Avagliano, 1998.

POLIZZI, G. (org.). Leopardi e la Filosofia. Firenze: Polistampa, 2001.

POLIZZI, G. Leopardi e "le ragioni della verità". Scienze e filosofia della natura negli scritti leopardiani. Roma: Carocci, 2003.

PORENA, M. II pessimismo di Giacomo Leopardi [1923], in: Scritti leopardiani. Bologna: Zanichelli, 1959.

PRETE, A. (org.). Sulle Operette Morali. Sette studi. San Cesario di Lecce, Manni, 2008.

RAVASI, S. Leopardi et Mme de Staël [1910]. Paris: Centro Nazionale di Studi Leopardiani-Fondazione Garzanti, 1999.

RENZI, G. Lo scetticismo estetico di Leopardi. Ferrara: Gallio, 1990. 1990 ( $2^{\mathrm{a}} \mathrm{e}$ ed.).

RIGONI, M. A. Saggi sul pensiero leopardiano, Napoli: Liguori editore, . Il pensiero di Leopardi, Torino: Aragno, 2010. 1999.

RUSSO, F. Leopardi político o della felicita impossibile. Roma: Bulzoni,

SANSONE, M. Storicità e letteratura: da Machiavelli a Leopardi, Napoli, Edizioni Scientifiche Italiane, 1997.

SAPEGNO, N. Leopardi: lezioni e saggi. Torino: Nino Aragno, 2006.

SAVARESE, G. L'eremita osservatore. Saggio sui "Paralipomeni" e altri studi su Leopardi. Roma, Bulzoni, 1995.

SERBAN, N. Leopardi et la France. Essai de littérature comparée. Paris: Librairie ancienne honoré champion, 1913.

SINGH, G. Leopardi filosofo anti-filosofo, Pisa-Roma, Istituti editoriali i poligrafici internazionali, 1997.

SOLMI, S. Studi leopardiani: note su autori classici italiani e stranieri. Vol. II, Milano: Adelphi, 1987.

SPAGGIARI, W. L'eremita degli appennini: Leopardi e altri studi di primo Ottocento. Milano: Unicopli, 2000. 1974.

STACCCHINI GAZZOLA, V. Leopardi politico. Bari, De Donato editore,

TELLINI, G. Leopardi. Roma, Salerno editrice, 2001. 
TILGHER, A. La filosofia di Leopardi e studi leopardiani. Bologna: Massimiliano Boni, 1979.

TIMPANARO, S. Classicismo e illuminismo nell'ottocento italiano: testo critico con aggiunta di saggi e annotazioni autografe. Firenze: Le Lettere, 2011.

TIMPANARO, S. La filologia di Giacomo Leopardi. Roma-Bari: Laterza\&Figli, 2008 (4e․ .).

TONELLI, L. Leopardi. Milano: Cultura contemporânea, 1943.

TRENTI, L., ROSCETTI, F. Leopardi e Roma. Roma, Editore Colombo, 1991.

ZUMBINI, B. Studi sul Leopardi, vol. I, Firenze: G. Barbèra, 1902; vol. II, Firenze: G. Barbèra, 1904.

\section{Artigos em Revistas sobre Leopardi}

DOLFI, A. Leopardi e il pensar filosofico di Madame de Staël. In: Leopardi e la cultura europea. Atti del convegno internazionale dell'Università di Lovanio (Lovanio - 10-12 dicembre, 1987), Roma: Bulzoni-Leuven University press, 1989.

DOTTI, Ugo. La radiografia leopardiana della società politica e intellettuale italiana. In: Lo Zibaldone cento anni dopo. Composizione,edizioni, temi. Atti del X Convegno Internazionale di studi leopardiani. Vol II. Set/1998, Recanati-Italia, Centro Nazioanle di Studi Leopardiani (CNSL), Firenze: OLSCHKI Editore, 2001, pp. 673-678.

FELICE, L. Meridionali, meridionalità, meridio. In: Lo Zibaldone cento anni dopo. Composizione,edizioni, temi. Atti del X Convegno Internazionale di studi leopardiani. Vol II. Set/1998, Recanati-Italia, Centro Nazioanle di Studi Leopardiani (CNSL), Firenze: OLSCHKI Editore, 2001.

LENTZEN, M. I tedeschi e la Germania nello "Zibaldone" di Giacomo Leopardi. In: II pensiero storico e politico di Giacomo Leopardi. Atti del VI Convegno Internazionale di studi leopardiani. Vol II. Set/1984, Recanati-Italia, Centro Nazioanle di Studi Leopardiani (CNSL), Firenze: OLSCHKI Editore, 1989.

MAZZALI, E. La società italiana contemporânea e il Leopardi. In: /I pensiero storico e politico di Giacomo Leopardi. Atti del VI Convegno Internazionale di studi leopardiani. Vol II. Set/1984, Recanati-Italia, Centro Nazioanle di Studi Leopardiani (CNSL), Firenze: OLSCHKI Editore, 1989, pp. 349-355.

MUÑIZ MUÑIZ, M.D.L.N. Sul concetto di decadenza storica in Leopardi. In: Il pensiero storico e político di Giacomo Leopardi. Atti del VI Convegno 
Internazionale di studi leopardiani. Vol II. Set/1984, Recanati-Italia, Centro Nazioanle di Studi Leopardiani (CNSL), Firenze: OLSCHKI Editore, 1989, pp. 375-390.

MUSAMARRA, C. Leopardi e i "fatti" della storia. In: Il pensiero storico e politico di Giacomo Leopardi. Atti del VI Convegno Internazionale di studi leopardiani. Vol II. Set/1984, Recanati-Italia, Centro Nazioanle di Studi Leopardiani (CNSL), Firenze: OLSCHKI Editore, 1989, pp. 391-397.

MUSARRA, F. Meccanismi satirici e ironici nel Discorso sopra lo stato presente dei costumi degl'italiani. In: II riso leopardiano. Comico, sátira, parodia. Atti del IX Convegno internazionale di studi leopardiani. Vol. I. Set/1995, Recanati-Italia, Centro Nazionale di Studi Leopardiani (CNSL), Firenze: OLSCHKI Editore, 1998, pp. 259-280.

PELLECCHIA, R. L'Italia nell'Epistolario. In: Il pensiero storico e político di Giacomo Leopardi. Atti del VI Convegno Internazionale di studi leopardiani. Vol II. Set/1984, Recanati-Italia, Centro Nazioanle di Studi Leopardiani (CNSL), Firenze: OLSCHKI Editore, 1989, pp. 447-454.

\section{Bibliografia de apoio}

BARETTI, G. Scritti. Torino: Einaudi, 1976.

CANFORA, D. Prima di Machiavelli. Politica e cultura in età umanistica. Roma-Bari: Laterza\&Figli, 2005. 2007.

CAPPELLI, G. L'umanesimo italiano da Petrarca a Valla. Roma: Carocci,

CASSANO, F. II pensiero meridiano. Roma-Bari: Laterza, 2011 (4ª ed.).

CHABOD, F. Scritti su Machiavelli. Torino: Einaudi, 1964. . L'idea di nazione. Roma-Bari: Laterza, 2010 (17 ${ }^{\mathrm{a}} \mathrm{ed}$.).

DE MONTAIGNE, M. Viaggio in Italia [1774]. Trad. it. Ettore Camesasca. Milano: BUR-Rizzoli, 2010 (3를.

DE RUGGIERO, M. G. La Napoli Gentile di Giambattista Vico: curiosità, storie e suggestioni. Napoli: Grimaldi, 2008.

DE STAËL, M. Corinne o L'Italia, Milano: Mondadori, 2010.

DENINA, C. Considerazioni di un italiano sull'talia. Torino: Aragno, 2005.

FERTONANI, R. Goethe, L'Italia e gli italiani. In: GOETHE, Johann W. Viaggio in Italia [1816-1817], Trad. it. Emilio Castellani, Milano: Mondadori, 2011. 
GARIN, E. Idade média e Renascimento [1973]. Trad. port. Isabel Teresa Santos et al., Lisboa: Editorial Estampa, 1994. Laterza\&Figli, 2010.

. La cultura del Rinascimento. Profilo storico. Roma-Bari: . Machiavelli fra politica e storia. Torino: Einaudi, 1993.

GILBERT, F. Machiavelli e Guicciardini. Pensiero politico e storiografia a Firenze nel Cinquecento [1965]. Trad. it. Franco Salvatorelli, Torino: Einaudi, 1970.

GOETHE, J. W. Viaggio in Italia [1816-1817]. Trad. it. Emilio Castellani, Milano: Mondadori, 2011.

GUICCIARDINI, F. Ricordi. Milano: Ugo Mursia, 1994.

HAZARD, P. La crisi della coscienza europea [1961]. Trad. it. a cura di Paolo Serini, Torino: UTET, 2007 (9를.).

JACOBELLI, J. Machiavelli e Guicciardini. Alle redici del realismo politico. Milano: Mursia, 1998.

KRAYE, J. Introducción al humanismo renacentista [1998]. trad. esp. Carlos Clavería, España: Cambridge University (Sucursal en España), 1998.

KRISTELLER, P. Tradição clássica e pensamento do Renascimento [1954]. Trad. port. Artur Mourão, Lisboa: Edições 70, 1995.

. Il pensiero e le arti nel Rinascimento [1954]. Trad. it. Maria Baiocchi, Roma: Donzelli editore, 2005 (2ª ed.).

LARIVAILLE, P. A Itália no tempo de Maquiavel. Trad. br. Jonatas Batista Neto. São Paulo: Companhia das Letras, 1988.

MACHIAVELLI, N. Discorsi sopra la prima Deca di Tito Livio [1531], in: Tutte le opere storiche, politiche e letterarie. 1998.

MARQUESE DI SADE, D-A-F. Viaggio in Italia. Trad. it. Giovanni Ferrara degli Uberti, Torino: Bollati Boringhieri, 1996.

MONTESQUIEU. C. O espírito das leis [1748]. Trad. br. Cristina Murachco. São Paulo: Martins Fontes, 2000 ( $2^{\stackrel{a}{ }} \mathrm{ed}$.). Laterza, $2008\left(2^{\underline{a}}\right.$ ed.).

Viaggio in Italia. Trad. it. Massimo Colessanti, Roma-Bari:

PONSETTO, A. L'umanesimo Rinascimentale e la nascita della Modernità. Tra autonomia dell'uomo, nuove forme di dominio e loro superamento. Padova: Università di Padova, 2011.

RAIMONDI, E. Letteratura e identità nazionale. Milano: Mondadori, 2000.

ROSA, A. Storia europea della letteratura italiana. II - Dalla decadenza al Risorgimento. Torino: Einaudi, 2009.

SALVATORELLI, L. II pensiero politico italiano: dal 1700 al 1870. Torino: Einaudi, 1941 (2 $2^{\underline{a}}$ ed.).

SASSO, G. Niccolò Machiavelli. II pensiero politico. Vol. I, Bologna: II Mulino, 1992. 
STENDHAL. Passeggiate romane. trad. it. Massimo Colesanti. Milano: Garzanti, 2009 (2⿺辶a $e d$.). Mondadori, 2011.

La Certosa di Parma. Trad. it. Stefano Agosti. Milano: Oscar

VANDER, F. De philosophia italica. Modernità e politica in Vico e Cuoco. Lecce: Pensa Multimedia, 2010.

VICO, G. De antiquíssima italorum sapientia [1710]. In: Opere filosofiche. Firenze: Sansoni, 1971. . Lettere, in: Opere, tomo I, Milano: Mondadori, 1990. . Principi di scienza nuova d'intorno alla comune natura delle nazione [1744], in: Opere, Tomo I, Milano: Armando Mondadori, 2001.

. Risposta del signor Giambattista Vico [1711]. In: Opere filosofiche, Firenze: Sansoni, 1971.

Firenze: Sansoni, 1971.

Risposta di Giambattista Vico [1712]. In: Opere filosofiche,

VISCARDI, A. Storia della letteratura italiana: dalle origini al Rinascimento. Milano: Nuova Accademia, 1960.

\section{Artigos e capítulos de livros}

. (ORG.) Giacomo Leopardi. La strage delle illusioni. Pensieri sulla politica e sulla civiltà. Milano, Adelphi, 1993 (2ª̃ed.).

"1813-'15. Filologia ed erudizione: primi schemi intellettuali", in: BELLUCCI, N. (org.) Walter Binni. Lezioni leopardiane, Firenze, La nuova Italia, 1998.

. "Leopardi e i costumi degli italiani", in: LEOPARDI, G. Discorso sopra lo stato presente dei costumi degl'italiani, Milano, BUR, 2006.

. "Leopardi, il mezzogiorno in idea e l'Italia", in: DELL'AQUILA, M. (org.), Ripensare Leopardi. Fasano (Br-Italia), Schena Editore, 1999.

ALFONSI, L. "La filologia del Leopardi e la letteratura latina", in: FOSCHI,F., GARBUGLIA, R. Omaggio a Leopardi, vol.II, Mestrino, Francisci editore, 1987, pp. 489-509.

BIRAL, B. La "posizione storica" di Leopardi. In: La posizione storica di Giacomo Leopardi. Torino: Einaudi, 1997. 
COLAIACOMO, C. "La filologia del 'moderno' di Giacomo Leopardi", in: Camera obscura. Studio di due canti leopardiani, Napoli, Liguori Editore, 1992, pp. 147-160.

DE STÄEL, M. Costumi e carattere degli Italiani. In: Corinna o L'Italia. Milano: Mondadori, 2010, (2ª ed.), pp. 135-361.

GALIMBERTI, C. Fanciulli e più che uomini, in: LEOPARDI, Giacomo. Pensieri. Milano: Adelphi, 2008.

GALIMBERTI, C. Un libro metafísico, in: Operette morali [18241834],(org.) Cesare Galimberti. Napoli: Guida, 1998, (5ed.).

Givone, S. Filosofia, poesia e mito in Vico e in Leopardi, in: Vattimo, G. (org.). Filosofia '95, Roma-Bari, Gius. Laterza\&Figli, 1996.

JONARD, N. Leopardi fra conservazione e progresso, in: JONARD. N; BIRAL. B; CELLERINO. L; PIRODDA. G. I/ caso Leopardi. Palermo: Palumbo editore, 1974.

MELCHIORI, R. Commento in: LEOPARDI, Giacomo. Discorso sopra lo stato presente dei costumi degl'italiani,

NEGRI, A. Rileggendo il leopardiano "Discorso sopra lo estato presente dei costumi degl'italiani, in: (org.). CACCIATORE, Giuseppe. Le operette morali di Giacomo Leopardi. Assisi: Cittadella, 2000.

NIETZSCHE, F. Intorno a Leopardi; OTTO, W. F. Leopardi e Nietzsche [1937], a cura di Cesare Galimberti. Genova: II Melangolo, 2000.

PACELLA, G. "La filologia di G. Leopardi tra Settecento e Ottocento", in: CNSL (Atti del II Convegno Internazionale di studi leopardiani), Firenze, Olschki, 1967, pp. 455-468.

PAVAN, M. "Leopardi e la storia ântica", in: CNSL (Atti del VI Convegno Internazionale di studi leopardiani), Firenze, Olschki, 1984, pp. 27-47.

PLACANICA, A. "Intruduzione", in: LEOPARDI, G. Discorso sopra 10 stato presente dei costumi degl'italiani [1824]. Venezia, Marsilio, 1992 (2ª ed.).

PLACANICA, A. Leopardi, o della modernità, in: LEOPARDI, G. Dei costumi degl'italiani. Venezia: Marsilio, 1992

PLACANICA, A. Leopardi. II Mezzogiorno in Idea e l'Italia. In: (org.). Michele Dell'Aquila. Ripensare Leopardi. Fasano (Br-Italia): Schena Editore, 1999.

POLIZZI, G. Filosofia delle circostanze e immagini della scienza nello Zibaldone, in: POLIZZI, G. (org.). Leopardi e la Filosofia. Firenze: Polistampa, 2001.

PONS, A. La rhétorique des manière au XVle siécle em Italie. In: FUMAROLI, Marc (org.). Histoire de la rhétorique dans l'Europe moderne: 1450-1950. Paris: Presses Universtaire de France, 1999. 
RAIMONDI, E. "Un poeta e la società: Giacomo Leopardi, Discorso sopra lo stato presente dei costumi degl'italiani". In: Leterattura e identità nazionale. Milano: Mondadori, 1998.

RIGONI, M. A. Introduzione, in: Giacomo Leopardi. Strage delle illusioni, pensieri sulla politica e sulla civiltà, Milano: Adelphi, 1993 ( $2^{\mathrm{a}}$ ed.).

RUSSO, F. I popoli europei visti da Leopardi. In: Leopardi político o della felicita impossibile. Roma: Bulzoni, 1999.

SANSONE, M. Leopardi e la filosofia del Settecento, in: Storicità e letteratura da Machiavelli a Leopardi. Milano: Edizioni Scientifiche italiane, 1997.

SINGH, G. "Il concetto dell'antichità in Leopardi", in: Leopardi filosofo anti-filosofo, Pisa-Roma, Istituti editoriali i poligrafici internazionali, 1997, pp. 126-141.

TATEO, F. "Leopardi e gli antichi", in: Dell'Aquila, M. (org.) Ripensare Leopardi, Fasano, Schena Editore, 1999, pp. 9-27.

VITALE, E. Saggio introduttivo. In: FICINO, M. Teologia platonica [1482]. Trad. it. Errico Vitale, Milano: Bompiani, 2011. 